\title{
TOXICIDADE DE ALUMÍNIO EM TRINTA GENÓTIPOS DE Panicum maximum Jacq. CULTIVADOS EM SOLUÇÃO NUTRITIVA
}

\author{
ANA APARECIDA DA SLVA \\ Bióloga
}

Orientador: Prof. Dr. FRANCISCO ANTONIO MONTEIRO

Tese apresentada à Escola Superior de Agricultura "Luiz de Queiroz", Universidade de São Paulo, para obtenção do título de Doutor em Agronomia, Área de Concentração: Solos e Nutrição de Plantas

PIRACICABA

Estado de São Paulo - Brasil

Dezembro - 1997 


\section{Dados Internacionais de Catalogação na Publicação (CIP)}

DIVISÃo DE BIBLIOTECA E DOCUMENTAÇĀO - Campus "Luiz de Queiroz"/USP

\section{Silva, Ana Aparecida da}

Toxicidade de aluminio em trinta genótipos de Panicum maximum jacq. cultivados em solução nutritiva / Ana Aparecida da Silva. - Piracicaba, 1997. 146 p. : il.

Tese (doutorado) - - Escola Superior de Agricultura Luiz de Queiroz, 1998. Bibliografia.

1. Capim coloniāo 2. Fitotoxidade 3. Genótipo vegetal 4. Graminea forrageira 5. Perfilho 6. Solução nutritiva 7. Raiz 8. Toleráncia ao alumínio I. Título 


\title{
TOXICIDADE DE ALUMÍNIO EM TRINTA GENÓTIPOS DE Panicum maximum Jacq. CULTIVADOS EM SOLUÇÃO NUTRITIVA
}

\author{
ANA APARECIDA DA SILVA \\ Bióloga
}

Orientador: Prof. Dr. FRANCISCO ANTONIO MONTEIRO

Tese apresentada à Escola Superior de Agricultura "Luiz de Queiroz", Universidade de São Paulo, para obtençào do título de Doutor em Agronomia, Área de Concentração: Solos e Nutrição de Plantas

PIRACICABA

Estado de São Paulo - Brasil

Dezembro - 1997 


\title{
TOXICIDADE DE ALUMÍNIO EM TRINTA GENÓTIPOS DE Panicum maximum Jacq. CULTIVADOS EM SOLUÇÃO NUTRITIVA
}

\author{
ANA APARECIDA DA SILVA
}

Tese apresentada à Escola Superior de Agricultura "Luiz de Queiroz", Universidade de São Paulo, para obtenção do título de Doutor em Agronomia, Área de Concentração: Solos e Nutrição de Plantas

PIRACICABA

Estado de São Paulo - Brasil

Dezembro - 1997 


\title{
TOXICIDADE DE ALUMÍNIO EM TRINTA GENÓTIPOS DE Panicum maximum Jacq. CULTIVADOS EM SOLUÇÃO NUTRITIVA
}

\author{
ANA APARECIDA DA SILVA
}

Aprovada em: 26.01 .1998

Comissão julgadora:

Prof. Dr. Francisco Antonio Monteiro

ESALQ/USP

Prof. Dr. Antonio Roque Dechen

ESALQ/USP

Prof. Dr. Jorge de Castro Kiehl

ESALQ/USP

Prof. Dr. Luís Roberto de Andrade Rodrigues

FCA/UNESP

Dr. Manuel Claudio da Motta Macedo

CNPGC/EMBRAPA

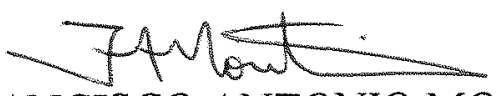

Prof. Dr. FRANCISCO ANTONIO MONTEIRO

Orientador 
Ao meu avô Geraldo Gouvêa "in memorian"

OFEREÇO

Ao Julio, por tudo

DEDICO 


\section{AGRADECIMENTOS}

Ao Professor Dr. Francisco Antonio Monteiro pela valiosa orientação, pelo estímulo, pela amizade e confiança.

Ao Professor Dr. Quirino Augusto de Camargo Carmello, pela amizade, auxilio e sugestões na condução dos experimentos.

Ao Professor Dr. Antonio Roque Dechen pela amizade e incentivo.

Ao Professor Dr. Celso Augusto Fessel Graner, do Departamento de Química do Instituto de Biociências da UNESP - Botucatu, pela estima e confiança.

À Coordenadoria de Aperfeiçoamento de Pessoal de Nivel Superior (CAPES) pela concessão da bolsa de estudo, sem a qual não seria possivel a realização desse Curso.

Ao Centro Nacional de Pesquisa de Gado de Corte (CNPGC-EMBRAPA) na pessoa da pesquisadora Liana Jank pela concessão de sementes dos acessos de Panicum maximum.

À Universidade de Taubaté (UNITAU) pela oportunidade proporcionada para realização desse Curso.

Às funcionárias do Laboratório de Nutrição Mineral de Plantas: Lurdes A. Dário de Gonzáles e Nivanda Maria de Moura pela colaboração nas análises laboratoriais.

Aos funcionários do Laboratório de Nutrição Mineral de Plantas: Edinéia C. S. Mondoni, Fernando Éder Ré, Lúcia Helena S. P. Forti e Mirtes V. Sesso pelo apoio.

Aos colegas de Curso Anacleto Ranulfo dos Santos, Beatriz Dias Côrrea, João Batista Rodrigues de Abreu e Waldssimiler Teixeira de Mattos, pelo auxilio durante a condução dos experimentos e pelo periodo agradável e produtivo de convivência .

Ao Julio Cesar Raposo de Almeida pelas sugestões durante a redação deste trabalho e pelo apoio sempre presente.

A Escola Superior de Agricultura "Luiz de Queiroz" - USP pelo oferecimento deste Curso de Pós-Graduação. 


\section{SUMÁRIO}

Página

RESUMO. vii

SUMMARY ix

1 INTRODUÇÃO 1

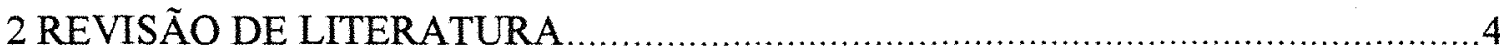

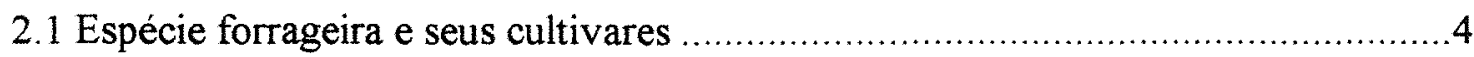

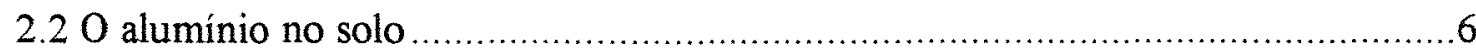

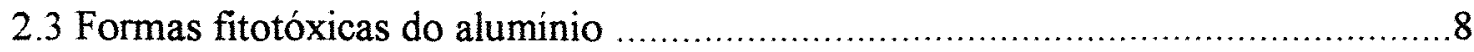

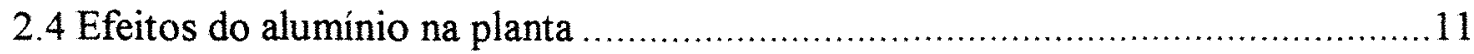

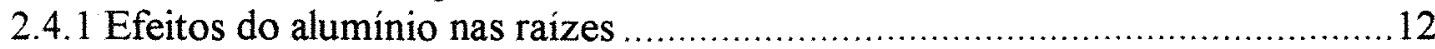

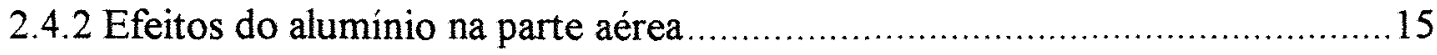

2.5 Respostas das gramíneas forrageiras ao alumínio.........................................17

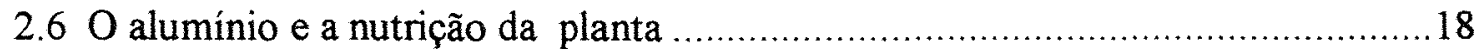

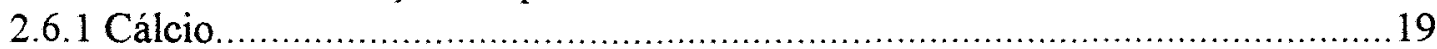

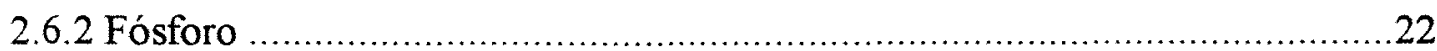

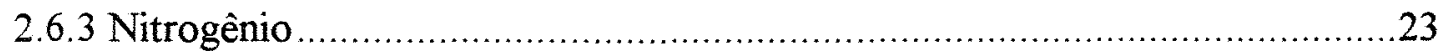

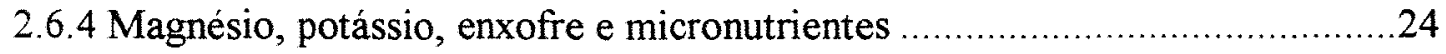

2.7 Influência do aluminio na atividade da redutase do nitrato..............................26

2.8 Influência do alumínio na atividade da fosfatase ácida ....................................27

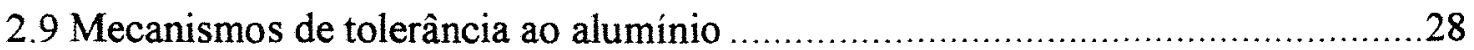

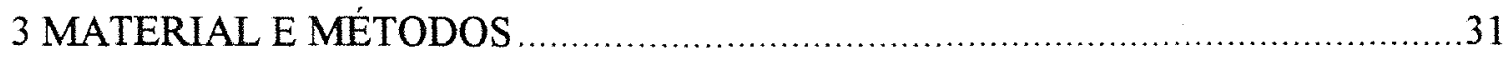

3.1 Seleção de genótipos de Panicum maximum para a tolerância ao alumínio ..........31

3.1.1 Genótipos de Panicum maximum e obtenção das mudas...............................32

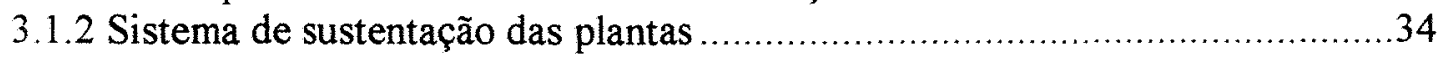

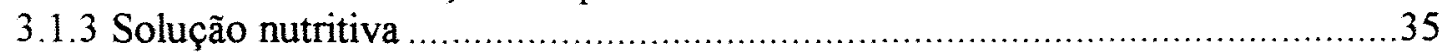

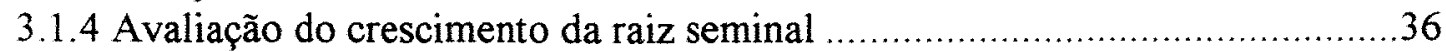

3.1.5 Delineamento experimental e análises estatísticas ...................................37 
3.2 Influência do alumínio em três genótipos de Panicum maximum com tolerância

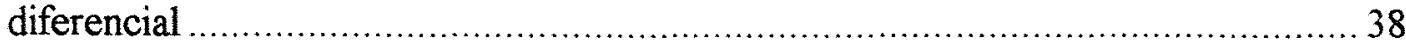

3.2.1 Obtenção das mudas e condução do experimento ....................................... 38

3.2.2 Determinações efetuadas no material vegetal............................................. 39

3.2.2.1 Perfilhamento, volume radicular, rendimento de matéria seca e

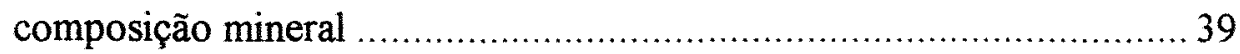

3.2.2.2 Atividade da redutase do nitrato .............................................. 40

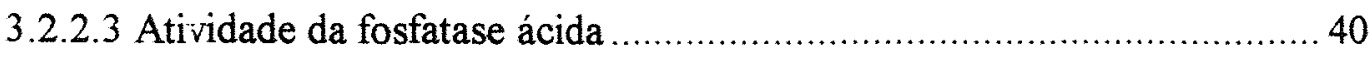

3.2.3 Delineamento experimental e análise estatística ...................................... 41

4 RESULTADOS E DISCUSSÃO

4.1 Experimentos de seleção de genótipos de Panicum maximum para a tolerância ao alumínio

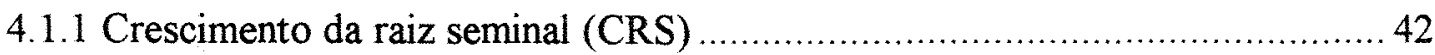

4.1.2 Comprimento relativo da raiz seminal (CRRS) .....................................5 50

4.1.3 Inibição do alongamento radicular induzida pelo alumínio (I) ......................56

4.1.4 Índice de tolerância ao alumínio (ITR-Al) .............................................59

4.2 Experimento com genótipos de Panicum maximum com tolerância diferencial ao alumínio

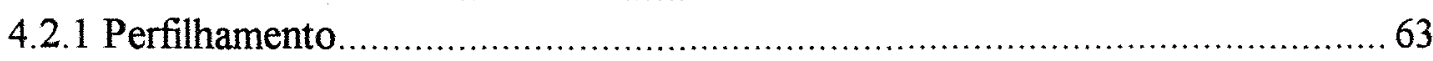

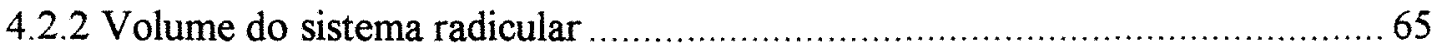

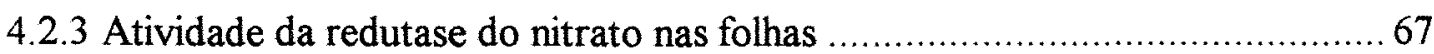

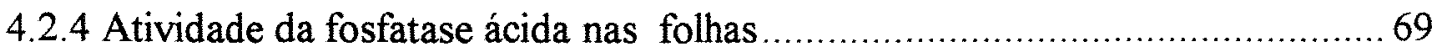

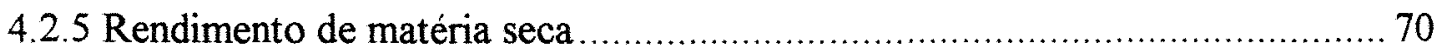

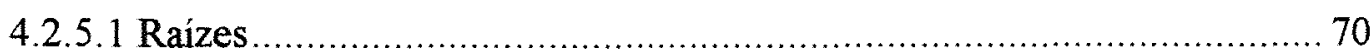

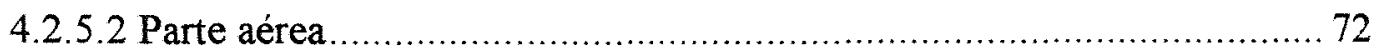

4.2.6 Relação entre produções de matéria seca de raizes e da parte aérea

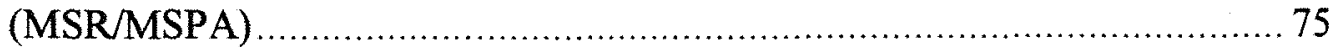

4.2.7 Concentração e acúmulo de alumínio e macronutrientes ........................... 77

4.2.7.1 Concentração e acúmulo de alumínio ........................................... 77

4.2.7.2 Concentração e acúmulo de cálcio ................................................ 86

4.2.7.3 Concentração e acúmulo de fósforo …............................................ 94

4.2.7.4 Concentração e acúmulo de magnésio ............................................... 99

4.2.7.5 Concentração e acúmulo de nitrogênio............................................ 106

4.2.7.6 Concentração e acúmulo de potássio ............................................ 112

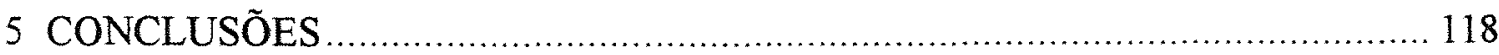

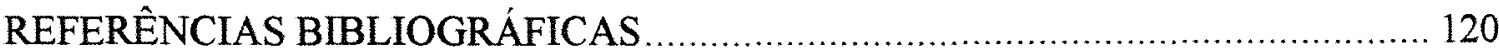




\title{
TOXICIDADE DE ALUMÍNIO EM TRINTA GENÓTIPOS DE Panicum maximum Jacq. CULTIVADOS EM SOLUÇÃO NUTRITIVA
}

\author{
Autora: ANA APARECIDA DA SILVA \\ Orientador : Prof. Dr. FRANCISCO ANTONIO MONTEIRO
}

\section{RESUMO}

O presente trabalho foi realizado na ESALQ - USP, Piracicaba - SP, no período de março de 1995 a dezembro de 1996, com o objetivo de avaliar a tolerância de trinta genótipos de Panicum maximum Jacq. ao alumínio, e identificar as relações entre a fitotoxicidade e a produção de matéria seca, perfilhamento, composição mineral e atividade das enzimas redutase do nitrato e fosfatase ácida.

Para o estudo da tolerância diferencial ao alumínio foram realizados experimentos em câmara-de-crescimento utilizando 24 acessos de Panicum maximum e os seis cultivares comerciais denominados Centauro, Centenário, Colonião, Colonião IZ-1, Tobiatã e Vencedor. As doses de alumínio foram 0;12 e $24 \mathrm{mg}$ de $\mathrm{Al} \mathrm{L}^{-1}$ de solução nutritiva. Empregou-se o delineamento experimental em blocos ao acaso, em esquema de parcelas subdivididas, com cinco repetições.

Considerando como parâmetros de avaliação o crescimento da raiz seminal, o crescimento relativo da raiz seminal, o índice de tolerância relativa ao 
alumínio e a inibição do alongamento radicular, verificou-se que os genótipos tolerantes à fitotoxicidade foram K191, T95, Centenário, T91, e T84; os de moderada tolerância foram T21, K193, T110, K217, K64, KK10, T24, T62, T97, KK8, T60, Mombaça, Vencedor e Tanzânia-1, e os sensíveis ao alumínio K68, K214, K249, KK33, T46, T72, Colonião, IZ-1, Tobiatã, T77 e Centauro.

A partir dos resultados dos experimentos realizados em câmara-decrescimento, três genótipos Panicum maximum foram escolhidos para a avaliação do efeito de doses de alumínio no crescimento, nas atividades das enzimas redutase do nitrato e fosfatase ácida e na nutrição mineral desses capins. Para tanto, foi realizado um experimento em casa-de-vegetação com os genótipos K191, T21 e Centauro utilizando solução nutritiva e cinco doses de alumínio: 0; $6 ; 12 ; 24$ e $36 \mathrm{mg}$ de $\mathrm{Al} \mathrm{L}^{-1}$.

A produção de matéria seca da parte aérea e de raizes dos genótipos K191 e T21 foi menos reduzida pela adição de alumínio na solução nutritiva, do que a do Centauro. O genótipo K191 apresentou menor redução no perfilhamento e no volume radicular comparado ao T21 e ao Centauro.

Verificou-se maior atividade da redutase de nitrato nos genótipos tolerante e intermediário, K191 e T21, respectivamente. O estresse pelo alumínio reduziu a atividades da redutase de nitrato e aumentou a atividade da fosfatase ácida nas folhas dos capins.

$\mathrm{O}$ alumínio reduziu as concentrações de fósforo, cálcio, potássio e magnésio na parte aérea e nas raízes, e elevou a concentração de nitrogênio na parte aérea das plantas. Concentrações mais elevadas de alumínio foram determinadas nas raízes do que na parte aérea dos capins. 


\title{
ALUMINUM TOXICITY IN THIRTY GENOTYPES OF Panicum maximum Jacq. GROWN IN NUTRIENT SOLUTION
}

\author{
Author: ANA APARECIDA DA SILVA \\ Adviser: Prof. Dr. FRANCISCO ANTONIO MONTEIRO
}

\section{SUMMARY}

This research was carried out at ESALQ - USP, Piracicaba - SP, in the period from March of 1995 to February of 1997, to evaluate the behavior of 30 genotypes of Panicum maximum Jacq. to rates of aluminum in nutrient solution, determining their tolerance to this element, as well as to identify the relationships among the phytotoxicity and dry matter yield, tillering, mineral composition and nitrate reductase and acid phosphatase activities.

For the study of aluminum tolerance the experiments were carried out in growth chamber using 24 genotypes of Panicum maximum and six commercial cultivars known Centauro, Centenário, Colonião, Colonião IZ-1, Tobiatã and Vencedor. The aluminum rates were $0 ; 12$ and $24 \mathrm{mg}$ of $\mathrm{Al} \mathrm{L}^{-1}$ of nutrient solution. The experiment was set in a split-plot design, with five replications.

Considering the parameters growth of seminal root, the relative seminal root length, the index of relative aluminum tolerance and Al-induced inhibition of root elongation, it was verified that genotypes K191, T95, Centenário, T91 and T84 were Al-tolerant, T21, K193, T110, K217, K64, KK10, T24, T62, T97, KK8, T60, Mombaça, Vencedor and Tanzânia-1 were moderately Al-tolerant and K68, 
K214, K249, KK33, T46, T72, Colonião, IZ-1, Tobiatã, T77 and Centauro were Al-sensitive.

Three genotypes were chosen for the evaluation of the effects aluminum rates in the growth, in the activities of the nitrate reductase and acid phosphatase enzymes and the mineral composition of those forage grasses. The experiment was carried out in a greenhouse with the genotypes K191, T21 and Centauro, using nutrient solution and five aluminum rates $(0 ; 6 ; 12 ; 24$ and $36 \mathrm{mg}$ of $\left.\mathrm{Al} \mathrm{L} \mathrm{L}^{-1}\right)$ in nutrient solution.

The dry matter yield from the tops and roots of the three genotypes were reduced by the addition of aluminum in the nutrient solution, and the grasses K191 and T21 were less affected than the Centauro. Tillering and root volume were less reduced in K191 grass than in T21 and Centauro.

K191 and T21 were significantly higher in nitrate reductase activity than in Centauro. The aluminum stress reduced the activity of the enzyme nitrate reductase and increased acid phosphatase activity in the leaves of the forage grasses.

Aluminum reduced the concentrations of phosphorus, calcium, potassium and magnesium in both the tops and roots of grasses. Nitrogen concentration increased in the tops. Higher concentrations of aluminum were found in the roots than in the tops. 


\section{INTRODUÇÃO}

A toxicidade do alumínio é um dos principais fatores limitantes à produção vegetal nos solos ácidos de toda a Terra, os quais representam $40 \%$ das terras agricultáveis no planeta. Na América Tropical, a maior parte dos solos é ácida e normalmente apresenta problemas de desequilíbrio nas quantidades dos elementos nutrientes de plantas e tem níveis elevados de alumínio na solução.

De modo geral, a baixa produtividade das principais culturas na América Latina é resultante do manejo inadequado dos Oxissolos e Ultissolos, os quais constituem cerca de $80 \%$ da área agrícola na região tropical. Esses solos comumente são ácidos, de baixa fertilidade natural e $50 \%$ deles possuem na camada subsuperficial elevada saturação por alumínio, que não raramente atinge níveis que resultam em toxicidade para as plantas.

O efeito nocivo do excesso de alumínio para as plantas é bem conhecido, mas estudos mais elucidativos sobre aspectos fisiológicos e nutricionais ainda são necessários, principalmente no tocante às forrageiras.

Estudos conduzidos em condições tropicais têm mostrado que a calagem e a adubação de áreas destinadas às pastagens promovem aumento da produção de matéria seca das plantas forrageiras, proporcionando considerável incremento tanto no ganho de peso como na produção de leite pelos animais em pastejo. Contudo, em função dos custos dos fertilizantes e corretivos (estes particularmente devido ao transporte a longas distâncias das fontes produtoras), 
têm-se procurado alternativas como a busca de espécies forrageiras adaptadas às condições adversas dos solos tropicais.

Particularmente para o Brasil, o estabelecimento de programas de melhoramento de gramíneas forrageiras assume maior importância, uma vez que $44 \%$ do rebanho bovino nacional está em áreas de cerrado, cujos solos apresentam acidez, reduzida fertilidade e alta saturação por alumínio no complexo de troca.

Desde 1984 o Centro Nacional de Pesquisa de Gado de Corte (CNPGC), da Empresa Brasileira de Pesquisa Agropecuária (EMBRAPA), em Campo Grande - MS, vem desenvolvendo criteriosos trabalhos de avaliação e seleção de genótipos de Panicum maximum Jacq. a fim de obter acessos de maior produtividade e com melhor adaptação às condições dos solos brasileiros, para posterior liberação ao pecuarista. Nesse sentido, a seleção do caráter de tolerância ao excesso de alumínio é fator importante à viabilidade e sucesso de novos cultivares que venham a ser lançados.

Assim, há necessidade de maiores informações relativas ao comportamento dessas gramíneas quanto aos fatores de estresse, entre os quais se destaca a toxicidade do alumínio. No Brasil, a espécie Panicum maximum Jacq. destaca-se pelo seu grande potencial de produção e boa qualidade como alimento animal, sendo tradicionalmente tratada como forrageira apropriada para solos férteis.

Entretanto, frente a um fator externo adverso, como o excesso de alumínio na solução do solo, é esperado que cultivares de Panicum maximum apresentem comportamento diferenciado quanto à tolerância ao fator desfavorável. A seleção de genótipos tolerantes ao alumínio tem sido efetuada de duas formas: empregando o cultivo em solo e em solução nutritiva. Como a 
toxicidade do alumínio não é o único fator de estresse em um solo ácido, muitos pesquisadores têm preferido a técnica de seleção em solução nutritiva.

É sabido que o alumínio interfere em grande número de processos biológicos, sendo a tolerância ao seu excesso decorrente de estratégias metabólicas intrínsecas a cada genótipo. Informações obtidas a partir de estudos dessa natureza poderão contribuir nos programas de seleção de novos cultivares de plantas forrageiras.

Este trabalho teve por objetivos estudar a influência do alumínio no crescimento radicular de 30 genótipos de Panicum maximum, com vistas à seleção desses de acordo com o grau de tolerância ao alumínio, bem como verificar a produção de matéria seca, o perfilhamento, a composição mineral e a atividade enzimática de plantas com genótipo tolerante, moderadamente tolerante $\mathrm{e}$ sensivel, a fim de relacionar esses aspectos fisiológicos à tolerância diferencial ao alumínio desses genótipos. 


\section{REVISÃO DE LITERATURA}

\subsection{Espécie forrageira e seus cultivares}

O gênero Panicum caracteriza-se por possuir grande variabilidade genética e morfo-fisiológica. É constituído por espécies com hábito de crescimento ereto, estolonífero e rizomatoso, por plantas tolerantes e sensíveis ao encharcamento, por ecotipos que exigem solos com fertilidade moderada e alta, tolerantes e sensiveis ao alumínio e com reprodução apomítica e sexuada (Corsi, 1995).

Panicum maximum Jacq. é a principal espécie representante do gênero no Brasil, possuindo elevada importância para a produção animal. Originária da África Tropical, essa gramínea forrageira foi trazida para as Américas acidentalmente com os navios de escravos, no final do século XVIII. Devido ao seu alto potencial produtivo, palatabilidade e boa persistência disseminou-se em vários paises como Brasil, Cuba, Estados Unidos, Peru e Porto Rico (McCosker \& Teitzel, 1975; Jank, 1994).

Entre 1967 e 1969 a espécie Panicum maximum foi amplamente coletada por pesquisadores franceses no Quênia e na Tanzânia, de forma que atualmente possuem a mais completa e representativa coleção de gramínea forrageira tropical. Esta coleção encontra-se na sua totalidade na Costa do Marfim, no Institute Français de Recherche Scientifique et Developpment en Coopération (ORSTOM) e no Brasil, no CNPGC - EMBRAPA. Parte dessa coleção também encontra-se na 
Colômbia, no Centro Internacional de Agricultura Tropical (CIAT), no México e em Cuba (Savidan et al., 1990; Jank, 1995).

De acordo com Jank (1994), vários cultivares de Panicum maximum estão disponiveis em diversos países. Assim, os cultivares Hamil, Gatton Panic e Riversdale são encontrados na Austrália, os cultivares Boringuen e Broadleaf em Porto Rico, o cultivar Likoni em Cuba, cultivar Guinea na Venezuela, o cultivar Nchisi no Quênia e os cultivares Colonião, Sempre Verde, Tobiatã, Aruana, Colonião IZ-1, Centenário, Centauro, Vencedor, Tanzânia-1 e Mombaça no Brasil.

Dentre os cultivares introduzidos no Brasil o mais difundido é o capimcolonião, o qual, segundo Aronovich (1995), ainda ocupa expressivas áreas de pastejo. Quase uma tradição como planta forrageira, este capim foi amplamente cultivado nas regiões oeste e norte do Estado de São Paulo, no sul de Goiás, na Amazônia e no sul do Espírito Santo (Simão Neto et al., 1973; Carriel et al., 1979; Guss \& Agostini, 1984; Contibrasil, 1985; Dias Filho, 1987).

Alcântara \& Bufarah (1979) referiram que essa é uma das principais gramíneas forrageiras da América Tropical, caracterizando-se pela agressividade, boa resistência ao pisoteio e ao fogo, e vegetação adequada em locais quentes com precipitação pluvial acima de $900 \mathrm{~mm}$ anuais.

O bom desempenho dessa espécie de capim associa-se a solos de textura média ou arenosa e com alta fertilidade, condições pouco freqüentes para a maioria dos solos das regiões tropicais e subtropicais. Esse fato tem estimulado as instituições de pesquisa a buscar genótipos tolerantes a condições edafoclimáticas adversas (Aronovich, 1995). De acordo com Corsi (1994), a preocupação dos pesquisadores em reavaliar os genótipos de Panicum maximum possibilitará o estabelecimento de critérios que atendam às exigências de manejo dessa forrageira. 
Um programa de seleção e melhoramento de Panicum maximum foi estabelecido no Instituto Agronômico de Campinas (IAC), através do qual ocorreram lançamentos dos cultivares Tobiatã, Centenário e Centauro (Usberti Filho, 1982; Usberti Filho et al., 1986; Usberti Filho, 1987). Em 1989 o Instituto de Zootecnia (IZ) lançou o cultivar Aruana (IZ, 1989) e, no ano seguinte os trabalhos de seleção de Panicum maximum desenvolvidos no CIAT propiciaram o lançamento do cultivar Vencedor pelo Centro de Pesquisa Agropecuária dos Cerrados (CPAC-EMBRAPA) (EMBRAPA, 1990). Como resultado da seleção direta do germoplasma de Panicum maximum o CNPGC-EMBRAPA lançou em 1990 e 1993 os cultivares Tanzânia-1 e Mombaça, respectivamente (Jank, 1995).

\subsection{O alumínio no solo}

O alumínio é importante constituinte da fração mineral do solo ocorrendo em mais de $15 \%$ da crosta terrestre como $\mathrm{Al}_{2} \mathrm{O}_{3}$ que, juntamente com o silício, compõe os minerais de argila de grade cristalina 1:1 e 2:1, além de ocorrer adsorvido à matéria orgânica e aos próprios minerais de argila (Mengel \& Kirkby, 1987).

Com o processo natural de acidificação do solo, a estabilidade química dos compostos de alumínio é reduzida ocorrendo aumento da solubilidade dos minerais, de forma que parte do alumínio total torna-se solúvel e pode ocorrer em concentração potencialmente tóxica às plantas (Tisdale et al., 1985).

Os solos ácidos abrangem $30 \%$ das terras livres de gelo (Von Uexküll \& Mutert, 1995) e 40\% das terras agricultáveis no mundo (Osmond et al., 1980), localizando-se predominantemente nas regiões tropicais e subtropicais. A América do Sul apresenta vastas áreas de solos ácidos, sendo que aproximadamente 500 milhões de hectares de Oxissolos e Ultissolos são 
subutilizados devido à extrema acidez, reduzida fertilidade e alta saturação do complexo de troca por alumínio e manganês (Fageria, 1982).

Malavolta \& Kliemann (1985) afirmaram que no Brasil, com exceção da região nordeste, cerca de dois milhões de $\mathrm{km}_{/}^{2}$ dos solos sob "cerrado" caracterizam-se pelo baixo $\mathrm{pH}$, pobreza em bases trocáveis e alta saturação por manganês e alumínio. Nos últimos 25 anos cerca de $40 \%$ da extensão original da área sob cerrado foi convertida para a agricultura (Ratter \& Ribeiro, 1996), dos quais 45 milhões de hectares são ocupados por pastagens cultivadas (Barcellos, 1996).

O conhecimento da química do alumínio em solos ácidos é de grande interesse, principalmente devido aos efeitos nocivos do íon $\mathrm{Al}^{3+}$ no crescimento vegetal. Foy et al. (1978), em revisão sobre fitotoxicidade causada por metais, relataram que o problema do alumínio se torna ainda mais sério nos horizontes subsuperticiais ácidos, nos quais é maior a concentração da espécie trivalente $\left(\mathrm{Al}^{3+}\right)$, forma preferencialmente absorvida pelas raízes das plantas. A correção do alumínio na subsuperficie, pela calagem, é muito difícil, pois o efeito dela ocorre principalmente na superficie, não atingindo o subsolo, onde o alumínio pode permanecer em níveis tóxicos.

O alumínio existente na solução do solo apresenta-se sob várias formas. Estas formas incluem o alumínio trivalente $\left(\mathrm{Al}^{+3}\right)$ e vários complexos inorgânicos (Raij, 1991) e orgânicos (Evans, 1988). Das formas inorgânicas as mais importantes são aquelas hidroxiladas, mono e polinucleares (Parker et al., 1988 e Parker et al., 1989). O alumínio trivalente caracteriza-se por polarizar fortemente a água, de maneira a coordenar seis moléculas, ou seja $\left[\mathrm{Al}\left(\mathrm{H}_{2} \mathrm{O}\right)_{6}\right]^{+3} \mathrm{em}$ configuração octaedral (Shriver et al., 1990). A hidrólise da forma trivalente é dependente de $\mathrm{pH}$ e produz íons $\mathrm{H}_{3} \mathrm{O}^{+}$na solução: 


$$
\begin{aligned}
& {\left[\mathrm{Al}\left(\mathrm{H}_{2} \mathrm{O}\right)_{6}\right]^{+3}+\mathrm{H}_{2} \mathrm{O} \leftrightarrow\left[\mathrm{Al}(\mathrm{OH})\left(\mathrm{H}_{2} \mathrm{O}\right)_{5}\right]^{+2}+\mathrm{H}_{3} \mathrm{O}^{+}} \\
& {\left[\mathrm{Al}(\mathrm{OH})\left(\mathrm{H}_{2} \mathrm{O}\right)_{5}\right]^{+2}+\mathrm{H}_{2} \mathrm{O} \leftrightarrow\left[\mathrm{Al}(\mathrm{OH})_{2}\left(\mathrm{H}_{2} \mathrm{O}\right)_{4}\right]^{+}+\mathrm{H}_{3} \mathrm{O}^{+}} \\
& {\left[\mathrm{Al}(\mathrm{OH})_{2}\left(\mathrm{H}_{2} \mathrm{O}\right)_{4}\right]^{+}+\mathrm{H}_{2} \mathrm{O} \leftrightarrow\left[\mathrm{Al}(\mathrm{OH})_{3}\left(\mathrm{H}_{2} \mathrm{O}\right)_{3}\right]^{0}+\mathrm{H}_{3} \mathrm{O}^{+}} \\
& {\left[\mathrm{Al}(\mathrm{OH})_{3}\left(\mathrm{H}_{2} \mathrm{O}\right)_{3}\right]^{0}+\mathrm{H}_{2} \mathrm{O} \leftrightarrow\left[\mathrm{Al}(\mathrm{OH})_{4}\left(\mathrm{H}_{2} \mathrm{O}\right)_{2}\right]^{-}+\mathrm{H}_{3} \mathrm{O}^{+}}
\end{aligned}
$$

Por simplificação, as formas acima são representadas sem as moléculas de água, como $\mathrm{Al}^{+3}$ ou $\mathrm{Al}(\mathrm{OH})_{\mathrm{x}}{ }^{\mathrm{y}}$. O ín $\mathrm{Al}^{+3}$ predomina em $\mathrm{pH}_{\left(\mathrm{H}_{2} \mathrm{O}\right)}$ menor que 4,7, enquanto que $\mathrm{Al}(\mathrm{OH})_{3}{ }^{0}$, forma insolúvel, é a principal espécie iônica na faixa de $\mathrm{pH}_{\left(\mathrm{H}_{2} \mathrm{O}\right)} 5,0$ a 7,0. Em pH$\left(\mathrm{H}_{2} \mathrm{O}\right) 7,5$, de acordo com Tisdale et al. (1985) o alumínio é solúvel na forma de $\mathrm{Al}(\mathrm{OH})_{4}{ }^{-}$. Quando a relação $\mathrm{Al} / \mathrm{OH}$ é alta formam-se as espécies polinucleares, das quais a forma $\mathrm{Al}_{13}$ (poli-cátion tridecamérico) é a de maior importância nos casos de toxicidade (Kinraide, 1997).

O comportamento do alumínio na fase líquida do solo é muito complexo, visto depender da ligação dele com radicais inorgânicos e orgânicos, do pH e da força iônica da solução (Camargo \& Furlani, 1989). O fluoreto é o principal ligante inorgânico do $\mathrm{Al}^{3+}$, enquanto que os ligantes orgânicos de maior afinidade são grupos carboxila $(-\mathrm{COOH})$, hidroxila $(-\mathrm{OH})$, carbonila $(-\mathrm{CO})$, sulfato $\left(\mathrm{SO}_{4}^{-2}\right)$ e fosfato $\left(\mathrm{PO}_{4}^{-3}\right)$ (Delhaize \& Ryan, 1995).

\subsection{Formas fitotóxicas do alumínio}

Magistad (1925) discutiu os efeitos tóxicos do íon $\mathrm{Al}^{3+}$, alegando sua alta insolubilidade na solução de muitos solos, o que produz $\mathrm{Al}^{3+}$ em concentração insuficiente para provocar injúrias à planta. Em um solo tipicamente ácido com $\mathrm{pH}_{\left(\mathrm{H}_{2} \mathrm{O}\right)}$ em torno 4,5 a concentração de $\mathrm{Al}^{3+}$ varia entre 10 e $40 \mu \mathrm{mol} \mathrm{L} \mathrm{L}^{-1}$ (Marschner, 1995; Vitorello, 1996). 
A solubilidade do alumínio e a severidade da fitotoxicidade dependem de vários fatores, além do $\mathrm{pH}$, como: o tipo predominante de minerais de argila, concentração dos demais cátions, ânions, sais totais e conteúdo de matéria orgânica (Camargo, 1983 e 1984). Esses fatores promovem modificações na atividade das várias espécies de íons alumínio em solução (Berton, 1989), podendo alterar a intensidade dos efeitos fitotóxicos (Parker et al., 1988).

Devido à sua solubilidade, o alumínio em solução aquosa ocorre sob diferentes espécies iônicas. Inicialmente as pesquisas que relacionam a especiação do íon com a fitotoxicidade preocupavam-se com a química do elemento na solução que banhava as raízes (Pavan \& Binghan, 1982; Alva et al., 1986). Atualmente, com o conhecimento de que o alumínio alcança rapidamente o simplasto (Lazof et al., 1994), busca-se conhecer quais são as formas de alumínio capazes de atravessar a membrana plasmática (Kochian, 1995).

A literatura é unânime em descrever que em solução ácida $\left(\mathrm{pH}_{\left(\mathrm{H}_{2} \mathrm{O}\right)}<5,0\right)$ $0 \mathrm{Al}^{3+}$ é a principal forma fitotóxica do alumínio (Foy et al., 1978; Parker et al., 1988; Kinraide, 1991; Delhaize \& Ryan, 1995).

No caso do algodão, Gossypium hirsutum, (Adams \& Lund, 1966) e do café, Coffea arabica, (Pavan \& Binghan, 1982), a inibição do crescimento radicular como resposta à presença de alumínio no substrato correlacionou-se melhor com a atividade molar do $\mathrm{Al}^{3+}$ do que com sua concentração no meio. A tolerância de gramíneas forrageiras foi determinada em solução nutritiva por Wheeler et al. (1992), os quais verificaram que a produção destas plantas reduziuse em $50 \%$ quando a atividade molar do $\mathrm{Al}^{3+}$ era maior que $4 \mu \mathrm{mol} \mathrm{L}{ }^{-1}$.

Em estudos relativos aos fatores envolvidos na tolerância de dez cultivares de trigo (Triticum aestivum), mantidos em soluções nutritivas com diversas concentrações salinas, Camargo et al. (1981) verificaram que os sintomas de toxicidade foram acentuados pelo aumento da concentração de alumínio ou 
pela diminuição da concentração de sais em solução. Tais observações somadas aos resultados apresentados por Camargo (1984) quanto à influência do pH das soluções nutritivas na fitotoxicidade do íon, demonstraram que a tolerância é relativa, visto depender não apenas da espécie e do cultivar vegetal, mas também da força iônica, $\mathrm{pH}$, atividade iônica dos íons e da formação de pares iônicos em solução.

Estudos como os de Blamey et al. (1983), Alva et al. (1986) e Kinraide \& Parker (1990) tem apontado as espécies monoméricas hidroxiladas, isto é, $\mathrm{Al}(\mathrm{OH})^{2+}$ e $\mathrm{Al}(\mathrm{OH})_{2}{ }^{+}$, como tóxicas. As espécies mononucleares parecem ser mais tóxicas às dicotiledôneas (Alva et al. , 1986; Kinraide \& Parker, 1990). Para a cultura da soja (Glycine max), Blamey et al. (1983) mostraram que a soma das atividades das espécies monoméricas de $\mathrm{Al}\left[\mathrm{Al}^{3+}+\mathrm{Al}(\mathrm{OH})^{2+}+\mathrm{Al}(\mathrm{OH})_{2}{ }^{+}+\right.$ $\left.\mathrm{Al}(\mathrm{OH})_{3}{ }^{0}+\mathrm{Al}(\mathrm{OH})_{4}\right]$ é o mais adequado para explicar os efeitos tóxicos do ín, enquanto Parker et al. (1989) concluíram que a resposta fitotóxica de espécies polinucleares de alumínio varia com a espécie ou variedade vegetal e com as condições experimentais.

Kinraide (1991), em revisão sobre formas fitotóxicas do alumínio, concluiu que o alumínio trivalente $\left(\mathrm{Al}^{3+}\right)$ e o poli-cátion tridecamérico $\left(\mathrm{Al}_{13}\right)$, assim como outros cátions com carga maior que 2 , eram prejudiciais ao crescimento radicular. Já as formas hidroxiladas (Al-OH) possuíam moderado potencial tóxico, enquanto que as demais formas de alumínio não eram tóxicas. Não obstante, Kochian (1995) alertou que a aparente toxicidade das formas mononucleares hidroxiladas deveria ser considerada com cuidado, bem como a contribuição da forma $\mathrm{Al}_{13}$ na toxicidade do alumínio em condições naturais. Reconsiderando seu trabalho de 1991, Kinraide (1997) concluiu que as formas hidroxiladas $\mathrm{Al}-\mathrm{OH}$ não são tóxicas às plantas. Baseando-se no modelo da dupla camada difusa de Guoy-Chapman-Stern, Kinraide (1997) mostrou que a 
toxicidade do alumínio tem alta correlação com a atividade do íon na superfície da membrana plasmática e, portanto, depende da sua carga, de maneira que as formas de alumínio tóxicas são: $\mathrm{Al}_{13}>\mathrm{Al}^{3+}>\mathrm{AlF}^{2}>\mathrm{AlF}_{2}^{+}$.

\subsection{Efeitos do alumínio na planta}

Há quase oitenta anos a toxicidade do alumínio vem sendo apontada como o principal fator limitante do crescimento vegetal em solos ácidos. Trabalhos como os de Hartwell \& Pember (1918), Magistad (1925) e Line (1926) foram pioneiros nesta área de estudo.

A toxicidade do alumínio é amplamente relatada na literatura e foi revisada por Foy et al. (1978), Helyar (1978), Foy (1988), Roy et al. (1988), Taylor (1988), Furlani (1989), Foy (1992), Carver \& Ownby (1995) e Kochian (1995).

A principal ação tóxica do alumínio está na inibição do crescimento radicular, que ocorre rapidamente após o contato da raiz com a solução que contém o íon $\mathrm{Al}^{3+}$ (Lazof et al., 1994). Monitorando o crescimento de raízes de plantas de milho (Zea mays) com tolerância diferencial ao alumínio, Llungany et al. (1994) observaram que nas plantas sensíveis a inibição do alongamento radicular ocorreu em 30 a 90 minutos após a exposição à solução contendo o íon.

Os sintomas da fitotoxicidade do alumínio são inespecíficos, caracterizando-se também como sintomatologia de deficiência induzida de fósforo, cálcio ou magnésio (Roy et al., 1988; Foy, 1992; Marschner, 1995).

As plantas respondem diferentemente ao alumínio (Foy et al. ,1978; Taylor, 1988). Floss (1992) estudando o comportamento de genótipos de aveia branca (Avena sativa) e aveia preta (Avena strigosa) a doses de alumínio observou diferenças significativas no grau de tolerância das plantas quando expostas a 7,5 e $15 \mathrm{mg}$ de $\mathrm{Al} \mathrm{L}{ }^{-1}$ de solução nutritiva. Realizando a seleção de 37 
cultivares de milho em solução nutritiva, Horst et al. (1997) encontraram expressivas diferenças na resistência ao alumínio entre as plantas analisadas.

Foy (1983) descreveu que para algumas plantas, baixas doses de alumínio podem ser benéficas ao crescimento. Silva (1992) verificou que o crescimento de plantas de arroz (Oryza sativa) de sequeiro foi estimulado pela adição de até $5 \mathrm{mg}$ de $\mathrm{Al} \mathrm{L}^{-1}$ de solução nutritiva. A natureza dos efeitos benéficos do alumínio ainda é desconhecida, mas Kinraide (1993) e Huang \& Bachelard (1993) postularam que esse estímulo ao crescimento ocorre sob condições de estresse ao $\mathrm{H}^{+}$, concluindo que o $\mathrm{Al}^{3+}$ minimiza a toxicidade do $\mathrm{H}^{\top}$.

\subsubsection{Efeitos do alumínio nas raízes}

As raízes constituem o principal órgão do vegetal a ser afetado pelo excesso de alumínio. Elas apresentam-se curtas, grossas e frágeis, possuindo ápices espessos e coloração marrom. O sistema radicular assume aspecto coralóide, pois ocorre formação de numerosas raízes laterais, cujo crescimento também é reduzido (Foy, 1974), o que torna o sistema radicular ineficiente na absorção de água e nutrientes (Lance \& Pearson, 1969). Tal efeito é mais marcante na fase de plântula, o que tem sido demonstrado através de experimentos de curta duração (Vose, 1990).

Bartlet \& Riego (1972) verificaram que as raizes de plantas cultivadas na presença de alumínio se tornaram quebradiças e o crescimento dos seus ápices foi inibido. Ryan et al. (1993), trabalhando com raizes de milho, observaram que o ápice radicular foi o sítio de ação tóxica do alumínio, uma vez que o alongamento da raiz decapitada não foi inibido quando da exposição ao alumínio em solução. A inibição do alongamento celular do ápice radicular é rápida, podendo ser detectada em uma ou duas horas após a exposição ao alumínio (Lazof et al., 1994; Vitorello, 1996). 
Os efeitos citológicos da toxicidade manifestam-se pelo aparecimento de anomalias durante o processo mitótico das células do ápice radicular (Clarkson, 1965; Sampson et al., 1965; Hecht-Buchholz \& Schuster, 1987). Mais recentemente, Kochian (1995) relatou que a rápida inibição do crescimento radicular resulta primeiramente da ação do elemento no processo de alongamento das células, enquanto os efeitos inibitórios da divisão celular são posteriores.

Zhang \& Taylor (1990), utilizando raizes cortadas de plantas de trigo (Triticum aestivum) tolerante e sensível ao alumínio, concluíram que a cinética de absorção de alumínio é bifásica, ou seja, a absorção inicialmente é rápida e não linear, seguida por uma fase lenta e linear. A primeira fase foi interpretada como sendo de acumulação de alumínio trocável na parede celular, visto que o alumínio sofre dessorção quando da adição de citrato. A segunda fase incluiria o cátion presente na parede celular, que não sofreu dessorção, bem como aquele transportado para o simplasto, que, portanto, é dependente do metabolismo do íon acumulado na parede celular.

Roy et al. (1988) e Delhaize et al. (1993) citaram que grande quantidade do alumínio se prende à parede celular e ao plasmalema das células da epiderme radicular, que funcionam como barreiras ao movimento do alumínio em direção ao estelo. Pode ainda ocorrer acúmulo, em menor grau, na hipoderme, no córtex e na endoderme. Em plantas acumuladoras de alumínio, como o chá (Thea sinensis) (Foy et al., 1978) e espécies nativas do "cerrado" brasileiro (Haridasan, 1982), a endoderme age como barreira, determinando menor transporte desse cátion para as folhas. Vários trabalhos detectaram a presença do elemento adsorvido ou precipitado como fosfato de alumínio na superfície radicular, nas paredes celulares, no protoplasma e no espaço livre aparente das células da raiz de diferentes plantas (Wright, 1943; Randal \& Vose, 1963; Clarkson, 1966; McCormick \& Borden, 1974). 
De acordo com Kochian (1995) a passagem do $\mathrm{Al}^{3+}$ através da membrana plasmática das células da raiz ainda é motivo de discussão, acreditando-se que possa ser feita via carregadores protéicos de íons (fitosideróforos), via fase fluída ou endocitose. Devido à similaridade em raio iônico, o fitosideróforo para $\mathrm{Fe}^{3+}$ quelatiza o $\mathrm{Al}^{3+}$, facilitando sua absorção. Gassmann \& Schroeder (1994) referiram que o $\mathrm{Al}^{3+}$ bloqueia os canais de passagem de outros íons. Matsumoto et al. (1976) observaram que em células da raiz de plantas de ervilha (Pisum sativum), o alumínio liga-se aos grupos fosfatos das moléculas de DNA, o que indica ser esse elemento absorvido via apoplasto e simplasto.

Huck (1972) verificou que o alumínio inibe a deposicão de material de parede celular, fato que associado à inibição da divisão celular (Clarkson, 1965) culmina com o aparecimento de células polinucleadas na região meristemática do ápice radicular. Além de afetar a atividade do meristema e o alongamento das células do ápice radicular (Ryan et al., 1993), a toxicidade do alumínio altera o crescimento das células da coifa (Bennet \& Breen, 1991) e dos pêlos absorventes (Jones \& Kochian, 1995).

Em uma série de trabalhos está relatado que o excesso de alumínio aumenta a rigidez da parede celular. Em plantas de trigo tratadas com alumínio, Sasaki et al. (1996) observaram que na região de alongamento da raiz as células apresentaram maior deposição de lignina na parede celular. Esse aumento na rigidez da parede pode ser decorrente da ligação cruzada do alumínio com resíduos carboxílicos das pectinas da lamela média (Foy, 1974 e 1983; Blamey et al., 1993). De modo similar, o alumínio pode se ligar às proteínas, fosfolipídeos e heterosídeos da membrana plasmática, promovendo alterações na sua estrutura e permeabilidade (Siegel \& Haug, 1983; Pfeffer et al., 1987; Zhao et al., 1987). Huang et al. (1992), analisando o efeito do alumínio no potencial elétrico transmembrânico das células das raizes de trigo, concluíram que embora $o$ 
alumínio promova alterações no crescimento e morfologia das raízes, não há sérios danos na membrana plasmática.

Vários processos metabólicos são alterados pelo alumínio decorrente da inibição da atividade de muitas enzimas, como é o caso da desidrogenase do isocitrato, enzima málica (Anderson \& Evans, 1956), hexoquinase (Clarkson, 1966; Slaski, 1994), ATPase estimulada pela calmodulina (Siegel \& Haug, 1983, Haug \& Vitorello, 1996a), fosfatases de membrana (Zaini \& Mercado, 1985; Pfeffer et al., 1987), desidrogenases da via das pentose-fosfato (Slaski, 1994) e redutase do nitrato (Cambraia et al., 1989).

O alumínio promove a sintese de calose (Schaeffer \& Walton, 1990). Horst et al. (1997) verificaram que em milho a inibição radicular induzida pelo alumínio se relacionou positivamente à formação de calose nos ápices radiculares, e sugeriram que este seria um excelente indicador de toxicidade do alumínio.

O alumínio promove inibição da função secretória do complexo de Golgi, reduzindo a incorporação de sacarose nas paredes celulares (Huck, 1972). De acordo com Kochian (1995), o encurtamento e engrossamento das raízes e pêlos radiculares indicam que o ín $\mathrm{Al}^{3+}$ induz alterações no arranjo dos microfilamentos e microtúbulos (citoesqueleto), os quais direcionam o transporte das vesículas secretoras do complexo de Golgi para a superfície celular.

\subsubsection{Efeitos do alumínio na parte aérea}

Plantas como o chá, o arroz, o trigo e a alfafa (Medicago sativa), acumulam apreciáveis quantidades de alumínio em sua parte aérea (Roy et al., 1988). Segundo Foy (1974), algumas espécies vegetais são utilizadas como indicadoras de depósitos de bauxita, como é o caso de Gleichenia linearis, pois são acumuladoras obrigatórias de alumínio. 
No caso de fitotoxicidade de alumínio os sintomas manifestados pela parte aérea da planta são variados e nem sempre de fácil identificação (Foy, 1983; Roy et al., 1988). Em algumas espécies assemelham-se aos sintomas da deficiência de fósforo, com redução do tamanho das folhas que se tornam avermelhadas. Em outras, a toxicidade do alumínio associa-se ao enrolamento das folhas novas e morte da gema apical, típico na deficiência de cálcio. Muitas vezes há clorose internerval de folhas novas, como na deficiência de ferro (Furlani, 1989).

De acordo com Fageria (1982) e Pavan \& Binghan (1982), o crescimento caulinar também é reduzido pela presença de alumínio. Foy et al. (1978) relataram que a sintomatologia geral da toxicidade assemelha-se àquela da deficiência de fósforo, devido ao aparecimento de folhas atrofiadas, as quais apresentam maturidade tardia, coloração verde-azulada seguida de clorose e bronzeamento, que evoluem para necrose. Em outros casos pode ocorrer enrolamento da lâmina foliar, colapso dos pontos de crescimento e pecíolos, equivalente ao que ocorre na deficiência de cálcio (Furlani, 1989).

Em arroz, Sarkunan et al. (1984) verificaram correlação positiva entre a adição de alumínio e a redução na síntese de amido e proteínas, no total de carboidratos solúveis e aminoácidos livres, na quantidade de pigmentos fotossintéticos total e na translocação de açúcares. Taleb et al. (1995) concluíram que plantas de milho cultivadas em solução com alumínio, mostraram redução na fotossíntese por rompimento das lamelas e tilacóides do cloroplasto. Resultados semelhantes foram apresentados por Hoddinott \& Richter (1987) para feijoeiro (Phaseolus vulgaris) e por Moustakas et al. (1995) para trigo.

Foy et al. (1978) relataram que a fitotoxicidade do alumínio correlaciona-se negativamente com a redução da taxa respiratória e com a síntese de nucleotídeos. Evidências da interferência do elemento no "turnover" de 
compostos de alta energia, como o ATP, foram mencionadas por Clarkson (1965), Foy et al. (1978) e Sarkunan et al. (1984).

\subsection{Respostas das gramíneas forrageiras ao alumínio}

Segundo Spain \& Andrew (1976), há uma tolerância diferencial à fitotoxicidade ao alumínio entre as gramíneas forrageiras. A literatura tem descrito que, em geral, as gramíneas forrageiras de clima temperado são mais sensiveis ao excesso de alumínio que aquelas de clima tropical, uma vez que as últimas se mostram menos responsivas à calagem (Spain \& Andrew, 1976; Siqueira, 1986).

Siqueira (1986) relatou que em um experimento com latossolo vermelhoamarelo, realizado em casa-de-vegetação, foram verificados aumentos significativos na produção de matéria seca de Brachiaria decumbens, Brachiaria humidicola e Melinis minutiflora quando da aplicação de $800 \mathrm{~kg}$ de $\mathrm{CaCO}_{3} \mathrm{ha}^{-1}$, concluindo que essas forrageiras eram tolerantes à acidez e ao alumínio do solo, visto que a saturação do elemento, naquela condição, era de $42 \%$.

Arruda et al. (1983) relataram que a Brachiaria decumbens apresentou crescimento satisfatório quando cultivada em solo com $72 \%$ de saturação por ahumínio, desde que adequadamente suprida com nitrogênio, fósforo e potássio. Segundo Roche et al. (1990), a Brachiaria humidicola apresenta grande adaptabilidade a solos com alta saturação por alumínio.

Pesquisando o efeito de doses de alumínio em Brachiaria decumbens e Cenchrus ciliaris, espécies tolerante e sensível ao alumínio, respectivamente, Fernandes et al. (1984) observaram que a adição de $6 \mathrm{mg}$ de $\mathrm{Al} \mathrm{L}^{-1}$ em solução nutritiva determinou a redução da produção de matéria seca total da Brachiaria decumbens em $30,4 \%$ e de Cenchrus ciliaris em 51,7\%. 
No Brasil, o capim-colonião é o mais conhecido representante de Panicum maximum, apresentando, porém, baixas persistência e produção de matéria seca em solos ácidos. Hutton \& Sousa (1987), trabalhando com híbridos de Panicum maximum em um oxissolo ácido e com elevada saturação por alumínio, típico do Brasil Central, verificaram maiores produções de matéria seca para o híbrido CPAC 3148 do que para os cultivares Makueni e Colonião, sugerindo o primeiro como possível genótipo adaptado a latossolos com baixa fertilidade e baixo $\mathrm{pH}$, bem como alumínio em níveis tóxicos.

Usberti Filho et al. (1987), avaliando híbridos e cultivares de Panicum maximum quanto à tolerância ao alumínio em solução nutritiva, relataram que os cultivares Guiné e Coloninho se mostraram sensíveis, o cultivar Tobiatã moderadamente tolerante e o cultivar Centenário tolerante.

Wheeler \& Dodd (1995) apontaram a toxicidade ao alumínio como o principal fator limitante da produção de plantas forrageiras em pastagens da Nova Zelândia, nos solos com camada subsuperficial ácida, com alta saturação por alumínio.

Objetivando avaliar os efeitos do alumínio no crescimento de 28 cultivares de gramíneas forrageiras de clima temperado, Edmeades et al. (1991) realizaram 24 experimentos em solução nutritiva e encontraram grande amplitude no grau de tolerância ao alumínio, reportando o Lolium perene c.v. Nui como a espécie mais sensível e o Agrostis tenuis a mais tolerante. Observaram ainda que, para a maior parte dos cultivares testados, a produção de matéria seca foi reduzida em $50 \%$ quando a atividade do íon $\mathrm{Al}^{3+}$ era maior que $4 \mu \mathrm{M}$, sendo que o alumínio reduziu mais acentuadamente a produção de raízes que de parte aérea.

\subsection{O alumínio e a nutrição da planta}

Inúmeras pesquisas enfocam aspectos do estresse de alumínio influindo na absorção, no transporte e na utilização de nutrientes, principalmente cálcio, 
fósforo, nitrogênio e magnésio pelos vegetais (Randal \& Vose, 1963; Lance \& Pearson, 1969; Andrew et al., 1973; Clark \& Brown, 1974; Brauner \& Sarruge, 1980; Alam, 1981; Fageria \& Carvalho, 1982; Fahl et al., 1982; Primavesi et al., 1987). De modo geral, o alumínio reduz as concentrações da maioria dos nutrientes nos tecidos vegetais (Foy et al., 1978; Foy ,1988).

Apesar dos indicativos de interações dos nutrientes com o alumínio, os efeitos na nutrição mineral são dependentes da espécie e do cultivar vegetal, bem como das condições experimentais e do grau de estresse (Furlani, 1989).

\subsubsection{Cálcio}

A similaridade entre a sintomatologia da toxicidade do alumínio e a deficiência de cálcio indica que a interação alumínio-cálcio é um componente importante nessa fitotoxicidade.

A inibição da absorção de cálcio pelo alumínio é citada em várias revisões (Foy et al., 1978; Roy et al., 1988; Taylor, 1988). A limitada absorção de cálcio na presença de $\mathrm{Al}^{3+}$ foi interpretada por Sivaguru \& Paliwal (1993) como uma das causas da toxicidade do alumínio em plantas de arroz. Wilkinson \& Duncan (1993) relataram que a absorção de ${ }^{45} \mathrm{Ca}^{2+}$, pelas raízes de plantas de sorgo (Sorghum bicolor), diminuiu com o aumento das doses de alumínio na solução nutritiva.

Os estudos conduzidos por Johnson \& Jackson (1964), Arminger et al. (1968), Foy et al. (1969), Lance \& Pearson (1969) e Furlani \& Clark (1981) indicam que plantas expostas ao alumínio acumulam menos cálcio. As plantas sensíveis ao alumínio acumularam menos cálcio nas folhas, indicando que a toxicidade reduz não só a absorção como também o transporte de cálcio das raizes para a parte aérea do vegetal (Sivaguru \& Paliwal, 1993). Huang et al. (1993) 
apresentaram resultados significativos de inibição na absorção e na translocação de cálcio quando as plantas de trigo forrageiro foram expostas ao alumínio.

Atualmente, o papel do cálcio na toxicidade do alumínio tem sido estudado, enfocando os seguintes aspectos: $(i)$ inibição da absorção de cálcio pelo alumínio; (ii) deslocamento do cálcio pelo alumínio no apoplasto e (iii) desbalanço do cálcio no citoplasma (Delhaize \& Ryan, 1995).

A absorção de cálcio pelas células é mediada por canais na membrana plasmática (Tester, 1990), e a sua restrição pelo alumínio é, de acordo com Lindberg (1990), um fenômeno de inibição competitiva. Em plantas de trigo, Huang et al. (1992) mostraram que a inibição da absorção de cálcio pelo alumínio é rápida, reversivel e maior nas plantas sensiveis do que nas tolerantes, sugerindo que o alumínio age na face externa da membrana plasmática bloqueando os canais de influxo de cálcio. Ryan \& Kochian (1993) demonstraram que tanto o íon $\mathrm{La}^{3+}$ quanto $\circ \mathrm{Al}^{3+}$ inibem o influxo de cálcio em células de raizes de plantas de trigo, e que o bloqueio dos canais de cálcio por ambos os íons se dá pela similaridade dos raios iônicos $\left(\mathrm{La}^{3+}=0,475 \mathrm{~nm} \mathrm{e} \mathrm{Al}^{3+}=0,452 \mathrm{~nm}\right)$. Contudo, Ryan et al. (1994) verificaram que baixas concentrações de alumínio inibem o crescimento radicular sem interferir na absorção de cálcio, e a adição de sódio ou magnésio à solução que contém alumínio estimula o crescimento da raiz ao mesmo tempo em que inibe a absorção de cálcio.

Utilizando plantas de trigo, Kinraide \& Parker (1987) observaram que o alumínio estabelece competição com o cálcio pelos sítios ativos externos de ligação na parede celular. A localização do alumínio na parede celular sugere que as reações de cátion no apoplasto são importantes na resposta fitotóxica. Blamey et al., 1993) sugeriram que a toxicidade está associada à ligação do alumínio aos pectatos de cálcio da parede celular. O alumínio pode bloquear ou neutralizar as cargas negativas do espaço livre aparente das células radiculares, impedindo a 
adsorção de cálcio (Gassmann \& Schroeder, 1994). Esse fato serve para reforçar o conceito de que a tolerância ao alumínio pode estar associada à capacidade da planta em resistir à deficiência de cálcio (Foy et al., 1978). Rengel (1992) sugeriu que o alumínio compete com o cálcio pelos ligantes do apoplasto, deslocando esse último dos sítios de ligação na parede celular.

A menor absorção de cálcio decorrente da presença de alumínio afeta a homeostase de cálcio no citoplasma (Ryan \& Kochian, 1993; Lindberg \& Strid, 1997). O cálcio livre no citoplasma atua como "segundo mensageiro" (Kauss, 1987), regulando muitos processos metabólicos importantes. Estudando os mecanismos moleculares e celulares de ação do alumínio, Haug et al. (1994) discutiram a hipótese de que as interações entre alumínio e cálcio citoplasmático na transdução de sinais externos associada aos fosfoinositídeos, são os eventos primários na toxicidade do alumínio. A via sinalizadora associada aos fosfoinositídeos é o sítio provável de interação das ações inibitórias do alumínio. A presença de alumínio na célula coincide com menor acúmulo de fosfatos de inositol, especialmente 1,4,5-trifosfato-inositol (IP3), concomitante com a alteração na homeostase do cálcio citoplasmático. Dessa maneira, vários processos metabólicos regulados via fosfoinositídeos seriam inibidos.

Outra via regulatória de reações bioquímicas que envolve o cálcio está associada à calmodulina. A calmodulina é uma proteína ácida globular, com cerca de 1700 daltons, 148 resíduos de aminoácidos e com quatro sítios de ligação para o cálcio, crucial para a regulação do metabolismo de células eucarióticas (Cambraia, 1989; Haug \& Vitorello, 1996a e 1996b). Siegel \& Haug (1983) relataram que a afinidade do cátion $\mathrm{Al}^{3+}$ a essa proteína supera a do cálcio em dez vezes, sugerindo que o alumínio trivalente se liga estequiometricamente aos sítios de cálcio da calmodulina promovendo mudanças conformacionais na mesma, e em decorrência inibe sua atividade biológica. Entretanto, Haug \& Vitorello 
(1996a) referiram que, apesar da elevada afinidade do $\mathrm{Al}^{3+}$ à calmodulina, os sítios de ligação são diferentes daqueles do $\mathrm{Ca}^{2+}$. A literatura reporta resultados controversos sobre o fato de que a interação alumínio-calmodulina seria o alvo primário na toxicidade do alumínio (Kochian, 1995). Estudos de cinética e termodinâmica têm mostrado que o $\mathrm{Al}^{3+}$ não desloca $\circ \mathrm{Ca}^{2+}$ dos sítios de ação da calmodulina, o que, segundo Haug \& Vitorello (1996a), não descarta a importância dos efeitos do alumínio na calmodulina, apesar dos resultados de suas pesquisas indicarem que o alumínio primeiramente age nos fosfoinositídeos da membrana plasmática, que são dependentes do cálcio livre no citoplasma.

\subsubsection{Fósforo}

Freqüentemente os sintomas da fitotoxicidade do alumínio assemelhamse àqueles da deficiência de fósforo (Clark \& Brown, 1974; Foy et al., 1978; Foy, 1988; Foy,1992). Em algumas espécies vegetais a tolerância ao excesso de alumínio tem sido relacionada à habilidade em absorver e utilizar o fósforo. Para algumas plantas, a resistência ao alumínio relaciona-se ao suprimento de fósforo, de forma que adição de fosfato resulta em desaparecimento dos efeitos negativos do cátion (Hairiah et al., 1993). Entretanto, Furlani \& Furlani (1991), determinando índices de eficiência na utilização de fósforo e tolerância ao alumínio, encontraram baixos coeficientes de correlação, concluindo que essas características são independentes.

Analisando as concentrações de fósforo na parte aérea e no sistema radicular de plantas de trigo tratadas com alumínio, Foy et al. (1965) verificaram que o cultivar sensível acumulou menos fósforo na parte aérea do que o cultivar tolerante. Provavelmente essa resposta seja decorrente da formação de complexos de fósforo e alumínio que precipitam no interior das raízes (Clarkson, 1965; Sivaguru \& Paliwal, 1993). De modo geral, o alumínio aumenta a concentração de 
fósforo nas raizes e diminui na parte aérea (Jarvis \& Hatch, 1987). Wheeler \& Dodd (1995), estudando o efeito do alumínio em 143 genótipos de leguminosas forrageiras de clima temperado, observaram que a presença do alumínio promoveu aumento da concentração de fósforo nas raizes e decréscimo na parte aérea. Segundo Clarkson (1966) e Clarkson (1967) o alumínio e o fósforo formam precipitados nas superficies radiculares e paredes das células das raízes, determinando seu acúmulo nesse órgão vegetal.

Clarkson (1966) observou em seções histológicas de raízes de plantas de cevada (Hordeum vulgare) reações contínuas de precipitação de fosfato de alumínio. McCormick \& Borden (1974) mencionaram que o fosfato de alumínio formado se precipita na mucilagem que reveste o ápice radicular. Exames detalhados das células radiculares de plantas tratadas com alumínio mostraram a existência de ligação cruzada do alumínio com o DNA através de seus grupamentos fosfato (Matsumoto et al., 1976). A toxicidade de alumínio pode manifestar-se por redução nos níveis de nucleosídeos trifosfatos (como o trifosfato de adenosina) e inibição da atividade da ATPase e outras fosfatases de membrana (Furlani, 1989).

\subsubsection{Nitrogênio}

Como a nitrificação é inibida em $\mathrm{pH}$ baixo, em solos ácidos a forma predominante de nitrogênio é o amônio $\left(\mathrm{NH}_{4}^{+}\right)$. Conforme Foy (1988), plantas adaptadas a esses solos absorvem preferencialmente amônio $\left(\mathrm{NH}_{4}^{+}\right)$ao nitrato $\left(\mathrm{NO}_{3}^{-}\right)$. Plantas tolerantes ao alumínio são capazes de utilizar eficientemente o $\mathrm{NO}_{3}^{-}$na presença de $\mathrm{NH}_{4}^{+}$. Foy et al. (1965) foram os primeiros a formularem a hipótese de que a tolerância diferencial ao alumínio em cultivares de trigo era decorrente de distintas relações $\mathrm{NH}_{4}^{+} / \mathrm{NO}_{3}^{-}$. 
Foy \& Fleming (1978) e Fleming (1983) concluíram que a tolerância ao excesso de alumínio em certos cultivares de trigo é proporcionada pela capacidade de absorção e utilização eficiente do $\mathrm{NO}_{3}{ }^{-}$na presença de $\mathrm{NH}_{4}{ }^{+}$, o que eleva o $\mathrm{pH}$ do meio de crescimento ou da rizosfera. Recentemente, Hairiah et al. (1994), estudando o comportamento de plantas de Mucuna pruriens, não verificaram qualquer relação entre a forma de nitrogênio fornecida no substrato e a tolerância ao alumínio pelo vegetal.

A relação entre a fitotoxicidade do alumínio e a forma de nitrogênio no meio de crescimento reside em uma alteração do balanço de cátions-ânions (McCain \& Davies, 1983), que, consequentemente, modifica o $\mathrm{pH}$ da rizosfera e a concentração de espécies monoméricas de alumínio e cálcio em solução (Blamey et al., 1983). Jacob-Neto et al. (1997) estudando as conseqüências no balanço cátions-ânions da interação alumínio e fontes de nitrogênio, concluíram que, independente da fonte, o feijoeiro estressado por alumínio sempre acumulou menos cátions.

De acordo com Klotz \& Horst (1988) a forma de se suprir nitrogênio influencia os efeitos fitotóxicos do alumínio devido a possível competição entre $\mathrm{NH}_{4}^{+}$e $\mathrm{Al}^{+3}$ pelos sítios de ligação na parede celular. Cambraia et al. (1987) referiram que na presença de alumínio em solução ocorreu redução na concentração de nitrato tanto no sistema radicular como na parte aérea de cultivares de sorgo tolerante e sensível ao alumínio.

\subsubsection{Magnésio, potássio, enxofre e micronutrientes}

Grimme (1983) referiu que o alumínio promove inibição da absorção de magnésio pelas raizes de aveia, o que foi ratificado por Truman et al. (1986) e Floss (1992). Foy (1988) relatou para arroz que a presença de alumínio limitou a absorção dos macronutrientes e dos micronutrientes. A presença de alumínio na 
solução nutritiva resultou em redução nas concentrações de potássio, magnésio e enxofre nas raízes e na parte aérea de cultivares de sorgo tolerante e sensível ao alumínio (Cambraia et al., 1987). Lee (1971) já havia associado a tolerância ao alumínio à absorção de maior quantidade de magnésio e de potássio, e HechtBuchholz \& Schuster (1987) afirmaram que plantas eficientes na absorção e/ou utilização do magnésio resistem ao estresse de alumínio.

Dentre os nutrientes, o magnésio e o ferro são os que possuem raio iônico mais próximo ao do alumínio (Martin, 1988). O magnésio está intimamente associado ao metabolismo de compostos fosfatados (Leningher et al., 1995). De acordo com Vitorello (1996) na hidrólise dos nucleotídeos a constante de ligação do alumínio aos nucleosídeos trifosfatos é $10^{7}$ vezes maior que a do magnésio.

Wheeler \& Dodd (1995) estudando o efeito do alumínio em 143 genótipos de leguminosas forrageiras de clima temperado, observaram que a presença do alumínio promoveu aumentos nas concentrações de manganês, cobre, ferro, boro e zinco, acompanhados por decréscimos nas concentrações de enxofre, potássio e magnésio nas raízes e parte aérea das plantas. Gonçalves et al. (1996) relataram que a presença de alumínio na solução fez decrescer linearmente a concentração de zinco nas plantas de sorgo. Em plantas de centeio forrageiro (Secale cereale), Rengel \& Robinson (1989) encontraram resultados similares, concluindo que o alumínio reduz o influxo de zinco nas raízes.

Pesquisando o efeito de doses de alumínio em Brachiaria decumbens e Cenchrus ciliaris, espécies tolerante e sensível ao alumínio, respectivamente, Fernandes et al. (1984) observaram aumento na concentração de potássio em Brachiaria enquanto que em Cenchrus houve redução, em resposta à adição de $\mathrm{Al}$ na solução nutritiva. Em trigo forrageiro, Huang \& Grunes (1992) observaram que na presença de alumínio plantas tolerantes e sensíveis apresentaram concentrações 
mais baixas de potássio, magnésio, cálcio, cobre e zinco, enquanto que as concentrações de ferro e manganês foram reduzidas apenas nas plantas sensíveis.

Otsuka (1970) constatou sintomas visuais de deficiência de ferro em plantas de trigo e cevada cultivadas em solução com alumínio. Alam \& Adams (1980) encontraram que o alumínio também induz a deficiência de ferro em plantas de aveia, postulando que o alumínio interfere na redução de $\mathrm{Fe}^{3+}$ a $\mathrm{Fe}^{2+}$ na célula.

Petterson \& Strid (1989) demonstraram que a absorção de potássio é inibida em plantas de trigo sensíveis ao alumínio. Lindberg \& Strid (1997) concluíram que, independente do grau de tolerância da planta, o alumínio promove redução na concentração de potássio no citoplasma de células da raiz, provavelmente por provocar aumento no efluxo de potássio (Sasaki et al., 1994) ou por inibir a absorção do mesmo.

Plantas tolerantes ao alumínio produzem ácidos orgânicos que parecem agir como quelantes do alumínio, dentro e fora da célula (Jones, 1961). Pitta et al. (1997), estudando a interação entre alumínio e potássio na exsudação de ácidos orgânicos por plantas de sorgo, verificaram que a adição de potássio na solução com alumínio promoveu maior exsudação dos ácidos trans-aconítico, tartárico e málico.

\subsection{Influência do alumínio na atividade da redutase do nitrato}

A redutase do nitrato é a primeira enzima envolvida na assimilação de nitrato pelas plantas. De acordo com Rao et al. (1977) e Gallaher et al. (1980), genótipos de trigo tolerantes ao alumínio apresentaram maior atividade da redutase do nitrato do que os genótipos sensiveis. Na maioria das plantas a atividade da redutase do nitrato é mais elevada nas folhas do que nas raizes (Beevers \& Hageman, 1969). A atividade dessa enzima é estimulada pela 
absorção de nitrato (Ben Zioni et al., 1971) e apresenta dois picos de máximo nos estágios iniciais de desenvolvimento da planta (Hoarao et al., 1991).

A influência do alumínio na atividade da redutase do nitrato foi estudada na cultura do trigo por Foy \& Fleming (1982), os quais constataram atividade mais elevada da enzima em genótipos tolerantes que nos sensiveis, independente da presença de alumínio. Plantas que exibem elevada atividade da redutase do nitrato são mais eficientes na absorção $e$ utilização do nitrato e, consequentemente, a troca de $\mathrm{OH}^{-}$por $\mathrm{NO}_{3}^{-}$mantém alto o $\mathrm{pH}$ na rizosfera, o que garante resistência à toxicidade do alumínio.

Cambraia et al. (1989) estimaram as constantes cinéticas da redutase do nitrato presente na parte aérea e raízes de plantas de sorgo cultivadas na presença de alumínio. $\mathrm{O}$ cátion $\mathrm{Al}^{3+}$ promoveu decréscimos de $98 \%$ e $71 \%$ na velocidade máxima (Vmáx) e aumentos na constante de Michaelis-Menten (Km) de $267 \%$ e $42 \%$ nos cultivares sensível e tolerante, respectivamente. Dinev \& Stancheva (1993) observaram que a atividade da redutase do nitrato nas folhas de trigo e triticale (Triticale hexaploide) se elevou com a adição de alumínio na solução nutritiva.

\subsection{Influência do alumínio na atividade da fosfatase ácida}

A fosfatase ácida é uma enzima cuja atividade é aumentada na deficiência de fósforo em diversas espécies vegetais. $O$ aumento na atividade parece decorrer da síntese "de novo" da enzima, que é inibida pelo íon fosfato em um mecanismo de retroinibição (Reid \& Bielesk, 1970). A atividade da fosfatase ácida foi estudada em raízes (McLachlan, 1976; McLachlan \& De Marco, 1982; Zaini \& Mercado, 1985a e 1985b; Juma \& Tabatabai, 1988), bem como em folhas (McLachlan \& De Marco, 1982) de várias espécies vegetais. 
Em algumas espécies vegetais a tolerância ao excesso de alumínio tem sido relacionada à habilidade das plantas em absorver e utilizar o fósforo. Neste sentido, Zaini \& Mercado (1985a) postularam que a tolerância ao alumínio do cultivar de arroz IAC-3 era conseqüência da elevada atividade da fosfatase no sistema radicular, a qual hidrolisando compostos orgânicos ricos em fósforo, libera fosfato inorgânico para a célula e impede o surgimento de deficiência de fósforo induzida pelo alumínio.

\subsection{Mecanismos de tolerância ao alumínio}

Muitas pesquisas têm procurado elucidar os mecanismos de tolerância à fitotoxicidade do alumínio, os quais ainda não foram esclarecidos em virtude das causas bioquímicas não serem conhecidas (Bennet \& Breen, 1991; Delhaize \& Ryan, 1995; Kochian, 1995), bem como das limitações metodológicas advindas da complexa química do alumínio (Rengel, 1992; Delhaize \& Ryan, 1995). Devido aos efeitos múltiplos do alumínio na célula, ainda não há consenso entre os autores se o sítio celular de toxicidade do alumínio é simplástico ou apoplástico (Kochian, 1995).

As espécies vegetais, assim como os cultivares de uma mesma espécie, apresentam grande variabilidade quanto ao grau de susceptibilidade ao excesso de alumínio (Foy, 1974; Hecht-Buchholz \& Schuster, 1987). Essa variação é muito útil ao melhoramento genético para o desenvolvimento de genótipos resistentes. Usberti Filho et al. (1987), avaliando a tolerância ao estresse de alumínio em alguns genótipos de Panicum maximum, constataram que os genótipos de ciclo tardio, como o cultivar Tobiatã, possuem moderada tolerância, enquanto que aqueles de ciclo precoce, como o cultivar Coloninho, foram sensíveis ao alumínio. Wheeler (1995), estudando a tolerância relativa ao alumínio em espécies de gramíneas forrageiras recomendadas para a Nova Zelândia, encontrou 
a seguinte ordem decrescente de tolerância: Zea mays = Agrostis castellana $>$ Lolium boucheanum $>$ Lolium perenne $>$ Bromus sitchensis $=$ Bromus stamineus $=$ Phleum pratense $>$ Bromus inermis $>$ Panicum miliaceum.

Os estudos genéticos da tolerância ao alumínio em sua maioria foram realizados utilizando-se plantas de trigo (Silva, 1976; Lafever et al., 1978; Aniol, 1984; Delhaize \& Ryan, 1995). É provável que a tolerância seja governada por genes que agem através de várias rotas bioquímicas. Os mecanismos fisiológicos responsáveis pela tolerância ao alumínio parecem ser controlados geneticamente por um ou dois pares de genes dominantes em cevada (Foy, 1983) ou via alelos múltiplos no caso do milho (Rhue et al., 1978).

Foy (1988) propôs uma classificação dos mecanismos possivelmente relacionados à tolerância ao alumínio: a) mecanismos de exclusão: imobilização de Al na parede celular; permeabilidade seletiva da membrana plasmática; barreira de $\mathrm{pH}$ induzida na rizosfera; exsudação de compostos quelantes; b) mecanismos de tolerância interna: complexação ou quelação no citoplasma; compartimentação no vacúolo; proteínas especializadas na ligação com alumínio e evolução de enzimas tolerantes ao alumínio.

Em revisão recente, Kochian (1995) mencionou que a resistência ao alumínio pode ser dividida em dois grupos: 1) mecanismos de exclusão, os que excluem o alumínio tóxico do ápice radicular e, 2) mecanismos de tolerância, os que conferem habilidade às plantas suportarem o alumínio presente no simplasto. Os mecanismos de exclusão de alumínio pelos ápices radiculares têm sido mais estudados e incluem as estratégias como elevação do $\mathrm{pH}$ da rizosfera, imobilização do alumínio na parede celular, liberação de ácidos orgânicos e efluxo de $\mathrm{Al}^{3+}$ através da membrana plasmática (Delhaize \& Ryan, 1995; Kochian, 1995) e exclusão de fosfato (Pellet et al., 1996). 
Outros autores associam a tolerância diferencial com a capacidade de absorção, transporte e acúmulo de alumínio pelas plantas (Foy et al., 1967). Alguns genótipos tolerantes mostram redução na absorção desse elemento ou então imobilizam-no após a absorção (Foy et al., 1978). Calbo \& Cambraia (1980) verificaram que cultivares de sorgo tolerantes ao alumínio acumulam quantidades consideráveis de alumínio no protoplasma das células das raízes, o que indica a existência de um possível mecanismo interno de desintoxicação. Aniol (1984) observou que a tolerância ao alumínio por plantas de trigo era inibida quando as mesmas eram tratadas com ciclohexamida, sugerindo que em tais plantas há síntese induzida de uma proteína que se liga ao alumínio e impede sua ação nociva. Basu et al. (1994) descreveram duas formas de uma proteína denominada RMP51, presentes na fração microssomal de células do ápice radicular, as quais foram induzidas no cultivar de trigo tolerante ao alumínio e não sintetizadas pelo cultivar sensível. Todavia, Carver \& Ownby (1995) alertaram que ainda faltam comprovações para afirmar a existência de uma proteína indutora de tolerância ao alumínio. 


\section{MATERIAL E MÉTODOS}

\subsection{Seleção de genótipos de Panicum maximum para a tolerância ao alumínio}

Os experimentos para a seleção de genótipos de Panicum maximum para tolerância ao alumínio foram realizados em câmara-de-crescimento localizada no Setor de Nutrição Mineral de Plantas, do Departamento de Química, da Escola Superior de Agricultura "Luiz de Queiroz" - USP.

A câmara-de-crescimento possui área total de $16,2 \mathrm{~m}^{2}$, as paredes pintadas com tinta aluminizada e bancada de $7,2 \mathrm{~m}^{2}$ iluminada pela combinação de 72 lâmpadas fluorescentes de $50 \mathrm{~W}$ e 28 lâmpadas de vapor de mercúrio de $250 \mathrm{~W}$. A intensidade luminosa média foi de $208 \mu \mathrm{E} \mathrm{m}^{-2} \mathrm{~s}^{-1}$ e o ciclo de iluminação foi de 16 horas de claro e 8 horas de escuro, controlado através de temporizador. A temperatura do ambiente da câmara foi controlada através de dois condicionadores de ar frio/quente com capacidades para 17000 e 18000 BTU. O funcionamento desses dois condicionadores acompanhava o ciclo de iluminação, sendo ligados 30 minutos antes do início do período luminoso e desligados 30 minutos após o início do período escuro, ajustando temperaturas a $32^{\circ} \pm 2^{\circ} \mathrm{C}$ e $20^{\circ} \pm 2^{\circ} \mathrm{C}$, nos respectivos períodos. A umidade relativa média foi de $70 \pm 5 \%$ e $90 \pm 5 \%$ para os períodos claro e escuro, respectivamente.

Foram realizados experimentos prévios a fim de adequar as condições de funcionamento da câmara-de-crescimento e a metodologia de trabalho no que se refere ao número de dias após a germinação das sementes para o transplante para 
a solução nutritiva, adaptação de bandejas ao tamanho das plantas, controles da umidade relativa e da temperatura da câmara-de-crescimento.

\subsubsection{Genótipos de Panicum maximum e obtenção das mudas}

Foram utilizadas sementes de 24 acessos de Panicum maximum (Quadro 1) provenientes do programa de avaliação e seleção do CNPGC EMBRAPA e de seis cultivares comerciais: Centauro, Centenário, Colonião, Colonião IZ-1, Tobiatã e Vencedor. As sementes fornecidas pelo CNPGC provêm do banco de germoplasma de Panicum maximum que é constituído por 843 acessos genéticos, sendo que estes 24 acessos foram selecionados como promissores após avaliações em diversas regiões do brasileiras.

Antes da semeadura, procedeu-se à seleção das sementes em separador pneumático (assoprador), seguida de desinfecção superficial através de tratamento com Rhodiauran $\left(0,1 \mathrm{~g} \mathrm{~L}^{-1}\right)$. As sementes foram colocadas para germinar em gerbox sobre papel de filtro umedecido com solução $\mathrm{KNO}_{3}$ a $10 \mathrm{~g} \mathrm{~L}^{-1} \%$, na proporção de 2,5 mL por grama de papel. Em seguida foram mantidas por oito dias em germinador, com alternância de claro e escuro $(8 / 16 \mathrm{~h})$ e de temperatura $\left(30 / 20^{\circ} \mathrm{C}\right)$.

Após a emergência das plântulas realizou-se a medida do comprimento inicial da raiz seminal (CIRS), e aquelas uniformes em tamanho foram transplantadas para solução nutritiva sem alumínio, onde permaneceram por 24 horas. Passado esse período, as doses de alumínio foram aplicadas. 
Tabela 1 - Acessos de Panicum maximum com seus respectivos códigos no ORSTOM* e SNPA**

\begin{tabular}{c|c}
\hline \multicolumn{2}{c}{ Acessos de Panicum maximum } \\
\hline Código ORSTOM & Código SNPA \\
\hline K64 & BRA 006319 \\
K68 & BRA 006343 \\
K190A ${ }^{(1)}$ & BRA 006645 \\
K191 & BRA 006661 \\
K193 & BRA 006670 \\
K214 & BRA 006785 \\
K217 & BRA 006815 \\
K249 & BRA 006998 \\
T21 & BRA 007102 \\
T24 & BRA 007129 \\
T46 & BRA 007170 \\
T58 & BRA 007218 \\
T60 & BRA 007234 \\
T62 & BRA 007251 \\
T72 & BRA 007307 \\
T77 & BRA 007331 \\
T84 & BRA 007366 \\
T91 & BRA 007412 \\
T95 & BRA 007439 \\
T97 & BRA 007455 \\
T110 & BRA 007528 \\
KK8 & BRA 007609 \\
KK10 & BRA 007617 \\
KK33 & BRA 007731 \\
\hline
\end{tabular}

*ORSTOM $=$ Institute Français de Recherche Scientifique et Developpment en Coopération.

**SNPA $=$ Sistema Nacional de Pesquisa Agropecuária.

(1) Acesso lançado no Brasil em 1993 como cultivar Mombaça.

(2) Acesso lançado no Brasil em 1990 como cultivar Tanzânia-1. 


\subsubsection{Sistema de sustentação das plantas}

Devido ao tamanho reduzido das plantas, desenvolveu-se um sistema para a sustentação das mesmas sobre a solução nutritiva baseando-se no modelo utilizado por Polle et al. (1978). O sistema de sustentação (Figura 1) consistiu de bandeja de isopor $(28 \mathrm{~cm} \times 21 \mathrm{~cm} \times 3,5 \mathrm{~cm})$ com fundo em tela de náilon. $\mathrm{O}$ sistema foi colocado sobre bandejas plásticas, com capacidade para dez litros de solução nutritiva. A tensão entre o sistema e a solução permitiu que as plantas colocadas sobre a tela plástica tivessem contato ajustado com a solução nutritiva, tomando-se o devido cuidado para evitar que a parte aérea da planta fosse molhada pela solução. Cada célula do sistema recebeu uma planta.

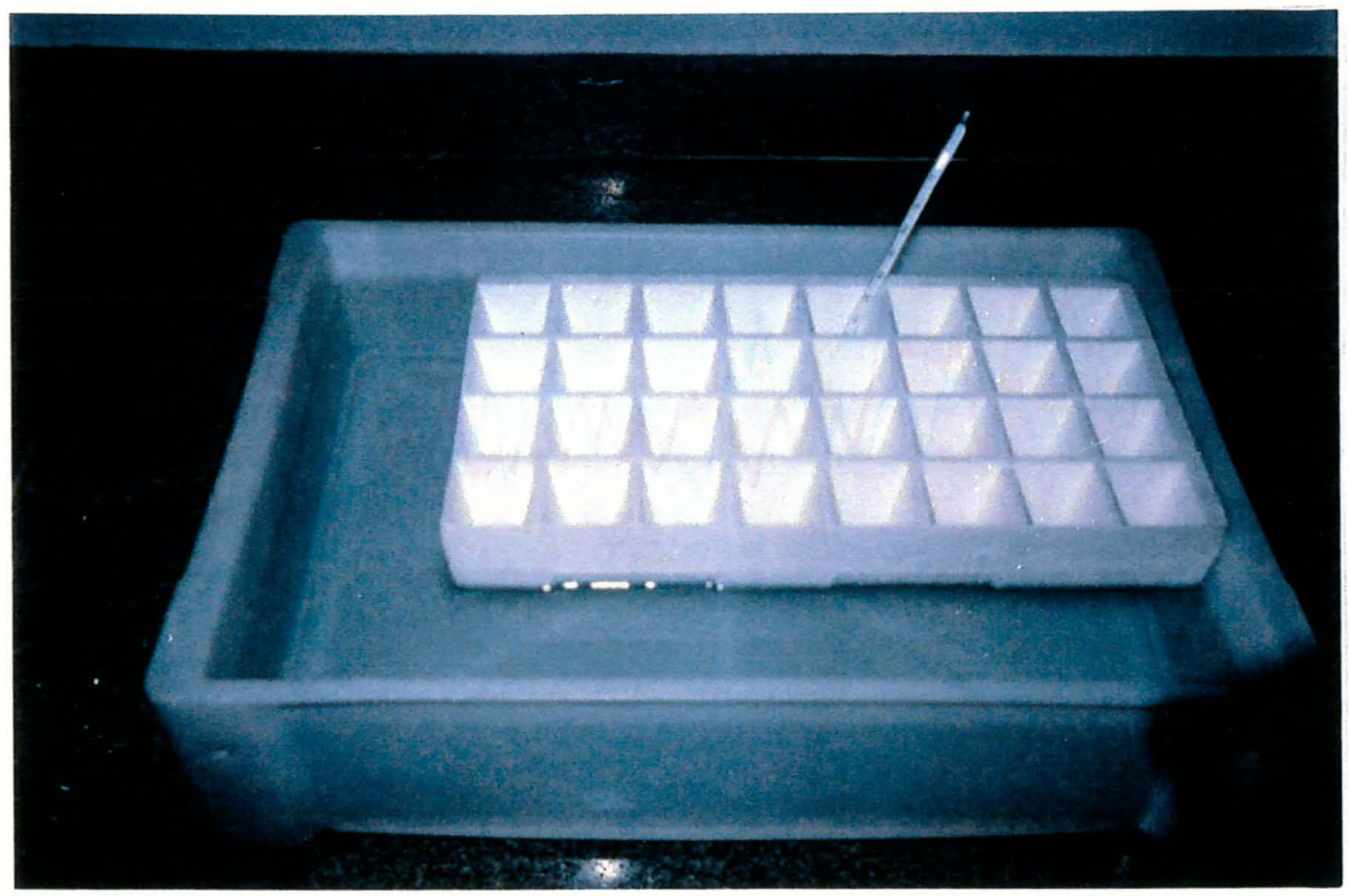

Figura 1 - Sistema de sustentação das plantas 


\subsubsection{Solução nutritiva}

Utilizou-se a solução nutritiva descrita por Furlani \& Furlani (1988) para estudo da tolerância ao alumínio em plantas de milho (Quadro 1). A solução estoque de alumínio foi preparada com $\mathrm{AlCl}_{3}$. $6 \mathrm{H}_{2} \mathrm{O}$ e as doses de alumínio empregadas foram 0,12 e $24 \mathrm{mg}$ de $\mathrm{Al} \mathrm{L}^{-1}$ de solução.

$\mathrm{O}$ pH das soluções foi ajustado em $4,2 \pm 0,1$, não sendo corrigido posteriormente, havendo apenas o seu registro diário. A aeração das soluções foi realizada através de bombas de ar para aquários.

Quadro 1 - Composição das soluções-estoque e da solução nutritiva empregadas no estudo de tolerância de plantas de Panicum maximum ao alumínio, segundo Furlani \& Furlani (1988).

\begin{tabular}{|c|c|c|c|c|}
\hline \multicolumn{3}{|c|}{ Soluções Estoque } & \multicolumn{2}{|c|}{ Solução nutritiva } \\
\hline $\mathrm{n}^{\circ}$ & Sais & $\begin{array}{l}\text { Concentração } \\
\left(\mathrm{g} \mathrm{L}^{-1}\right)\end{array}$ & $\begin{array}{l}\text { solução estoque/ } \\
\text { água }\left(\mathrm{mL} \mathrm{L}^{-1}\right)\end{array}$ & $\begin{array}{l}\text { Concentração } \\
\text { final }\left(\mathrm{mg} \mathrm{L}^{-1}\right)\end{array}$ \\
\hline 1 & $\begin{array}{c}\mathrm{Ca}\left(\mathrm{NO}_{3}\right)_{2} .4 \mathrm{H}_{2} \mathrm{O} \\
\mathrm{NH}_{4} \mathrm{NO}_{3}\end{array}$ & $\begin{array}{c}270,0 \\
33,8\end{array}$ & 3,1 & $\begin{aligned} \mathrm{Ca} & =142 \\
\mathrm{~N}-\mathrm{NO}_{3}{ }^{-} & =150\end{aligned}$ \\
\hline 2 & $\begin{array}{c}\mathrm{KCl} \\
\mathrm{K}_{2} \mathrm{SO}_{4} \\
\mathrm{KNO}_{3}\end{array}$ & $\begin{array}{l}18,6 \\
44,0 \\
24,6\end{array}$ & 2,2 & $\begin{array}{r}\mathrm{N}^{-\mathrm{NH}_{4}{ }^{+}}=18 \\
\mathrm{~K}=87 \\
\mathrm{P}=1\end{array}$ \\
\hline 3 & $\mathrm{Mg}\left(\mathrm{NO}_{3}\right)_{2} .6 \mathrm{H}_{2} \mathrm{O}$ & 142,6 & 1,6 & $\mathrm{Mg}=22$ \\
\hline 4 & $\mathrm{KH}_{2} \mathrm{PO}_{4}$ & 17,6 & 0,5 & $S=21$ \\
\hline 5 & $\begin{array}{c}\mathrm{FeSO}_{4} .7 \mathrm{H}_{2} \mathrm{O} \\
\mathrm{Na}_{2} \text { EDTA }\end{array}$ & $\begin{array}{l}24,9 \\
29,6\end{array}$ & 0,6 & $\begin{array}{r}\mathrm{Fe}=5 \\
\mathrm{Mn}=0,39\end{array}$ \\
\hline 6 & $\begin{array}{c}\mathrm{MnCl}_{2} \cdot 4 \mathrm{H}_{2} \mathrm{O} \\
\mathrm{H}_{3} \mathrm{BO}_{3} \\
\mathrm{ZnSO}_{4} \cdot 7 \mathrm{H}_{2} \mathrm{O} \\
\mathrm{CuSO}_{4} .5 \mathrm{H}_{2} \mathrm{O} \\
\mathrm{Na}_{2} \mathrm{MoO}_{2} \cdot 2 \mathrm{H}_{2} \mathrm{O}\end{array}$ & $\begin{array}{l}2,34 \\
2,04 \\
0,88 \\
0,20 \\
0,26\end{array}$ & 0,6 & $\begin{array}{rl}\mathrm{Cl} & * \\
\mathrm{~B} & =0,22 \\
\mathrm{Zn} & =0,12 \\
\mathrm{Cu} & =0,03 \\
\mathrm{Mo} & =0,07 \\
\mathrm{Na} & =0,02\end{array}$ \\
\hline
\end{tabular}

* Devido a adição de alumínio na forma de $\mathrm{AlCl}_{3} \cdot 6 \mathrm{H}_{2} \mathrm{O}$ a concentração final de cloro foi de: 20 ,

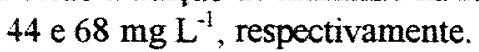




\subsubsection{Avaliação do crescimento da raiz seminal}

Para testar os 30 genótipos de Panicum maximum quanto ao crescimento da raiz seminal em função de doses de alumínio, foram realizados quatro experimentos na câmara-de-crescimento. A necessidade de se fazer experimentos em separados foi decorrente da limitação de material para a germinação das sementes. Em cada experimento, com exceção do segundo, foram estudados oito genótipos, sendo que o cultivar comercial Colonião foi incluído em todos os experimentos como testemunha (Tabela 2).

Tabela 2 - Genótipos de Panicum maximum empregados nos experimentos para avaliação do crescimento da raiz seminal.

\begin{tabular}{cccc}
\hline & \multicolumn{4}{c}{ EXPERIMENTOS } \\
I & II & III & IV \\
\hline Colonião & Colonião & Genótipos & Colonião \\
K191 & Tobiatã & Centauro & K214 \\
K217 & K193 & Centenário & K249 \\
KK10 & T21 & IZ-1 & T62 \\
KK33 & T24 & K68 & T72 \\
KK8 & T60 & Mombaça & T95 \\
T46 & T64 & T84 & Tanzânia-1 \\
T91 & T77 & T110 & Vencedor \\
& T97 & & \\
\hline
\end{tabular}

Antes do transplante realizou-se a medida do comprimento inicial da raiz seminal (CIRS) e 96 horas depois, ou seja 72 horas após a aplicação das doses de alumínio, mediu-se o comprimento final da raiz seminal (CFRS). A diferença entre essas medidas resultou no crescimento da raiz seminal (CRS).

A partir destes parâmetros estimou-se comprimento relativo da raiz seminal (CRRS) e a inibição do alongamento radicular (I) da seguinte forma: 


$$
\begin{aligned}
& \text { CRRS }=\left[\left(\frac{\mathrm{CFRS}}{\mathrm{CIRS}}\right)-1\right] \times 100 \quad \text { Parentoni et al., } 1996 \\
& \mathrm{I}=\left[1-\left(\frac{\mathrm{CRRS}_{+\mathrm{Al}}}{\mathrm{CRRS}_{-\mathrm{Al}}}\right)\right] \times 100
\end{aligned}
$$

onde $\mathrm{CRRS}_{+\mathrm{Al}}$ é o comprimento relativo da raiz seminal das plantas crescidas na presença de alumínio e CRRS $_{\text {-Al }}$ o comprimento relativo da raiz seminal das plantas crescidas na ausência de alumínio.

Estimou-se também o índice de tolerância ao alumínio (ITR-Al):

$$
\text { ITR }-\mathrm{Al}=\left[\left(\frac{\mathrm{CRR}_{\mathrm{X}}-\mathrm{CRR}_{\mathrm{S}}}{\mathrm{CRR}_{\mathrm{T}}-\mathrm{CRR}_{\mathrm{S}}}\right) \mathrm{x} 4\right]+1 \quad \text { Furlani \& Furlani (1991) }
$$

onde CRR é a relação entre os valores de crescimento da raiz seminal (CRS) das plantas crescidas na presença de alumínio $\left(\mathrm{CRS}_{+\mathrm{Al}}\right)$ e na ausência de alumínio

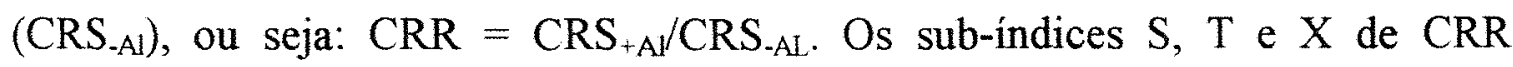
correspondem, respectivamente, aos valores obtidos para os genótipos: referência sensivel (capim-centauro), referência tolerante (capim-centenário) e em estudo.

\subsubsection{Delineamento experimental e análises estatísticas}

Empregou-se o delineamento experimental em blocos ao acaso, em esquema de parcelas subdivididas, com cinco repetições. As parcelas constituíram as doses de alumínio (3) e as sub-parcelas os genótipos (8 ou 9), sendo que para cada sub-parcela foram utilizadas seis plantas. 
Os resultados das avaliações do crescimento da raiz seminal foram submetidos à análise de variância (teste $\mathrm{F}$ ). Em caso do valor de $\mathrm{F}$ calculado significativo realizou-se o teste de comparação de médias entre os genótipos (Tukey a 5\% de significância) e regressão polinomial para as doses de alumínio.

Para o índice de tolerância ao alumínio (ITR-Al) e inibição do alongamento da raiz seminal (I), realizou-se a comparação entre os genótipos com base no intervalo de confiança para as médias em uma distribuição " $\mathrm{t}$ ": $\mathrm{s} \bar{x} \cdot \mathrm{t}$ $(0,05 ; n-1) \cdot$

Os cálculos foram efetuados através do aplicativo estatístico "SASSystem for Windows 95-release 6.11" (SAS Institute Inc., 1996).

\subsection{Influência do alumínio em três genótipos de Panicum maximum com tolerância diferencial}

Este experimento foi realizado em casa-de-vegetação localizada no Setor de Nutrição Mineral de Plantas, do Departamento de Química, da Escola Superior de Agricultura "Luiz de Queiroz"-USP.

A partir dos resultados dos experimentos de seleção realizados em câmara-de-crescimento (item 3.1), foram selecionados três dos genótipos Panicum maximum, ou sejam, aquele que se mostrou mais tolerante, o moderadamente tolerante e o mais sensível ao alumínio, para avaliação do efeito de doses de alumínio no crescimento, nas atividades das enzimas redutase do nitrato e fosfatase ácida e na nutrição mineral desses capins.

\subsubsection{Obtenção das mudas e condução do experimento}

As sementes foram germinadas conforme descrito em 3.1.1. No oitavo dia pós-semeadura dez mudas foram transplantadas para vasos plásticos, com 
volume de 3,6 L, preenchidos com sílica. Foram realizados desbastes após uma semana do transplante, de forma que em cada vaso permaneceram quatro plantas.

Aos vasos adicionou-se a solução nutritiva correspondente a cada dose de alumínio e essa solução foi circulada diariamente através da sílica. A solução permaneceu no vaso durante o dia, sendo drenada à noite e renovada a cada cinco dias. A solução nutritiva empregada foi a mesma descrita anteriormente (Quadro 1), modificada apenas quanto à concentração de fósforo, a qual foi elevada para $2 \mathrm{mg} \mathrm{L}^{-1}$. Nos primeiros cinco dias pós-transplante as plantas receberam a solução nutritiva sem alumínio, e na primeira troca de solução nutritiva realizou-se a aplicação das doses de alumínio, as quais foram de $0 ; 6$; $12 ; 24$ e $36 \mathrm{mg} \mathrm{L}^{-1}$ de solução.

Aos 30 dias após o transplante efetuou-se a contagem do número de perfilhos e o corte das plantas, que foram separadas em lâminas foliares, colmos + bainhas e raízes.

O material vegetal colhido foi colocado em sacos de papel e levado para secagem em estufa de circulação forçada de ar a $65^{\circ} \mathrm{C}$ até massa constante. Em seguida o material foi pesado e moído.

\subsubsection{Determinações efetuadas no material vegetal}

\subsubsection{Perfilhamento, volume radicular, rendimento de matéria seca e composição mineral}

No dia do corte das plantas efetuou-se a contagem do número total de perfilhos por vaso, bem como a determinação do volume do sistema radicular. A aferição do volume do sistema radicular foi realizada pela imersão do sistema radicular, previamente secado em papel toalha, das quatro plantas do vaso, em uma proveta com volume conhecido de água (Fernandes et al., 1984). 
Quanto ao rendimento da matéria seca, as massas da matéria seca das lâminas foliares e colmos + bainhas foram somadas para a obtenção da matéria seca da parte aérea da planta.

No material vegetal seco e moído determinou-se a concentração de nitrogênio, fósforo, potássio, cálcio, magnésio e alumínio, conforme metodologia descrita por Sarruge \& Haag (1974).

\subsubsection{Atividade da redutase do nitrato}

Aos 15 dias pós-transplante realizou-se a determinação da atividade da redutase do nitrato (E.C. 1.6.6.1) através do método descrito por Mulder et al. (1959). Antes da determinação propriamente dita, as plantas foram mantidas por duas horas sob iluminação artificial na câmara-de-crescimento, após o que cortouse uma porção de $200 \mathrm{mg}$ da lâmina foliar de cada uma das duas folhas que recentemente se tornaram completamente expandidas, de uma planta para cada dose de alumínio e cada genótipo. As folhas cortadas foram transferidas para tubos de ensaio contendo $4 \mathrm{~mL}$ de $\mathrm{KNO}_{3} 0,25 \mathrm{~mol} \mathrm{~L}^{-1}$ em tampão fosfato $\mathrm{pH} \mathrm{7,4}$ e incubadas em banho-maria a $30^{\circ} \mathrm{C}$ por duas horas, ao abrigo de luz. Em seguida retirou-se uma alíquota de $1 \mathrm{~mL}$ do meio de reação e adicionou-se $1 \mathrm{~mL}$ de ácido sulfanílico $\left(10 \mathrm{~g} \mathrm{~L}^{-1}\right.$ em $\left.\mathrm{HCl} 2 \mathrm{~N}\right)$ e $1 \mathrm{~mL}$ de $\alpha$-naftilamina $0,5 \mathrm{~g} \mathrm{~L}^{-1}$. O $\mathrm{NO}_{2}$ formado durante a incubação foi determinado por colorimetria a $540 \mathrm{~nm}$. Os resultados foram expressos em $\mu \mathrm{mol}$ de $\mathrm{NO}_{2} \mathrm{~h}^{-1} \mathrm{~g}^{-1}$ de tecido vivo.

\subsubsection{Atividade da fosfatase ácida}

A atividade da enzima fosfatase ácida (E.C. 3.1.3.4.1) foi determinada, segundo o método descrito por Basso \& Silva (1992), paralelamente à atividade da redutase do nitrato. Nessa avaliação foram utilizados $100 \mathrm{mg}$ de lâmina foliar, 
das folhas recém-expandidas, conforme descrito para a atividade da redutase do nitrato. Esse material foi adicionado a tubo de ensaio contendo $8 \mathrm{~mL}$ de paranitrofenil fosfato (p-NPP) $250 \mu \mathrm{mol} \mathrm{L} \mathrm{L}^{-1}$ em tampão acetato de sódio $\mathrm{pH} 4 \mathrm{e}$ mantido em banho-maria a $30^{\circ} \mathrm{C}$, ao abrigo de luz. Após duas horas foi retirada uma amostra de $5 \mathrm{~mL}$ do meio de reação, à qual se adicionou $2 \mathrm{~mL}$ de $\mathrm{NaOH} 2 \mathrm{~N}$. A concentração de para-nitrofenol ( $p-N P$ ) formado foi determinada por colorimetria usando comprimento de onda de $420 \mathrm{~nm}$. Os valores foram expressos em $\mu \mathrm{mol} \mathrm{h}{ }^{-1} \mathrm{~g}^{-1}$ de para-nitrofenol no tecido vivo.

\subsubsection{Delineamento experimental e análise estatística}

O delineamento empregado neste estudo foi o de blocos ao acaso, em esquema fatorial $3 \times 5$, isto é, três genótipos e cinco doses de alumínio, com cinco repetições. Os resultados foram submetidos à análise de variância (teste $F$ ) e, em caso de $F$ calculado significativo realizou-se a análise de regressão polinomial para as doses de alumínio e o teste de Tukey para a comparação entre médias dos genótipos. 


\section{RESULTADOS E DISCUSSÃO}

\subsection{Experimentos de seleção de genótipos de Panicum maximum para a tolerância ao alumínio}

\subsubsection{Crescimento da raiz seminal (CRS)}

Quanto ao crescimento da raiz seminal (CRS) a análise de variância evidenciou efeito significativo $(\mathrm{P}<0,05)$ para a interação genótipos $\mathrm{x}$ doses de alumínio, com exceção dos resultados do experimento IV. As interações significativas nos experimentos I (Tabela 3), II (Tabela 4) e III (Tabela 5) foram desdobradas, fixando-se a dose de alumínio, para avaliar o comportamento dos genótipos. A comparação das médias para genótipos também foi efetuada no experimento IV.

Na Tabela 3 verifica-se que na omissão de alumínio os genótipos K191, K217, T46 e KK10 apresentaram crescimento da raiz seminal (CRS) superior ao $\mathrm{KK} 33$. Ainda na dose $0 \mathrm{mg}$ de $\mathrm{Al} \mathrm{L}^{-1}$, o CRS do capim-colonião, genótipo utilizado como referência, não diferiu dos demais genótipos avaliados. Na dose $12 \mathrm{mg}$ de Al L ${ }^{-1}$ observa-se que o genótipo K191 apresenta maior CRS que KK33, Colonião e T46. Com relação à dose $24 \mathrm{mg}$ de $\mathrm{Al} \mathrm{L}^{-1}$ os genótipos K191, K217 e T91 foram superiores aos demais genótipos estudados. Na presença de alumínio os genótipos K191 e K217 sempre se mantiveram no grupo estatístico superior, destacando-se o K191 que apresentou maior CRS médio. A dose $24 \mathrm{mg}$ de $\mathrm{Al} \mathrm{L}^{-1}$ possibilitou a estratificação dos genótipos em grupos de tolerância, ou seja, aqueles mais tolerantes (K191, K217 e T91) e os mais sensíveis (Colonião, 
KK10, KK33, KK8 e T46). Este resultado corrobora a afirmação de Usberti Filho et al. (1987), que apontaram a dose $24 \mathrm{mg}$ de $\mathrm{Al} \mathrm{L}^{-1}$ como aquela que possibilitou boa separação de híbridos e cultivares de capim-colonião quanto à tolerância ao alumínio.

Na Figura 2 são apresentadas as equações de regressão polinomial para o efeito das doses de alumínio dentro de cada genótipo. O genótipo adotado como referencial, o cultivar comercial Colonião, apresentou redução linear no CRS com o aumento da dose de alumínio na solução nutritiva. Decréscimos semelhantes foram também verificados para os genótipos KK10 e T46. O CRS dos capins K217, KK33, KK8 e T91 também foi alterado pela adição de alumínio, sendo representados por modelos quadráticos (com predominância de redução no CRS, na faixa estudada). Em contrapartida, o genótipo K191 apresentou variação ajustada à equação do segundo grau, mostrando aumento no CRS em função da adição de alumínio na solução, com valor máximo na dose $14,8 \mathrm{mg}$ de $\mathrm{Al} \mathrm{L}^{-1}$.

Tabela 3 - Crescimento da raiz seminal (CRS) de plantas de Panicum maximum submetidas a doses de alumínio no experimento I, em câmara-decrescimento.

\begin{tabular}{c|ccc}
\hline \multirow{2}{*}{ Genótipos } & \multicolumn{3}{|c}{ CRS (cm) } \\
\cline { 2 - 4 } & 0 & Al $\left(\mathrm{mg} \mathrm{L}^{-1}\right)$ & 24 \\
\hline Colonião & $0,7 \mathrm{ab}$ & $0,4 \mathrm{~b}$ & $0,3 \mathrm{~b}$ \\
K191 & $0,8 \mathrm{a}$ & $1,3 \mathrm{a}$ & $1,1 \mathrm{a}$ \\
K217 & $1,3 \mathrm{a}$ & $0,8 \mathrm{ab}$ & $0,9 \mathrm{a}$ \\
VKK10 & $0,8 \mathrm{a}$ & $0,6 \mathrm{ab}$ & $0,5 \mathrm{~b}$ \\
KK33 & $0,5 \mathrm{~b}$ & $0,3 \mathrm{~b}$ & $0,3 \mathrm{~b}$ \\
KK8 & $0,6 \mathrm{ab}$ & $0,6 \mathrm{ab}$ & $0,3 \mathrm{~b}$ \\
T46 & $1,0 \mathrm{a}$ & $0,5 \mathrm{~b}$ & $0,4 \mathrm{~b}$ \\
T91 & $0,7 \mathrm{ab}$ & $0,7 \mathrm{ab}$ & $0,6 \mathrm{a}$ \\
\hline C.V. genótipo & 26,24 & 26,80 & 25,96 \\
C.V. doses de Al & 30,27 & & \\
\hline
\end{tabular}

Médias seguidas de mesma letra, minúscula em cada coluna, não diferem pelo teste de Tukey $(\mathrm{P}>0,05)$ 

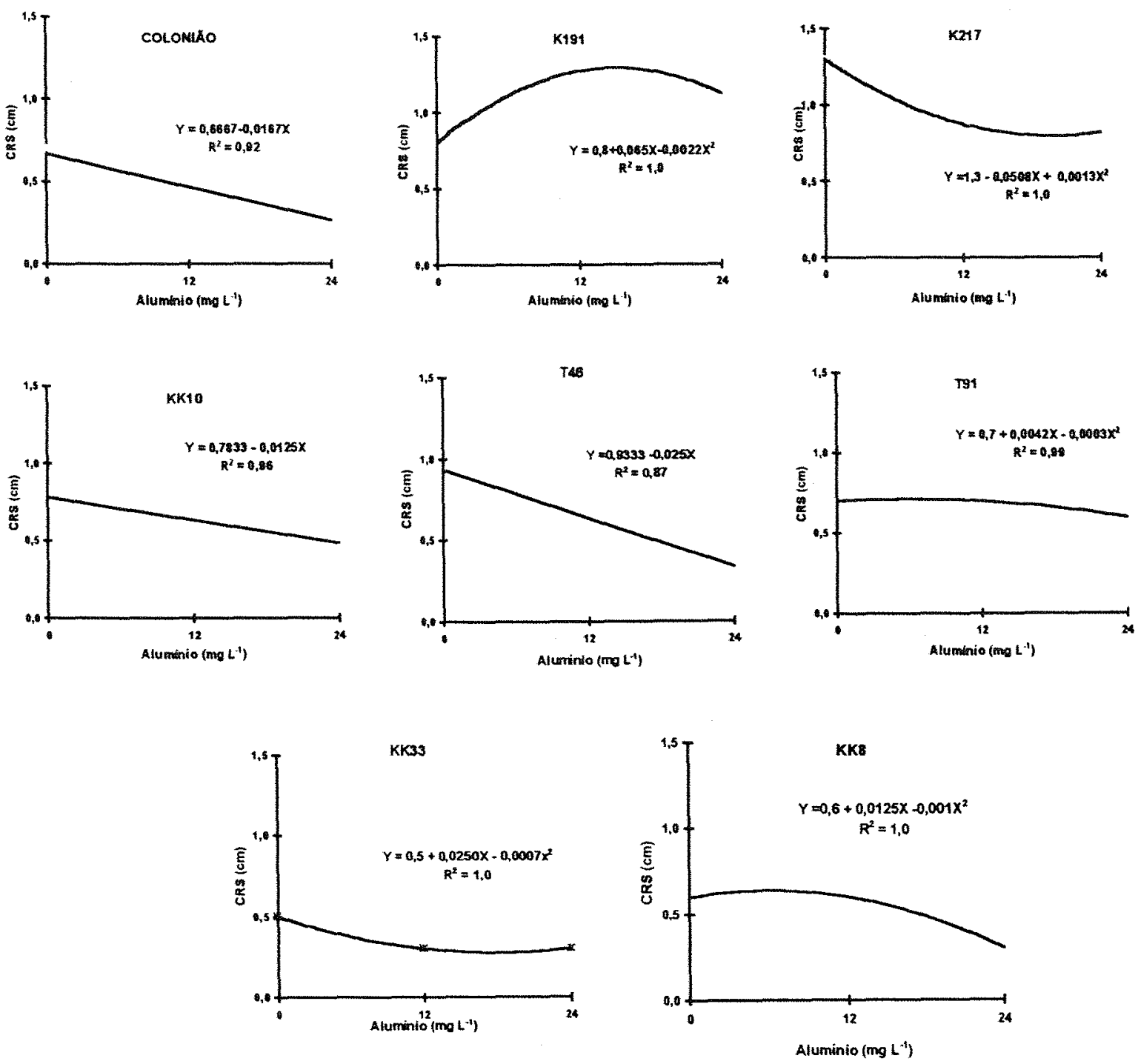

Figura 2 - Crescimento da raiz seminal (CRS) de genótipos de Panicum maximum submetidas a doses de alumínio no experimento I, em câmara-decrescimento. 
Em relação ao desempenho dos genótipos avaliados no experimento II (Tabela 4) nota-se que nas três doses de alumínio o teste de Tukey não detectou diferenças significativas $(P>0,05)$ entre os genótipos.

Tabela 4 - Crescimento da raiz seminal (CRS) de plantas de Panicum maximum submetidas a doses de alumínio no experimento II, em câmara-decrescimento.

\begin{tabular}{c|ccc}
\hline \multirow{3}{*}{ Genótipos } & \multicolumn{3}{|c}{ CRS $(\mathrm{cm})$} \\
\cline { 2 - 4 } & 0 & $\mathrm{Al}\left(\mathrm{mg} \mathrm{L}^{-1}\right)$ & 24 \\
\hline Colonião & $0,8 \mathrm{a}$ & $0,5 \mathrm{a}$ & $0,4 \mathrm{a}$ \\
Tobiatã & $1,2 \mathrm{a}$ & $0,7 \mathrm{a}$ & $0,4 \mathrm{a}$ \\
K193 & $0,8 \mathrm{a}$ & $0,5 \mathrm{a}$ & $0,6 \mathrm{a}$ \\
T21 & $0,9 \mathrm{a}$ & $0,8 \mathrm{a}$ & $0,7 \mathrm{a}$ \\
T24 & $0,9 \mathrm{a}$ & $0,6 \mathrm{a}$ & $0,6 \mathrm{a}$ \\
T60 & $0,9 \mathrm{a}$ & $0,8 \mathrm{a}$ & $0,5 \mathrm{a}$ \\
T64 & $0,8 \mathrm{a}$ & $0,6 \mathrm{a}$ & $0,7 \mathrm{a}$ \\
T77 & $0,6 \mathrm{a}$ & $0,4 \mathrm{a}$ & $0,2 \mathrm{a}$ \\
T97 & $0,5 \mathrm{a}$ & $0,4 \mathrm{a}$ & $0,3 \mathrm{a}$ \\
\hline C.V. genótipo & 24,45 & 32,30 & 38,84 \\
C.V. doses de Al & 24,17 & & \\
\hline
\end{tabular}

Médias seguidas de mesma letra, minúscula em cada coluna, não diferem pelo teste de Tukey ( $\mathrm{P}>0,05)$

Com relação ao efeito das doses de alumínio dentro de cada genótipo a análise de regressão mostrou ajuste aos modelos matemáticos lineares, exceto para o genótipo K193 (que foi quadrático), os quais são ilustrados na Figura 3. Todos os genótipos mostraram redução significativa no CRS com o aumento da dose de alumínio na solução nutritiva. A magnitude da redução no CRS, para cada unidade de alumínio na solução, foi mais expressiva nos genótipos Tobiatã, Colonião, T60 e T77 (coeficientes de X iguais ou maiores que 0,0167 ). 

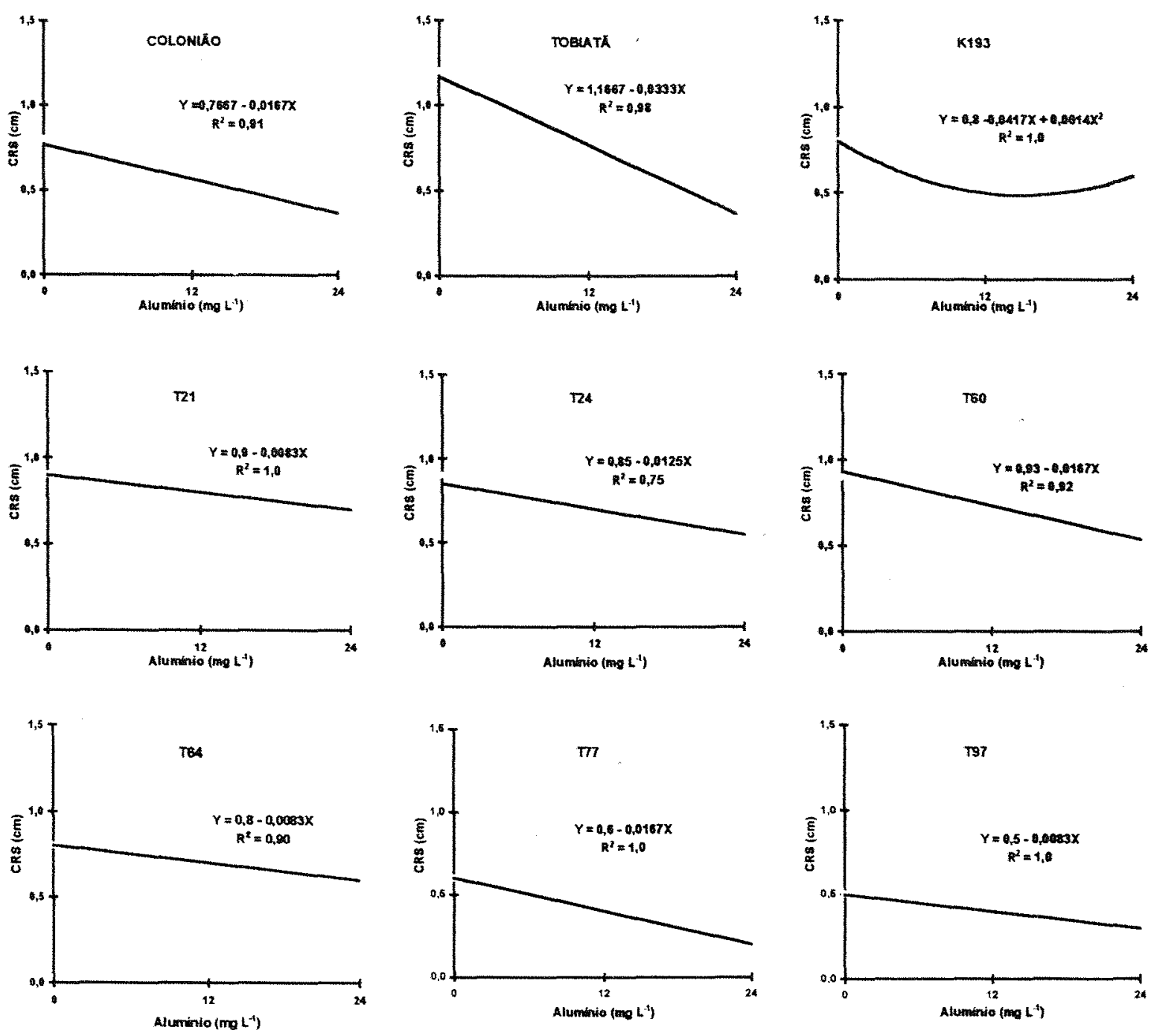

Figura 3- Crescimento da raiz seminal (CRS) de genótipos de Panicum maximum submetidas a doses de alumínio no experimento II, em câmara-decrescimento

Quanto à comparação dos genótipos dentro de cada dose de alumínio no experimento III (Tabela 5) verifica-se que na dose $0 \mathrm{mg} \mathrm{de} \mathrm{Al} \mathrm{L}^{-1}$ o genótipo IZ-1 apresentou CRS superior aos genótipos Centenário e T84. Na presença de alumínio, o teste de Tukey não evidenciou diferença significativa $(P>0,05)$ entre os genótipos. 
Fixando-se o genótipo, para o desdobramento da interação, o estudo do efeito das doses através de regressão polinomial mostrou que o incremento de alumínio na solução nutritiva promoveu decréscimos lineares no CRS dos genótipos IZ-1 e T110, e variações quadráticas em Colonião, Centauro, K68 e Mombaça. O cultivar Centenário apresentou elevação do CRS com o aumento da dose de alumínio, ajustando-se uma equação linear a esse comportamento. Verifica-se que o genótipo T84 não apresentou variação em seus valores de CRS, indicando não ser afetado pela presença de alumínio. Para os demais genótipos observa-se que houve redução do crescimento da raiz seminal (CRS) com a elevação da dose de alumínio na solução nutritiva, variando grandemente a magnitude da redução do alongamento radicular, de 0\% em T84 a 71\% em Centauro.

Tabela 5 - Crescimento da raiz seminal (CRS) de plantas de Panicum maximum submetidas a doses de alumínio no experimento III, em câmara-decrescimento.

\begin{tabular}{c|ccc}
\hline \multirow{2}{*}{ Genótipos } & \multicolumn{3}{c}{ CRS (cm) } \\
\cline { 2 - 4 } & 0 & $\mathrm{Al}\left(\mathrm{mg} \mathrm{L}^{-1}\right)$ & 24 \\
\hline Colonião & $0,8 \mathrm{ab}$ & $0,4 \mathrm{a}$ & $0,4 \mathrm{a}$ \\
Centauro & $0,7 \mathrm{ab}$ & $0,2 \mathrm{a}$ & $0,2 \mathrm{a}$ \\
Centenário & $0,5 \mathrm{~b}$ & $0,6 \mathrm{a}$ & $0,7 \mathrm{a}$ \\
IZ-1 & $1,2 \mathrm{a}$ & $0,7 \mathrm{a}$ & $0,5 \mathrm{a}$ \\
K68 & $0,8 \mathrm{ab}$ & $0,3 \mathrm{a}$ & $0,3 \mathrm{a}$ \\
Mombaça & $0,8 \mathrm{ab}$ & $0,7 \mathrm{a}$ & $0,5 \mathrm{a}$ \\
T84 & $0,4 \mathrm{~b}$ & $0,4 \mathrm{a}$ & $0,4 \mathrm{a}$ \\
T110 & $0,7 \mathrm{ab}$ & $0,4 \mathrm{a}$ & $0,4 \mathrm{a}$ \\
\hline C.V. genótipo & 26,24 & 26,80 & 25,96 \\
C.V. doses de Al & 30,27 & & \\
\hline
\end{tabular}

Médias seguidas de mesma letra, minúscula em cada coluna, não diferem pelo teste de Tukey $(\mathrm{P}>0,05)$ 

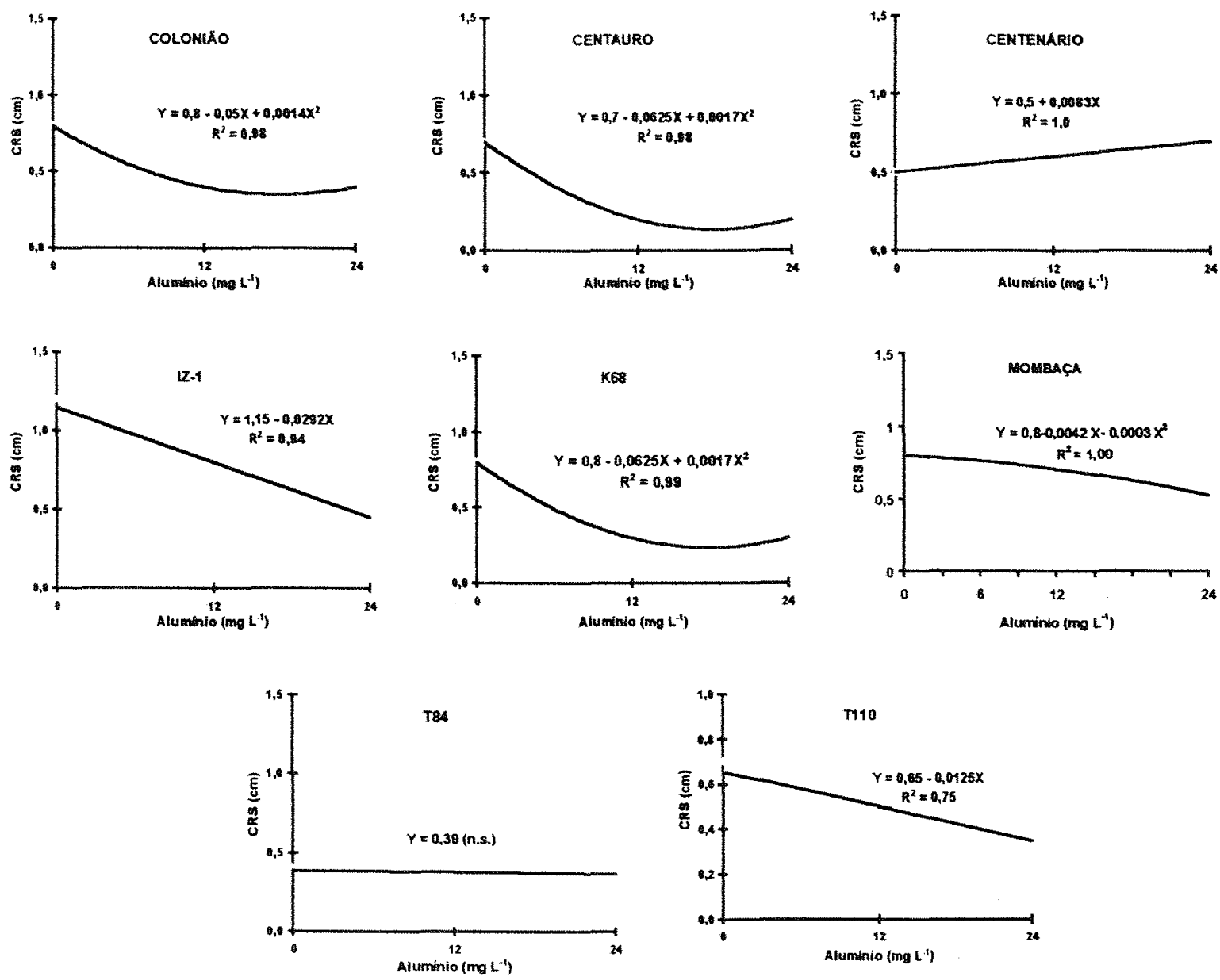

Figura 4 - Crescimento da raiz seminal (CRS) de genótipos de Panicum maximum submetidas a doses de alumínio no experimento III, em câmara-decrescimento.

Na Tabela 6 verifica-se que, na média dos genótipos, as doses de alumínio não influenciaram (Tukey a 5\% de significância) o CRS dos capins avaliados no experimento IV. A comparação entre os genótipos mostrou que, na média das doses, os genótipos Vencedor e T62 foram superiores em CRS ao T72. 
Tabela 6 - Crescimento da raiz seminal (CRS) de plantas de Panicum maximum submetidas a doses de aluminio no experimento IV, em câmara-decrescimento.

\begin{tabular}{c|ccc|c}
\hline \multirow{3}{*}{ Genótipos } & \multicolumn{3}{|c|}{ CRS (cm) } & \multirow{2}{*}{ Média } \\
\cline { 2 - 4 } & \multicolumn{3}{|c|}{$\mathrm{Al} \mathrm{( \textrm {mg } \mathrm { L } ^ { - 1 } )}$} & \\
\hline Colonião & 0 & 12 & 24 & $0,9 \mathrm{ab}$ \\
K214 & 1,3 & 1,0 & 0,5 & $1,2 \mathrm{ab}$ \\
K249 & 2,0 & 1,1 & 0,6 & $0,9 \mathrm{ab}$ \\
T62 & 1,6 & 0,6 & 0,6 & $1,5 \mathrm{a}$ \\
T72 & 1,9 & 1,3 & 1,2 & $0,6 \mathrm{~b}$ \\
T95 & 0,8 & 0,5 & 0,4 & $1,1 \mathrm{ab}$ \\
Tanzânia-1 & 0,7 & 1,2 & 1,4 & $0,9 \mathrm{ab}$ \\
Vencedor & 1,1 & 1,0 & 0,7 & $1,7 \mathrm{a}$ \\
\hline Média & 2,2 & 1,5 & 1,4 & \\
\hline
\end{tabular}

Médias seguidas de mesma letra, minúscula na coluna e maiúscula na linha, não diferem pelo teste de Tukey ( $\mathrm{P}>0$, 10)

Os genótipos K191 (Figura 2) e Centenário (Figura 4) apresentaram aumento significativo do crescimento da raiz seminal (CRS) com a adição de alumínio na solução nutritiva. Apesar da análise de variância não ter detectado significância para a interação entre genótipos e doses de alumínio, no experimento IV, pode-se notar na Tabela 6 que o genótipo T95 apresenta elevação no valor absoluto de CRS, com o aumento da dose de alumínio. Essa característica apresentada pelos genótipos K191, Centenário e, muito provavelmente, T95, é um indicativo importante no desenvolvimento de cultivares resistentes, pois revela o potencial de crescimento da raiz em condições de excesso de alumínio.

O efeito positivo do alumínio no crescimento de algumas plantas têm sido atribuído à ação nociva do próton $\mathrm{H}^{+}$presente na solução nutritiva. Foy (1983) relatou que esse efeito benéfico do alumínio é significativo nas plantas tolerantes ao $\mathrm{Al}^{3+}$. Estudando a tolerância ao alumínio em genótipos de aveia, Floss (1992) verificou que o crescimento da raiz seminal (CRS) do genótipo 
tolerante UPF86A1198-5-1b aumentava com o incremento de alumínio na solução nutritiva. Efeito semelhante foi verificado por Kinraide \& Parker (1990), que sugeriram estar a presença de alumínio minimizando o efeito tóxico dos prótons $\mathrm{H}^{+}$.

O crescimento da raiz seminal (CRS) foi um parâmetro com alta variação e esta, é poucas vezes ressaltada na literatura. Londoño \& Aristizábal (1983) verificaram altos coeficientes de variação em seu estudo de toxicidade de alumínio em plantas de café. Horst et al. (1997) sugeriram a determinação de calose nas raizes em estudos de tolerância ao alumínio, visto que o crescimento radicular é um parâmetro muito mais variável. Todavia, Floss (1992), trabalhando com plantas de aveia, obteve coeficientes de variação para o crescimento radicular mais baixos que os obtidos no presente estudo.

\subsubsection{Comprimento relativo da raiz seminal (CRRS)}

A análise de variância do comprimento relativo da raiz seminal (CRRS) mostrou significância $(\mathrm{P}<0,10)$ para a interação genótipo $\mathrm{x}$ doses de alumínio no experimento I, bem como para genótipos e para doses de alumínio nos experimentos II e III. O CRRS dos genótipos avaliados no experimento IV não apresentou variação significativa $(\mathrm{P}>0,05)$ para genótipos nem para as doses de alumínio (Tabela 10).

Na Tabela 7 verifica-se que na omissão de alumínio os genótipos K217, T46 e KK10 apresentaram comprimento relativo da raiz seminal (CRRS) superior ao KK8. Nas doses 12 e $24 \mathrm{mg}$ de $\mathrm{Al} \mathrm{L} \mathrm{L}^{-1}$ observa-se que o genótipo K191 apresenta maior CRRS que o capins Colonião, KK8 e T46. 
Tabela 7- Comprimento relativo da raiz seminal (CRRS) de plantas de Panicum maximum submetidas a doses de alumínio no experimento I, em câmara-decrescimento.

\begin{tabular}{c|ccc}
\hline \multirow{3}{*}{ Genótipos } & \multicolumn{3}{|c}{ CRRS (\%) } \\
\cline { 2 - 4 } & 0 & Al (mg L & \multicolumn{3}{c}{12} \\
\cline { 2 - 4 } & $43,3 \mathrm{ab}$ & $24,5 \mathrm{~b}$ & $21,1 \mathrm{~b}$ \\
\hline Colonião & $67,9 \mathrm{ab}$ & $92,6 \mathrm{a}$ & $87,2 \mathrm{a}$ \\
K191 & $89,4 \mathrm{a}$ & $57,3 \mathrm{ab}$ & $46,5 \mathrm{ab}$ \\
K217 & $79,1 \mathrm{a}$ & $49,9 \mathrm{ab}$ & $41,1 \mathrm{ab}$ \\
KK10 & $57,7 \mathrm{ab}$ & $51,1 \mathrm{ab}$ & $44,0 \mathrm{ab}$ \\
KK33 & $37,7 \mathrm{~b}$ & $28,9 \mathrm{~b}$ & $19,1 \mathrm{~b}$ \\
KK8 & $81,9 \mathrm{a}$ & $42,7 \mathrm{~b}$ & $33,7 \mathrm{~b}$ \\
T46 & $49,3 \mathrm{ab}$ & $55,8 \mathrm{ab}$ & $52,8 \mathrm{ab}$ \\
T91 & 16,69 & 24,54 & 27,45 \\
\hline C.V. genótipo & 24,58 & & \\
C.V. doses de Al &
\end{tabular}

Médias seguidas de mesma letra, minúscula em cada coluna, não diferem pelo teste de Tukey $(\mathrm{P}>0,05)$

A análise de regressão polinomial mostrou que o incremento de alumínio na solução nutritiva promoveu decréscimos lineares no CRRS dos genótipos K217, KK10, KK33 e KK8, e variações quadráticas em Colonião e T46, com pontos de mínimo em 20,5 e 21,5 mg de $\mathrm{Al} \mathrm{L}^{-1}$ (Figura 5). Os genótipos K191 e T91 apresentaram ajustes a equações de segundo grau para o CRRS com o aumento da dose de alumínio. Os máximos CRRS para K191 e T91 ocorreram nas doses 15,8 e $14,2 \mathrm{mg}$ de $\mathrm{Al} \mathrm{L}^{-1}$, respectivamente.

Para o experimento II (Tabela 8) o teste de Tukey mostrou que, na média das doses, os genótipos T24 e T64 apresentaram maior CRRS que o T77. No geral, a média dos genótipos mostrou que o aumento na dose de alumínio na solução resultou em decréscimo no CRRS (Figura 6). 

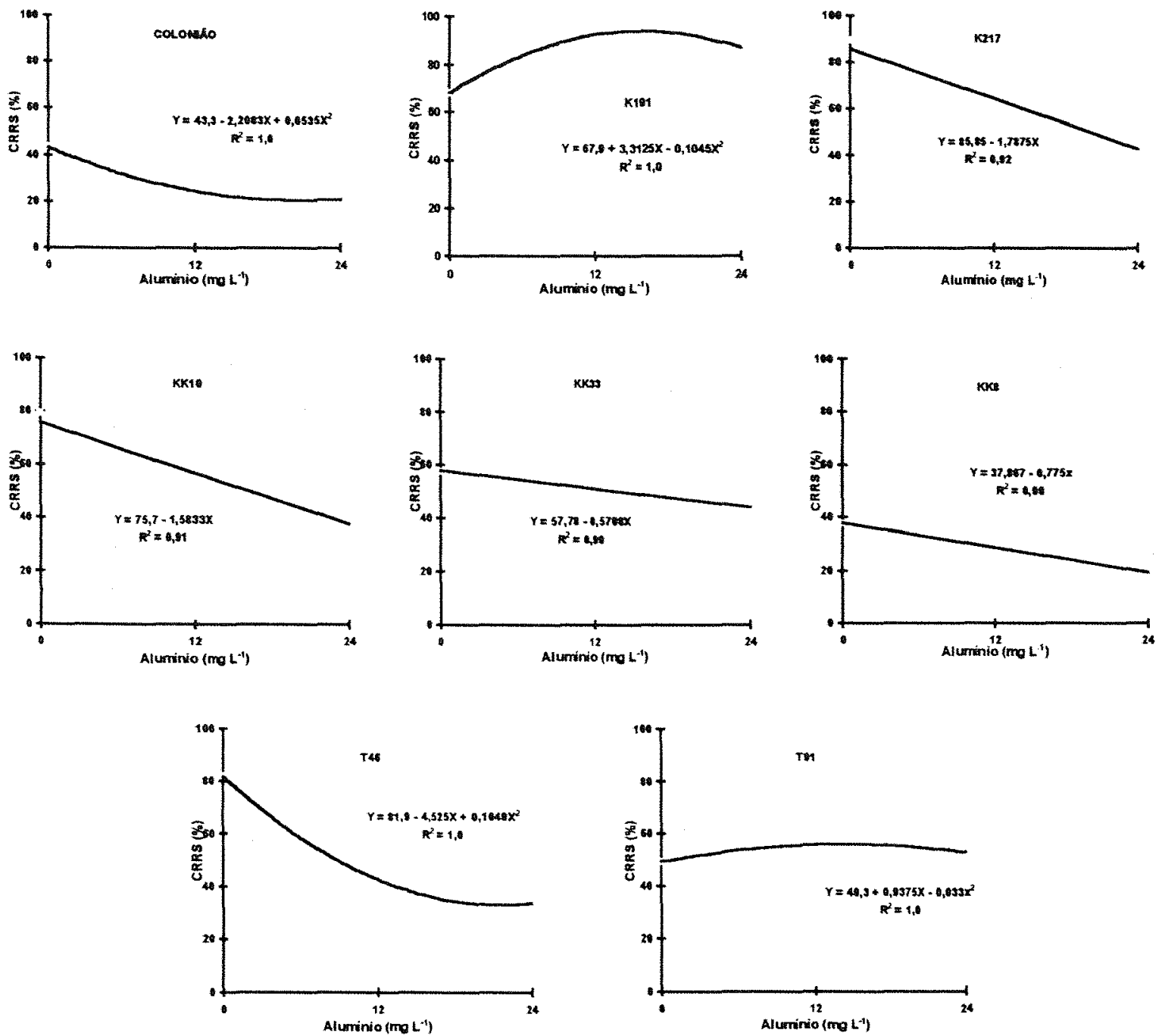

Figura 5 - Comprimento relativo da raiz seminal (CRRS) de genótipos de Panicum maximum submetidas a doses de alumínio no experimento I, em câmara-decrescimento. 
Tabela 8 - Comprimento relativo da raiz seminal (CRRS) de plantas de Panicum maximum submetidas a doses de alumínio no experimento II, em câmarade-crescimento.

\begin{tabular}{|c|c|c|c|c|}
\hline \multirow{3}{*}{ Genótipos } & \multicolumn{3}{|c|}{ CRRS $(\%)$} & \multirow{3}{*}{ Média } \\
\hline & \multicolumn{3}{|c|}{$\mathrm{Al}\left(\mathrm{mg} \mathrm{L} \mathrm{L}^{-1}\right)$} & \\
\hline & 0 & 12 & 24 & \\
\hline Colonião & 45,5 & 27,0 & 23,4 & $31,9 \mathrm{ab}$ \\
\hline Tobiatã & 42,5 & 26,4 & 20,3 & $29,7 \mathrm{ab}$ \\
\hline K193 & 47,5 & 27,4 & 21,2 & $32,0 \mathrm{ab}$ \\
\hline $\mathrm{T} 21$ & 38,5 & 42,9 & 28,3 & $36,5 \mathrm{ab}$ \\
\hline T24 & 51,8 & 32,5 & 27,0 & $37,1 \mathrm{a}$ \\
\hline T60 & 32,4 & 30,8 & 19,4 & $27,5 \mathrm{ab}$ \\
\hline T64 & 46,0 & 42,3 & 35,2 & $41,1 \mathrm{a}$ \\
\hline $\mathrm{T} 77$ & 23,3 & 17,3 & 11,2 & $17,3 \mathrm{~b}$ \\
\hline T97 & 28,1 & 22,1 & 16,2 & $22,1 \mathrm{ab}$ \\
\hline
\end{tabular}

Médias seguidas de mesma letra minúscula na coluna, não diferem pelo teste de Tukey $(\mathrm{P}>0,05)$

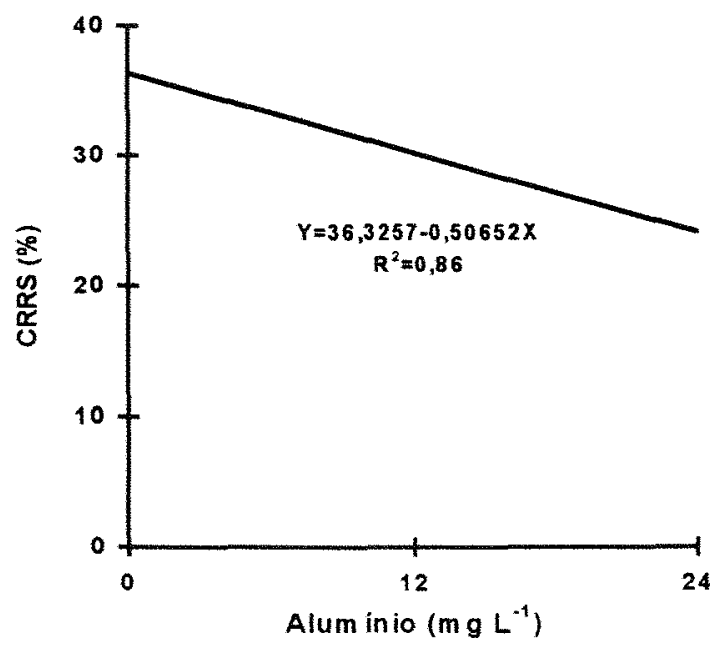

Figura 6- Comprimento relativo da raiz seminal (CRRS) das plantas de Panicum maximum submetidas a doses de alumínio no experimento II, em câmara-decrescimento. 
No experimento III (Tabela 9) o teste de Tukey revelou que, na média das doses, os genótipos Colonião e IZ-1 foram superiores em CRRS aos capins T84, Mombaça, Centenário e Centauro. Na média dos genótipos o aumento na dose de alumínio resultou em decréscimo no CRRS (Figura 7).

Tabela 9 - Comprimento relativo da raiz seminal (CRRS) de plantas de Panicum maximum submetidas a doses de alumínio no experimento III, em câmarade-crescimento.

\begin{tabular}{c|ccc|c}
\hline \multirow{3}{*}{ Genótipos } & \multicolumn{3}{|c|}{ CRRS (\%) } & \multirow{2}{*}{ Média } \\
\cline { 2 - 4 } & 0 & $\mathrm{Al}\left(\mathrm{mg} \mathrm{L}^{-1}\right)$ & 24 & \\
\hline Colonião & 42,8 & 27,0 & 21,0 & $30,3 \mathrm{a}$ \\
Centauro & 21,6 & 6,3 & 4,8 & $10,9 \mathrm{~b}$ \\
Centenário & 11,9 & 13,6 & 15,0 & $13,5 \mathrm{~b}$ \\
IZ-1 & 43,3 & 27,7 & 24,8 & $31,9 \mathrm{a}$ \\
K68 & 40,6 & 11,7 & 9,4 & $20,6 \mathrm{ab}$ \\
Mombaça & 23,7 & 18,5 & 11,6 & $17,9 \mathrm{ab}$ \\
T84 & 11,7 & 11,4 & 11,1 & $11,4 \mathrm{~b}$ \\
T110 & 29,3 & 15,6 & 11,6 & $18,8 \mathrm{ab}$ \\
\hline
\end{tabular}

Médias seguidas de mesma letra minúscula na coluna, não diferem pelo teste de Tukey $(P>0,05)$

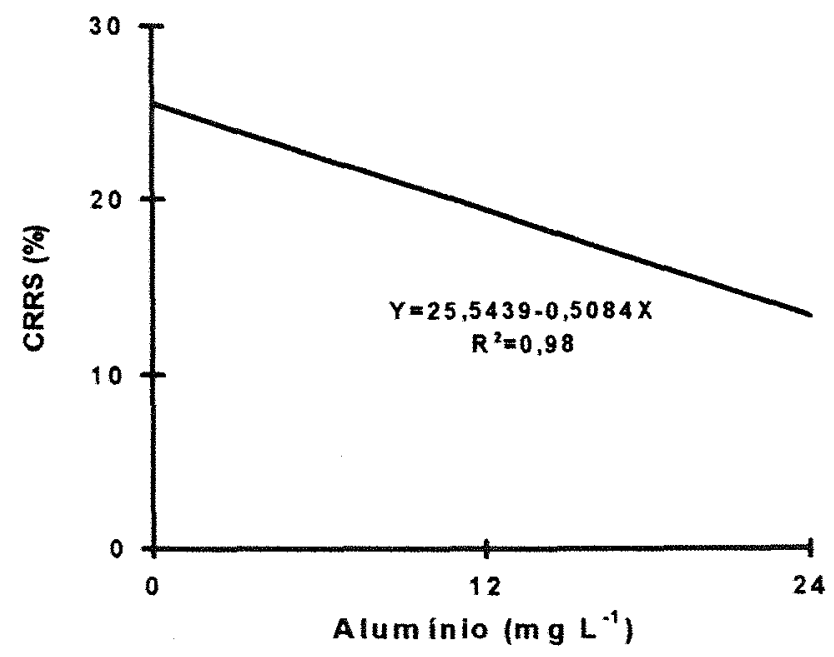

Figura 7 - Comprimento relativo da raiz seminal (CRRS) das plantas de Panicum maximum submetidas a doses de alumínio no experimento III, em câmara-decrescimento. 
No experimento IV (Tabela 10) o teste de Tukey não detectou diferenças significativas no CRRS entre os genótipos, assim como entre as doses de alumínio. Entretanto, apesar da não significância do fator, nota-se que na média dos genótipos, exceto T95 e Vencedor, há uma redução no valor absoluto de CRRS com o aumento da dose de alumínio no meio de crescimento.

Tabela 10 - Comprimento relativo da raiz seminal (CRRS) de plantas de Panicum maximum submetidas a doses de aluminio no experimento IV, em câmarade-crescimento.

\begin{tabular}{c|ccc|c}
\hline \multirow{3}{*}{ Genótipos } & \multicolumn{3}{|c|}{ CRRS (\%) } & \multirow{2}{*}{ Média } \\
\cline { 2 - 4 } & 0 & Al (mg L L $)$ & \\
\hline Colonião & 67,3 & 12 & 24 & $48,9 \mathrm{a}$ \\
K214 & 62,1 & 25,0 & 18,6 & $35,1 \mathrm{a}$ \\
K249 & 50,4 & 33,3 & 16,0 & $33,2 \mathrm{a}$ \\
T62 & 64,3 & 40,2 & 39,1 & $47,9 \mathrm{a}$ \\
T72 & 53,2 & 40,8 & 16,2 & $36,7 \mathrm{a}$ \\
T95 & 22,9 & 28,1 & 30,3 & $27,1 \mathrm{a}$ \\
Tanzânia-1 & 33,5 & 31,4 & 26,9 & $30,6 \mathrm{a}$ \\
Vencedor & 64,2 & 51,1 & 51,4 & $55,6 \mathrm{a}$ \\
\hline Média & $52,2 \mathrm{~A}$ & $36,6 \mathrm{~A}$ & $29,3 \mathrm{~A}$ & \\
\hline
\end{tabular}

Médias seguidas de mesma letra, maiúscula na linha e minúscula na coluna, não diferem pelo teste de Tukey $(\mathrm{P}>0,05)$

O parâmetro comprimento relativo da raiz seminal (CRRS) tem sido muito usado em estudos que envolvem a seleção de plantas, principalmente milho e trigo, para a tolerância ao alumínio (Horst et al., 1997; Parentoni et al., 1997; Torres et al., 1997).

Parentoni et al. (1997), trabalhando com linhagens de milho híbrido, utilizaram o comprimento relativo da raiz seminal (CRRS) como parâmetro na seleção de plantas com distintos graus de tolerância ao alumínio. Os autores afirmaram que este índice é um bom indicador do grau de tolerância ao alumínio. 
Por ser um parâmetro obtido da relação entre os comprimento final e o inicial da raiz, o comprimento relativo da raiz seminal (CRRS) permite identificar melhor a inibição do alongamento radicular induzida pelo alumínio.

\subsubsection{Inibição do alongamento radicular induzida pelo alumínio (I)}

Com base nos valores de comprimento relativo da raiz seminal (CRRS) foram avaliadas as variações na inibição do alongamento radicular entre os 30 genótipos de Panicum maximum cultivados em solução nutritiva com alumínio (Figuras 8 e 9).

O principal efeito do excesso do alumínio é a inibição do alongamento radicular, o qual pode ser utilizado como critério para definir graus de tolerância ao alumínio em um conjunto de genótipos.

A inibição do alongamento radicular entre os 30 genótipos de Panicum maximum cultivados com $12 \mathrm{mg}$ de $\mathrm{Al} \mathrm{L}^{-1}$ de solução nutritiva é ilustrada na Figura 8, onde se verifica que os cinco genótipos K191, T95, Centenário, T91 e T21 apresentaram estímulo no alongamento da raiz seminal, o que caracteriza a tolerância dessas plantas a essa dose do elemento. Por outro lado, os genótipos Centauro, K68, K214, T46 e T110 se mostraram os cinco mais sensíveis à adição de $12 \mathrm{mg}$ de $\mathrm{Al} \mathrm{L}^{-1}$ de solução nutritiva.

$\mathrm{Na}$ dose de $24 \mathrm{mg}$ de $\mathrm{Al} \mathrm{L}^{-1}$ (Figura 9) também se observa que os quatro genótipos T95, K191, Centenário e T91 mostraram estímulo do alongamento radicular, enquanto que os genótipos Centauro, K68, K214, T46, T110 tiveram o alongamento radicular acentuadamente inibido pelo alumínio. 


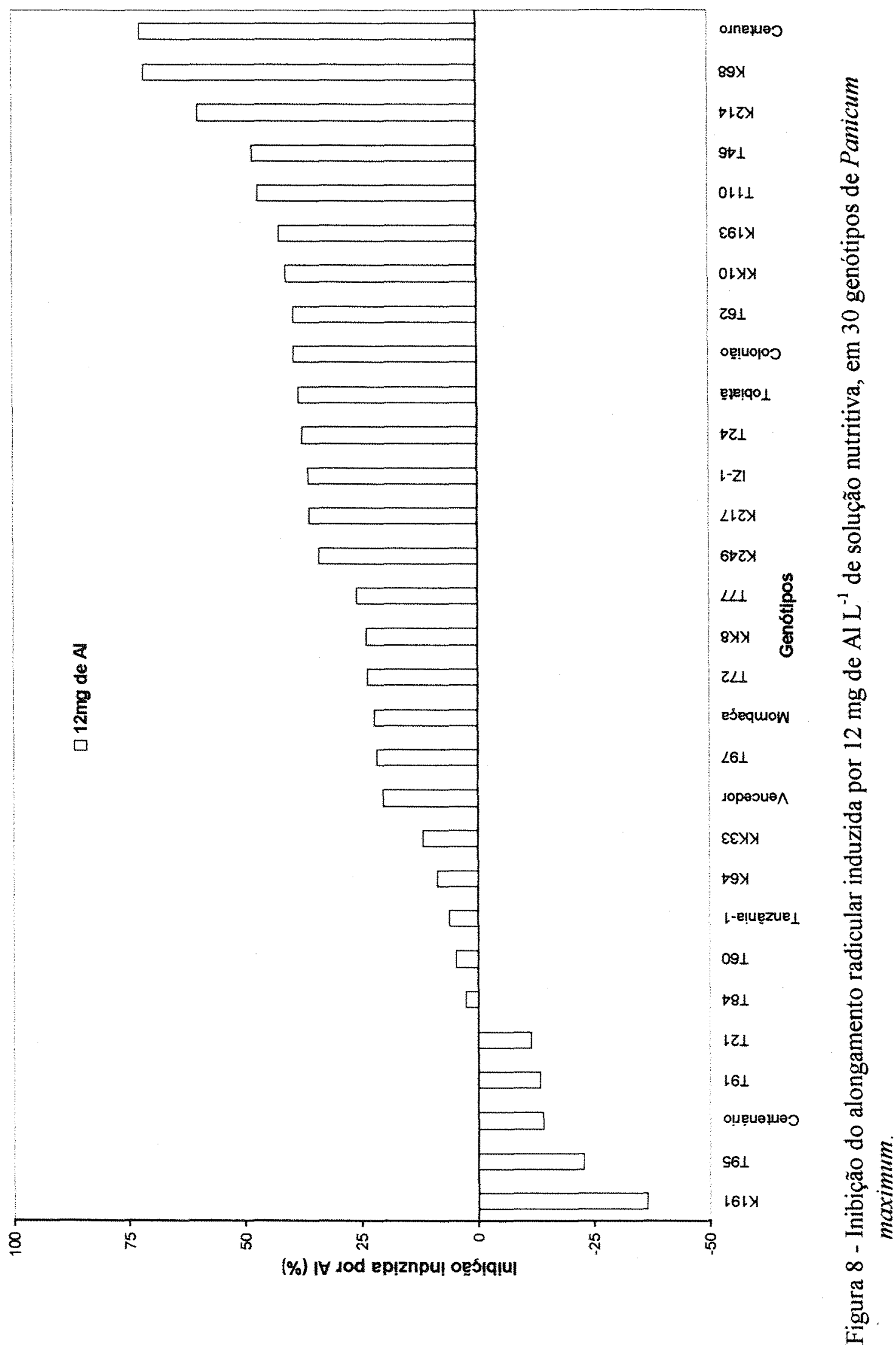




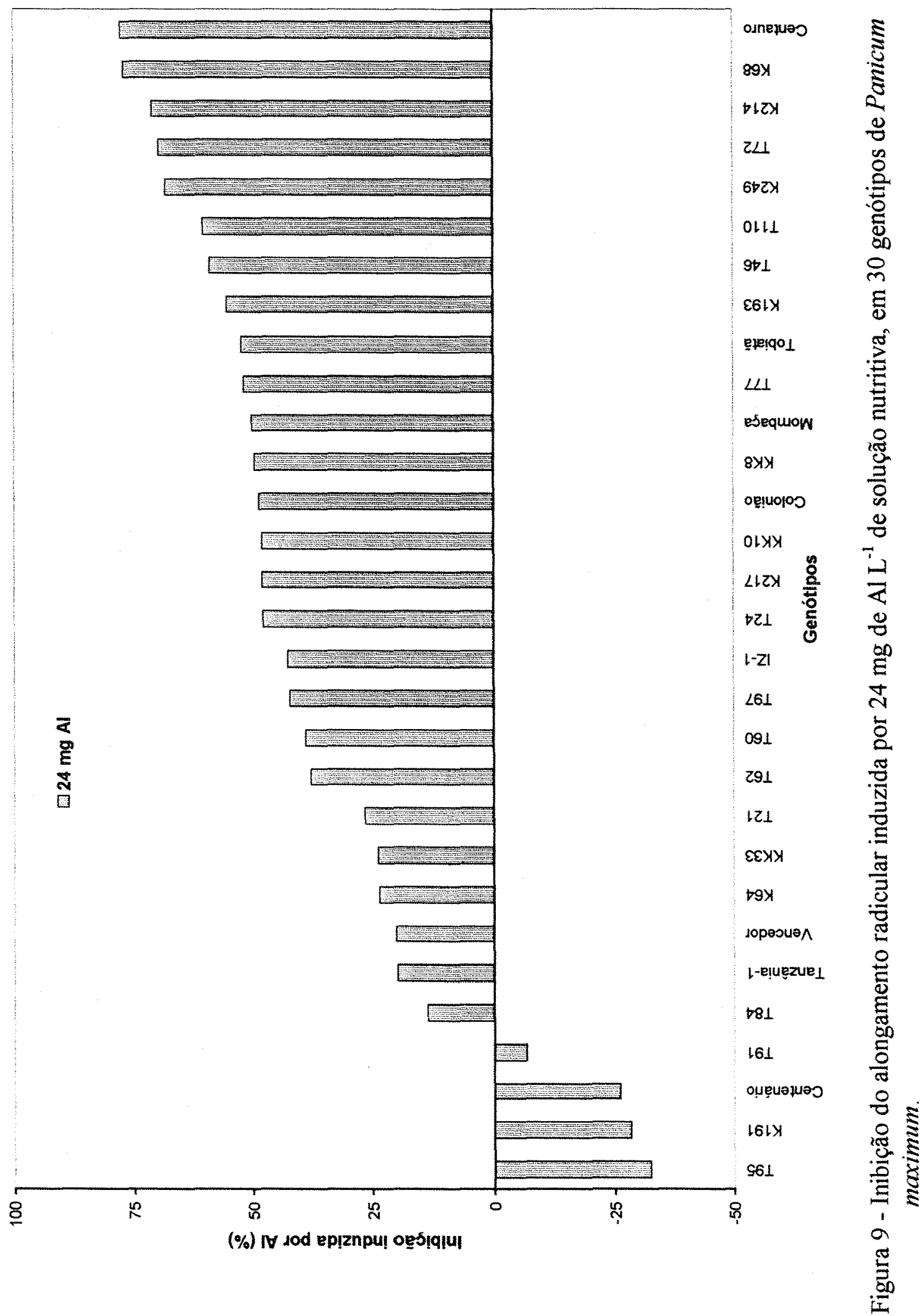


Tais resultados demonstram claramente a existência de diferenças no grau de tolerância ao alumínio entre os genótipos de Panicum maximum estudados, determinada pela inibição do alongamento da raiz seminal. Em ambas as doses estudadas, os genótipos Centauro, K68 e K214 foram os mais afetados pelo efeito inibidor do alumínio sobre o alongamento radicular. Em contrapartida, os genótipos K191, T91, T95 e Centenário destacaram-se pelo estímulo do crescimento de suas raízes seminais na presença de alumínio.

A inibição do alongamento radicular pode ser utilizada como critério para definir graus de tolerância ao alumínio em um conjunto de genótipos. Dessa forma, os capins avaliados foram classificados em três grupos: tolerante, intermediário e sensível, adotando-se para definições como sensível o genótipo com inibição do crescimento radicular maior que $40 \%$, como intermediário aquele com inibição entre 40 e $20 \%$ e tolerante quando a inibição foi menor que $20 \%$ (Tabela 11).

\subsection{4 Índice de tolerância ao alumínio (ITR-Al)}

Na Tabela 12 são apresentadas as médias do indice de tolerância relativa ao alumínio (ITR-Al) dos genótipos de Panicum maximum. O índice foi estimado a partir dos resultados de crescimento relativo da raiz seminal (CRS) compilados nos quatro experimentos.

Realizou-se a comparação entre genótipos com base no intervalo de confiança para as médias de ITR-Al com $95 \%$ de probabilidade, em uma distribuição " $\mathrm{t}$ ": $\mathrm{s}_{\bar{x}} \cdot \mathrm{t}{ }_{(0,05 ; \mathrm{n}-1)}$. Os genótipos que apresentaram valores de ITR-Al superiores ao intervalo de confiança foram classificados como tolerantes, enquanto aqueles com valores inferiores ao intervalo de confiança foram classificados como sensíveis. Genótipos com valores de ITR-Al entre os limites máximo e mínimo do intervalo de confiança foram classificados como de tolerância intermediária. 
Tabela 11 - Classificação dos genótipos de Panicum maximum quanto à tolerância a 12 e $24 \mathrm{mg}$ de $\mathrm{Al} \mathrm{L}^{-1}$ de solução nutritiva.

\begin{tabular}{|c|c|c|c|c|}
\hline \multirow{3}{*}{ Genótipo } & \multicolumn{4}{|c|}{ Alumínio $\left(\mathrm{mg} \mathrm{L}^{-1}\right)$} \\
\hline & \multicolumn{2}{|c|}{12} & \multicolumn{2}{|c|}{24} \\
\hline & Inibição (\%) & Classe & Inibição $(\%)$ & Classe \\
\hline Centauro & 72 & Sensível & 78 & Sensível \\
\hline K68 & 71 & Sensivel & 77 & Sensivel \\
\hline $\mathrm{K} 214$ & 60 & Sensivel & 71 & Sensivel \\
\hline K249 & 34 & Sensivel & 68 & Sensivel \\
\hline $\mathrm{T} 110$ & 47 & Sensivel & 60 & Sensivel \\
\hline $\mathrm{T} 46$ & 48 & Sensivel & 59 & Sensivel \\
\hline KK10 & 41 & Sensivel & 48 & Sensivel \\
\hline K193 & 42 & Sensivel & 55 & Sensivel \\
\hline $\mathrm{T} 72$ & 23 & Intermediário & 70 & Sensível \\
\hline Tobiatã & 38 & Intermediário & 52 & Sensível \\
\hline T77 & 26 & Intermediário & 52 & Sensível \\
\hline KK8 & 24 & Intermediário & 50 & Sensivel \\
\hline Mombaça & 22 & Intermediário & 50 & Sensivel \\
\hline Colonião & 39 & Intermediário & 49 & Sensível \\
\hline T24 & 37 & Intermediário & 48 & Sensível \\
\hline $\mathrm{K} 217$ & 36 & Intermediário & 48 & Sensível \\
\hline IZ-1 & 36 & Intermediário & 43 & Sensível \\
\hline Т97 & 21 & Intermediário & 42 & Sensível \\
\hline T62 & 39 & Intermediário & 38 & Intermediário \\
\hline $\mathrm{T} 60$ & 5 & Tolerante & 39 & Intermediário \\
\hline $\mathrm{T} 21$ & -11 & Tolerante & 26 & Intermediário \\
\hline KK33 & 12 & Tolerante & 24 & Intermediário \\
\hline K64 & 9 & Tolerante & 23 & Intermediário \\
\hline Vencedor & 20 & Tolerante & 20 & Tolerante \\
\hline Tanzânia-1 & 6 & Tolerante & 20 & Tolerante \\
\hline T84 & 3 & Tolerante & 14 & Tolerante \\
\hline T91 & -13 & Tolerante & -7 & Tolerante \\
\hline Centenário & -14 & Tolerante & -26 & Tolerante \\
\hline K191 & -36 & Tolerante & -28 & Tolerante \\
\hline T95 & -23 & Tolerante & -32 & Tolerante \\
\hline
\end{tabular}

* Sensivel (I $>40 \%)$, Intermediário $(40 \%>$ I $>20 \%)$ e Tolerante $(\mathrm{I}<20 \%)$. 
Tabela 12 - Índice de tolerância relativa ao alumínio (ITR-Al) de 30 genótipos de

\begin{tabular}{|c|c|c|c|c|}
\hline \multirow{3}{*}{ Genótipo } & \multicolumn{4}{|c|}{ ITR-AI } \\
\hline & \multicolumn{4}{|c|}{$A \mid\left(\mathrm{mg} \mathrm{L}^{-1}\right)$} \\
\hline & \multicolumn{2}{|c|}{12} & \multicolumn{2}{|c|}{24} \\
\hline K68 & 1,39 & Sensivel & 1,32 & Sensivel \\
\hline $\mathrm{K} 214$ & 2,16 & Sensivel & 1,05 & Sensível \\
\hline K249 & 1,39 & Sensivel & 1,32 & Sensível \\
\hline KK33 & 2,42 & Sensível & 1,38 & Sensível \\
\hline T46 & 1,76 & Sensivel & 1,41 & Sensivel \\
\hline T72 & 2,48 & Sensivel & 1,77 & Sensível \\
\hline Colonião & 2,25 & Sensível & 1,68 & Sensível \\
\hline$I Z-1$ & 2,30 & Sensível & 1,47 & Sensivel \\
\hline Centauro & 1,00 & Sensível & 1,00 & Sensível \\
\hline T77 & 2,67 & Intermediário & 1,17 & Sensivel \\
\hline Tobiatã & 2,67 & Intermediário & 1,17 & Sensível \\
\hline K193 & 2,48 & Sensível & 2,67 & Intermediário \\
\hline $\mathrm{T} 110$ & 2,25 & Sensível & 2,03 & Intermediário \\
\hline K217 & 2,69 & Intermediário & 2,24 & Intermediário \\
\hline KK 10 & 3,30 & Intermediário & 2,18 & Intermediário \\
\hline $\mathrm{T} 24$ & 2,67 & Intermediário & 2,37 & Intermediário \\
\hline T62 & 2,74 & Intermediário & 2,05 & Intermediário \\
\hline T97 & 3,25 & Intermediário & 2,13 & Intermediário \\
\hline Vencedor & 2,73 & Intermediário & 2,26 & Intermediário \\
\hline KK8 & 4,49 & Tolerante & 2,01 & Intermediário \\
\hline $\mathrm{T} 60$ & 4,30 & Tolerante & 2,37 & Intermediário \\
\hline Mombaça & 3,58 & Tolerante & 2,22 & Intermediário \\
\hline Tanzânia-1 & 3,73 & Tolerante & 2,26 & Intermediário \\
\hline K64 & 3,03 & Intermediário & 3,12 & Tolerante \\
\hline T21 & 3,64 & Tolerante & 2,77 & Tolerante \\
\hline T91 & 3,76 & Tolerante & 2,97 & Tolerante \\
\hline T84 & 4,13 & Tolerante & 3,56 & Tolerante \\
\hline Centenário & 5,00 & Tolerante & 5,00 & Tolerante \\
\hline K191 & 6,70 & Tolerante & 5,00 & Tolerante \\
\hline T95 & 7,25 & Tolerante & 7,15 & Tolerante \\
\hline
\end{tabular}

Intervalo de confiança para a média calculada com $95 \%$ de probabilidade $s \bar{x} \cdot t_{(0,05 ; 29)}$ para ITR$\mathrm{Al}_{12}=2,60$ a 3,52 e para ITR- $\mathrm{Al}_{24}=1,87$ a 2,74 
A média e o intervalo de confiança para a média $\mathrm{s}_{\bar{x}} \cdot \mathrm{t}_{(0,05 ; 29)}$ para 0 índice de tolerância ao alumínio na dose $12 \mathrm{mg}$ de $\mathrm{Al} \mathrm{L}^{-1}\left(\mathrm{ITR}-\mathrm{Al}_{12}\right)$ foram 3,06 e 2,60 a 3,52, respectivamente. Para a dose $24 \mathrm{mg}$ de $\mathrm{Al} \mathrm{L}^{-1}$ (ITR-Al 24 ) esses valores foram 2,31 e 1,87 a 2,74 .

Dessa forma, os genótipos sensíveis à fitotoxicidade do alumínio foram K68, K214, K249, KK33, T46, T72, Colonião, IZ-1, Centauro, T77 e Tobiatã. Moderada tolerância foi detectada para os capins K193, T110, K217, K64, KK10, T24, T62, T97, KK8, T60, Mombaça, Vencedor e Tanzânia-1, enquanto classificaram-se como tolerantes o K191, T95, T21, T84, T91 e Centenário.

Esses valores de ITR-Al evidenciam que a maior parte dos genótipos avaliados possui de média a baixa tolerância ao alumínio. Cabe destacar os genótipos T95 e K191 por apresentarem altos valores de ITR-Al, revelando alta tolerância ao alumínio e superando o cultivar Centenário, utilizado como referência para a estimativa. O resultado de ITR-Al estimado para o cultivar comercial Tobiatã discorda daquele relatado por Usberti Filho et al. (1986) que, com base no ITR-Al, classificaram tal genótipo moderadamente tolerante ao alumínio.

Os resultados de ITR-Al para o cultivar Vencedor (CPAC-3148) classificaram-no como de tolerância intermediária ao alumínio, enquanto o cultivar Colonião foi classificado como sensível. Esses resultados confirmam as observações de Hutton \& Sousa (1987), que constataram ser o cultivar Vencedor mais produtivo que o Colonião em oxissolos com pH 4,7 e com alta saturação em alumínio.A partir dos resultados de ITR-Al (Tabela 12) e de inibição do alongamento radicular (Tabela 11) verifica-se que dentre os 30 genótipos de Panicum maximum avaliados em câmara-de-crescimento quanto à fitotoxicidade do alumínio, os acessos K191, T95 e T91 apresentaram maior tolerância ao alumínio que os cultivares comerciais Colonião, IZ-1, Centauro, Tobiatã, Vencedor, Tanzânia-1 e Mombaça. Assim sendo, esses acessos representam 
potencial genético importante no melhoramento dessa espécie, uma vez que, em termos de produtividade de matéria seca já são considerados genótipos promissores para a pecuária brasileira (Jank, 1994).

\subsection{Experimento com genótipos de Panicum maximum com tolerância diferencial ao alumínio}

Neste experimento foram utilizados os genótipos K191, T21 e Centauro, que se mostraram, tolerante-tolerante, tolerante-intermediário e sensível-sensível às doses 12 e $24 \mathrm{mg}$ de $\mathrm{Al} \mathrm{L}^{-1}$, respectivamente, nos experimentos de seleção realizados previamente em câmara-de-crescimento.

\subsubsection{Perfilhamento}

A análise de variância para o perfilhamento para o número de perfilhos nos três genótipos de Panicum maximum cultivados em solução nutritiva detectou significância $(\mathrm{P}<0,01)$ para os fatores genótipos e doses de alumínio, bem como para a interação genótipos $\mathrm{x}$ doses de alumínio.

$\mathrm{O}$ desdobramento da interação genótipos $\mathrm{x}$ doses de alumínio, para número de perfilhos por vaso permitiu verificar que, com exceção da dose $36 \mathrm{mg}$ de $\mathrm{Al} \mathrm{L}^{-1}$, o genótipo T21 sempre apresentou maior número de perfilhos que os outros dois genótipos estudados (Figura 10). Por sua vez, o genótipo K191 teve maior número de perfilhos que o Centauro em todas as doses de alumínio na solução, exceto na dose $0 \mathrm{mg}$ de $\mathrm{Al} \mathrm{L}^{-1}$. $\mathrm{Na}$ maior dose de alumínio não se constatou diferença significativa $(\mathrm{P}>0,05)$ no perfilhamento entre os cultivares T21 e K191. Comparando-se a dose 0 com a dose $6 \mathrm{mg}$ de $\mathrm{Al} \mathrm{L}^{-1}$, o número de perfilhos no genótipo K191 foi reduzido em apenas 3\% enquanto que em T21 essa redução foi de $37 \%$. 


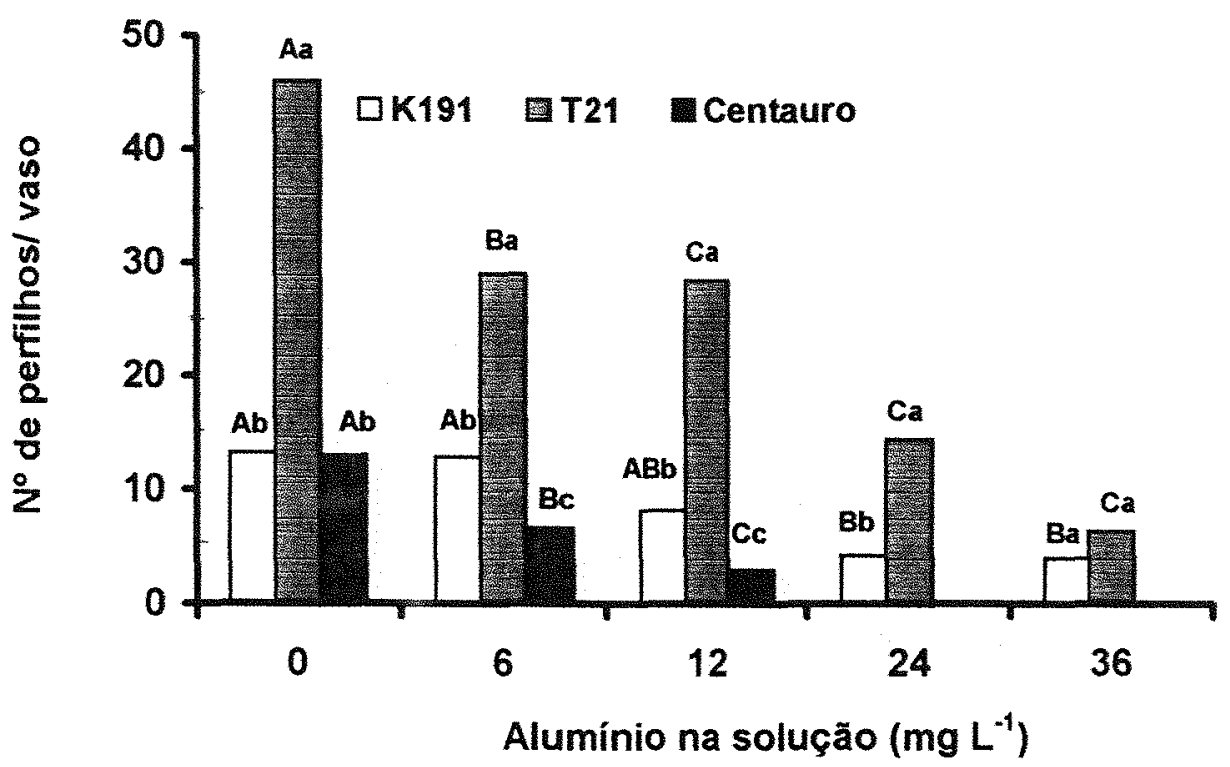

Figura 10 - Número médio de perfilhos em três genótipos de Panicum maximum em função das doses de alumínio na solução nutritiva. (Letras minúsculas comparam genótipos dentro de cada dose de alumínio e letras maiúsculas comparam doses de alumínio dentro de cada genótipo, pelo teste de Tukey $(\mathrm{P}<0,05))$

$\mathrm{Na}$ omissão de alumínio o perfilhamento das plantas do genótipo sensível, o cultivar Centauro, foi idêntico ao das plantas do genótipo tolerante, K191. Todavia, as plantas de Centauro foram severamente afetadas pela adição de aluminio na solução nutritiva, visto que o perfilhamento foi reduzido em $49,5 \%$ e $77 \%$ nas doses 6 e $12 \mathrm{mg}$ de $\mathrm{Al} \mathrm{L}^{-1}$, respectivamente, em relação à dose $0 \mathrm{mg}$ de Al $\mathrm{L}^{-1}$. As plantas de Centauro cultivadas nas doses 24 e $36 \mathrm{mg}$ de $\mathrm{Al} \mathrm{L}^{-1}$ morreram após quinze dias do transplante para a solução nutritiva, em decorrência de sua sensibilidade ao alumínio.

A redução no perfilhamento de gramíneas forrageiras em decorrência do excesso de alumínio é descrita na literatura. Fernandes et al. (1984) verificaram que a adição de $6 \mathrm{mg}$ de $\mathrm{Al} \mathrm{L} \mathrm{L}^{-1}$ de solução nutritiva reduziu igualmente, aproximadamente $50 \%$, o perfilhamento das forrageiras Brachiaria decumbens, considerada tolerante, e Cenchrus ciliaris, considerada sensível ao alumínio. 


\subsubsection{Volume do sistema radicular}

Quanto ao volume do sistema radicular dos três genótipos de Panicum maximum, em função das doses de alumínio, o teste $F$ revelou significância $(\mathrm{P}<0,05)$ para os fatores genótipos e doses de alumínio, como também para a interação genótipos $\mathrm{x}$ doses de alumínio.

Na Figura 11 observa-se que para as doses de alumínio empregadas não foram detectadas diferenças significativas $(P>0,05)$ entre os genótipos K191 e T21.

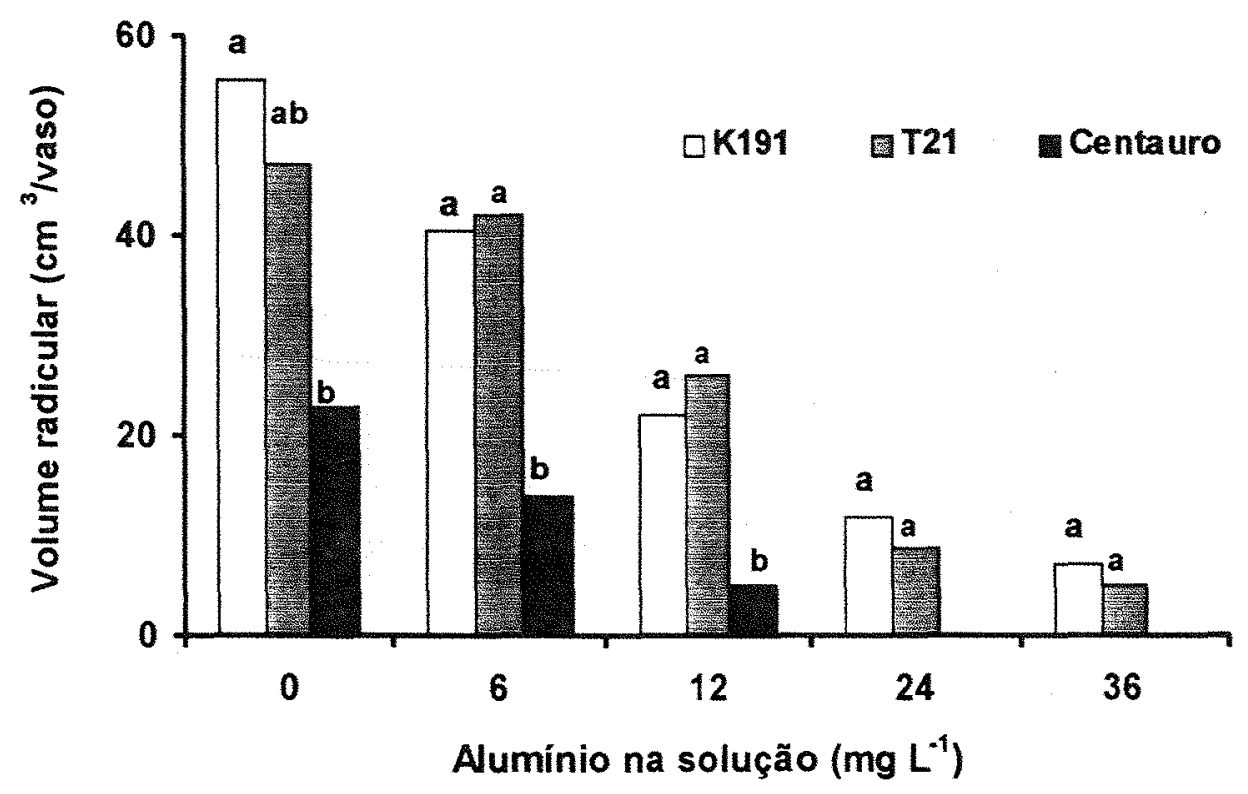

Figura 11- Volume do sistema radicular em três genótipos de Panicum maximum em função das doses de alumínio na solução nutritiva. (Letras comparam genótipos dentro de cada dose de alumínio pelo teste de Tukey a $5 \%$ ).

$\mathrm{Na}$ mesma figura, verifica-se que nas doses de 6 e $12 \mathrm{mg}$ de $\mathrm{Al} \mathrm{L}^{-1}$ os genótipos K191 e T21 apresentaram maior volume do sistema radicular que 0 capim-centauro. $\mathrm{Na}$ dose 0 somente o K191 diferiu do Centauro quanto ao

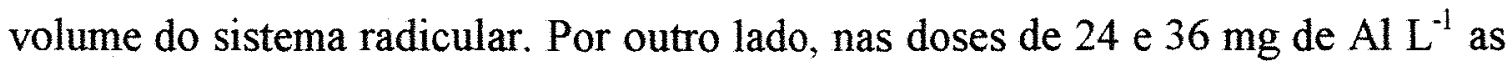


plantas de Centauro morreram e não foi possível obter o volume do sistema radicular por ocasião do corte das plantas.

O ajuste de modelos matemáticos, fornecidos pela análise de regressão, representou a redução do volume radicular dos genótipos de forma quadrática, com pontos de mínimo em 31,40 e $27 \mathrm{mg}$ de $\mathrm{Al} \mathrm{L}^{-1}$, respectivamente para $\mathrm{K} 191$, T21 e Centauro (Figura 12).

Observa-se que o volume de raízes do Centauro foi seriamente afetado com o incremento de alumínio, exibindo reduções de $52 \%$ e $78 \%$ nas doses 6 e $12 \mathrm{mg}$ de $\mathrm{Al} \mathrm{L} \mathrm{L}^{-1}$, respectivamente. Este comportamento já era esperado uma vez que estas plantas mostraram drástica inibição do crescimento das raízes em presença de alumínio no experimento de seleção dos genótipos (Figuras 8 e 9).

A redução do volume radicular foi menor nas plantas resistentes K191 e T21 do que em Centauro, planta sensível ao alumínio. Entre as doses 0 e $6 \mathrm{mg}$ de $\mathrm{Al} \mathrm{L}^{-1}$ o genótipo $\mathrm{T} 21$ apresentou decréscimo no volume radicular de $11 \%$, enquanto que no genótipo K191 a redução foi de $27 \%$. De 0 para $12 \mathrm{mg}$ de $\mathrm{Al} \mathrm{L}^{-1}$ a redução no volume radicular foi acentuada em 45 e 60\% para T21 e K191, respectivamente.

Fernandes et al. (1984) verificaram que a adição de $6 \mathrm{mg}$ de $\mathrm{Al} \mathrm{L}^{-1}$ na solução nutritiva promoveu redução de $35 \%$ no volume radicular da Brachiaria decumbens, espécie tolerante ao alumínio, enquanto que em Cenchrus ciliaris, espécie sensível, a redução foi de $54 \%$. No presente estudo verificou-se que na dose de $6 \mathrm{mg}$ de $\mathrm{Al} \mathrm{L}^{-1}$ o genótipo de Panicum maximum tolerante, K191, apresentou menor redução do volume radicular comparado ao resultado de Fernandes et al. (1984) para a Brachiaria decumbens. 


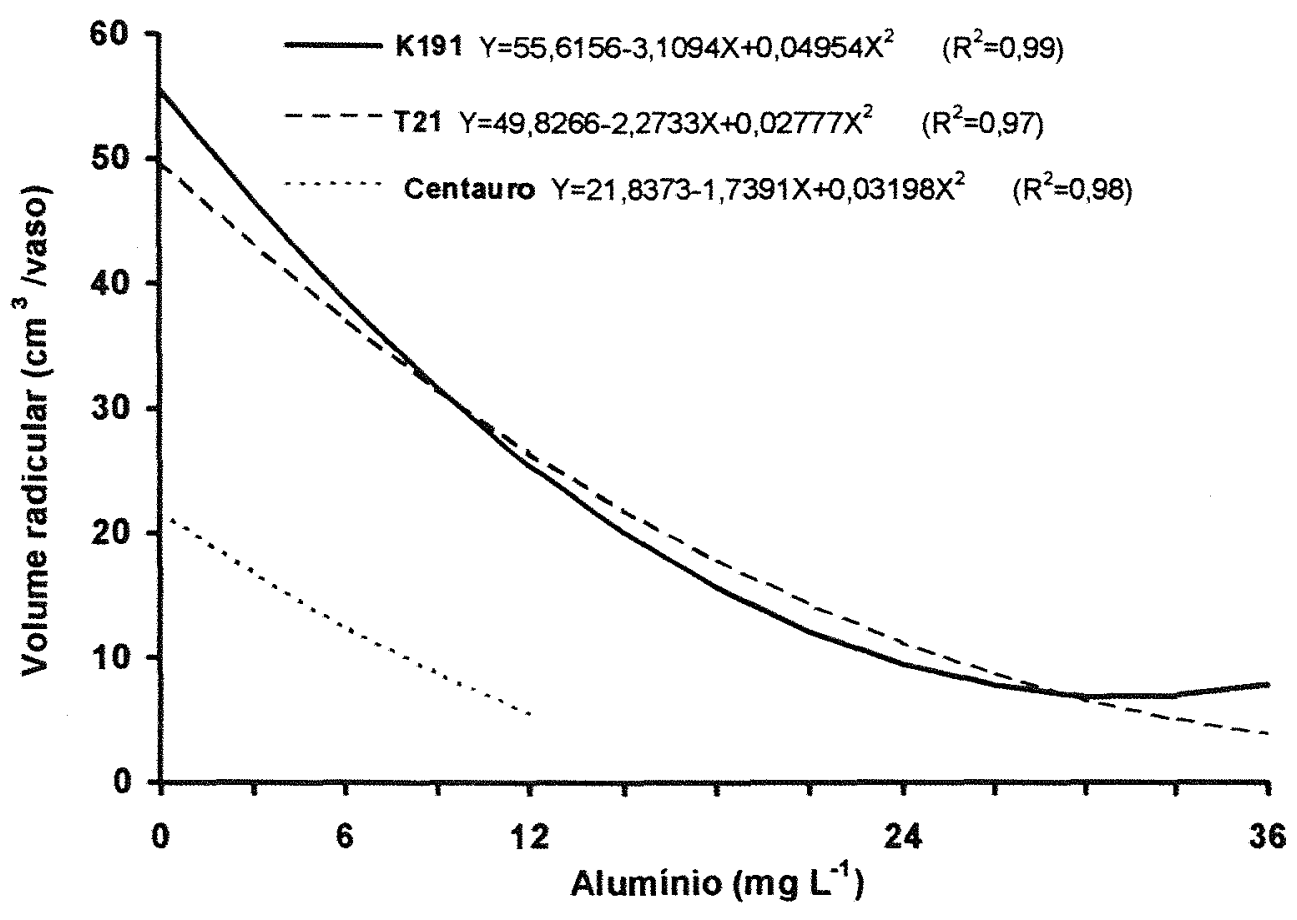

Figura 12 - Volume radicular em três genótipos de Panicum maximum em função das doses de alumínio na solução nutritiva.

\subsubsection{Atividade da redutase do nitrato nas folhas}

Para a atividade da redutase de nitrato determinada nas folhas dos três capins estudados, a análise de variância mostrou que a interação entre genótipos e doses de alumínio foi significativa $(\mathrm{P}<0,05)$.

A única diferença significativa observada entre genótipos ocorreu na dose $12 \mathrm{mg} \mathrm{L}^{-1}$, na qual as atividades da redutase de nitrato do K191 e do T21 superaram a do Centauro (Figura 13). 


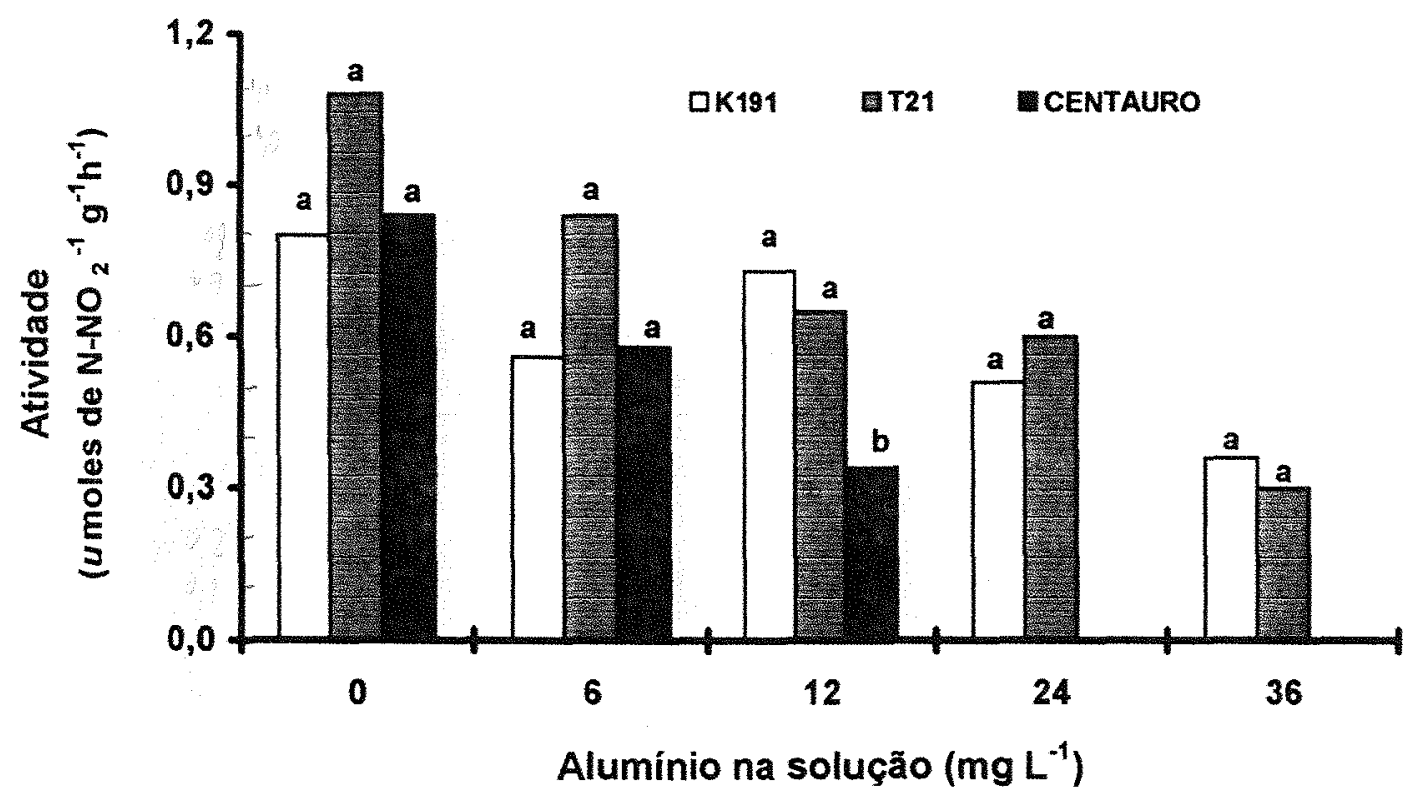

Figura 13 - Atividade da redutase do nitrato nas folhas de três genótipos de Panicum maximum em função das doses de alumínio na solução nutritiva. (Letras comparam genótipos dentro de cada dose de alumínio pelo teste de Tukey a 5\%)

A existência de diferenças no padrão de atividade da redutase do nitrato associada à tolerância ao excesso de alumínio em gramíneas é descrita na literatura. Foy \& Fleming (1982) relataram que, na presença ou ausência de alumínio na solução nutritiva, o genótipo de trigo UC 44-11, tolerante ao excesso desse ion, apresentou atividade da redutase do nitrato superior ao genótipo sensível, Anza. Cambraia et al. (1989) também verificaram que, tanto na omissão quanto na dose de $5 \mathrm{mg}$ de $\mathrm{Al} \mathrm{L}^{-1}$ de solução nutritiva, houve maior atividade da enzima no cultivar de sorgo tolerante do que no sensivel ao alumínio.

A análise de regressão ajustou modelos lineares que descrevem adequadamente a redução na atividade desta enzima em função do incremento de alumínio na solução nutritiva (Figura 14). O efeito inibitório do alumínio na atividade da redutase do nitrato também foi determinada em sorgo (Cambraia et al., 1989), trigo (Foy \& Fleming, 1982) e milho (Santoro et al., 1984). Para aveia, 
Floss (1992) não encontrou efeito significativo das doses de alumínio na atividade da enzima, porém, relatou que o genótipo sensível mostrou tendência de diminuição nessa atividade com o aumento da concentração de alumínio na solução.

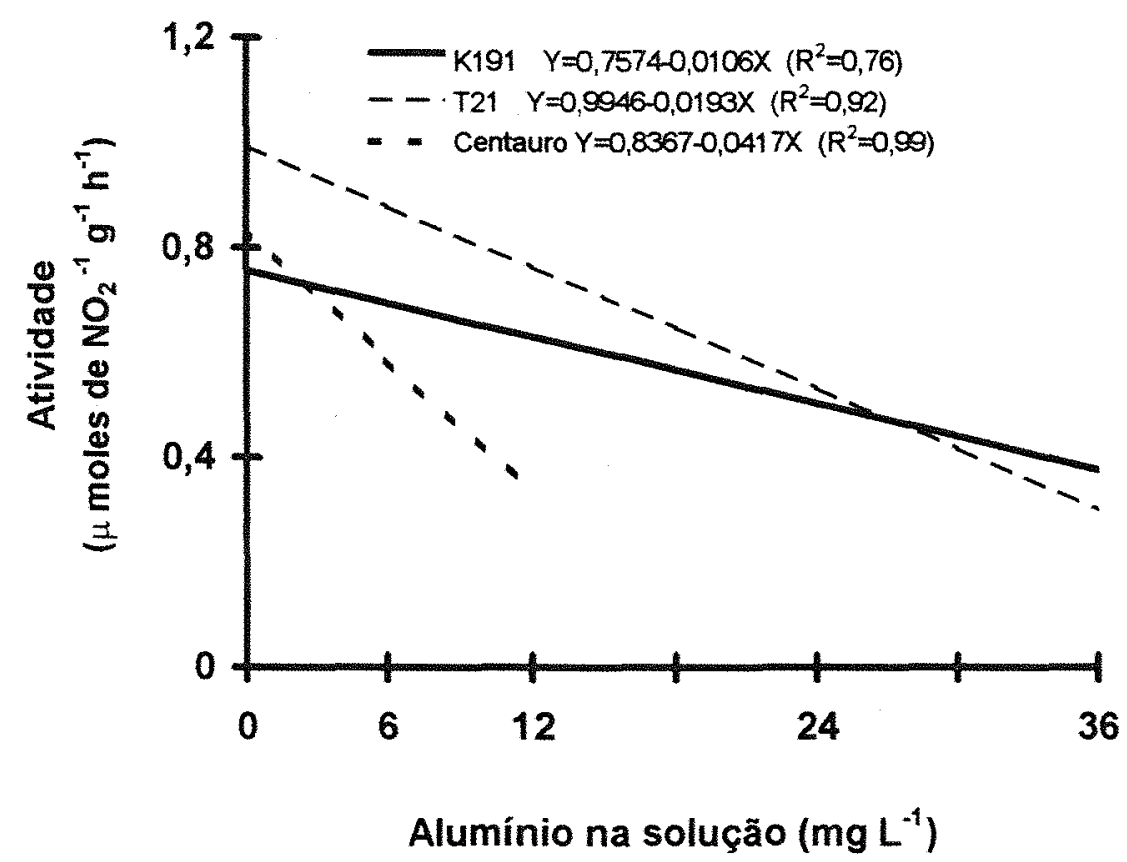

Figura 14 - Atividade da redutase do nitrato nas folhas de três genótipos de Panicum maximum em função das doses de aluminio na solução nutritiva.

\subsubsection{Atividade da fosfatase ácida nas folhas}

A análise de variância dos resultados relativos à atividade da fosfatase determinada nas folhas dos capins revelou que tanto a interação genótipos $\mathrm{x}$ doses de alumínio como o fator genótipos não foram significativos ( $P>0,05)$. $O$ teste $F$ detectou apenas o efeito significativo $(\mathrm{P}<0,05)$ para as doses de alumínio.

Pela Figura 15 pode-se notar que a atividade dessa enzima nas folhas dos três genótipos em função da adição de alumínio na solução nutritiva foi representada por uma equação de primeiro grau, de forma que a atividade dessa 
enzima teve incrementos com o aumento das doses de alumínio. $\mathrm{O}$ aumento da atividade da fosfatase ácida em função do incremento de alumínio na solução nutritiva foi descrita por Zaini \& Mercado (1985) que, utilizando plantas de arroz, determinaram aumento da atividade da enzima quando a concentração de alumínio na solução foi elevada de 3 para $30 \mathrm{mg} \mathrm{L}^{-1}$. Os autores explicaram que a atividade da enzima é alta quando o estado nutricional em fósforo é baixo, como neste caso em decorrência da deficiência de fósforo induzida pelo alumínio.

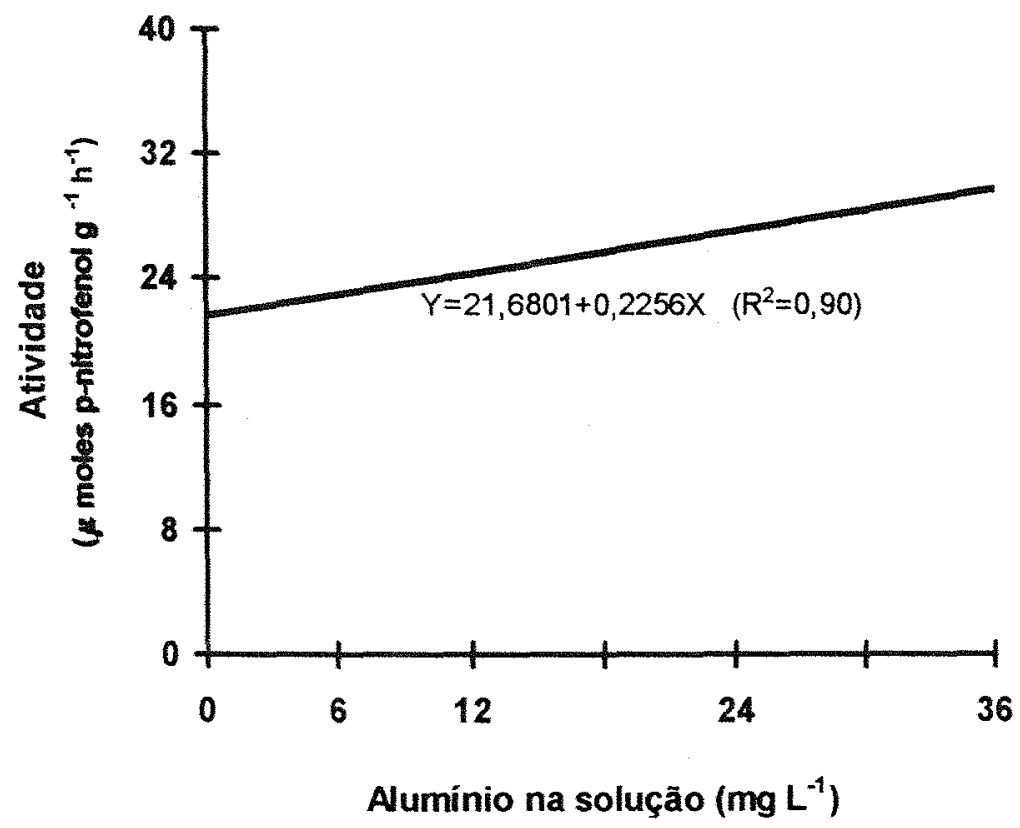

Figura 15 - Atividade da fosfatase ácida nas folhas de três genótipos de Panicum moximum em função das doses de alumínio na solução nutritiva.

\subsubsection{Rendimento de matéria seca}

\subsubsection{Raízes}

Quanto à produção de matéria seca de raizes dos genótipos de Panicum maximum, a análise de variância evidenciou significância $(\mathrm{P}<0,01)$ no teste $\mathrm{F}$ para a interação genótipos $\mathrm{x}$ doses de alumínio. 
A comparação entre as médias dessa produção para os genótipos dentro das doses de alumínio mostrou que o genótipo tolerante K191 não diferiu significativamente do genótipo intermediário T21, em qualquer das doses de alumínio empregadas (Figura 16).

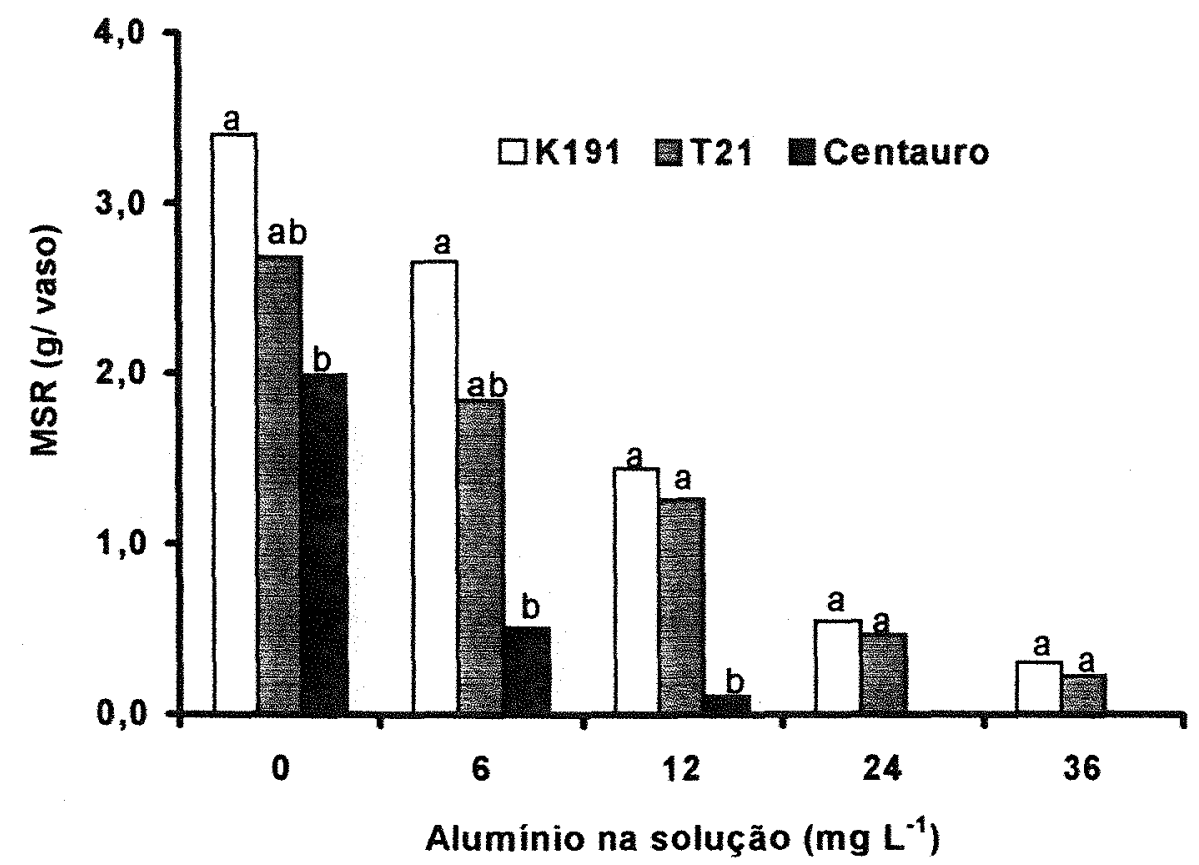

Figura 16 - Rendimento de matéria seca radicular (MSR) em três genótipos de Panicum maximum em função das doses de alumínio na solução nutritiva. (Letras comparam genótipos dentro de cada dose de alumínio pelo teste de Tukey a 5\%).

Cabe ressaltar que no estudo de seleção das plantas o genótipo K191 apresentou menor inibição do crescimento radicular que o genótipo T21 (Figuras 8 e 9), e que isto não se refletiu no rendimento de matéria seca das raizes das plantas cortadas aos 30 dias do transplante para os vasos.

$O$ incremento de alumínio na solução nutritiva resultou em redução sensível na produção de matéria seca de raizes em todos os genótipos, dentro dos limites de doses de alumínio estudadas (Figura 17). Essa limitação foi mais severa no genótipo Centauro, com reduções de 50 e $90 \%$ quando se compara a presença 
de 6 ou $12 \mathrm{mg}$ de $\mathrm{Al} \mathrm{L}^{-1}$, respectivamente, com a ausência desse elemento na solução. Esse comportamento do Centauro caracteriza sua extrema sensibilidade ao aluminio, o que justifica a morte das plantas nas doses mais elevadas desse íon na solução.

Para a limitação da produção de material seco de raizes a análise de regressão ajustou modelos quadráticos, com mínimos em $12 ; 33$ e $34 \mathrm{mg}$ de $\mathrm{Al} \mathrm{L}^{-1}$ para os genótipos Centauro, K191 e T21, respectivamente.

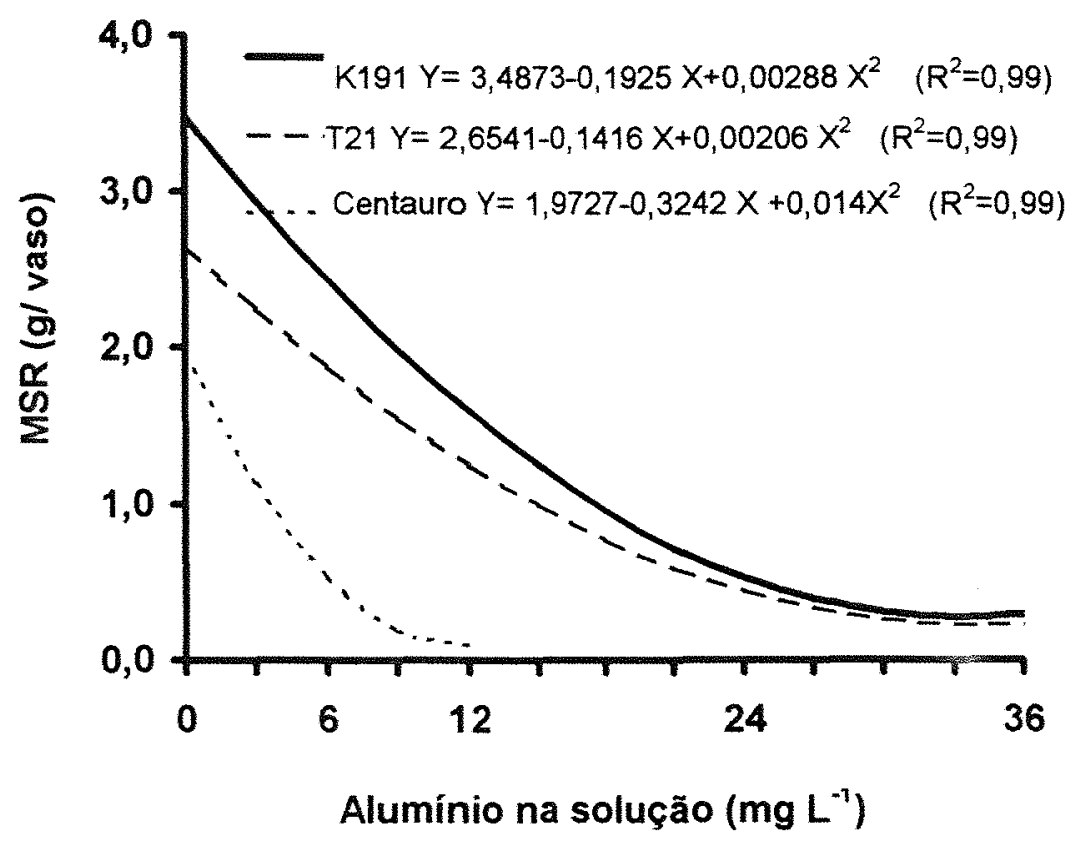

Figura 17 - Rendimento de matéria seca radicular (MSR) em três genótipos de Panicum maximum, em função das doses de alumínio na solução nutritiva.

\subsubsection{Parte aérea}

A análise de variância dos resultados de produção de matéria seca da parte aérea revelou que a interação genótipos $\mathrm{x}$ doses de alumínio foi significativa $(\mathrm{P}<0,01)$.

Através da Figura 18 verifica-se que novamente os genótipos K191 e T21 não mostraram diferenças na produção da matéria seca da parte aérea em 
quaisquer das doses estudadas. Na omissão de alumínio o cultivar Centauro, genótipo sensivel, apresentou menor produção de matéria seca da parte aérea comparado aos demais genótipos.

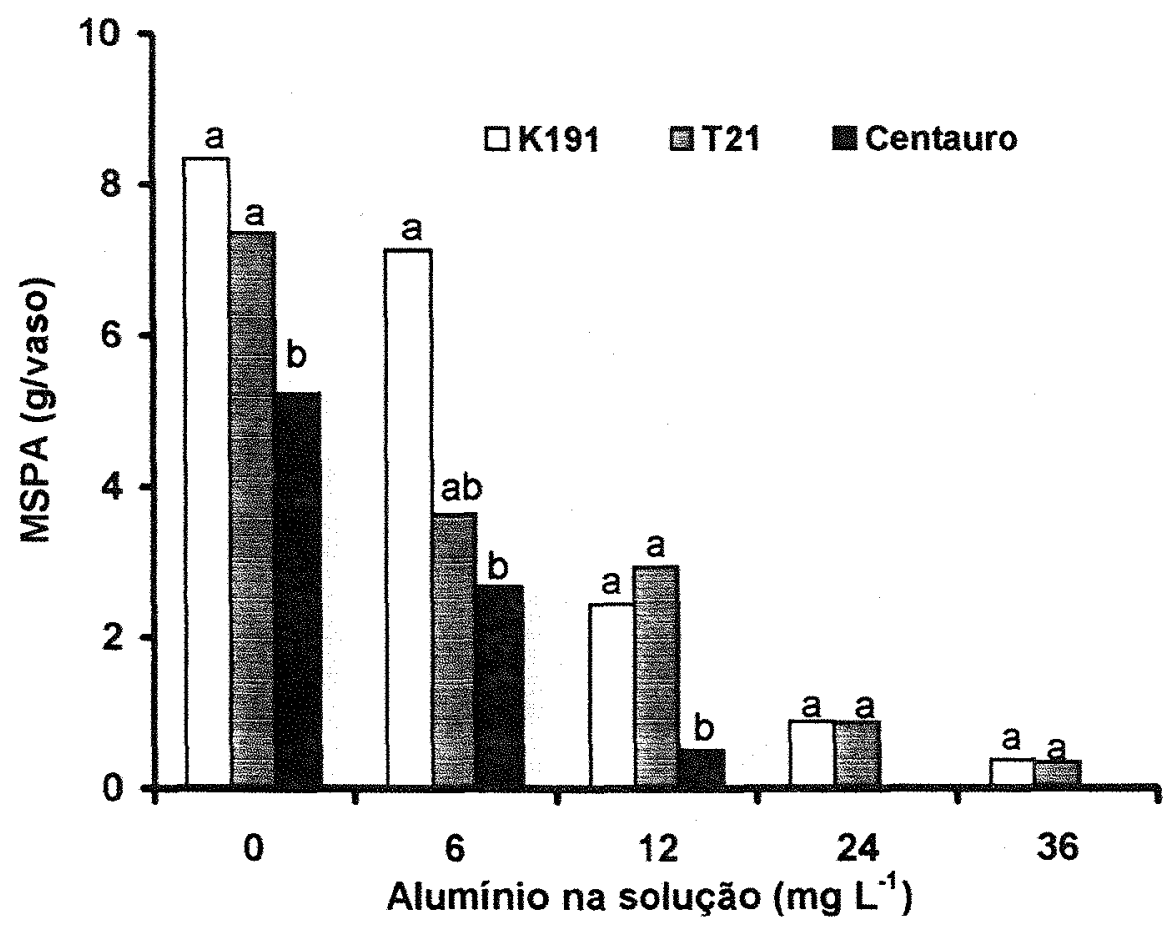

Figura 18 - Rendimento de matéria seca da parte aérea em três genótipos de Panicum maximum em função das doses de alumínio na solução nutritiva. (Letras comparam genótipos dentro de cada dose de alumínio pelo teste de Tukey a 5\%).

Esse comportamento é semelhante ao exibido na produção de matéria seca das raízes. Esses resultados corroboram os resultados de Floss (1992), que comparando genótipos de aveia com tolerância diferencial ao alumínio, verificou menor produção de matéria seca da parte aérea no genótipo sensível, comparado ao genótipo tolerante.

Todos os genótipos apresentaram redução no rendimento da matéria seca da parte aérea com a adição de alumínio na solução nutritiva (Figura 19). 


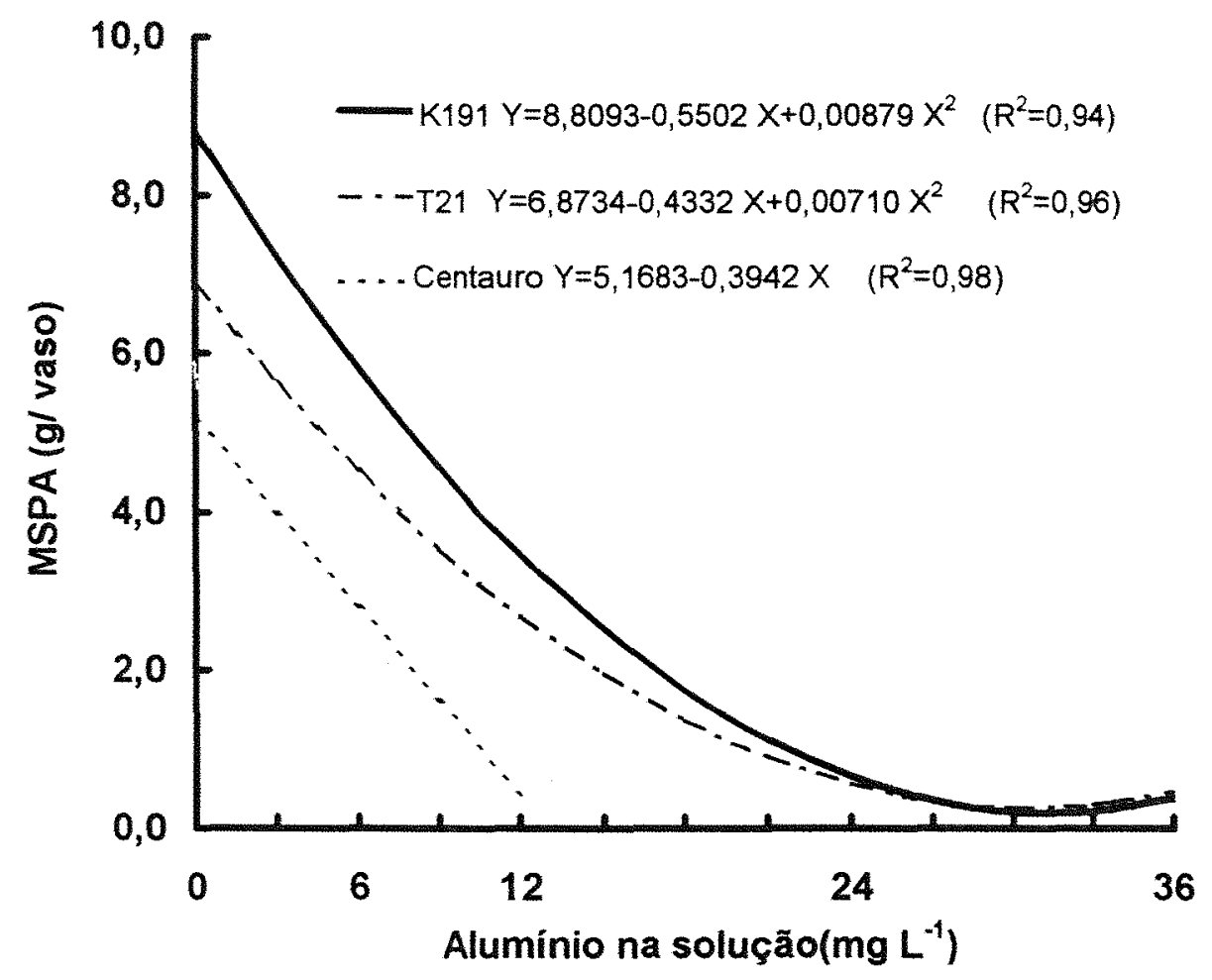

Figura 19 - Rendimento de matéria seca da parte aérea em três genótipos de Panicum maximum em função das doses de alumínio na solução nutritiva.

Os modelos quadráticos obtidos através da análise de regressão representaram a redução nas produções de matéria seca da parte aérea (MSPA) dos genótipos tolerante e intermediário, enquanto que o decréscimo do rendimento da MSPA do cultivar Centauro foi linear. As produções mínimas para K191 e T21 ocorreram, respectivamente, nas doses 31 e $30 \mathrm{mg}$ de $\mathrm{Al} \mathrm{L} \mathrm{L}^{-1}$. Inúmeros trabalhos de pesquisa também relataram declínio no rendimento da matéria seca da parte aérea do vegetal com o aumento da dose de alumínio na solução (Foy, 1988; Foy et al., 1978; Helyar, 1978 e Wheeler et al., 1992). Andrew et al. (1973) referiram que, para as leguminosas forrageiras Medicago scutellata, Medicago truncatula, Medicago sativa e Neonotonia wightii, sensíveis 
ao alumínio, a adição de alumínio na solução nutritiva promoveu decréscimo exponencial na produção da MSPA.

\subsubsection{Relação entre produções de matéria seca de raízes e da parte aérea (MSR/MSPA)}

A análise de variância para a relação entre as produções de matéria seca de raízes e da parte aérea (MSR/MSPA) mostrou que a interação entre genótipos e doses de alumínio foi significativa $(\mathrm{P}<0,05)$.

Comparando-se as médias para essa relação nos genótipos dentro de cada dose de alumínio (Figura 20) observa-se que na presença de 6 e $12 \mathrm{mg}$ de $\mathrm{Al} \mathrm{L}^{-1}$ a relação MSR/MSPA dos genótipos K191 e T21 supera aquela do Centauro, mas não se constatam diferenças significativas $(P>0,05)$ entre os primeiros.

$\mathrm{Na}$ Figura 21 são apresentados os ajustes resultantes da análise de regressão para a relação MSR/MSPA nos três genótipos de Panicum maximum, em função das doses de alumínio na solução. Verifica-se que os genótipos tolerante e intermediário responderam diferentemente do sensível. Para os capins K191 e T21 a relação MSR/MSPA se elevou com a adição de alumínio no meio de crescimento, enquanto que para o genótipo Centauro esses valores foram menores e decrescentes com o incremento de alumínio na solução. Considerando as afirmativas de Foy et al. (1967) e de Moore et al. (1976) de que o crescimento radicular é excelente indicador do grau de tolerância da planta à toxicidade do alumínio, mais uma vez constata-se a tolerância de K191 e T21 e a sensibilidade do Centauro ao alumínio no substrato. Nota-se que a relação MSR/MSPA tem maior coeficiente angular em K191 que em T21, evidenciando que essa relação cresce mais no genótipo tolerante que no intermediário. 


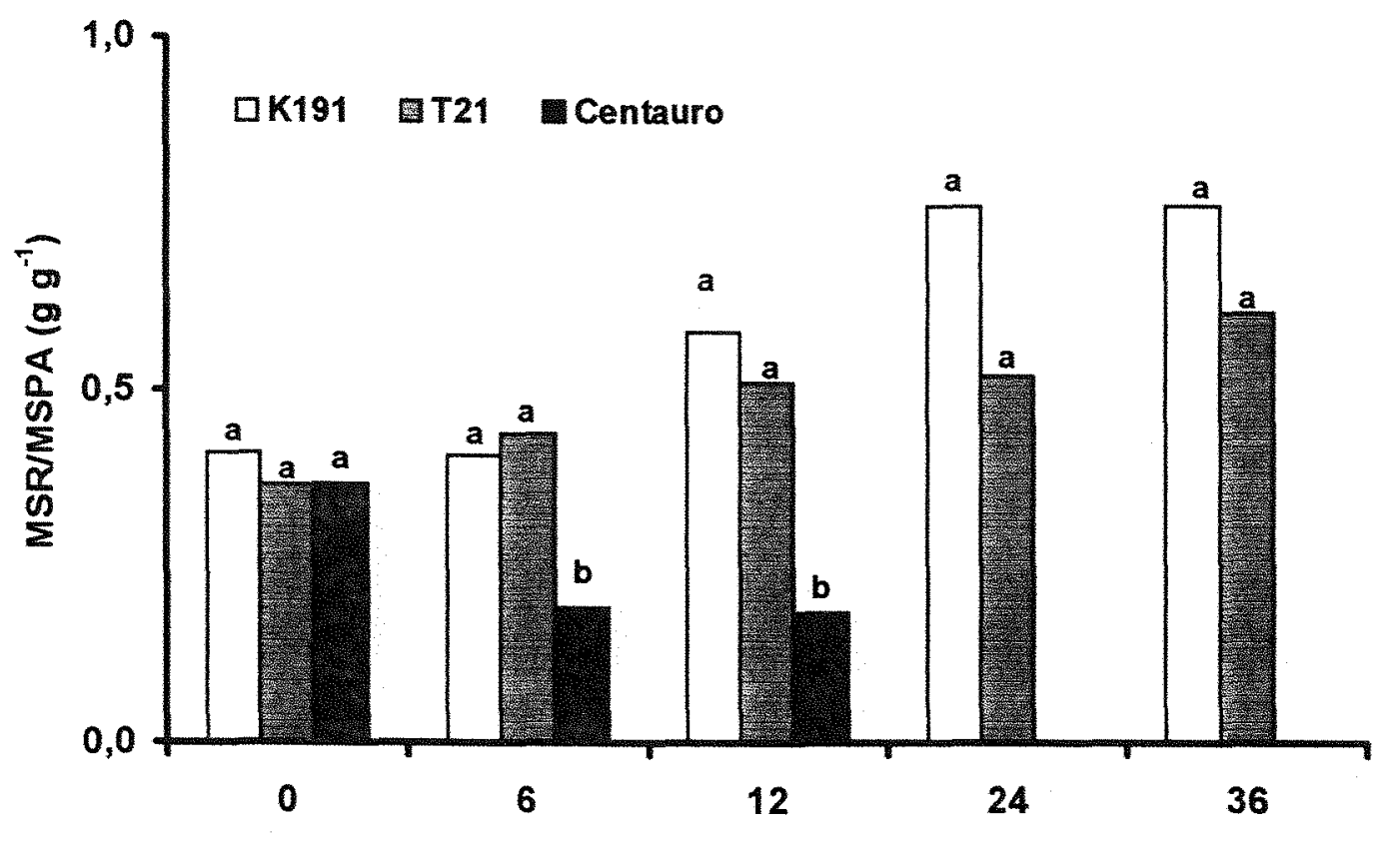

Aluminio na solução $\left(\mathrm{mg} \mathrm{L}^{-1}\right)$

Figura 20- Relação entre as produções de matéria seca de raízes e de parte aérea (MSR/MSPA) em três genótipos de Panicum maximum em função das doses de alumínio na solução nutritiva. (Letras comparam genótipos dentro de cada dose de alumínio pelo teste de Tukey a $5 \%$ ).

O alumínio afetou de forma mais acentuada a produção de matéria seca das raizes do que a da parte aérea no genótipo sensível, o Centauro, ocorrendo o inverso nos genótipos tolerante e intermediário, K191 e T21, respectivamente.

Em trabalhos com aveia, Bilski \& Foy (1987) e Floss (1992) determinaram valores decrescentes na relação MSR/MSPA com a elevação do nivel de alumínio no substrato e concluíram que nessa espécie as raízes são mais susceptiveis à toxicidade do que a parte aérea. Baligar et al. (1993) relataram fato semelhante determinado em plantas de sorgo com tolerância diferencial ao alumínio. Por outro lado, estudando as forrageiras Brachiaria decumbens e Cenchrus ciliaris, respectivamente tolerante e sensível ao alumínio, Fernandes et al. (1984) não encontraram diferença significativa na relação MSR/MSPA, 
quando compararam a adição de $6 \mathrm{mg}$ de $\mathrm{Al} \mathrm{L}^{-1}$ com a omissão desse elemento na solução nutritiva.

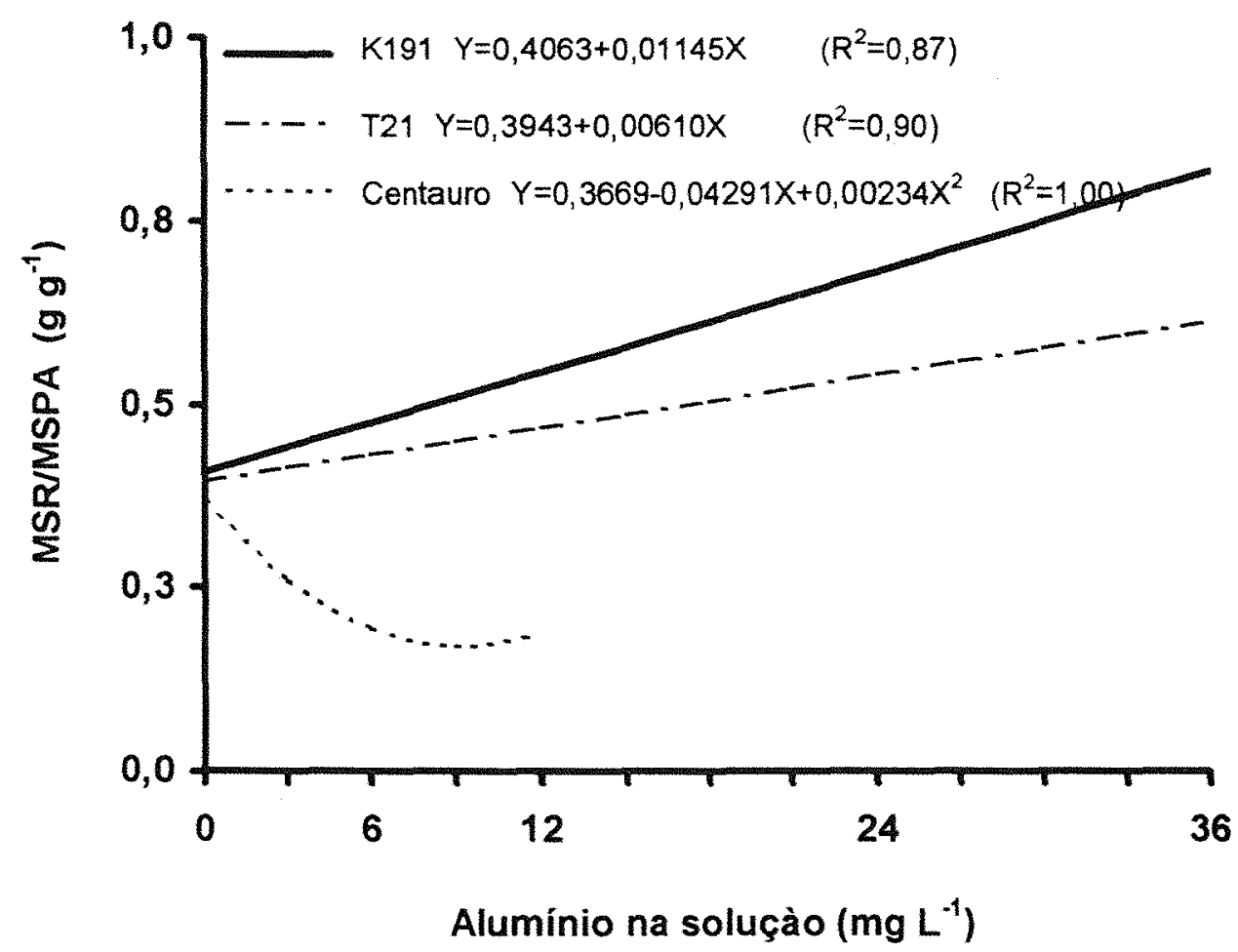

Figura 21- Relação entre as produções de matéria seca de raizes e de parte aérea (MSR/MSPA) em três genótipos de Panicum maximum, em função das doses de aluminio na solução nutritiva.

\subsubsection{Concentração e acúmulo de alumínio e macronutrientes}

\subsubsection{Concentração e acúmulo de alumínio}

A análise de variância para a concentração de alumínio na parte aérea, bem como nas raizes das plantas de Panicum maximum mostrou significância $(\mathrm{P}<0,01)$ para a interação entre genótipos e doses de alumínio.

Através da comparação entre médias dos genótipos dentro de cada dose de alumínio pelo teste de Tukey, observa-se que na dose $0 \mathrm{mg}$ de $\mathrm{Al} \mathrm{L}^{-1}$ os genótipos não diferiram significativamente $(\mathrm{P}>0,05)$ quanto à concentração de 
alumínio, tanto nas raízes (Figura 22), quanto na parte aérea das plantas (Figura 23). Na Figura 22 observa-se que nas doses 12,24 e $36 \mathrm{mg}$ de $\mathrm{Al} \mathrm{L}^{-1}$ o K191 apresentou maior concentração de alumínio na raízes que T21 e Centauro. Para a concentração de alumínio na parte aérea, o teste de Tukey não evidenciou diferenças significativas $(\mathrm{P}>0,05)$ entre os três genótipos nas doses de alumínio de 0 e $6 \mathrm{mg} \mathrm{L}^{-1}$. O cultivar Centauro mostrou maior concentração de alumínio na parte aérea na dose de $12 \mathrm{mg}$ de $\mathrm{Al} \mathrm{L}^{-1}$. Na maior dose de alumínio em solução a concentração de alumínio na parte aérea do K191 superou a do T21.

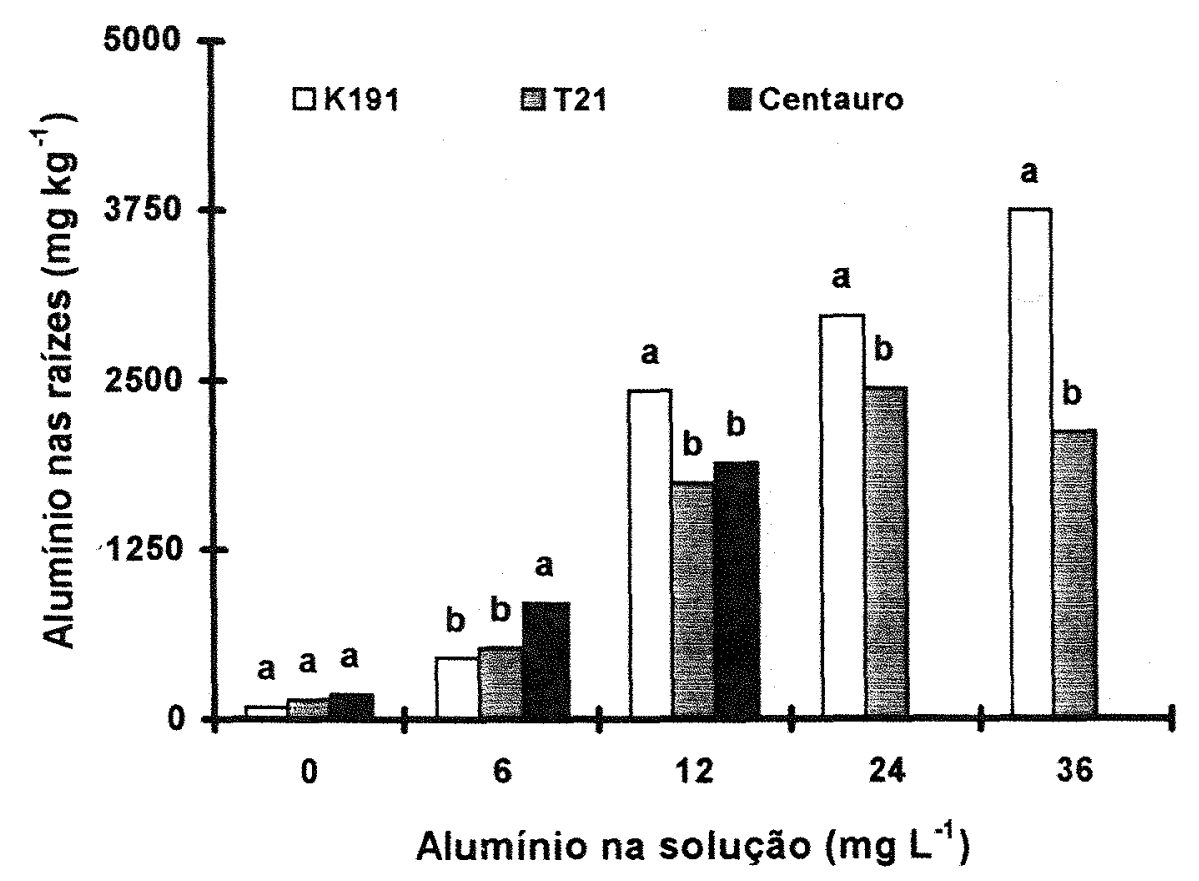

Figura 22- Concentração de aluminio nas raizes de três genótipos de Panicum maximum, em função das doses de alumínio na solução nutritiva. (Letras comparam genótipos dentro de cada dose de alumínio pelo teste de Tukey a $5 \%$ ). 


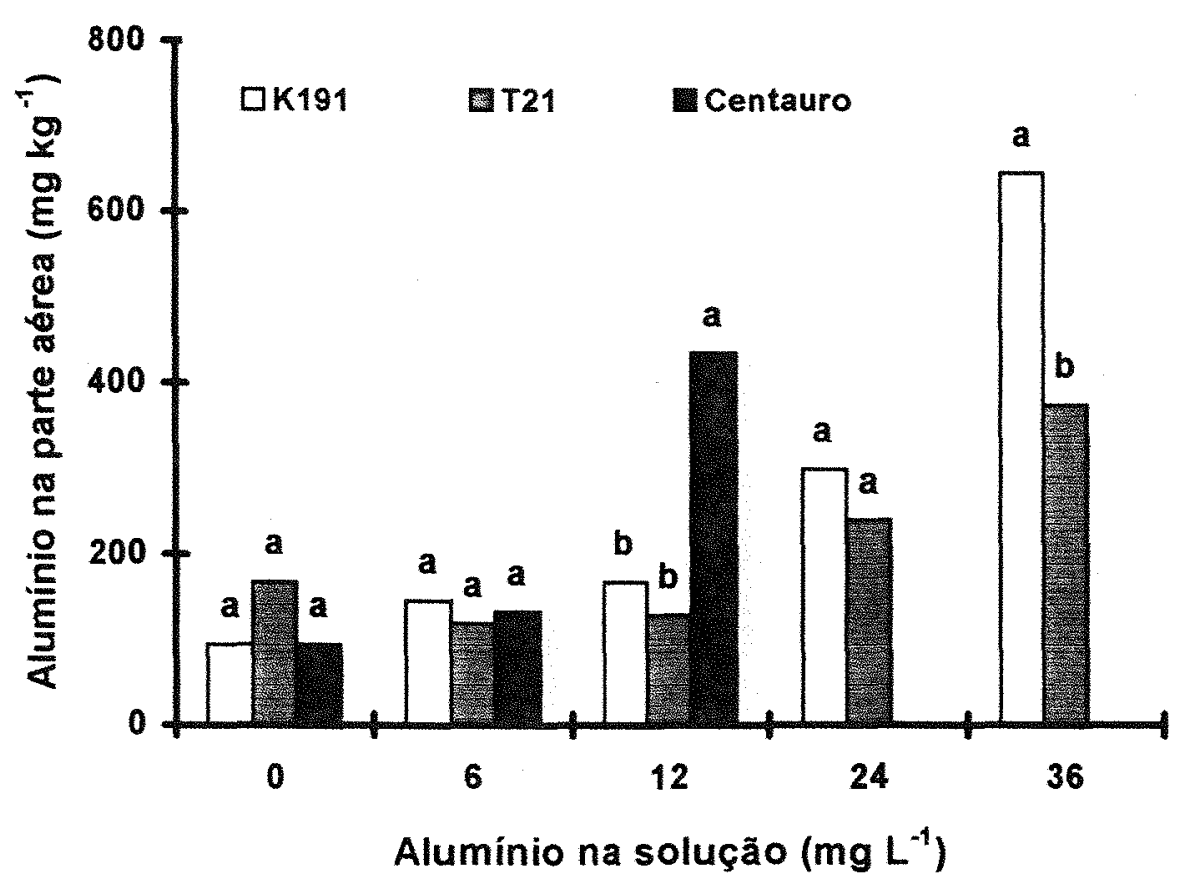

Figura 23 - Concentração de alumínio na parte aérea de três genótipos de Panicum maximum, em função das doses de alumínio na solução nutritiva. (Letras comparam genótipos dentro de cada dose de alumínio pelo teste de Tukey a 5\%).

As concentrações de alumínio, tanto na parte aérea quanto nas raizes variou com a adição de alumínio na solução nutritiva. Para as raizes (Figura 24) dos genótipos tolerante e intermediário o comportamento foi representado por modelo quadrático, com máximas concentrações nas doses 39 e $28 \mathrm{mg}$ de $\mathrm{Al} \mathrm{L}^{-1}$, respectivamente, enquanto que no sensível o acréscimo foi linear.

A análise de regressão ajustou modelos quadráticos para a variação da concentração de alumínio na parte aérea (Figura 25). Observa-se que para atingir a concentração $430 \mathrm{mg}$ de $\mathrm{Al} \mathrm{kg}^{-1}$ de matéria seca da parte aérea o cultivar Centauro necessitou do fornecimento de $12 \mathrm{mg}$ de $\mathrm{Al} \mathrm{L}^{-1}$ de solução nutritiva, enquanto que, para a mesma concentração, o K191 teve que receber $30 \mathrm{mg}$ de $\mathrm{Al}$ $\mathrm{L}^{-1}$ de solução. Esse fato possivelmente esteja associado à tolerância ao excesso de alumínio apresentada pelo K191. 


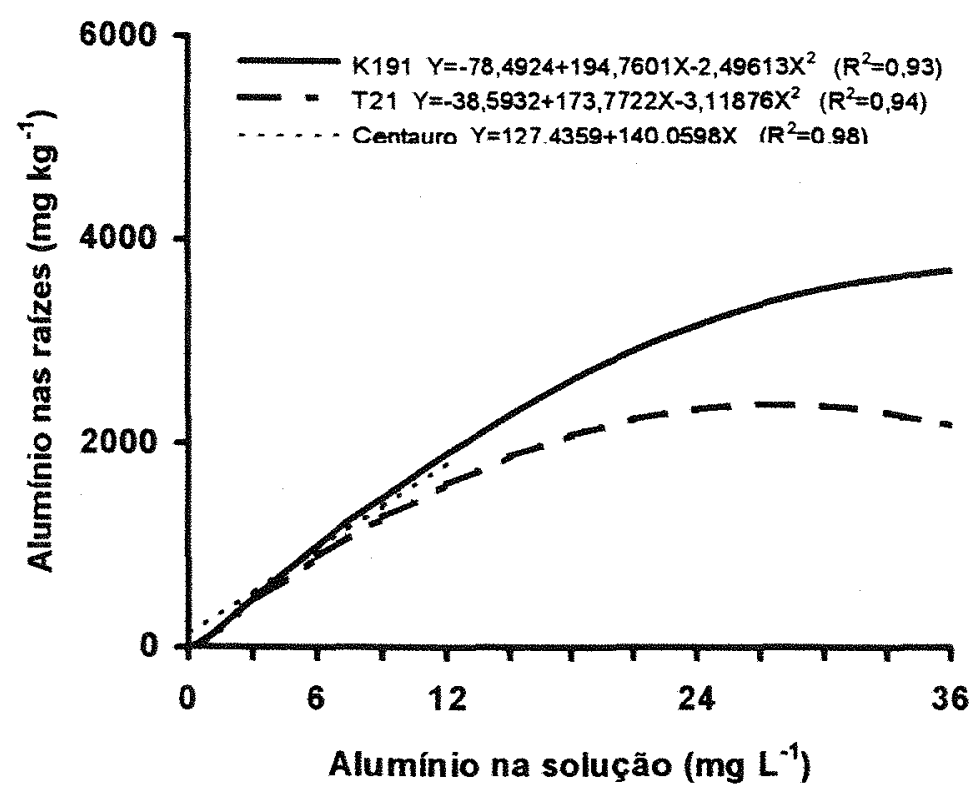

Figura 24 - Concentração de alumínio nas raizes dos genótipos de Panicum maximum, em função das doses de alumínio na solução nutritiva.

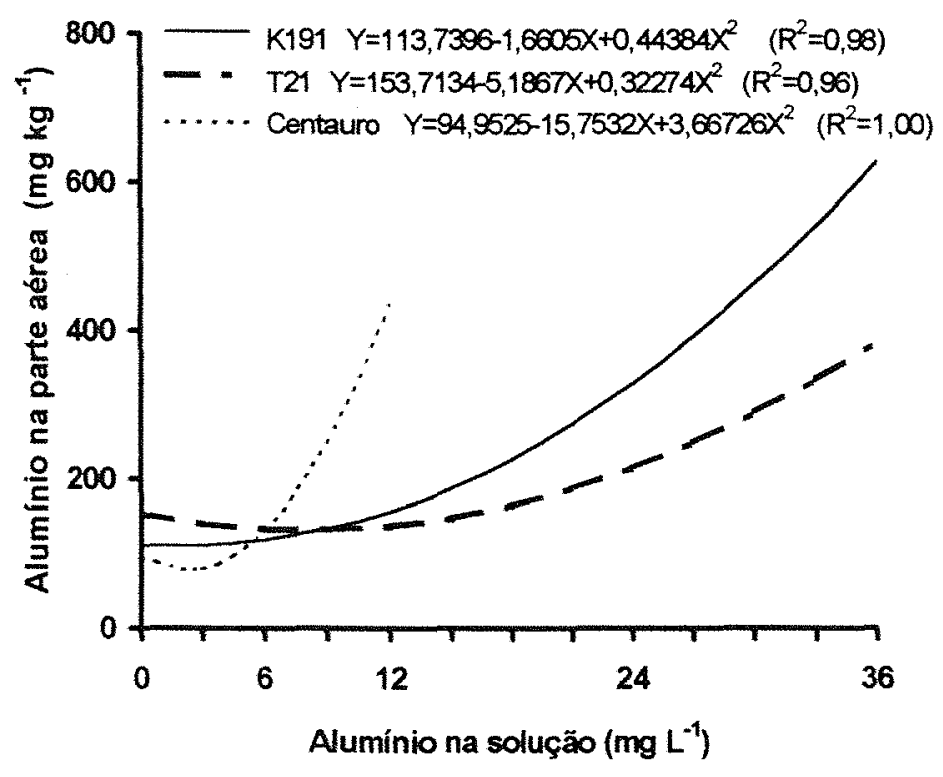

Figura 25 - Concentração de alumínio na parte aérea dos genótipos de Panicum maximum, em função das doses de alumínio na solução nutritiva. 
Foy et al. (1967) associaram a tolerância diferencial ao alumínio com a capacidade de absorção, transporte e acúmulo de alumínio pelas plantas, de forma que genótipos tolerantes mostraram redução na absorção desse elemento ou então imobilizaram-no após a absorção, ou translocaram menos alumínio para a parte aérea.

Em geral as concentrações de alumínio nas raizes tiveram valores mais elevados, até $3750 \mathrm{mg}$ de $\mathrm{Al} \mathrm{kg}^{-1}$, que aqueles encontrados na parte aérea das plantas, aproximadamente $600 \mathrm{mg}$ de $\mathrm{Al} \mathrm{kg}^{-1}$. Calbo \& Cambraia (1980) verificaram resultados semelhantes em cultivares de sorgo, que apresentaram quantidades consideráveis de alumínio no protoplasma das células das raizes, o que indica a existência de um possível mecanismo interno de desintoxicação. Estes resultados também concordam com os relatos de Rengel \& Robinson (1989) e Huang \& Grunes (1992) que também encontraram concentração mais elevada de alumínio nas raizes do que na parte aérea de centeio e trigo forrageiro, respectivamente. McCormick \& Borden (1972) e Foy et al. (1978) referiram que em plantas estressadas por alumínio, esse elemento frequentemente se concentra nas raízes e não na parte aérea da plantas.

Wheeler et al. (1992), estudando o efeito do alumínio na nutrição mineral de 28 cultivares de gramíneas forrageiras de clima temperado, verificaram que a adição do elemento na solução nutritiva determinou aumentos na concentração de alumínio de 38 a $104 \mathrm{mg}$ de $\mathrm{Al} \mathrm{kg}^{-1}$ de matéria seca da parte aérea, e de 370 a $3843 \mathrm{mg}$ de $\mathrm{Al} \mathrm{kg}^{-1}$ de matéria seca das raízes.

As plantas cultivadas na solução nutritiva completa (sem $\mathrm{Al}$ ) apresentaram concentrações de alumínio variando de 95 a $140 \mathrm{mg} \mathrm{de} \mathrm{Al} \mathrm{kg}^{-1}$ de matéria seca da parte aérea. Nas raízes destas mesmas plantas os valores para a concentração de alumínio foram mais baixos. Em genótipos de aveia, Floss (1992) verificou concentrações de 126 e $98 \mathrm{mg}$ de $\mathrm{Al} \mathrm{kg}^{-1}$ de matéria seca, 
respectivamente nas plantas tolerante e sensivel, quando cultivadas em solução sem alumínio.

A interação genótipos $\mathrm{x}$ doses de alumínio também foi significativa $(\mathrm{P}<0,01)$ para o acúmulo de alumínio na parte aérea, bem como nas raízes dos capins.

A comparação entre médias dos genótipos dentro de cada dose de alumínio (Figura 26) mostrou que para o acúmulo de alumínio nas raizes, nas doses de alumínio de 0 e $6 \mathrm{mg} \mathrm{L}^{-1}$ o teste de Tukey não detectou diferenças significativas entre os três capins. Com a adição da dose de aluminio de $12 \mathrm{mg} \mathrm{L}^{-1}$ de solução as plantas de K191 apresentaram maior concentração que as de Centauro, e maior que as de $\mathrm{T} 21 \mathrm{em} 36 \mathrm{mg}$ de $\mathrm{Al} \mathrm{L}^{-1}$.

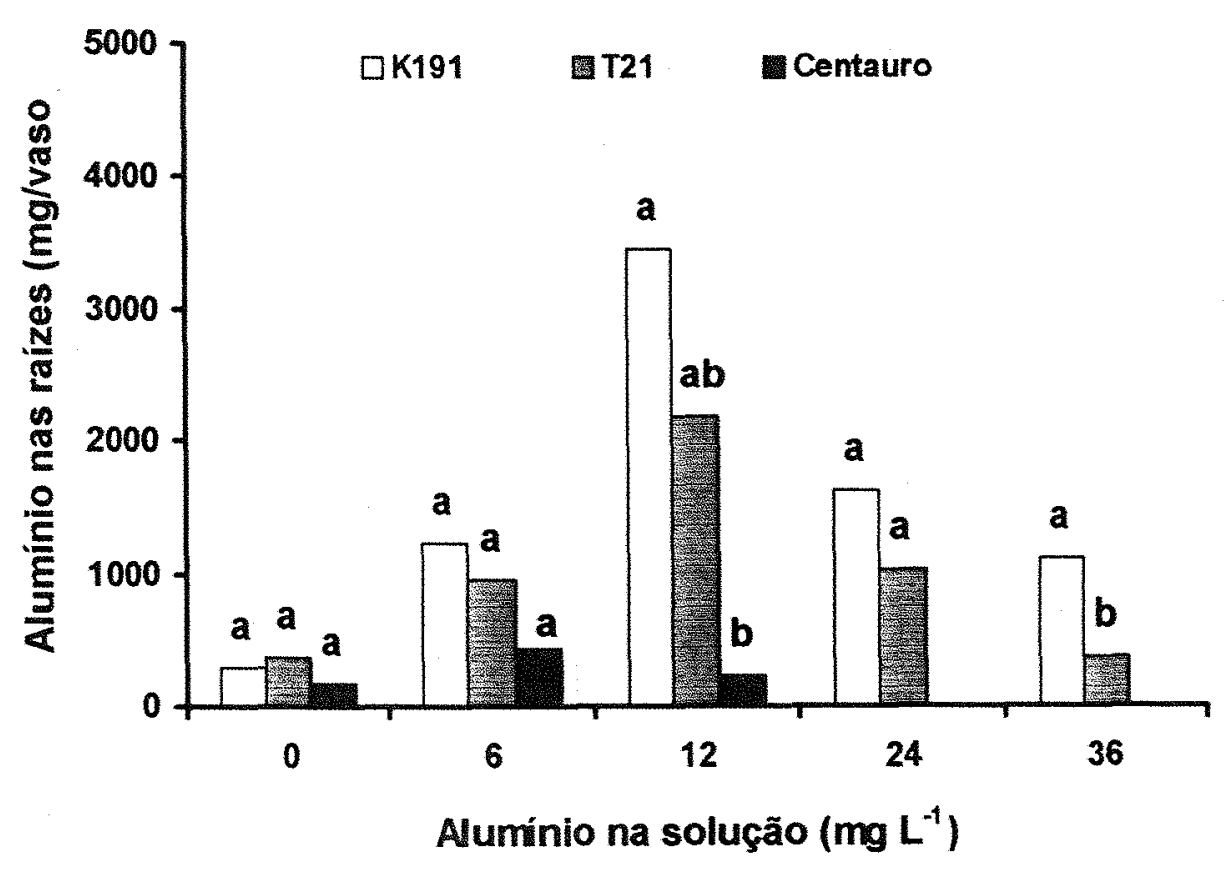

Figura 26 - Acúmulo de alumínio nas raizes de três genótipos de Panicum maximum, em função das doses de alumínio na solução nutritiva. (Letras comparam genótipos dentro de cada dose de alumínio pelo teste de Tukey a $5 \%$ ). 
Na Figura 27 observa-se que na omissão de alumínio o genótipo T21 apresentou maior acúmulo de alumínio na parte aérea que o Centauro, e ambos não diferiram de $\mathrm{K} 191$. Na dose de alumínio de $6 \mathrm{mg} \mathrm{L}^{-1}$ o $\mathrm{K} 191$ superou os genótipos T21 e Centauro no acúmulo de alumínio na parte aérea. Quando se adicionou 24 e $36 \mathrm{mg}$ de $\mathrm{Al}$ por litro de solução os genótipos K191 e T21 não diferiram entre si pelo teste de Tukey $(\mathrm{P}>0,05)$.

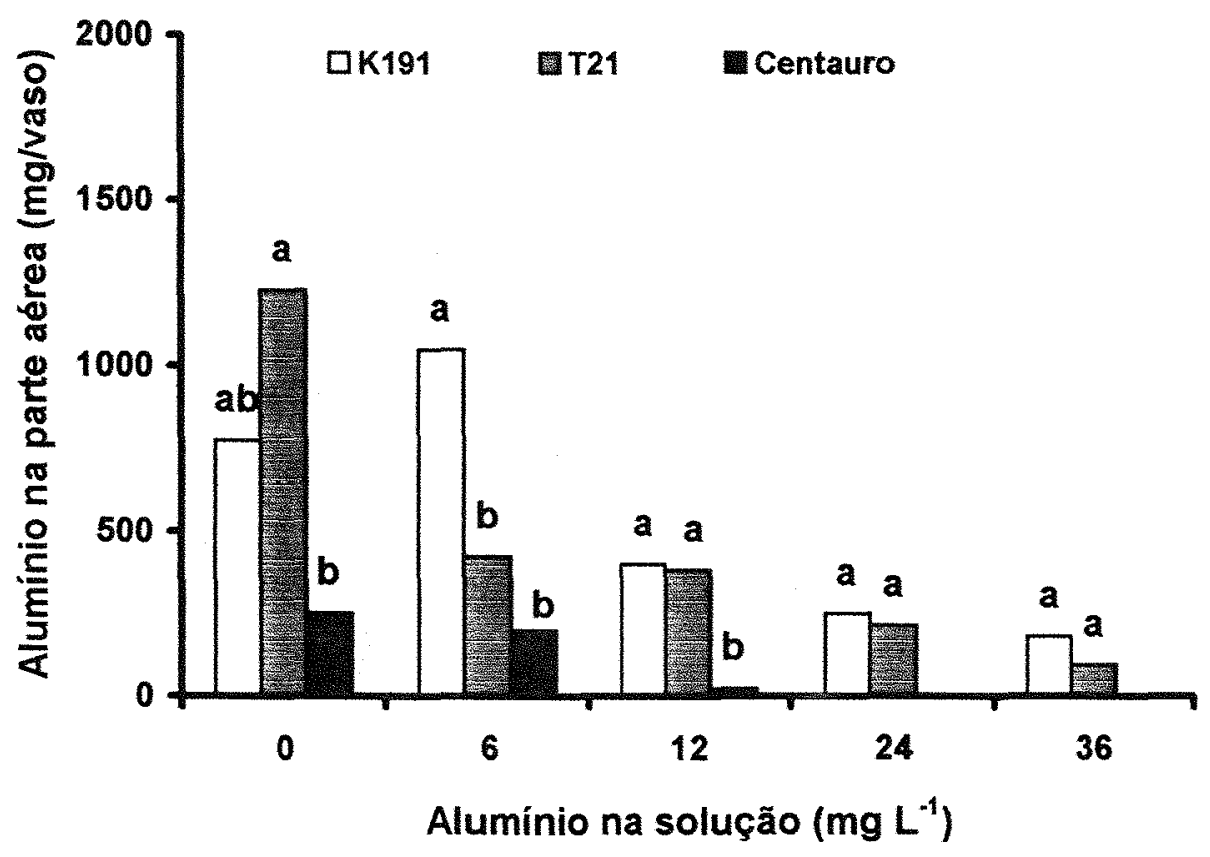

Figura 27 - Acúmulo de alumínio na parte aérea de três genótipos de Panicum maximum, em função das doses de alumínio na solução nutritiva. (Letras comparam genótipos dentro de cada dose de alumínio pelo teste de Tukey a $5 \%$ ).

A análise de regressão do efeito das doses de alumínio para o acúmulo de alumínio, ajustou modelos matemáticos de segundo grau para as raízes de T21 e K.191, com pontos de máximo em 17 e $19 \mathrm{mg}$ de $\mathrm{Al} \mathrm{L}^{-1}$ (Figura 28). Para a parte aérea das plantas de K191 o acúmulo decresce linearmente com as doses (Figura 29) enquanto que para T21 o acúmulo de alumínio é mínimo em $26 \mathrm{mg}$ de $\mathrm{Al} \mathrm{L}^{-1}$. 


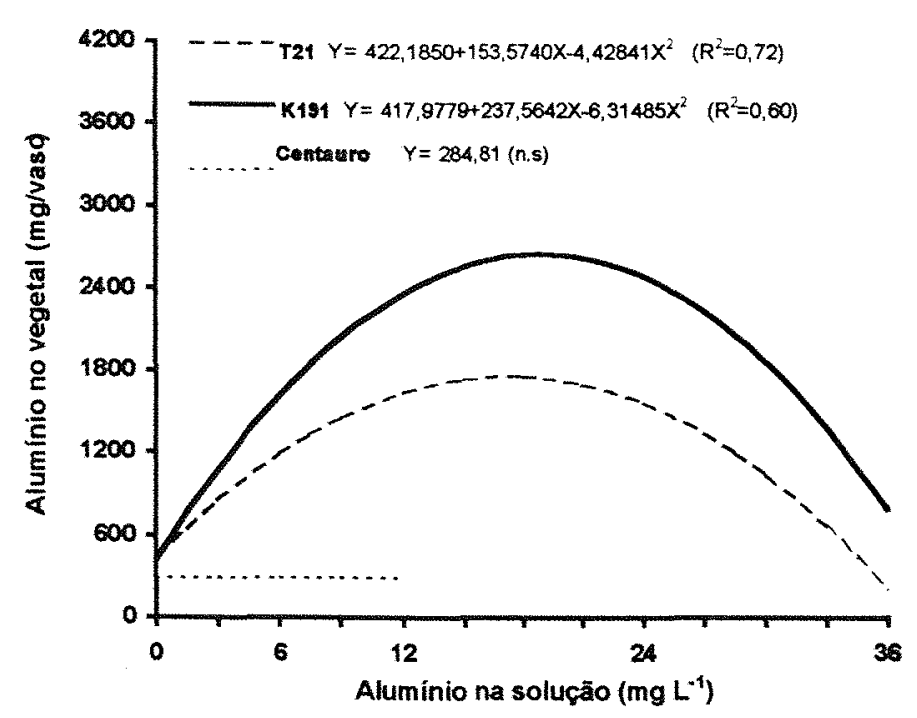

Figura 28 - Acúmulo de alumínio nas raízes dos genótipos de Panicum maximum, em função das doses de alumínio na solução nutritiva.

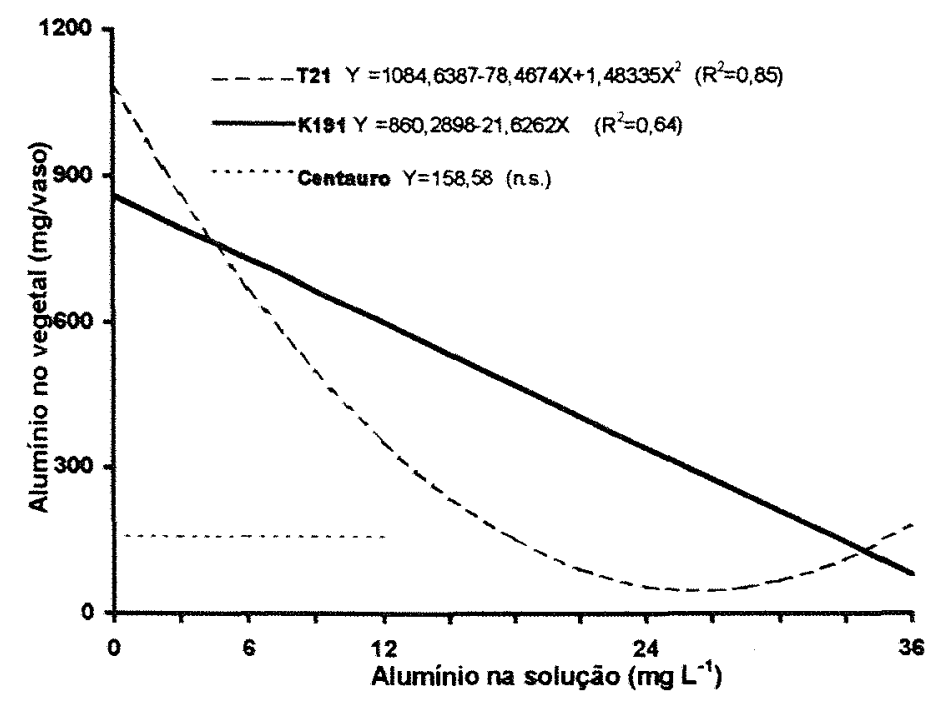

Figura 29 - Acúmulo de alumínio na parte aérea dos genótipos de Panicum maximum, em função das doses de alumínio na solução nutritiva.

Considerando o acúmulo de alumínio entre os órgãos vegetativos, demonstrado na Figura 30, nota-se que na omissão de alumínio os genótipos K191 e T21 acumularam alumínio preferencialmente nas lâminas foliares, enquanto que para o Centauro o acúmulo de alumínio é praticamente equivalente nas lâminas foliares e nas raízes. Para todos os genótipos avaliados, à medida em 
que se elevou a dose de alumínio, esse elemento passou a ser acumulado nas raízes das plantas.

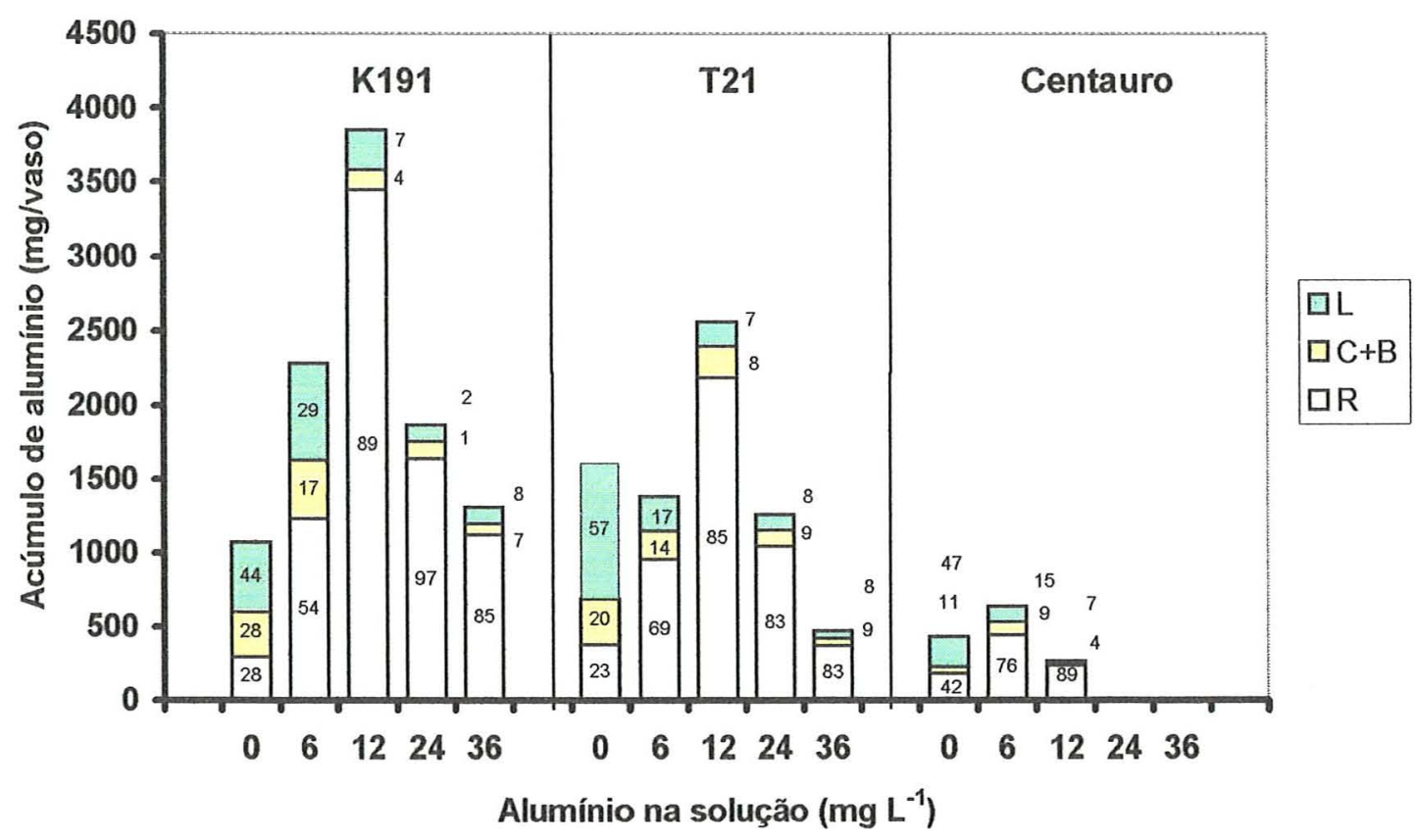

Figura 30- Distribuição porcentual de alumínio entre órgãos vegetativos dos genótipos de Panicum maximum em função das doses de alumínio. (Os números dentro ou ao lado das colunas referem-se ao porcentual de cada componente em relação à matéria seca total).

Wheeler et al. (1992) afirmaram que para gramíneas de clima temperado o alumínio acumulou-se mais nas raízes que na parte aérea. Segundo Foy (1983) o acúmulo de alumínio nas raízes não indica necessariamente susceptibilidade da

planta a esse elemento. Em trabalho com arroz, Thawornwong \& Van Diest (1974) concluíram que o conteúdo de alumínio não é um índice adequado para tolerância ao alumínio.

Considerando os resultados para concentração de alumínio na parte aérea e raízes e a distribuição porcentual do alumínio acumulado nas plantas pode-se inferir que, no caso de diagnose da fitotoxicidade do alumínio, a parte aérea da 
gramínea (ou seja, tanto os colmos + bainhas como as lâminas foliares) não é parte da planta indicada para o diagnóstico.

\subsubsection{Concentração e acúmulo de cálcio}

$\mathrm{O}$ teste $\mathrm{F}$ revelou que a interação genótipo $\mathrm{x}$ dose de alumínio foi significativa $(\mathrm{P}<0,01)$ para a concentração de cálcio na parte aérea dos capins estudados.

Através da comparação entre médias dos genótipos (Figura 31) observase que na omissão de alumínio na solução, a concentração de cálcio na parte aérea das plantas de K191 e de Centauro foi superior àquela de T21. Na dose de alumínio de $6 \mathrm{mg} \mathrm{L}^{-1}$ o genótipo tolerante K191 mostrou concentração de cálcio mais elevada na parte aérea quando comparado aos genótipos intermediário (T21) e sensível (Centauro). Observa-se que nas mais altas doses de alumínio o teste de Tukey não evidenciou diferença entre os genótipos.

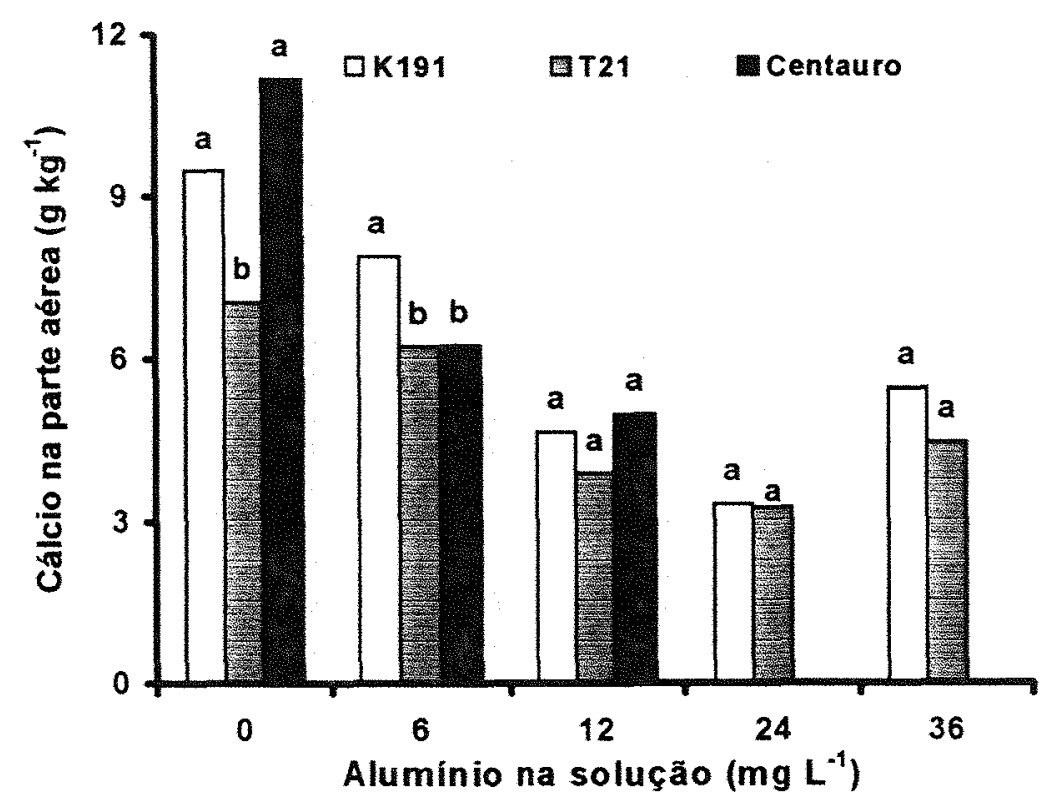

Figura 31 - Concentração de cálcio na parte aérea de três genótipos de Panicum maximum, em função das doses de alumínio na solução nutritiva. (Letras comparam genótipos dentro de cada dose de alumínio pelo teste de Tukey a $5 \%$ ). 
Considerando que o Centauro mostrou extrema sensibilidade ao excesso de alumínio em solução, visto que as plantas morreram quando submetidas às doses 24 e $36 \mathrm{mg}$ de $\mathrm{Al} \mathrm{L}^{-1}$, o teor comparativamente alto de cálcio apresentado por esse capim na dose $12 \mathrm{mg}$ de $\mathrm{Al} \mathrm{L}^{-1}$ foi resultante do efeito de concentração do elemento na reduzida produção de matéria seca.

A análise de regressão ajustou a representação da redução na concentração de cálcio na parte aérea dos capins de forma quadrática para os genótipos tolerante e intermediário e linear para o cultivar sensível (Figura 32).

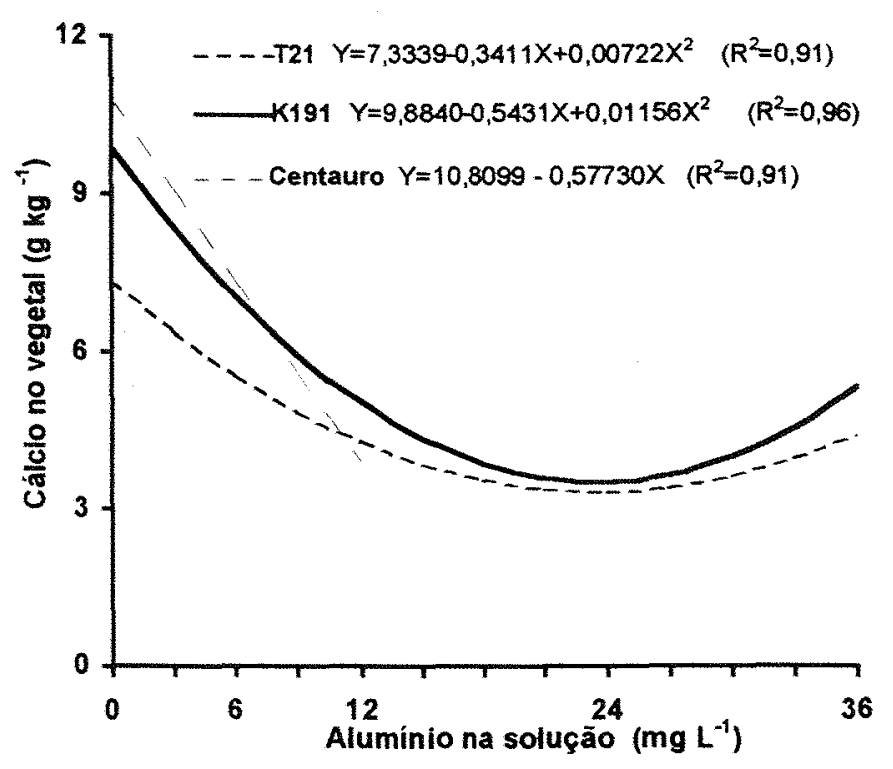

Figura 32 - Concentração de cálcio na parte aérea dos genótipos de Panicum maximum em função da dose de alumínio na solução nutritiva.

Observa-se que, para os capins K191 e T21, a máxima redução na concentração de cálcio na parte aérea ocorreu com a adição de 23,5 e 23,6 mg de alumínio por litro da solução nutritiva, respectivamente. Em condições de excesso de alumínio é comum ocorrer baixa concentração de cálcio nos tecidos vegetais. Essa redução na concentração de cálcio na parte aérea das plantas estressadas pelo alumínio é relatada na literatura (Foy et al., 1978; Roy et al., 1988; Taylor, 
1988; Wilkinson \& Duncan, 1993). A redução na absorção de cálcio na presença de alumínio no substrato tem sido interpretada como uma das causas da toxicidade do alumínio em plantas de arroz (Sivaguru \& Paliwal, 1993).

Com relação ao acúmulo de cálcio na parte aérea dos três capins estudados, a análise de variância mostrou que a interação entre genótipos e doses de alumínio foi significativa $(\mathrm{P}<0,01)$.

A comparação entre médias dos genótipos dentro de cada dose de alumínio (Figura 33) mostrou que o acúmulo de cálcio na parte aérea das plantas do K191 foi superior a do Centauro, em qualquer das doses testadas. Apenas na dose de alumínio de $6 \mathrm{mg} \mathrm{L}^{-1}$ o genótipo tolerante T21 mostrou menor acúmulo de cálcio na parte aérea quando comparado ao genótipo tolerante K191. Nas duas doses mais altas de alumínio o teste de Tukey não evidenciou diferença entre os capins K191 e T21. Verifica-se que o acúmulo de cálcio pelo cultivar sensível foi inferior àquele do K191. Sivaguru \& Paliwal (1993) afirmaram que gramíneas sensíveis ao alumínio acumularam menos cálcio nas folhas, indicando que a toxicidade reduz não só a absorção como também o transporte de cálcio das raízes para a parte aérea do vegetal.

A análise de regressão para as doses de alumínio com relação ao acúmulo de cálcio na parte aérea ajustou modelos quadráticos ao comportamento dos capins K191 e T21 (Figura 34). O acúmulo de cálcio foi limitado pelo incremento de alumínio na solução nutritiva. Resultados similares foram relatados para soja (Foy et al.,1969), sorgo (Furlani \& Clark, 1981) e aveia (Floss, 1992), os quais relataram que plantas expostas ao alumínio acumulam menos cálcio. 


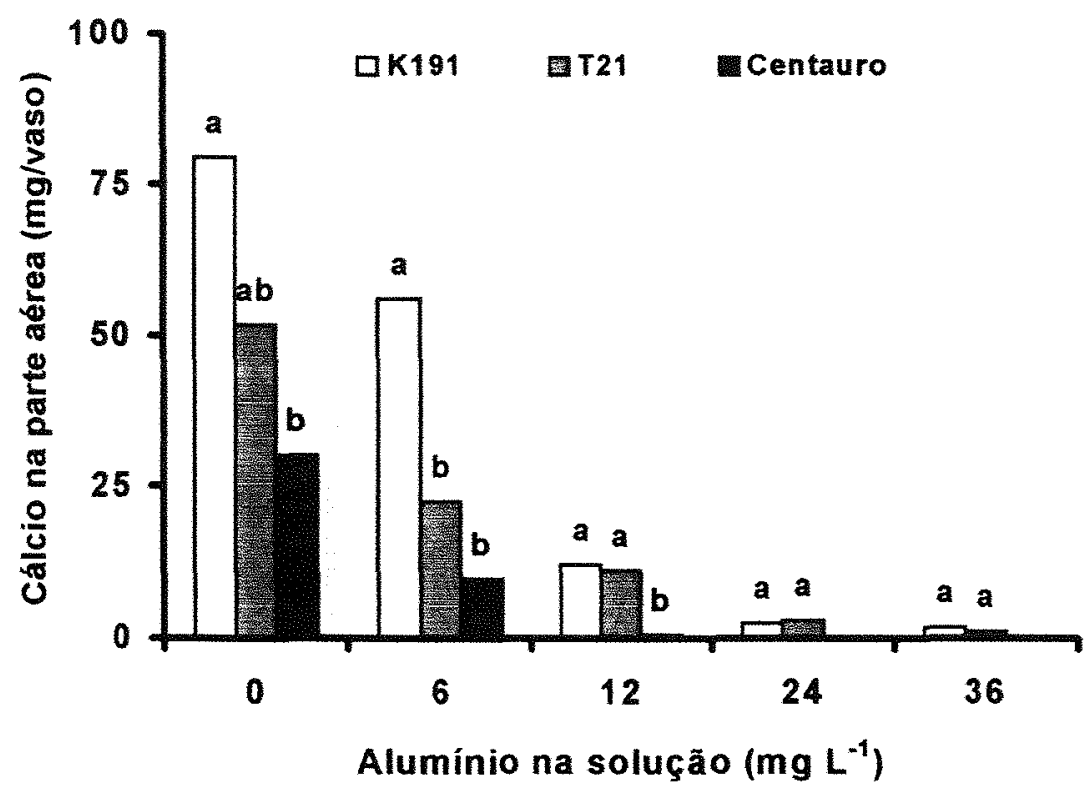

Figura 33 - Acúmulo de cálcio na parte aérea dos genótipos de Panicum maximum, em função da dose de alumínio na solução nutritiva. (Letras comparam genótipos dentro de cada dose de alumínio pelo teste de Tukey a $5 \%$ ).

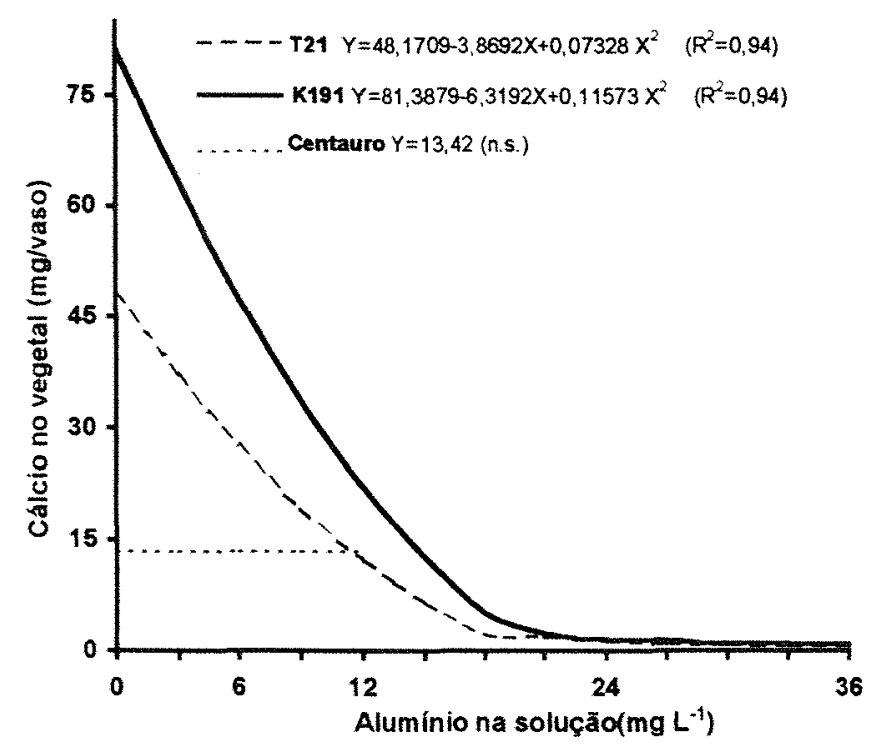

Figura 34 - Acúmulo de cálcio na parte aérea dos genótipos de Panicum maximum, em função da dose de alumínio na solução nutritiva. 
Quanto à concentração de cálcio nas raízes, a análise de variância revelou significância $(\mathrm{P}<0,01)$ para a interação entre genótipos e doses de alumínio.

No desdobramento dessa interação, o teste de Tukey para a comparação entre médias dos genótipos (Figura 35) mostrou que nas doses 0 e $6 \mathrm{mg}$ de $\mathrm{Al} \mathrm{L}^{-1}$ os capins não diferiram quanto a concentração de cálcio nas raízes. Nas doses mais altas de alumínio o genótipo tolerante K191 mostrou concentração de cálcio mais baixa nas raízes quando comparado ao T21. Essas observações indicam que as plantas de K191 foram mais eficientes no transporte de cálcio para a parte aérea comparadas às plantas de T21 e Centauro. Resultados semelhantes foram discutidos por Huang et al. (1993), que trabalhando com trigo forrageiro, verificaram inibição significativa da absorção e da translocação de cálcio quando as plantas sensiveis foram expostas ao alumínio.

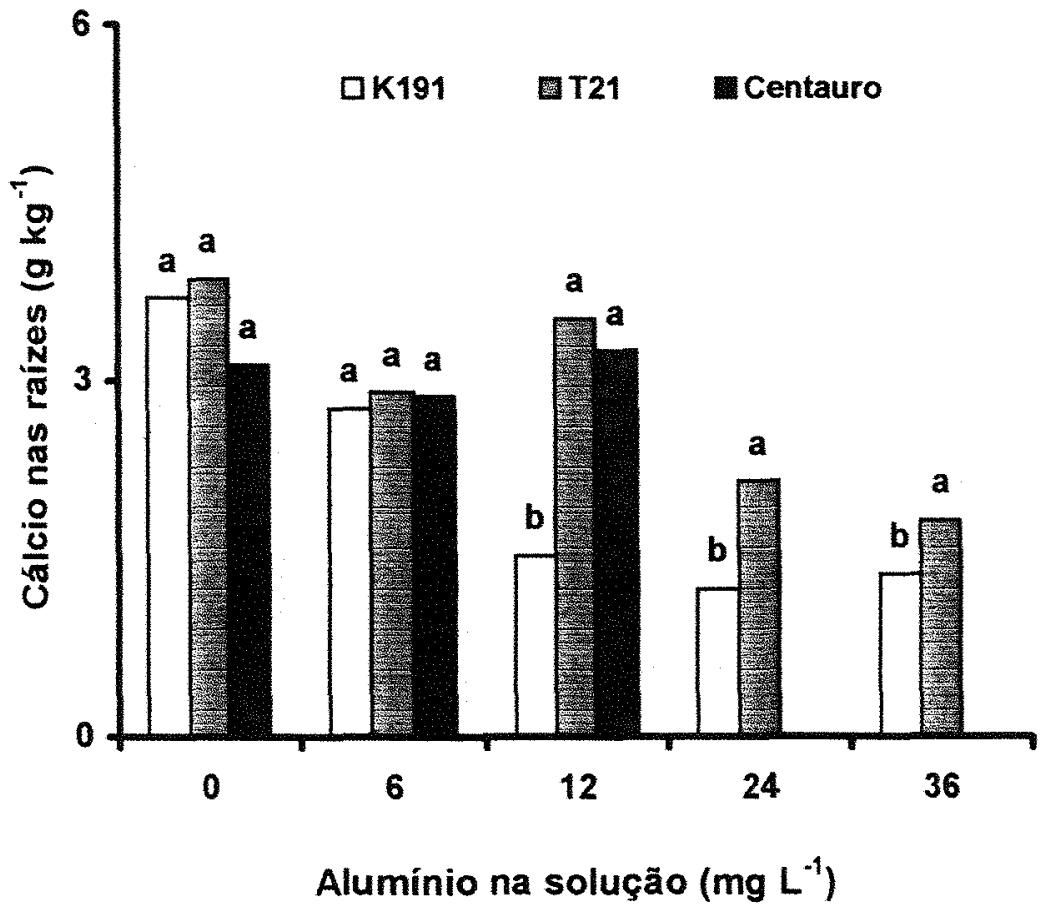

Figura 35 - Concentração de cálcio nas raizes de três genótipos de Panicum maximum, em função das doses de alumínio na solução nutritiva. (Letras comparam genótipos dentro de cada dose de aluminio pelo teste de Tukey a $5 \%$ ). 
A fim de descrever a variação na concentração de cálcio nas raízes dos capins, o estudo de regressão ajustou um modelo linear para o comportamento de T21 e outro quadrático para K191 (Figura 36).

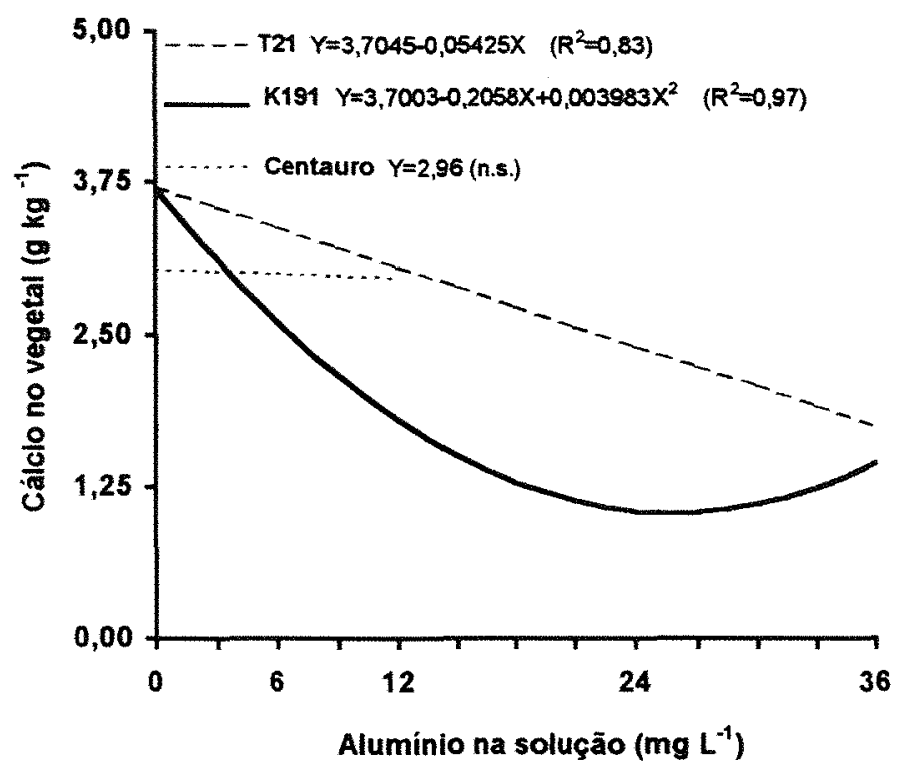

Figura 36 - Concentração de cálcio nas raízes dos genótipos de Panicum maximum, em função da dose de alumínio na solução nutritiva.

A análise de variância mostrou que a interação entre genótipos e doses de alumínio foi significativa $(\mathrm{P}<0,01)$ para o acúmulo de cálcio nas raízes.

A comparação entre médias dos genótipos dentro de cada dose de alumínio (Figura 37) mostrou que nas doses de alumínio de 0 e $6 \mathrm{mg} \mathrm{L}^{-1}$ o acúmulo de cálcio nas raizes de Centauro foi menor que o das raizes de K191 e T21. Na dose de alumínio de $12 \mathrm{mg} \mathrm{L}^{-1}$ o genótipo intermediário $\mathrm{T} 21$ mostrou maior acúmulo de cálcio nas raizes quando comparado aos genótipos tolerante $\mathrm{e}$ sensível. Nas maiores doses de alumínio o teste de Tukey não evidenciou diferença entre os capins K191 e T21, e nessa situação o acúmulo de cálcio nas raizes de ambos foi muito baixa.

A análise de regressão ajustou equações de segundo grau ao efeito das doses de alumínio no acúmulo de cálcio das raízes dos genótipos tolerante e intermediário, K191 e T21, respectivamente (Figura 38). 


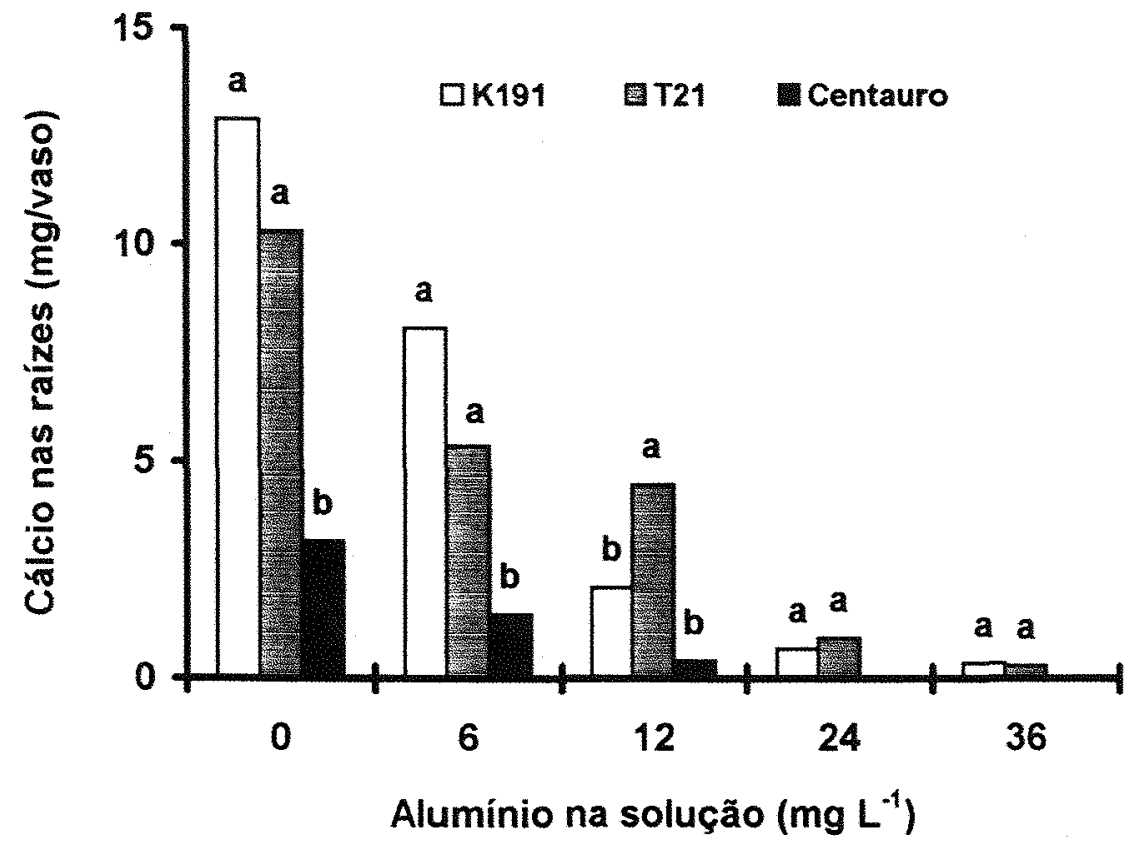

Figura 37 - Acúmulo de cálcio nas raizes de três genótipos de Panicum maximum, em função das doses de alumínio na solução nutritiva. (Letras comparam genótipos dentro de cada dose de aluminio pelo teste de Tukey a 5\%).

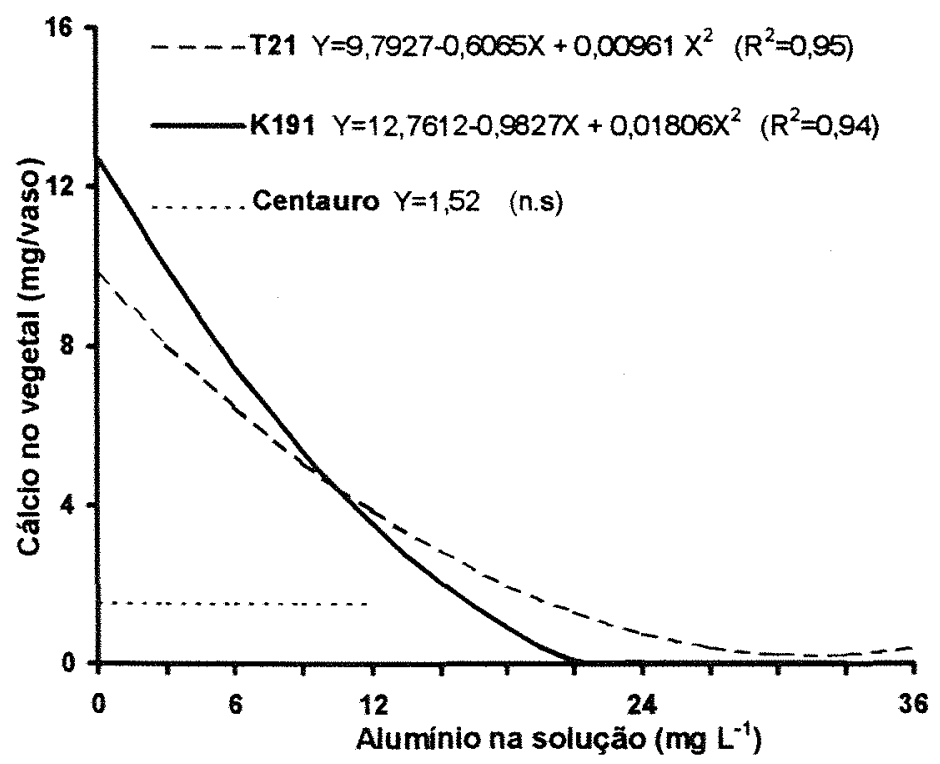

Figura 38 - Acúmulo de cálcio nas raízes dos genótipos de Panicum maximum, em função da dose de alumínio na solução nutritiva. 
Considerando a distribuição percentual do cálcio acumulado na planta (Figura 39), verifica-se que todos os genótipos acumularam menos cálcio nas raízes do que na parte aérea. À medida que o alumínio foi incrementado ao meio de crescimento a distribuição porcentual do acúmulo de cálcio nas raízes se elevou. Na dose $12 \mathrm{mg} \mathrm{Al} \mathrm{L}^{-1}$ o porcentual distribuído de cálcio nas raízes do cultivar Centauro superou o dos demais genótipos e mostrou valor mais elevado que o da parte aérea da planta. Essa característica decorre do grande efeito depressivo do alumínio na produção de matéria seca radicular destas plantas, bem como possível inibição da translocação de cálcio para a parte aérea, como proposto por Huang et al. (1993).

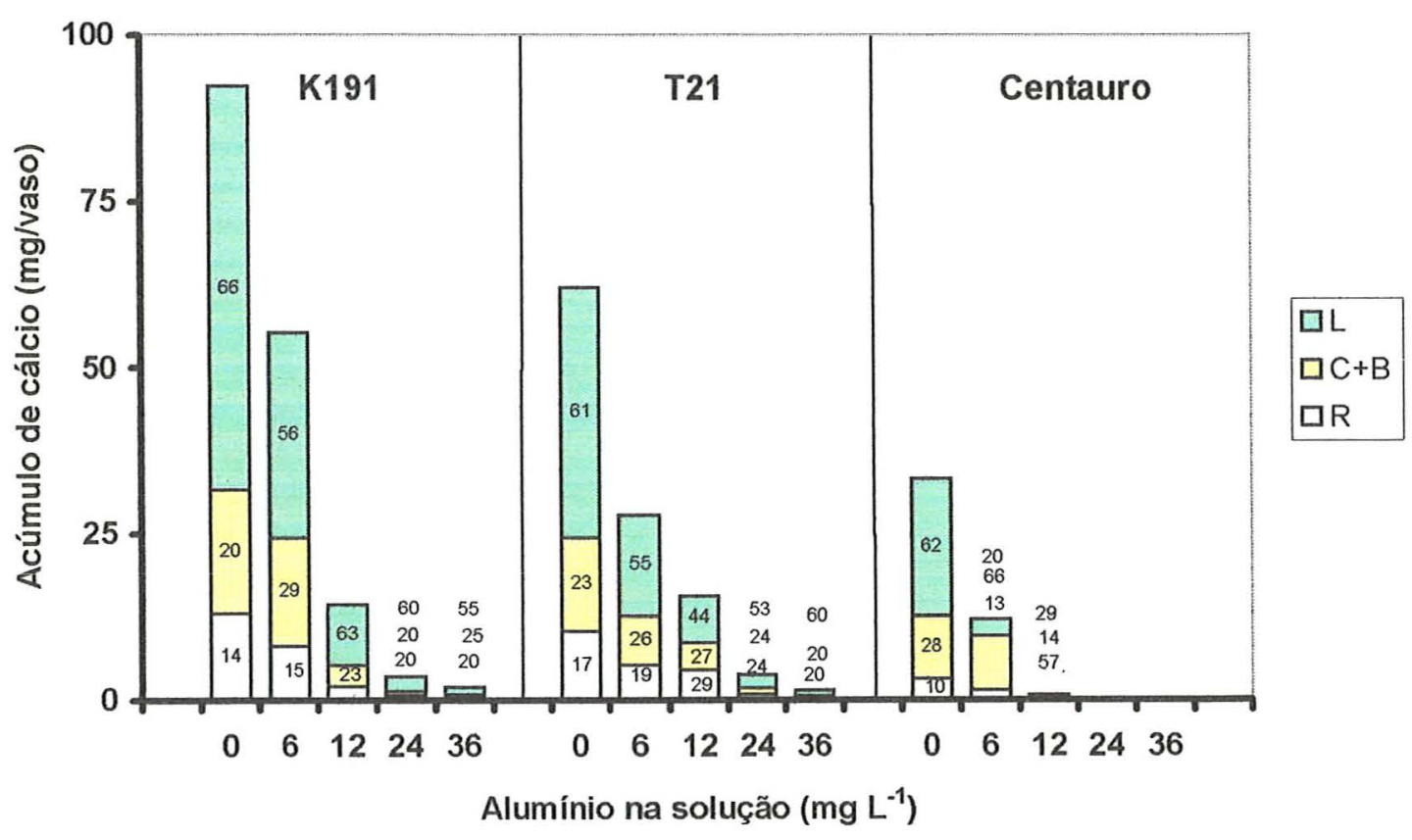

Figura 39- Distribuição percentual do acúmulo de cálcio entre órgãos vegetativos da planta em função das doses de alumínio. (Os números dentro ou ao lado das colunas referem-se ao porcentual de cada componente em relação à matéria seca total). 


\subsubsection{Concentração e acúmulo de fósforo}

A concentração de fósforo na parte aérea dos capins foi significativamente influenciada $(\mathrm{P}<0,01)$ pela interação genótipos $\mathrm{x}$ doses de alumínio.

A comparação entre médias dos genótipos dentro de cada dose de alumínio (Figura 40) mostrou que na ausência de alumínio na solução, a concentração de fósforo na parte aérea das plantas de K191 e T21 foi mais baixa que a de Centauro. Nas doses de alumínio de 6 e $12 \mathrm{mg} \mathrm{L}^{-1}$ os genótipos não apresentaram diferenças quanto a concentração de fósforo na parte aérea.

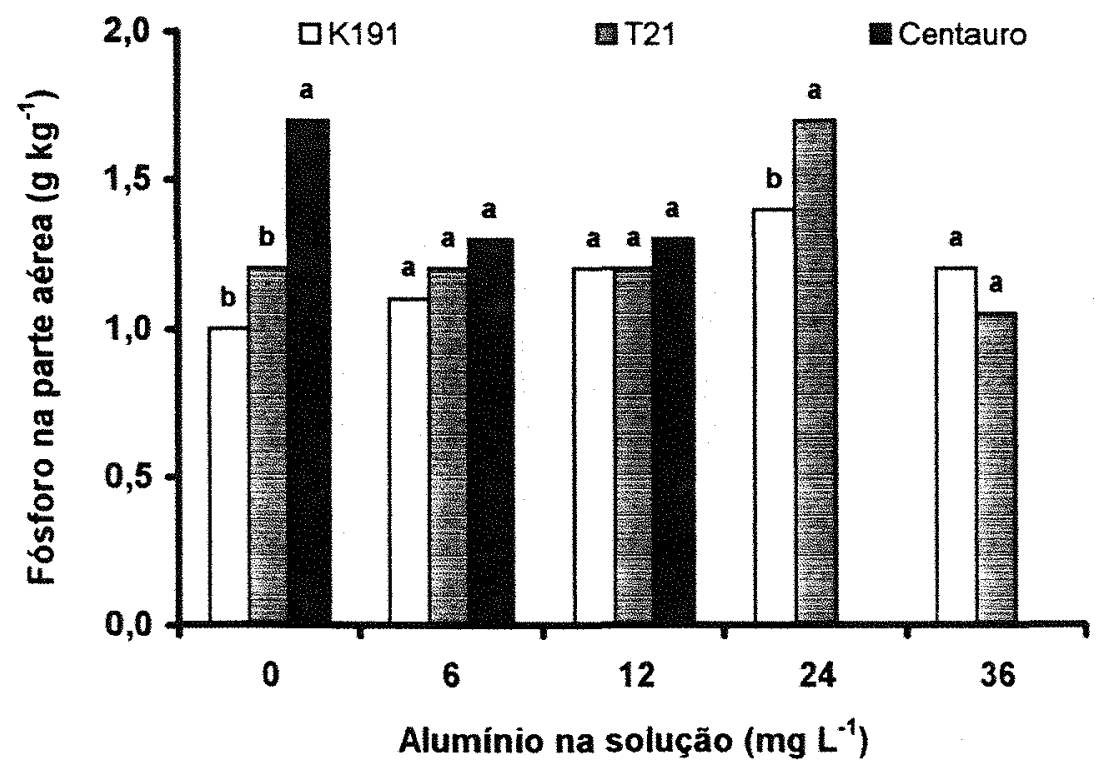

Figura 40 - Concentração de fósforo na parte aérea de três genótipos de Panicum maximum, em função das doses de alumínio na solução nutritiva. (Letras comparam genótipos dentro de cada dose de alumínio pelo teste de Tukey a $5 \%$ ).

$\mathrm{Na}$ dose de alumínio de $24 \mathrm{mg} \mathrm{L}^{-1}$ o genótipo intermediário $\mathrm{T} 21$ mostrou maior concentração de fósforo na parte aérea comparado ao genótipo tolerante K191. Todavia, na mais alta dose de aluminio estes genótipos não mostraram diferenças significativas $(P>0,05)$ na concentração de fósforo na parte aérea das plantas. 
Segundo a análise de regressão, os genótipos K191 e T21 apresentaram ajustes quadráticos na concentração de fósforo, sendo que para o Centauro a concentração de fósforo na parte aérea não sofreu variação com a adição de alumínio (Figura 41). Esses resultados ratificam os resultados de Floss (1992), que também contrariam relatos de que o estresse por alumínio diminui a concentração de fósforo na parte aérea. Nos casos em que essa redução foi reportada ela foi apontada como consequiência da formação de precipitados nas células das raízes (Clarkson, 1966; Clarkson, 1967; Jarvis \& Hatch, 1987).

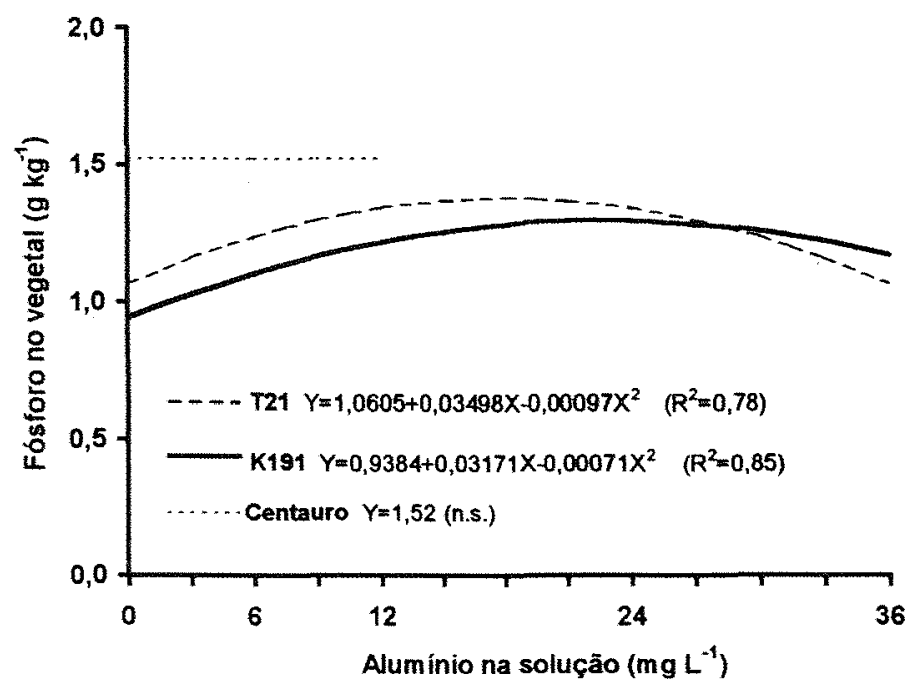

Figura 41 - Concentração de fósforo na parte aérea dos genótipos de Panicum maximum, em função da dose de alumínio na solução nutritiva.

Os resultados para o acúmulo de fósforo na parte aérea mostraram efeitos significativos $(\mathrm{P}<0,05)$ para os genótipos e para as doses de alumínio na solução. $\mathrm{Na}$ média das doses de alumínio, os genótipos não diferiram significativamente pelo teste de Tukey (Figura 42). Foy et al. (1965) verificaram que em plantas de trigo, o cultivar sensível ao excesso de alumínio acumulou menos fósforo na parte aérea do que o cultivar tolerante. Analisando-se as médias apresentadas na Figura 41 nota-se que o cultivar Centauro teve acúmulo de fósforo na parte aérea praticamente equivalente à metade daquela do genótipo K191. 


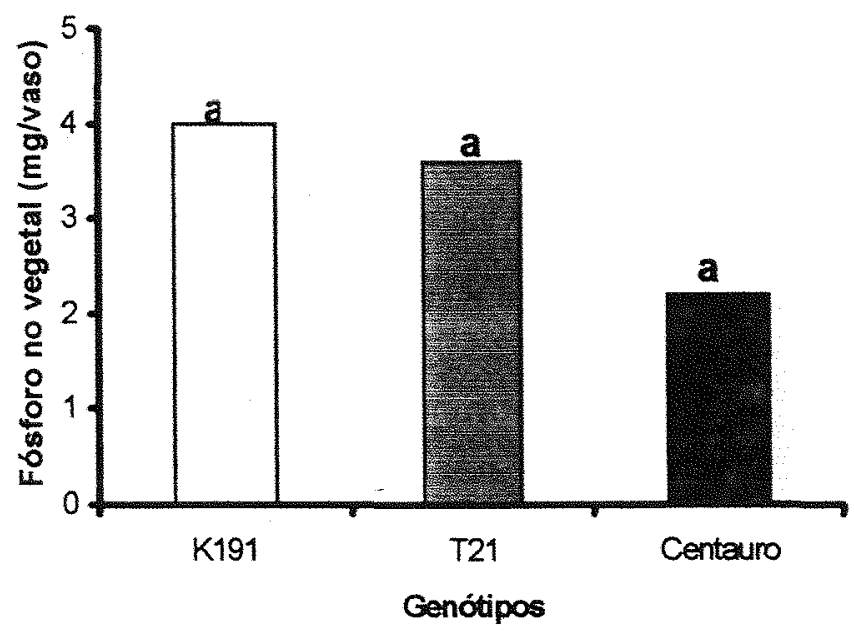

Figura 42 - Acúmulo de fósforo na parte aérea de três genótipos de Panicum maximum, em função das doses de aluminio na solução nutritiva. (Letras comparam genótipos pelo teste de Tukey a $5 \%$ ).

Quanto ao efeito das doses de alumínio, na média dos genótipos, o acúmulo de fósforo na parte aérea foi ajustado a uma equação de segundo grau, com ponto de mínimo em $30 \mathrm{mg}$ de alumínio por litro da solução nutritiva (Figura $43)$.

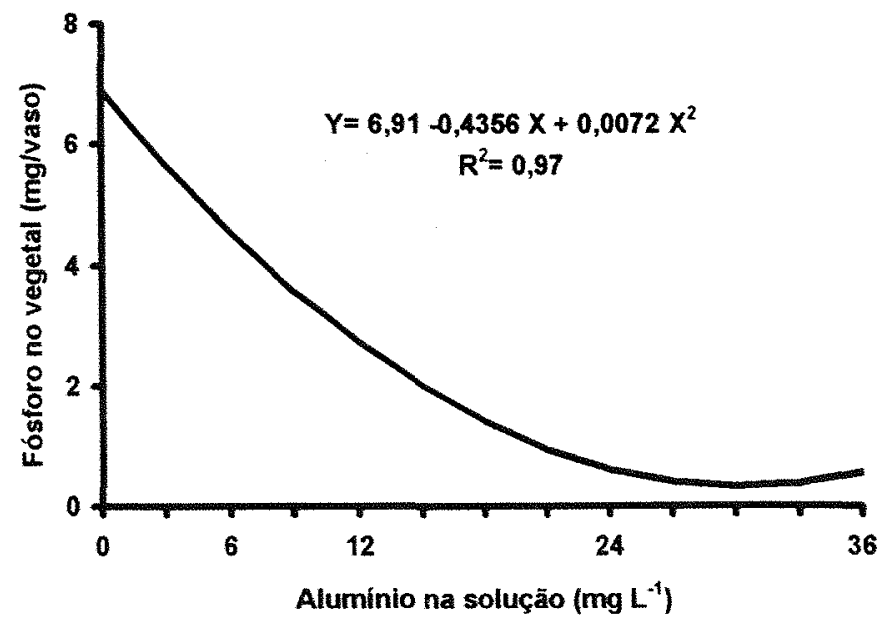

Figura 43 - Acúmulo de fósforo na parte aérea dos genótipos de Panicum maximum, em função da dose de alumínio na solução nutritiva. 
$\mathrm{Na}$ análise de variância para concentração e acúmulo de fósforo nas raízes a interação genótipos $\mathrm{x}$ doses de alumínio não foi significativa $(\mathrm{P}>0,05)$.

Comparando-se as médias dos genótipos, para todas as doses de alumínio, nota-se que o genótipo Centauro apresentou a mais elevada concentração de fósforo nas raízes (Figura 44).

Quanto ao efeito das doses de alumínio, na média dos genótipos, a concentração de fósforo nas raízes foi decrescente em função da elevação da dose de alumínio na solução nutritiva (Figura 45). A redução na concentração de fósforo nas raizes em função da elevação da dose de alumínio foi representada por um modelo linear. Esses resultados contrariam Jarvis \& Hatch (1987), que relataram aumento na concentração de fósforo nas raizes de trevo branco (Trifolium repens) e diminuição na parte aérea, com o incremento do alumínio no substrato.

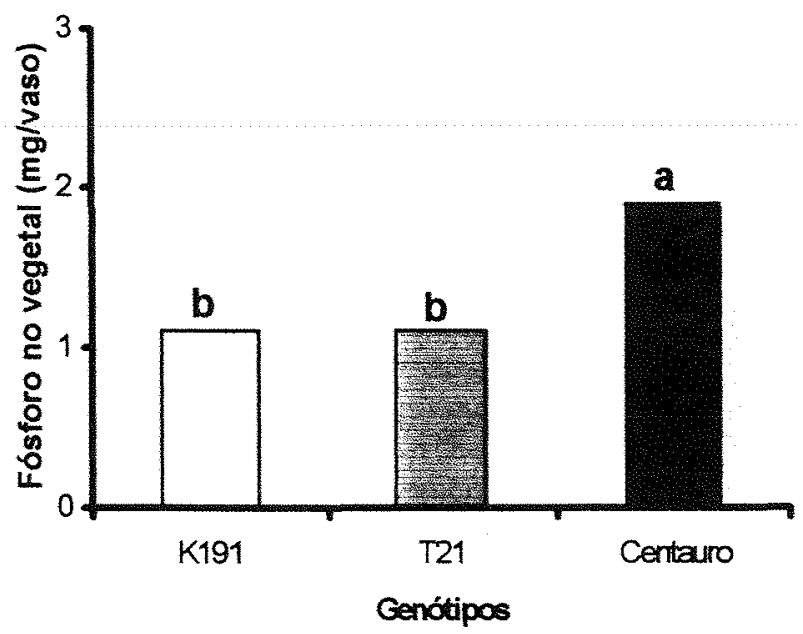

Figura 44 - Concentração de fósforo nas raizes de três genótipos de Panicum maximum, em função das doses de alumínio na solução nutritiva. (Letras comparam genótipos pelo teste de Tukey a $5 \%$ ). 


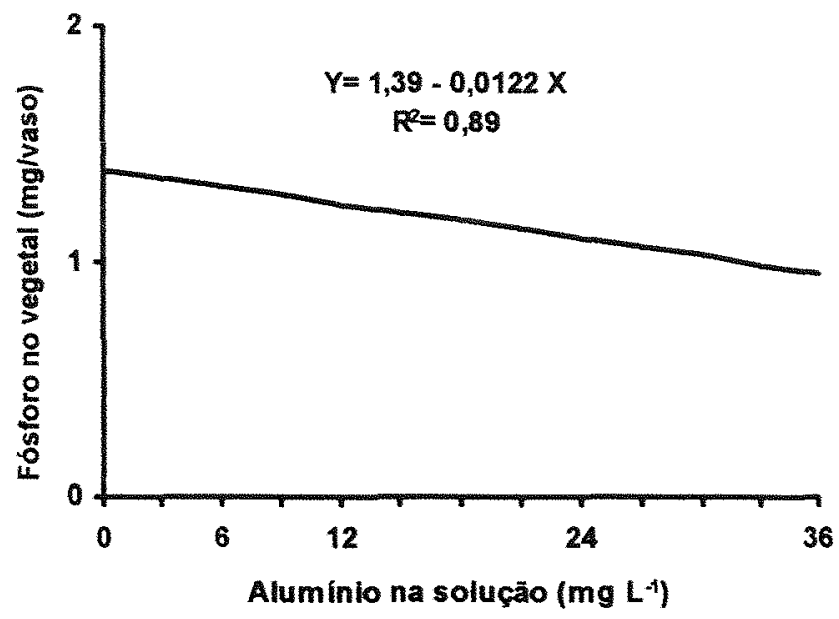

Figura 45 - Concentração de fósforo nas raízes dos genótipos de Panicum maximum, em função da dose de alumínio na solução nutritiva.

Na Figura 46 observa-se que para o acúmulo de fósforo nas raízes, na média das doses de alumínio, o genótipo Centauro acumulou menos fósforo nas raízes do que os capins K191 e T21, em conseqüência da sua menor produção de matéria seca.

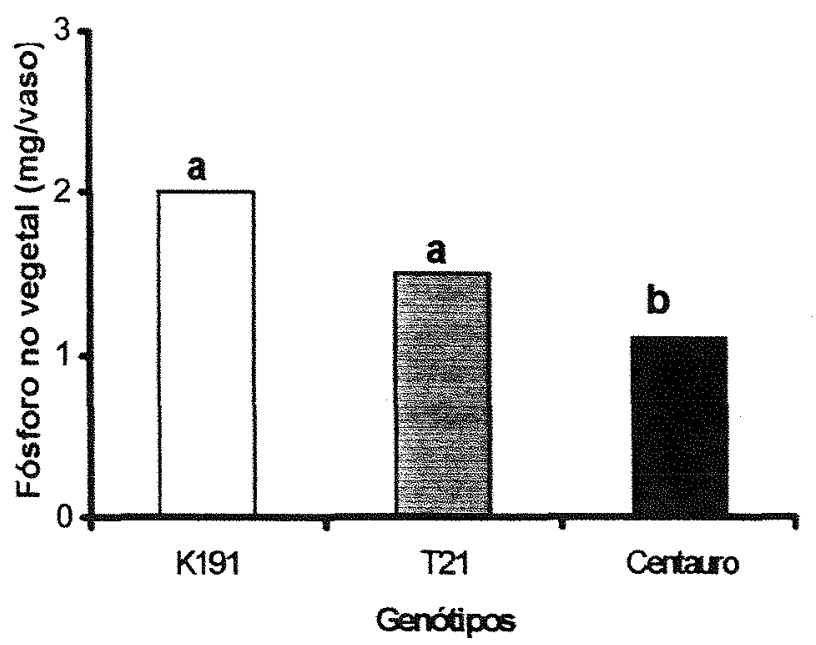

Figura 46 - Acúmulo de fósforo nas raizes de três genótipos de Panicum maximum, em função das doses de alumínio na solução nutritiva. (Letras comparam genótipos pelo teste de Tukey a $5 \%$ ). 
Para o efeito das doses de alumínio, na média dos genótipos, a análise de regressão ajustou uma equação quadrática para o acúmulo de fósforo nas raízes, que teve máxima redução com a adição de $31 \mathrm{mg}$ de $\mathrm{Al} \mathrm{L}^{-1}$ de solução (Figura 47). Estes resultados diferem daqueles referidos por Clarkson (1966 e 1967) de que a concentração de fósforo nas raizes aumenta com o incremento da disponibilidade de alumínio, determinando seu acúmulo nesse órgão.

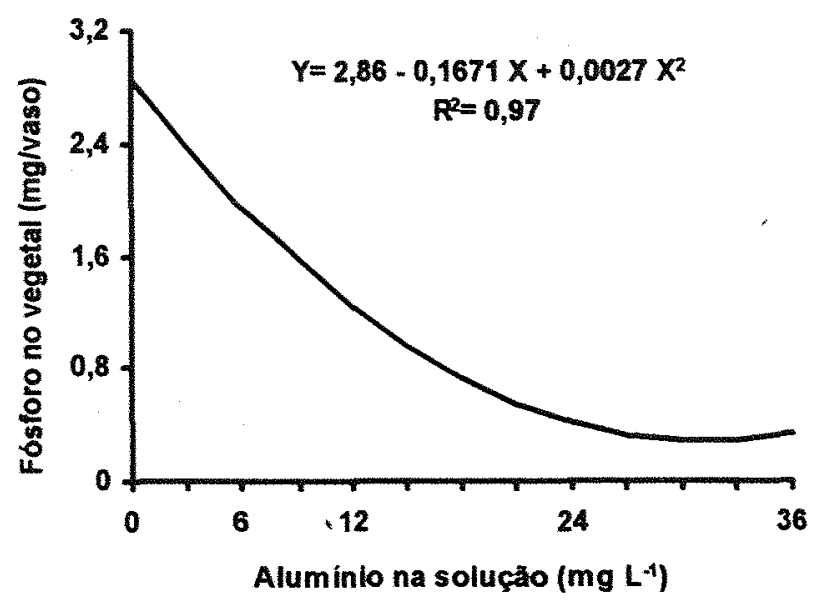

Figura 47 - Acúmulo de fósforo nas raízes dos genótipos de Panicum maximum, em função da dose de alumínio na solução nutritiva.

\subsubsection{Concentração e acúmulo de magnésio}

A análise de variância para a concentração de magnésio na parte aérea, evidenciou efeitos significativos $(\mathrm{P}<0,05)$ para os genótipos e as doses de alumínio na solução e não significativo para a interação genótipos $\mathrm{x}$ doses.

Através da comparação entre médias dos genótipos (Figura 48) observase que a concentração de magnésio na parte aérea dos genótipos T21 e Centauro foram mais baixas que a apresentada pelo K191, genótipo tolerante ao excesso de alumínio. 
Para o efeito das doses de alumínio na média dos genótipos, a concentração de magnésio na parte aérea foi decrescente até o incremento de 34 mg de alumínio na solução nutritiva. Através da análise de regressão polinomial obteve-se uma equação quadrática para representar essa redução (Figura 49). A redução na concentração de magnésio nas plantas cultivadas na presença de alumínio é descrita na literatura. Resultados semelhantes foram descritos para aveia por Floss (1992). Também em aveia, Grimme (1983) referiu que a redução na concentração de magnésio pelo alumínio resulta da inibição da absorção de magnésio pelas raízes. Em leguminosas forrageiras de clima temperado, Wheeler \& Dodd (1995), estudando o efeito do alumínio observaram que a presença do cátion promoveu decréscimos nas concentrações de magnésio.

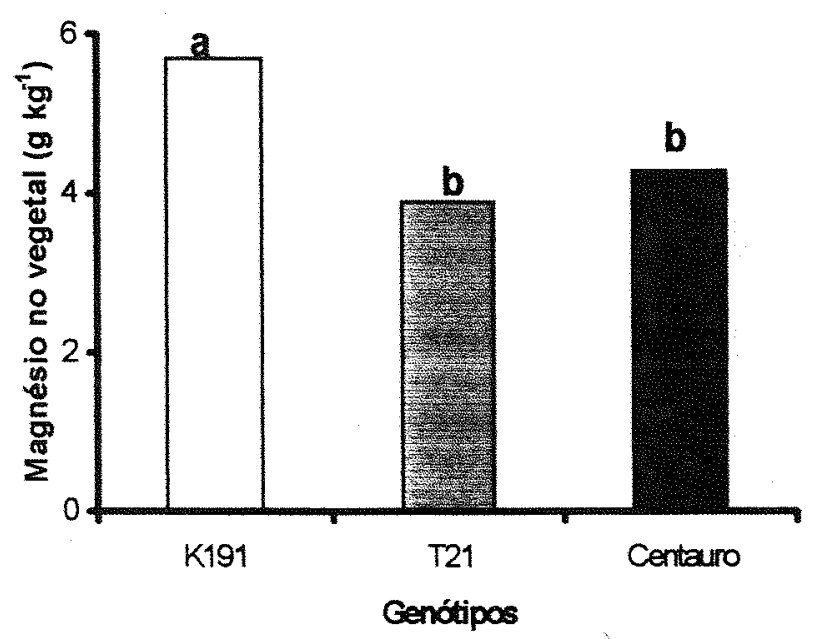

Figura 48- Concentração de magnésio na parte aérea dos três genótipos de Panicum maximum, em função das doses de alumínio na solução nutritiva. (Letras comparam genótipos pelo teste de Tukey a 5\%). 


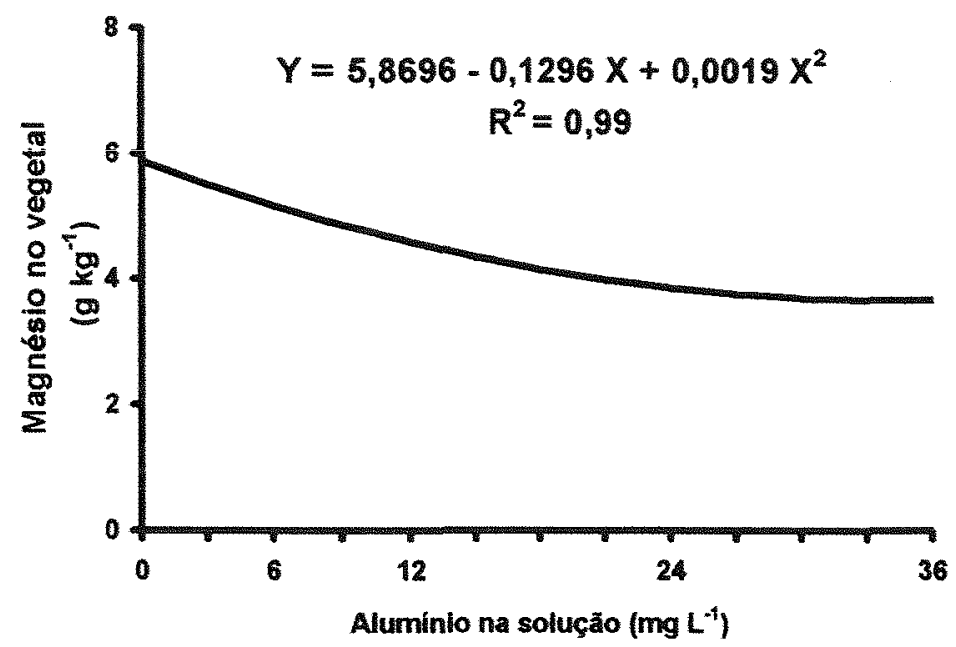

Figura 49 - Concentração de magnésio na parte aérea dos genótipos de Panicum maximum, em função da dose de alumínio na solução nutritiva.

Para a concentração de magnésio nas raízes dos três capins estudados, a análise de variância mostrou que a interação entre genótipos e doses de alumínio foi significativa $(\mathrm{P}<0,05)$.

Através da comparação entre médias dos genótipos, dentro de cada dose de alumínio (Figura 50), observa-se que na omissão de alumínio o cultivar Centauro apresentou mais elevada concentração de magnésio nas raízes que os genótipos K191 e T21. Na presença de alumínio o genótipo T21 sempre mostrou mais alta concentração de magnésio nas raizes que o Centauro. Nas doses de alumínio de 6 e $36 \mathrm{mg} \mathrm{L}^{-1}$ os genótipos K191 e T21 não diferiram entre si, mas nas doses intermediárias de 12 e $24 \mathrm{mg} \mathrm{L}^{-1}$, as plantas de $\mathrm{T} 21$ apresentaram concentração de magnésio mais elevada que as de K191. 


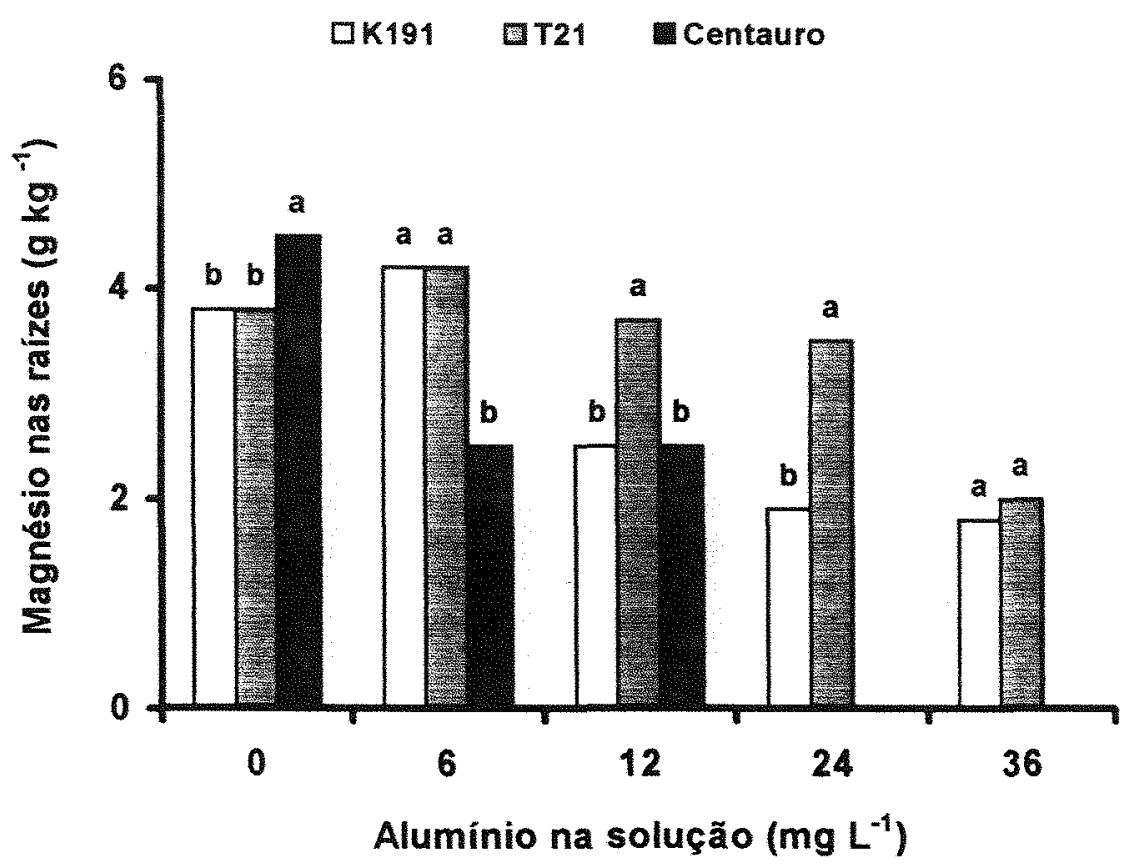

Figura 50 - Concentração de magnésio nas raízes de três genótipos de Panicum maximum, em função das doses de alumínio na solução nutritiva. (Letras comparam genótipos dentro de cada dose de aluminio pelo teste de Tukey a $5 \%$ ).

Para as raizes, o efeito limitante do alumínio na concentração de magnésio foi linear para os genótipos K191 e Centauro. No genótipo T21 a variação nessa concentração foi representada por uma equação de segundo grau (Figura 51). A redução na concentração de magnésio na parte aérea e nas raízes das forrageiras estudadas está de acordo com as observações de Cambraia et al. (1987), Grimme (1983) e Floss (1992). Grimme (1983) relatou que o alumínio no substrato promoveu inibição da absorção de magnésio pelas raízes de aveia. 


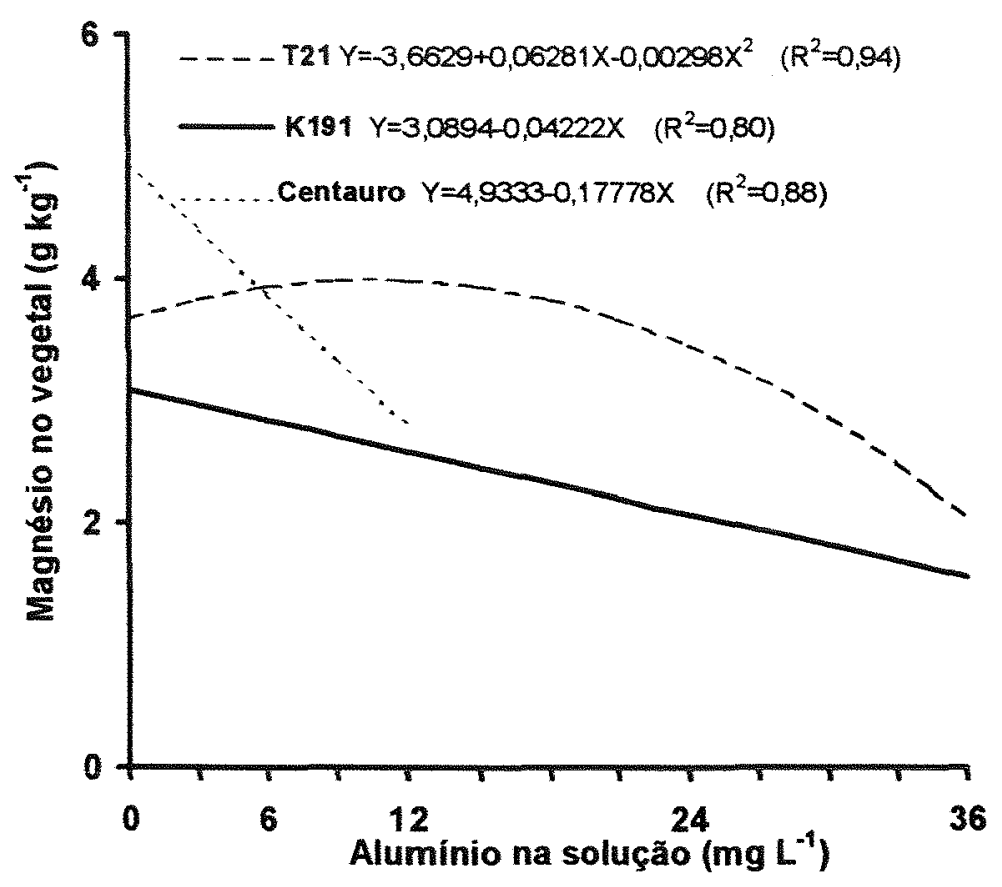

Figura 51 - Concentração de magnésio nas raízes dos genótipos de Panicum maximum, em função das doses de alumínio na solução nutritiva.

$\mathrm{O}$ teste $\mathrm{F}$ detectou significância $(\mathrm{P}<0,01)$ para a interação genótipos $\mathrm{X}$ doses de alumínio no acúmulo de magnésio na parte aérea e nas raízes dos capins.

A partir da comparação entre médias dos genótipos dentro de cada dose de alumínio verifica-se que o Centauro acumulou menos magnésio na parte aérea (Figura 52) e nas raízes (Figura 53) que os capins K191 e T21. O genótipo tolerante K191 mostrou concentração de magnésio na parte aérea mais elevada que $\mathrm{T} 21$ apenas na dose $6 \mathrm{mg}$ de $\mathrm{Al} \mathrm{L}^{-1}$. Com relação às raízes, os genótipos $\mathrm{K} 191$ e T21 não apresentaram diferenças para o acúmulo de magnésio. 


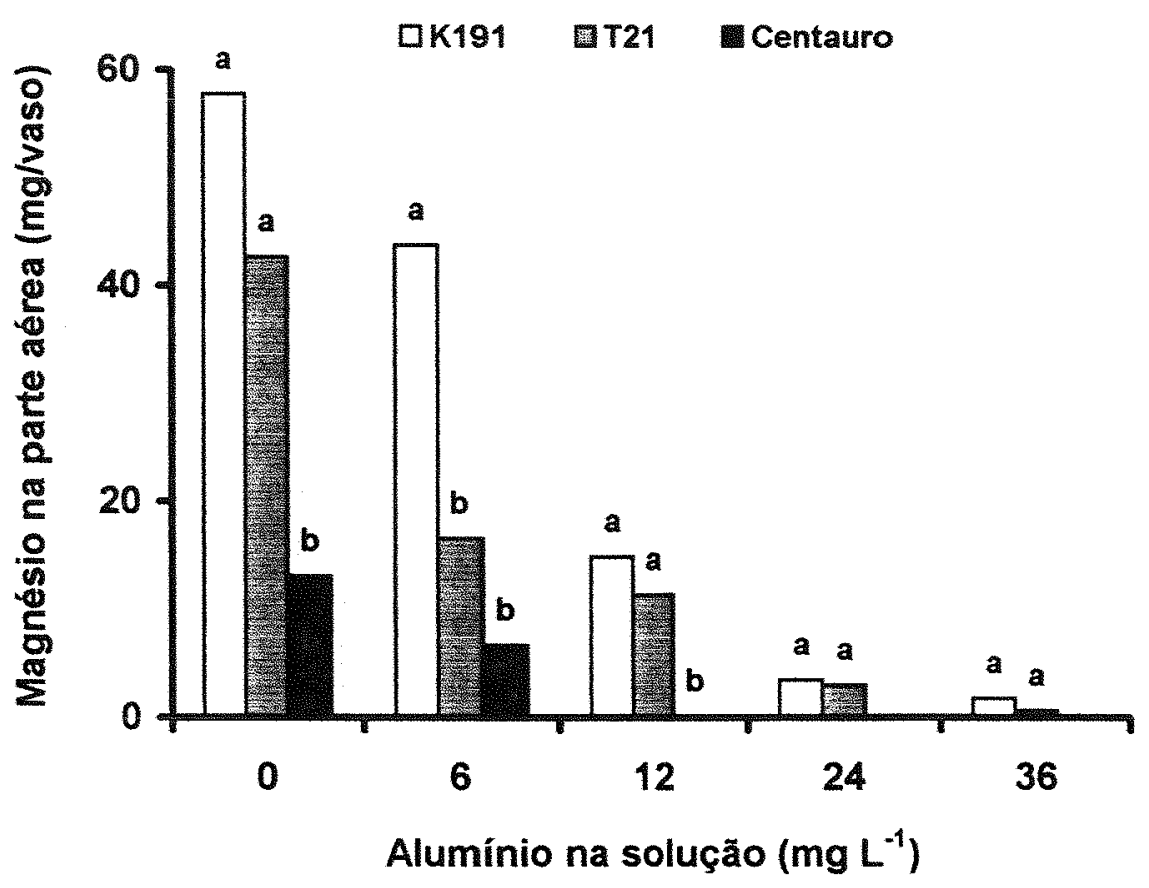

Figura 52- Acúmulo de magnésio na parte aérea dos três genótipos de Panicum maximum, em função das doses de alumínio na solução nutritiva. (Letras comparam genótipos dentro de cada dose de aluminio pelo teste de Tukey a $5 \%$ ).

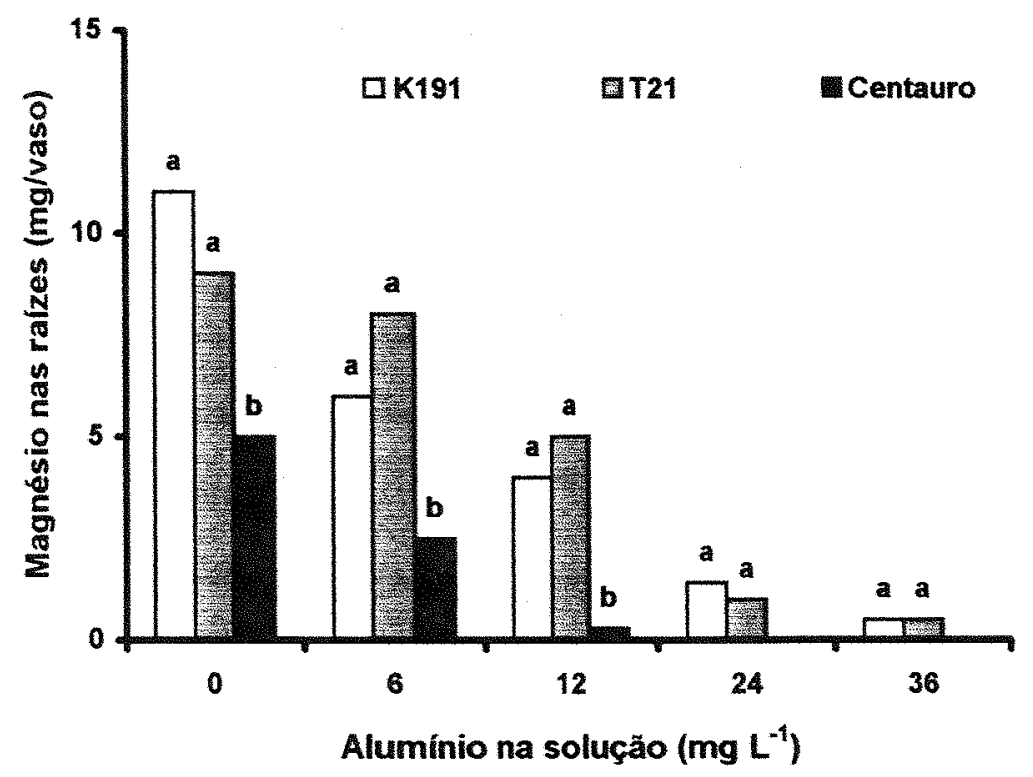

Figura 53 - Acúmulo de magnésio nas raizes dos três genótipos de Panicum maximum, em função das doses de alumínio na solução nutritiva. (Letras comparam genótipos dentro de cada dose de alumínio pelo teste de Tukey a 5\%). 
A adição de alumínio na solução nutritiva promoveu variação no acúmulo de magnésio na parte aérea e nas raizes das forrageiras. A variação no acúmulo de magnésio na parte aérea das plantas estudadas, em função da elevação da dose de alumínio na solução, foi ajustada a modelos quadráticos, com máxima redução no acúmulo de magnésio nas doses de 27 e $29 \mathrm{mg}$ de $\mathrm{Al} \mathrm{L}^{-1}$, para T21 e K191, respectivamente (Figura 54).

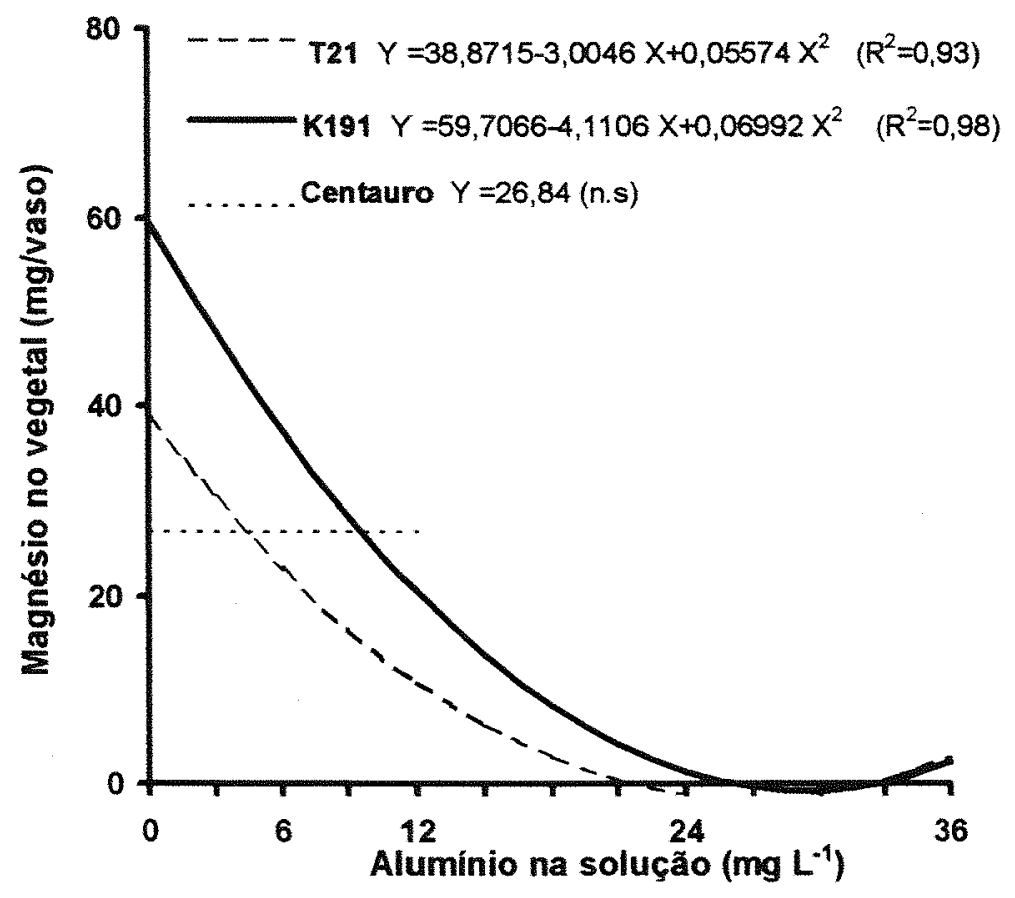

Figura 54 - Acúmulo de magnésio na parte aérea dos genótipos de Panicum maximum, em função das doses de alumínio na solução nutritiva.

Para o acúmulo de magnésio nas raízes os ajustes foram quadráticos para K191 e T21, mínimos em 28 e $42 \mathrm{mg}$ de $\mathrm{Al} \mathrm{L}^{-1}$, respectivamente. Em Centauro o acúmulo de magnésio nas raizes decresceu linearmente (Figura 55). 


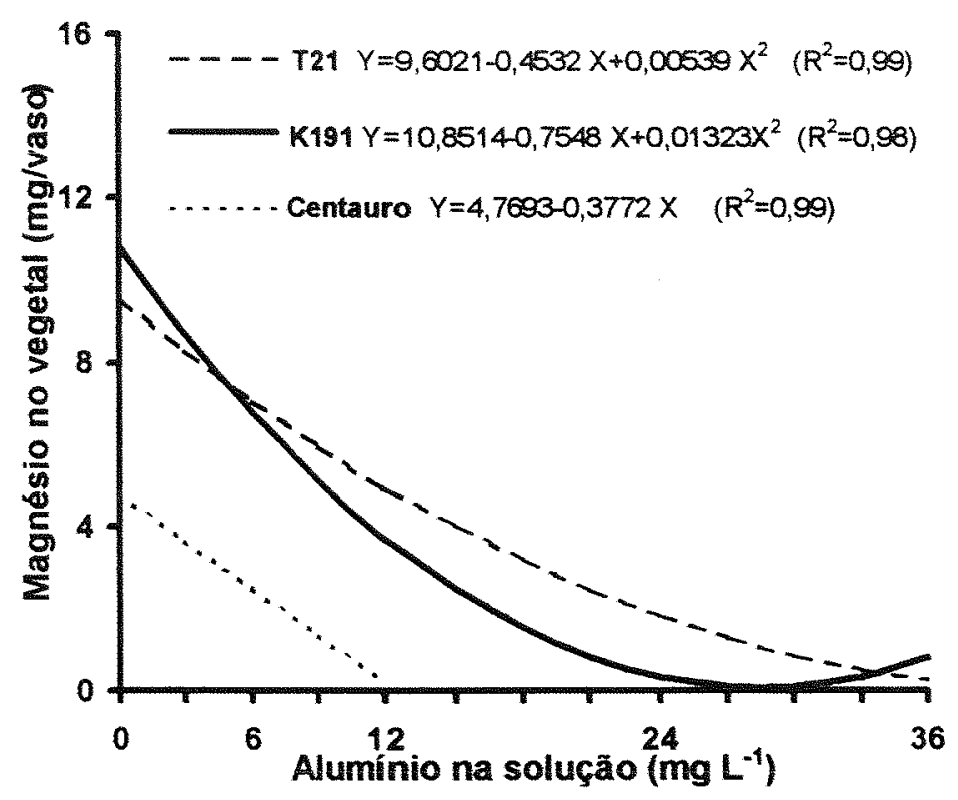

Figura 55 - Acúmulo de magnésio nas raízes dos genótipos de Panicum maximum, em função das doses de alumínio na solução nutritiva.

\subsubsection{Concentração e acúmulo de nitrogênio}

Para a concentração de nitrogênio na parte aérea dos três capins a análise de variância mostrou que a interação entre genótipos e doses de alumínio foi significativa $(P<0,05)$.

A comparação entre os genótipos, dentro de cada dose de alumínio, não evidenciou diferenças entre os capins nas doses de alumínio de 0 ; 6 e $12 \mathrm{mg} \mathrm{L}^{-1}$ de solução. Com a adição de $24 \mathrm{mg}$ de alumínio por litro da solução nutritiva, a concentração de nitrogênio na parte aérea das plantas de T21 foi mais elevada que a das plantas de K191. Entretanto, na dose $36 \mathrm{mg}^{\mathrm{de}} \mathrm{Al} \mathrm{L}^{-1}$ ocorreu o inverso (Figura 56). 


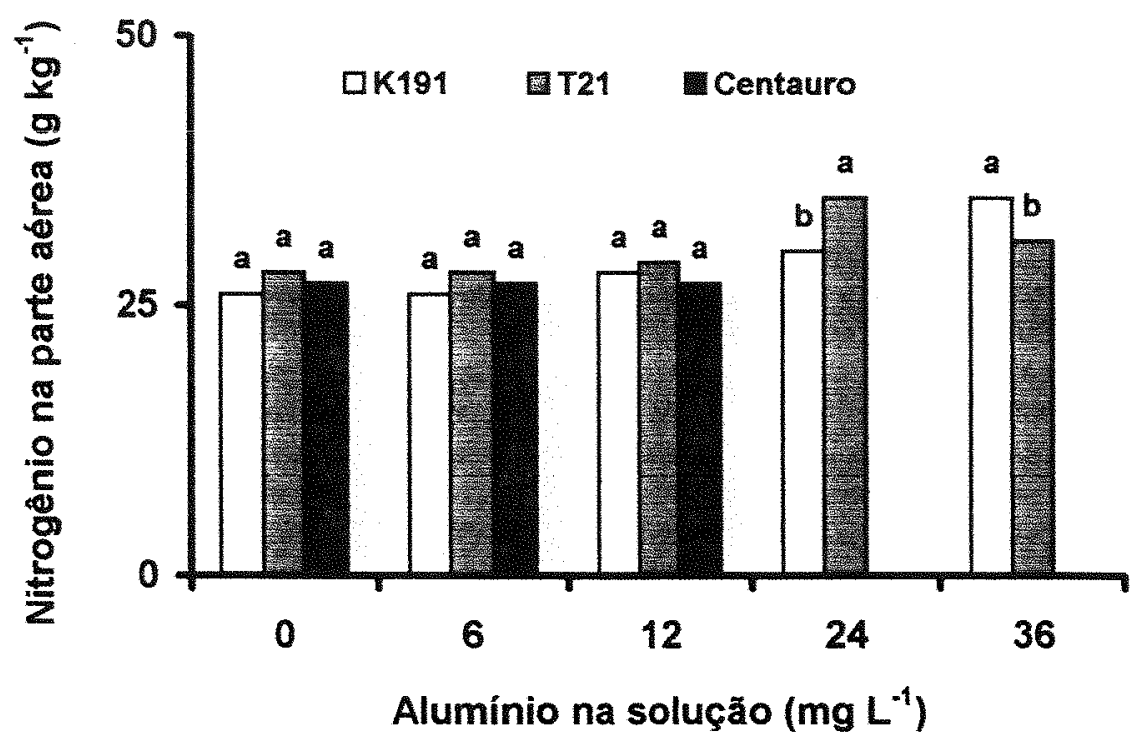

Figura 56- Concentração de nitrogênio na parte aérea de três genótipos de Panicum maximum, em função das doses de alumínio na solução nutritiva. (Letras comparam genótipos dentro de cada dose de alumínio pelo teste de Tukey a 5\%).

Observa-se, na Figura 57, que houve incremento linear na concentração de nitrogênio da parte aérea do genótipo K191 em função da elevação nas doses de alumínio. Para o genótipo T21 a variação nessa concentração seguiu um modelo do segundo grau, com máximo em $26 \mathrm{mg}$ de alumínio por litro de solução. A concentração de nitrogênio na parte aérea do Centauro não foi influenciada significativamente pelo incremento de alumínio em solução.

Para acúmulo nitrogênio na parte aérea dos três capins a análise de variância mostrou que a interação entre genótipos e doses de alumínio foi significativa $(\mathrm{P}<0,05)$. 


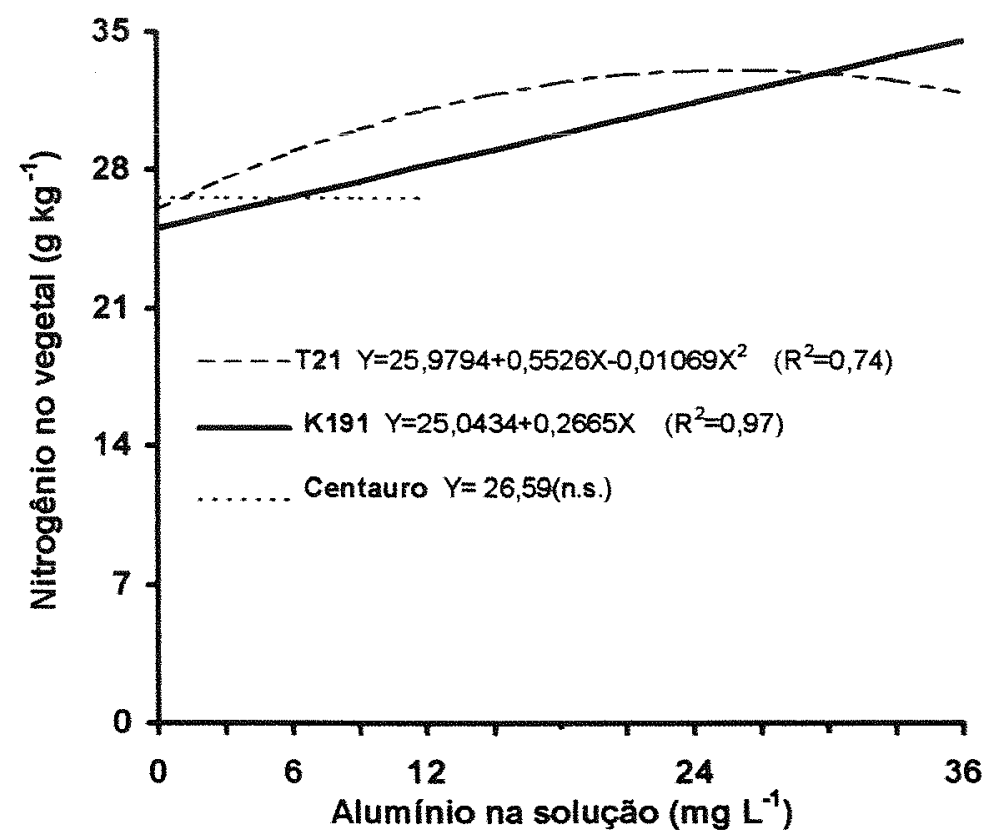

Figura 57 - Concentração de nitrogênio na parte aérea dos genótipos de Panicum maximum, em função das doses de alumínio na solução nutritiva.

$\mathrm{Na} 58$ verifica-se que o acúmulo nitrogênio na parte aérea dos capins foi decrescente segundo um modelo linear o para Centauro. Para os genótipos T21 e K191 os ajustes foram quadráticos, com mínimos em 30 e $32 \mathrm{mg}$ de alumínio da solução. Esse resultado confirma o efeito de concentração do nutriente nos tecidos da parte aérea do vegetal, pois, como visto na Figura 13, o incremento de alumínio promoveu menor rendimento de matéria seca nessa parte da planta .

No tocante ao teor de nitrogênio nas raízes, a análise de variância detectou significância $(\mathrm{P}<0,05)$ para os genótipos e doses de alumínio, não tendo verificado efeito significativo $(P>0,05)$ para a interação entre esses dois fatores. Comparando-se as médias dos genótipos através do teste de Tukey, observa-se que o genótipo Centauro apresentou concentração de nitrogênio nas raizes mais elevada que aquelas dos capins K191 e T21 (Figura 59). 


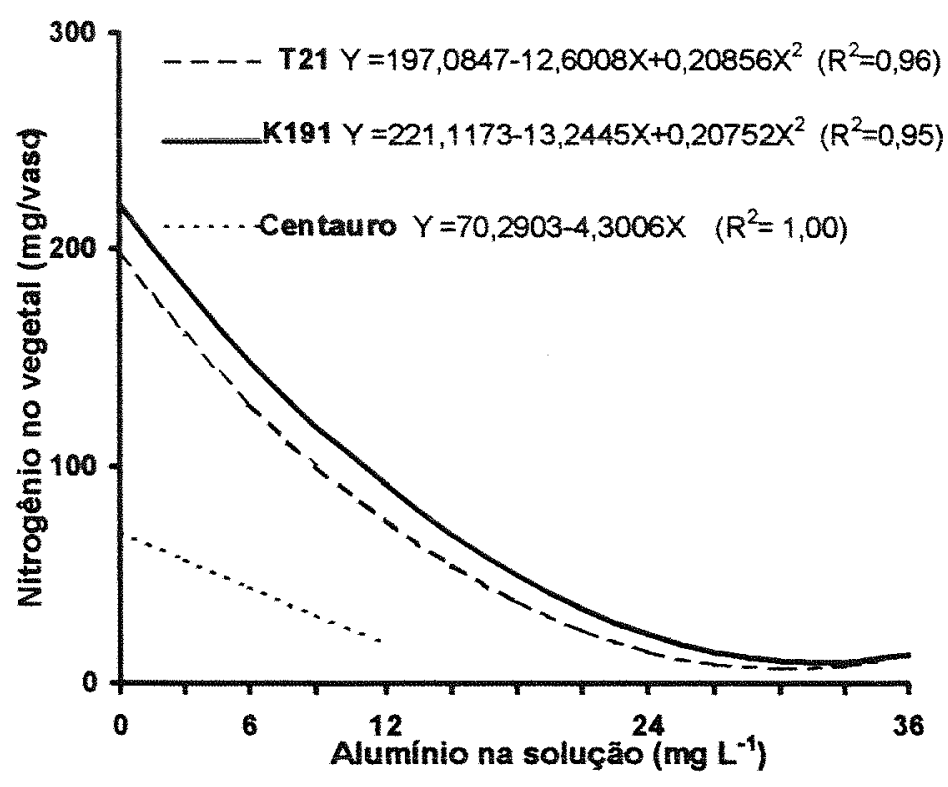

Figura 58- Acúmulo de nitrogênio na parte aérea dos genótipos de Panicum maximum, em função das doses de alumínio na solução nutritiva.

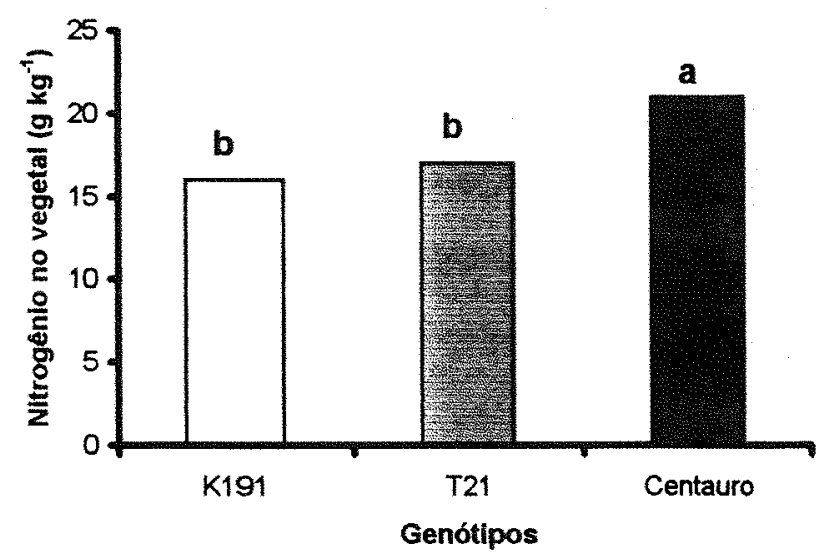

Figura 59 - Concentração de nitrogênio nas raizes de três genótipos de Panicum maximum, em função das doses de alumínio na solução nutritiva. (Letras comparam genótipos pelo teste de Tukey a $5 \%$ ). 
Quanto ao efeito das doses de alumínio, a concentração de nitrogênio nas raízes foi decrescente com o a adição de até $13,7 \mathrm{mg}$ de alumínio da solução nutritiva, sendo representado por um modelo quadrático (Figura 60).

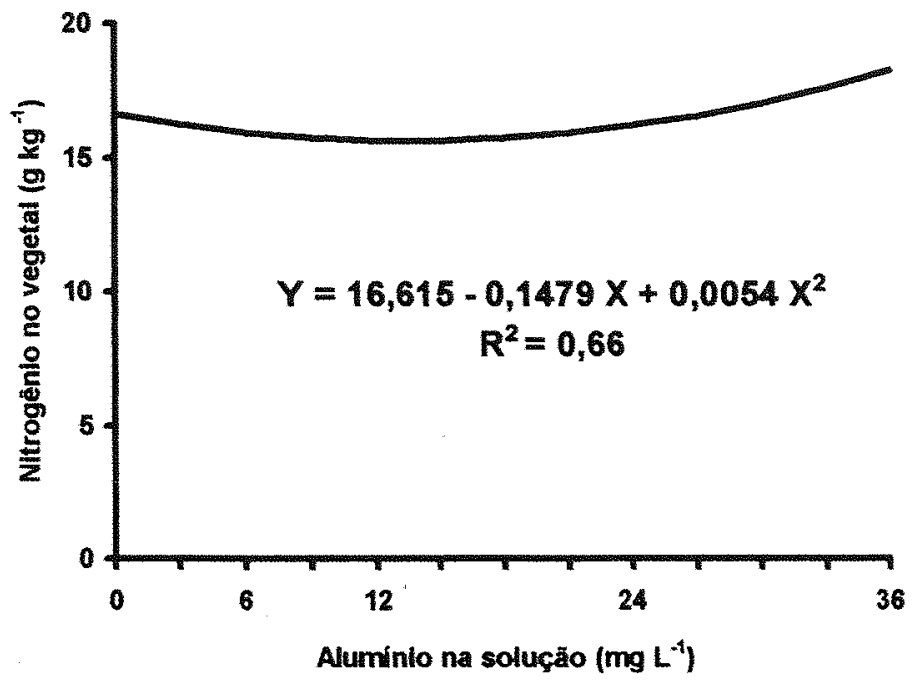

Figura 60- Concentração de nitrogênio nas raízes dos genótipos de Panicum maximum, em função da dose de alumínio na solução nutritiva.

Em relação ao acúmulo de nitrogênio nas raizes, a análise de variância revelou que a interação genótipos $\mathrm{x}$ doses de alumínio não foi significativa $(\mathrm{P}>0,05)$, mas ocorreu significância $(\mathrm{P}<0,05)$ para os fatores doses de alumínio e genótipos.

Na Figura 61 observa-se que para o acúmulo de nitrogênio nas raízes, na média das doses de alumínio, o teste de Tukey não detectou diferenças significativas $(\mathrm{P}>0,05)$ entre os três genótipos de Panicum maximum. Apesar das diferenças mencionadas na produção de matéria seca de raízes, o acúmulo de nitrogênio nos genótipos tolerante e intermediário não foi superior ao do genótipo sensível. 
Para o efeito das doses de alumínio, ilustrado na Figura 62, o acúmulo de nitrogênio nas raizes dos capins foi limitado pela adição de alumínio no meio de crescimento, sendo essa redução representada por uma equação de primeiro grau.

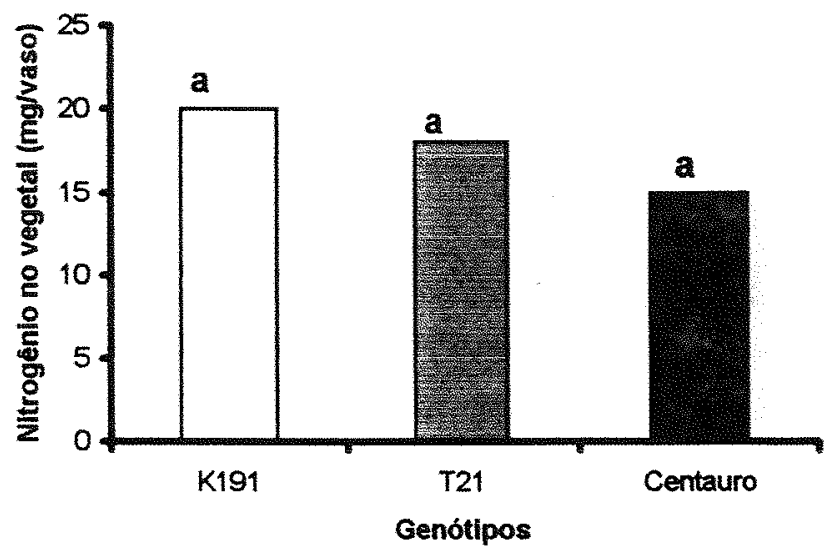

Figura 61 - Acúmulo de nitrogênio nas raizes de três genótipos de Panicum maximum em função das doses de alumínio na solução nutritiva. (Letras comparam genótipos pelo teste de Tukey a $5 \%$ ).

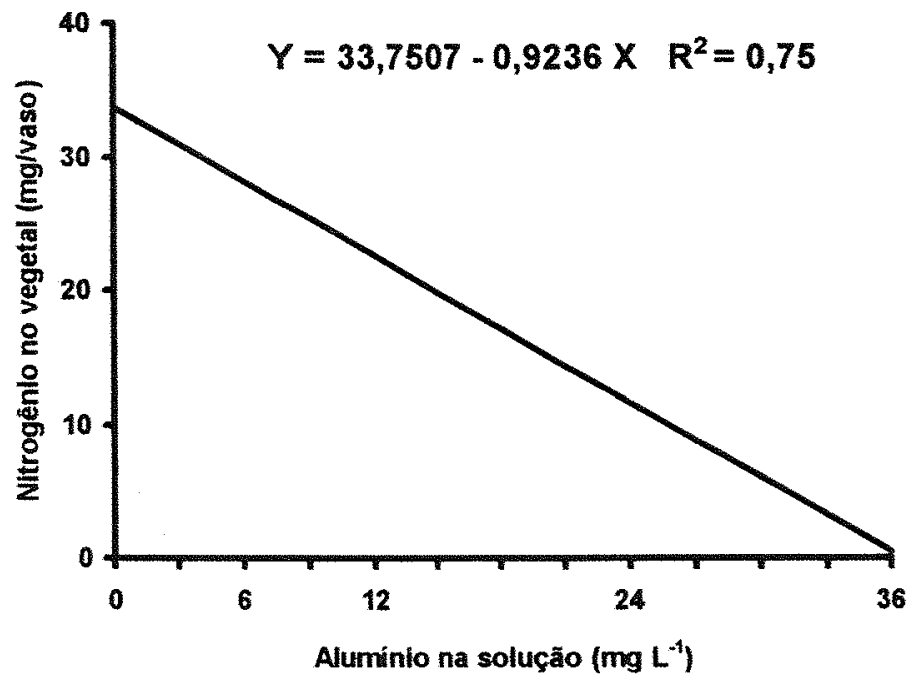

Figura 62- Acúmulo de nitrogênio nas raízes dos genótipos de Panicum maximum, em função da dose de alumínio na solução nutritiva. 


\subsubsection{Concentração e acúmulo de potássio}

De acordo com a análise de variância as concentrações de potássio na parte aérea, bem como nas raízes das plantas, variaram significativamente $(\mathrm{P}<0,05)$ com os genótipos e com as doses de alumínio, não se obtendo significância $(\mathrm{P}>0,05)$ para a interação entre esses dois fatores.

A comparação pelo teste de Tukey mostrou que, na média das doses de alumínio, tanto na parte aérea (Figura 63) quanto nas raizes (Figura 65), o Centauro apresentou maior concentração de potássio que os genótipos K191 e T21.

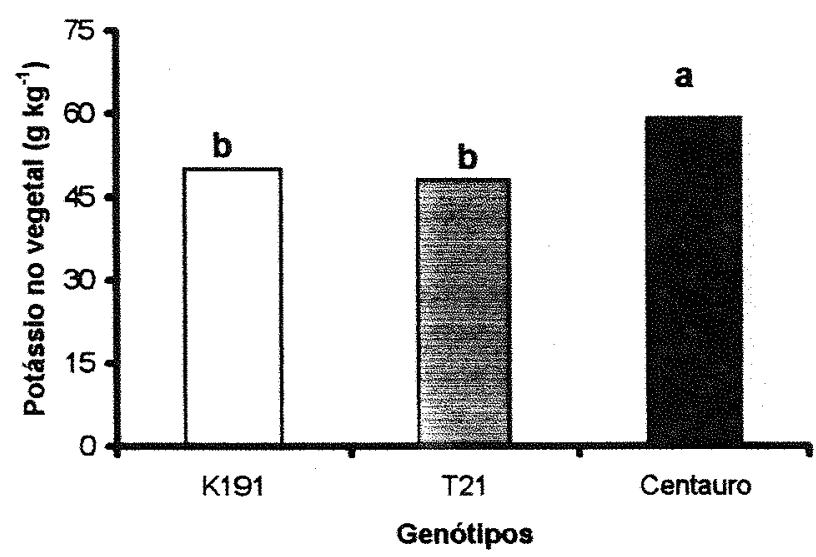

Figura 63 - Concentração de potássio na parte aérea dos três genótipos de Panicum maximum, em função das doses de alumínio na solução nutritiva. (Letras comparam genótipos pelo teste de Tukey a $5 \%$ ).

Quanto ao efeito das doses de alumínio, verifica-se que houve variação na concentração de potássio com o incremento do elemento na solução, tanto na parte aérea (Figura 64) quanto nas raízes (Figura 66) e, em ambos os órgãos, à essa limitação ajustou-se um modelo matemático de segundo grau. A partir da adição de 13 e $11 \mathrm{mg}$ de alumínio por litro da solução nutritiva foram verificadas reduções na concentração de potássio na parte aérea e raízes, respectivamente. 
Essa redução na concentração de potássio com a dose de alumínio provavelmente deve-se a menor absorção de potássio decorrente da competição entre o potássio e o alumínio pelos sítios de absorção das raízes (Petterson \& Strid, 1989).

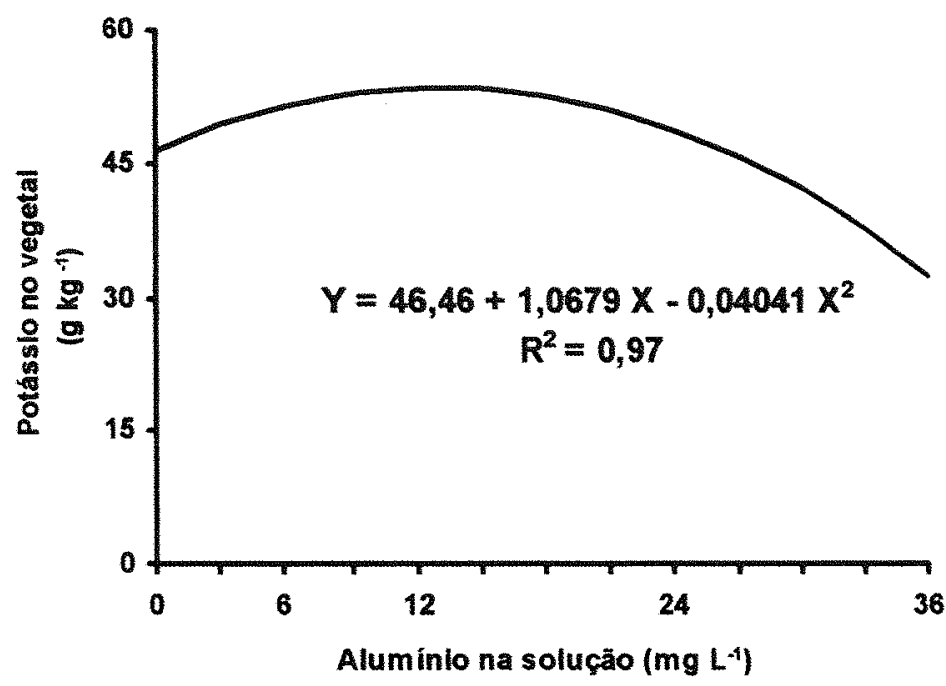

Figura 64 - Concentração de potássio na parte aérea dos genótipos de Panicum maximum, em função da dose de alumínio na solução nutritiva.

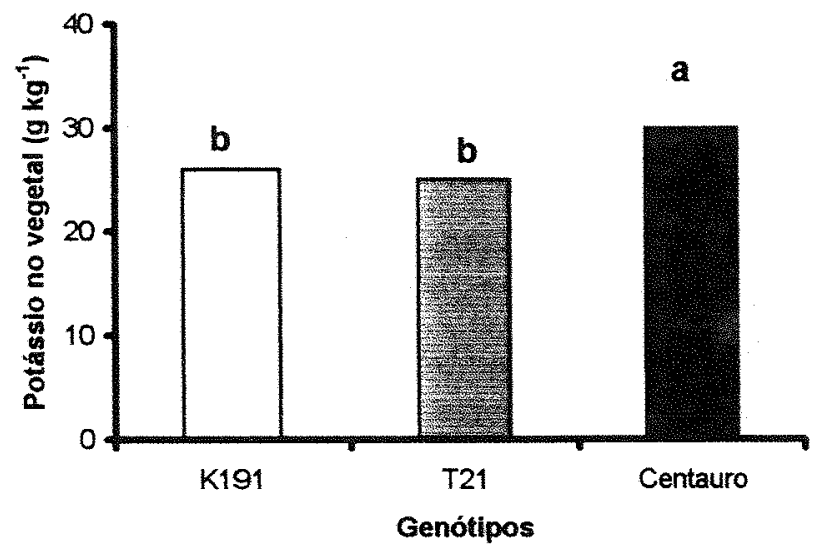

Figura 65 - Concentração de potássio nas raizes de três genótipos de Panicum maximum em função das doses de alumínio na solução nutritiva. (Letras comparam genótipos pelo teste de Tukey a $5 \%$ ). 


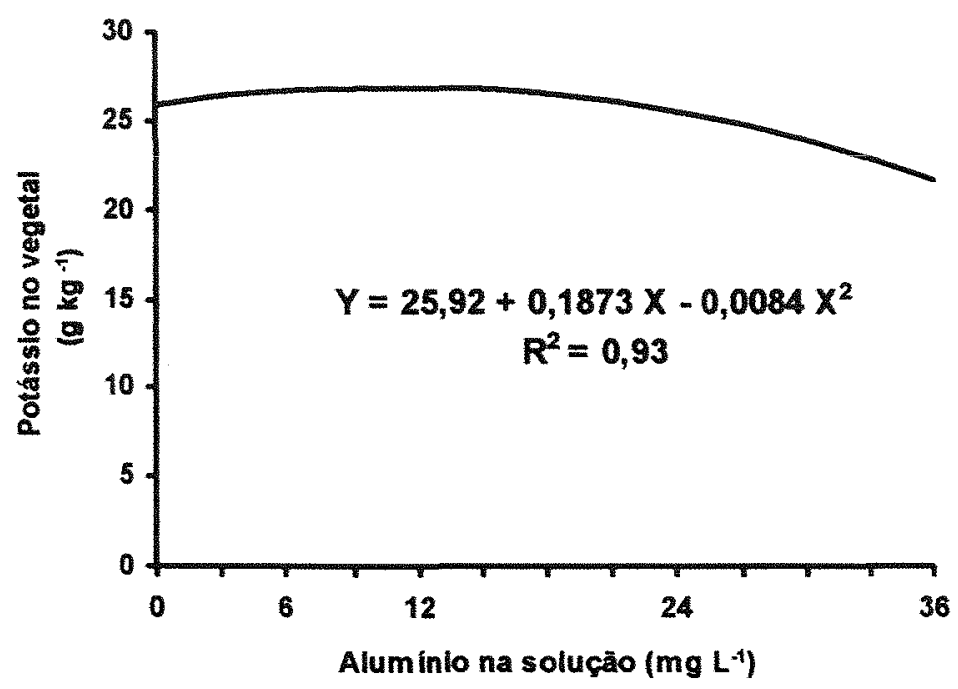

Figura 66 - Concentração de potássio nas raízes dos genótipos de Panicum maximum em função da dose de alumínio na solução nutritiva.

Com relação ao acúmulo de potássio na parte aérea e nas raízes, a análise de variância revelou significância $(P<0,05)$ para os efeitos dos genótipos e das doses de alumínio, não havendo influência significativa $(\mathrm{P}>0,05)$ para a interação entre os dois fatores.

Tanto na parte aérea quanto nas raizes, o genótipo sensível, cultivar Centauro apresentou menor quantidade de potássio acumulada que os outros dois capins (Figuras 67 e 69). Na média das doses, o genótipo K191 não se mostrou significativamente distinto $(\mathrm{P}>0,05)$ do capim- $\mathrm{T} 21$, para o acúmulo de potássio na parte aérea e raizes.

Quanto ao efeito das doses de alumínio, a análise de regressão polinomial ajustou modelos quadráticos para o acúmulo de potássio na parte aérea e raízes decorrente da adição de alumínio na solução nutritiva (Figuras 68 e 70). 


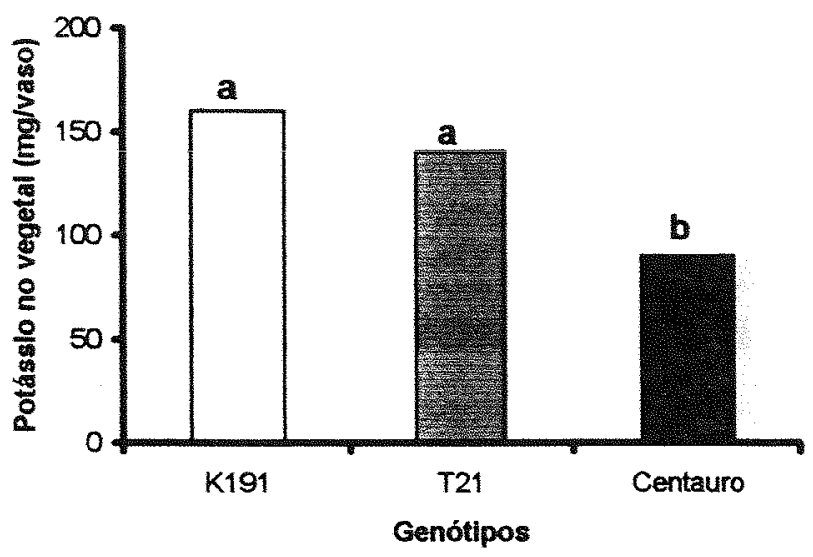

Figura 67 - Acúmulo de potássio na parte aérea dos três genótipos de Panicum maximum, em função das doses de alumínio na solução nutritiva. (Letras comparam genótipos pelo teste de Tukey a 5\%).

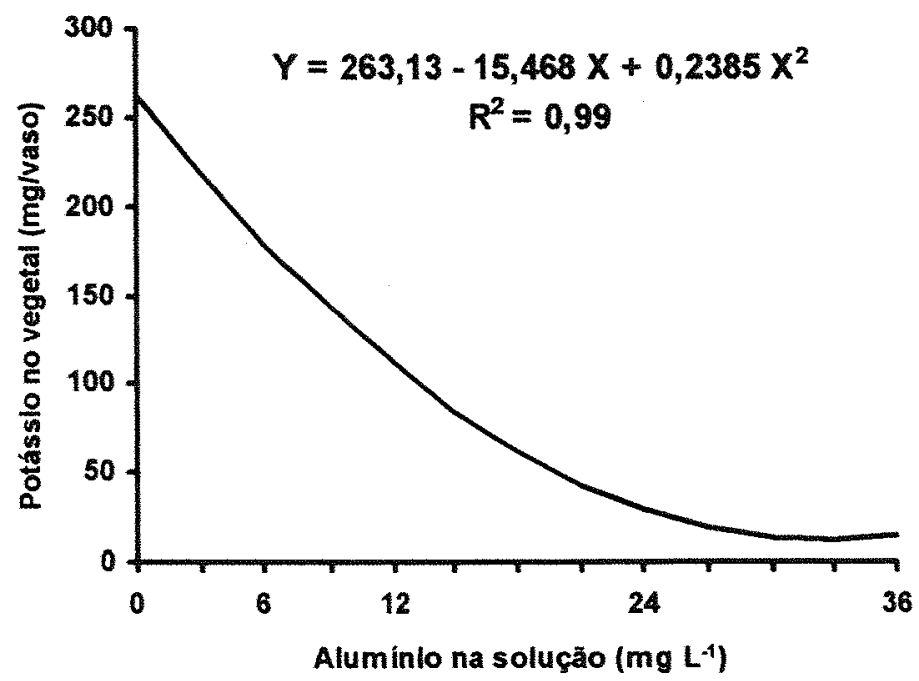

Figura 68 - Acúmulo de potássio na parte aérea dos genótipos de Panicum maximum, em função da dose de alumínio na solução nutritiva. 


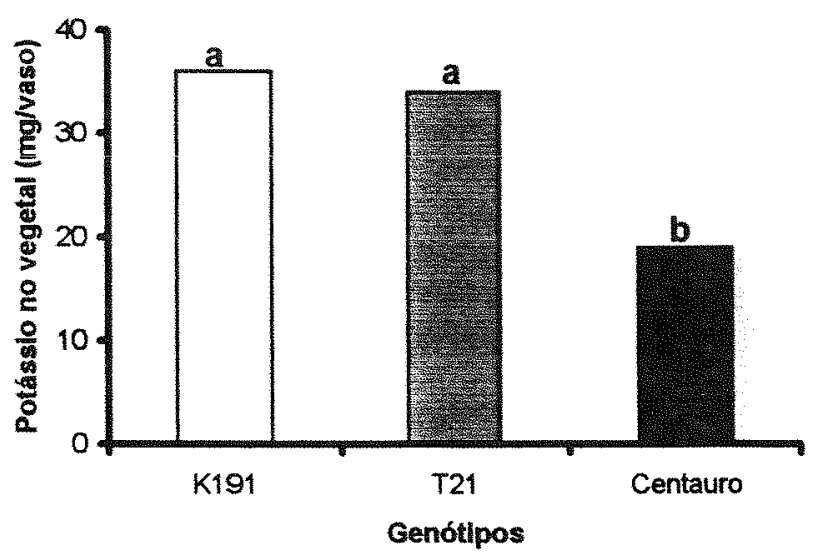

Figura 69 - Acúmulo de potássio nas raízes de três genótipos de Panicum maximum, em função das doses de alumínio na solução nutritiva. (Letras comparam genótipos pelo teste de Tukey a $5 \%$ ).

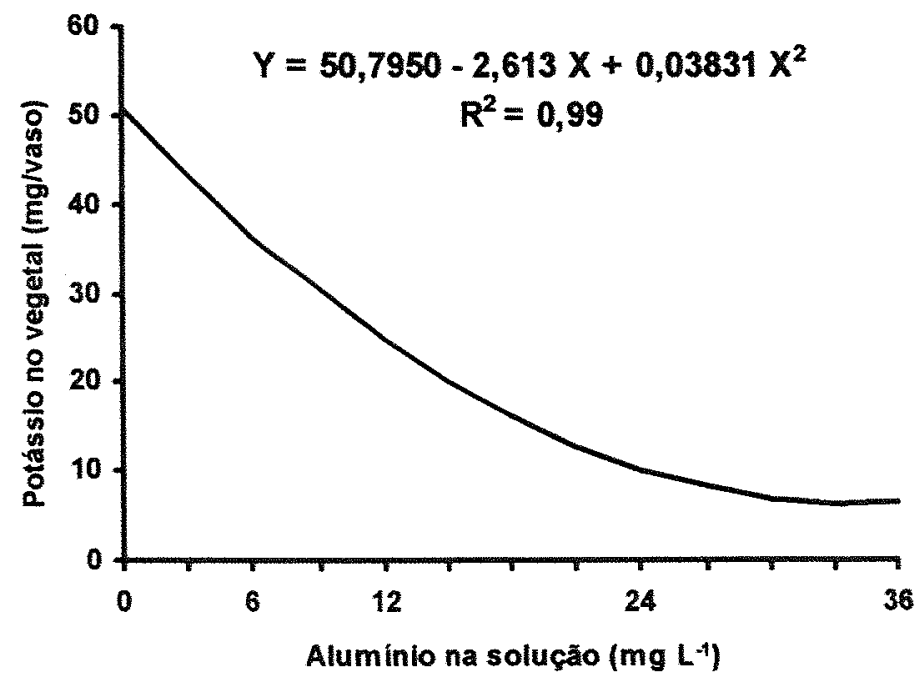

Figura 70- Acúmulo de potássio nas raízes dos genótipos de Panicum maximum, em função da dose de alumínio na solução nutritiva. 
Os resultados apresentados são discordantes em relação aos de Floss (1992) que em aveia verificou aumento na concentração e acúmulo de potássio na planta com a aplicação de doses de alumínio em solução nutritiva. No seu experimento, o autor utilizou como fonte de alumínio o sal duplo de potássio e alumínio $\left(\mathrm{AlK}\left(\mathrm{SO}_{4}\right)_{2} \cdot 12 \mathrm{H}_{2} \mathrm{O}\right)$, o que certamente contribuiu para aumentar a concentração de potássio e enxofre nos órgãos da planta de aveia. No presente estudo tomou-se o cuidado em se utilizar o cloreto de alumínio a fim de se prevenir alterações nas concentrações de outros nutrientes (como o enxofre, no caso mencionado). 


\section{CONCLUSÕES}

A partir dos resultados do presente estudo foi possível concluir que:

há grande variabilidade quanto ao grau de tolerância ao alumínio entre os 30 genótipos de Panicum maximum estudados;

a dose de $24 \mathrm{mg}$ de alumínio por litro da solução nutritiva possibilitou adequada separação do material vegetal quanto à tolerância ao excesso de alumínio;

os genótipos K191, T91, T95, T84 e Centenário destacaram-se como tolerantes ao alumínio;

- os genótipos de moderada tolerância foram T21, K193, T110, K217, K64, KK10, T24, T62, T97, KK8, T60, Mombaça, Vencedor e Tanzânia-1;

- os genótipos sensíveis ao alumínio foram K68, K214, K249, KK33, T46, T72, Colonião, IZ-1, Tobiatã, T77 e Centauro;

- o crescimento dos capins Centauro, T21 e K191 foi severamente limitado pela presença de alumínio em solução;

a atividade da redutase do nitrato foi decrescente com o incremento de alumínio na solução nutritiva, e mais elevada nos genótipos K191 e T21;

a atividade da fosfatase ácida foi crescente com incremento de alumínio na solução nutritiva; 
- as concentrações de cálcio, magnésio e potássio foram reduzidas com a adição de alumínio;

- o alumínio absorvido pelas plantas concentrou-se nas raizes;

- as concentrações de fósforo e nitrogênio aumentaram na parte aérea do vegetal em função do incremento de alumínio na solução; 


\section{REFERÊNCIAS BIBLIOGRÁFICAS}

ADAMS, F. ; LUND, Z.F. Effect of chemical activity of soil solution aluminum on cotton root penetration of and subsoils. Soil Science, v.101, p.193-8, 1966.

ALAM, S.M. Influence of aluminum on plant growth and mineral nutrition of barley. Communications in Soil Science and Plant Analysis, v.12, p.121$38,1981$.

ALAM, S. M.; ADAMS, W.A Effect of aluminum on nutrient composition and yield of oats. Journal of Plant Nutrition, v.1, p.365-375, 1980.

ALCANTÂRA, P.B.; BUFARAH, G. Plantas forrageiras: gramíneas e leguminosas. São Paulo: Nobel, 1979. 150p.

ALVA, A . K.; EDWARDS, D. G.; ASHER, C. J.; BLAMEY, F. P. Relationships between root lenght of soybean and calculated activities of aluminum monomers in nutrient solution. Soil Science Society American Journal, v.50, p.959-962, 1986.

ANDERSON, I.;EVANS, H.J. Effect of manganese and certain other metal cations on isocitric dehydrogenase and malic enzyme activities in Phaseolus vulgaris. Plant Physiology, v.31, p.22-8, 1956.

ANDRADE, L. R. M; IKEDA, M.; ISHIZUKA, J. Stimulation of organic acid excretion by rocts of aluminum-tolerant and aluminum-sensitive wheat varieties under aluminum stress. Revista Brasileira de Fisiologia Vegetal, v. 9, p.27-34, 1997. 
ANDREW, C.S.; JOHNSON, A.D.; SANDLAND, R.L. Effect of aluminum on the growth and chemical composition of some tropical and temperate pasture legumes. Australian Journal of Agricultural Research, v.24, p.325-329, 1973.

ANIOL, A . Genetics of tolerance to aluminum in wheat (Triticum aestivum $\mathrm{L}$. Thell.), Plant and Soil, v.123, p.223-227, 1984.

ARMINGER, W.H.; FOY, C .D.; FLEMING, A . L. Differential tolerance of soybean varieties to an acid high in exchangeable aluminum. Agronomy Journal, v.60, p.67-70, 1968.

ARONOVICH, S. O capim colonião e outros cultivares de Panicum maximum Jacq.: introdução e evolução do uso no Brasil. In: SIMPÓSIO SOBRE MANEJO DA PASTAGEM, 12, Piracicaba. 1995. Anais... Piracicaba: FEALQ, 1995. p.1-20.

ARRUDA, M. L. R.; FERNANDES, M. S.; ROSSIELO, R. O .P. Alumínio e nitrogênio nas variações do $\mathrm{pH}$ e capacidade de troca catiônica em Brachiaria decumbens. Pesquisa Agropecuária Brasileira, v. 18, p.1031-1036, 1983. BALIGAR, V. C.; SCHAFFERT, R.E.; SANTOS, H.L.; PITTA, G. V. E.; BAHIA FILHO, A . F. C. Growth and nutrient uptake parameters in sorghum as influenced by aluminum. Agronomy Journal, v.85, p. 10681074, 1993.

BARCELLOS, A . O . Sistemas extensivos e semi-intensivos de produção: pecuária bovina de corte nos Cerrados. In: SIMPÓSIO SOBRE O CERRADO, 8., 1996, Brasília. Anais... Brasília, 1996. p. 130-136.

BARTLETT, R.J., RIEGO, D.C. Toxicity of hidroxy aluminum in relation to $\mathrm{pH}$ and phosphorus. Soil Science, v.114, p.194-200, 1972. 
BASSO, L. C.; SILVA, F. C. Avaliação da atividade "in vivo" da fosfatase ácida da folha na diagnose da nutrição fosfórica em cana-de-açúcar (Saccharum spp.). In: REUNIÃO BRASILEIRA DE FERTILIDADE DO SOLO E NUTRIÇÃO DE PLANTAS, 20, Piracicaba, 1992. Anais...Piracicaba-SP, Sociedade Brasileira de Ciência do Solo, 1992. p.152-153.

BASU, A .; BASU, U.; TAYLOR, G. J. Induction of microssomal membrane proteins in roots of an aluminum-resistant cultivar of Triticum aestivum $\mathrm{L}$. under conditions of aluminum stress. Plant Physiology, v.104, p.10071013, 1994.

BEEVERS, L.; HAGEMAN, R.H. Nitrate reduction in higher plants. Annual Review of Plant Physiology, v.20, p.495-522, 1969.

BENNET, R. J.; BREEN, C. M. The aluminum signal: new dimensions to mechanism of aluminum tolerance. In: WRIGHT, R. J. (Ed) Plant-Soil Interactions at Low pH. Dordrecht: Kluwer Academic Publishing, 1991. p.703-716.

BEN ZIONI, A ; VAADIA, Y.; HERMAN LIPS, S. Nitrate uptake by roots as regulated by nitrate reduction products of the shoot. Physiologia Plantarum, v.24, p. 288-290, 1971.

BERTON, R.S. Especiação iônica da solução do solo: metodologia e aplicações. In: SIMPÓSIO AVANÇADO DE SOLOS E NUTRIÇÃO DE PLANTAS, 2., Piracicaba, 1989. Anais... Campinas: Fundação Cargill, 1989. p.17-41. BILSKI, J.J.; FOY, C.D. Differential tolerances of oats cultivars to aluminum in nutrient solutions and in acid soils of Paland. Journal of Plant Nutrition, v.10, p.129-41, 1987.

BLAMEY. F.P.C.; EDWARDS, D.G.; ASHER, C.J. Effects of aluminum, OH:Al and molar ratios, and ionic strenght on soybean root elongation in solution culture. Soil Science, v.136, p.197-207, 1983. 
BLAMEY. F.P.C.; ASHER, C.J.; KERVEN, G. L.; EDWARDS, D.G. Factors affecting aluminum sorption by calcium pectate. Plant and Soil, v.149, p.87-94, 1993.

BRAUNER, J.L.; SARRUGE, J.R. Tolerância de cultivares de trigo (Triticum aestivum L.) ao alumínio e ao manganês. III. Influência do alumínio e do grau de tolerância ao alumínio sobre as concentrações de $\mathrm{P}, \mathrm{Ca}$ e $\mathrm{Mg}$ das partes aéreas. Anais da Escola Superior de Agricultura "Luiz de Queiroz", v.37, p.837-48, 1980.

CALBO, A.G.; CAMBRAIA. J. Efeito do alumínio sobre a absorção e transporte de fósforo em dois cultivares de sorgo (Sorghum bicolor L. Moench.). Revista Ceres, v.27, p.615-25, 1980.

CAMARGO, C.E.O. Efeito da temperatura da solução nutritiva na tolerância ao alumínio em cultivares de trigo. Bragantia, v.42, p.51-63, 1983.

CAMARGO, C.E.O. Tolerância de cultivares de arroz a dois níveis de alumínio em soluções nutritivas contendo diferentes concentrações de sais. Bragantia, v.43, p.381-8, 1984.

CAMARGO, C.E.O.; OLIVEIRA, O.F.; LAVORENTI, A. Efeito de diferentes concentrações de sais em solução nutritiva na tolerância de cultivares de trigo à toxicidade de alumínio. Bragantia, v 40, p.93-101, 1981.

CAMARGO, C.E.O.; CAMARGO, O.B.A.; SOUZA, D.M. Diferentes concentrações de alumínio em solução nutritiva, na tolerância de cultivares de arroz. Bragantia, v.43, p.357-68, 1984.

CAMARGO, O . A .; FURLANI, P. R. Alumínio no solo: concentração, especiação e efeito no desenvolvimento radicular. In: SIMPÓSIO AVANÇADO DE SOLOS E NUTRIÇÃO DE PLANTAS, 2., Piracicaba, 1989. Anais... Campinas: Fundação Cargill, 1989. p.45-69. 
CAMBRAIA, J. Mecanismos de tolerância a toxidez de alumínio em plantas. In: REUNIÃO BRASILEIRA DE FISIOLOGIA VEGETAL, 2, Piracicaba, 1989. Anais...Piracicaba, SBFV/ESALQ, 1989. p.85-92.

CAMBRAIA, J.; GALVANI, F.R.; ESTEVÃO, M.M.; et al. Effects of aluminum on organic acid, sugar and amino acid composition of the root system of sorghum. Journal of Plant Nutrition, v.6, p.313-22, 1983.

CAMBRAIA, J.; CHANDIAS, J.E.T.; ESTEVÃO, M.M.; SANTANA, R. Efeito do alumínio sobre o balanço iônico e sobre a capacidade das plantas de sorgo para modificar o pH das soluções nutritivas. Revista Ceres, v.34, p.284-292, 1987.

CAMBRAIA, J.; PIMENTA, J.A.; ESTEVÃO, M.M.; SANTANA, R. Aluminum effects on nitrate uptake and reduction in sorghum. Journal of Plant Nutrition, v.12, p.1435-45, 1989.

CARRIEL, J.M.; PEDREIRA, J.V.S.; MATTOS, H.B. Estimativa da ocorrência dos principais capins no Estado de São Paulo. Zootecnia, v.17, p.5-25, 1979. CARVER, B. F.; OWNBY, J. O . Acid Soil tolerance in wheat. Advances in Agronomy, v.54, p.117-174, 1995.

CLARK, R.B. Characterization of phosphatase of intact maize roots. Journal of Agricultural and Food Chemistry, v.23, p.458-60, 1975.

CLARK, R.B. \& BROWN, J.C. Differential phosphorus uptake by phosphorusstressed corn inbreds. Crop Science, v.14, p.505-8, 1974.

CLARK, R. B; GOURLEY, L. M. Mineral element concentrations of sorghum genotypes grown on tropical acid soil. Communication of Soil Science and Plant Analysis, v.19, p.1019-1029, 1988. 
CLARK, R. B; FLORES, C.I.; GOURLEY, L. M. Mineral element concentrations in acid soil tolerant and susceptible sorghum genotypes. Communication of Soil Science and Plant Analysis, v.19, p.1003-1017, 1988.

CLARKSON, D.T. The effect of aluminum and other trivalent metal cations on cell division in root apices of Allium cepa. Annals of Botany, v.29, v.2, p.309-15, 1965.

CLARKSON, D.T. Effect of aluminum on the uptake and metabolism of phosphorus by barley seedlings. Plant Physiology, v.41, p.165-72, 1966.

CLARKSON, D.T. Interactions between aluminum and phosphorus on root surfaces and cell wall materials. Plant and Soil, v.27, p.347-56, 1967.

CONTIBRASIL - Informe Técnico, 2 - outubro, 1985. 4p.

CORSI, M. Exigências nutricionais de plantas forrageiras em pastagens. In: PEIXOTO, A M. ; MOURA, J.C.; FARIA, V.P. (ED.). Pastagens: fundamentos da exploração racional. Piracicaba: FEALQ, 1994. p. 49-64.

CORSI, M. Manejo de plantas forrageiras do gênero Panicum. In: PEIXOTO, A M. ; MOURA, J.C.; FARIA, V.P. (ED.) SIMPÓSIO SOBRE MANEJO DA PASTAGEM, 9, Piracicaba, 1988. Plantas forrageiras de pastagens. Piracicaba: FEALQ, 1995. p. 17-35.

DELHAIZE, E.; RYAN, P.R. Aluminum toxicity and tolerance in plants. Plant Physiology, v. 107, p. 315-321, 1995.

DELHAIZE, E.; RYAN, P.R .; RANDALL, P.J. Aluminum tolerance in wheat (Triticum aestivum L.) II. Aluminum-stimulated excretion of malic acid from root apices. Plant Physiology, v.103, p. 695-702, 1993.

DIAS FILHO, M. B. Espécies forrageiras e estabelecimento de pastagens na amazônia. Belém: EMBRAPA, CPATU, 1987. 49 p. (Documento, 46). 
DINEV, N.; STANCHEVA, I. Changes in nitrate reductase activity, plastid pigment content, and plant mineral composition of wheat, rye, and triticale grown in the presence of aluminum. Journal of Plant Nutrition, v.16, p.2397-2409, 1993.

EMPRESA BRASILEIRA DE PESQUISA AGROPECUÁRIA. Centro de Pesquisa Agropecuária dos Cerrados. Capim Vencedor: nova opção para a formação de pastagens nos cerrados. Planaltina, 1990. n.p.

EVANS, D.K. The effect of sulphate on aluminum concentrations in natural waters. Geochimica et Cosmochimica Acta, v. 46, p. 681-692, 1988.

FAGERIA, N.K. Tolerância diferencial de cultivares de arroz ao alumínio em solução nutritiva. Pesquisa Agropecuária Brasileira, v.171, p.1-9, 1982.

FAGERIA, N.K.; CARVALHO, J.R.P. Influence of aluminum in nutrient solutions on chemical composition in upland rice cultivars. Plant and Soil, v.69, p.31-44, 1982.

FAHL, J.J.; CARELLI, M.L.C.; DEUBER, R. et al. Influência do alumínio no crescimento e na nutrição mineral de cultivares de arroz. Revista Brasileira de Ciência do Solo, v.6, p.203-8, 1982.

FERNANDES, M. S.; ROSSIELO, R. O ; ARRUDA, M. L. R. Relações entre capacidade de troca de cátions das raízes e toxidez de alumínio em duas gramíneas. Pesquisa Agropecuária Brasileira, v.19, p. 631-637,1984.

FLEMING, A.L. Ammonium uptake by wheat. Agronomy Journal, v.75, p.726$30,1983$.

FLOSS, E. L. Avaliação da toxicidade do alumínio em genótipos de aveia. Piracicaba, 1992, 258p. Tese (Doutorado) - Escola Superior de Agricultura "Luiz de Queiroz", Universidade de São Paulo. 
FOY, C.D. Effects of aluminum on plant growth. In: CARSON, E. W. (Ed.) The plant root and its environment. Charlottesville:Univ. Press of Virginia, 1974. p.601-642.

FOY, C.D. General principles involved in screening plants for aluminum and manganese tolerance. In: WRIGHT, M.J.; FERRARI, S.A (ED.) WORKSHOP ON PLANT ADAPTATION TO MINERAL STRESS IN PROBLEM SOILS, Beltsville, 1976. Plant adaptation to mineral stress in problem soils. Beltsville: Cornell University Press, 1976. p. 255-268.

FOY, C.D. The physiology of plant adaptation to mineral stress. Iowa State Journal Research, v.57, p.355-91, 1983.

FOY, C.D. Plant adaptation to acid, aluminum-toxic soils. Communications in Soil Science and Plant Analysis, v.19, p.959-87, 1988.

FOY, C.D. Soil chemical factors limiting plant root growth. In: HATFIELD, J.L.; STEWART, B. A. (Ed) Limitations to plant root growth. New York: Springer Verlag, 1992. p. 97-149.

FOY, C.D.; FLEMING, A . L. The physiology of plant tolerance to excess available aluminum and manganese in acid soils. In: JUNG, G. A . (Ed) Crop tolerance to suboptimal land conditions. Madison: ASA, 1978. p.301-328.

FOY, C.D.; FLEMING, A . L. Aluminum tolerance of two wheat genotypes related to nitrate reductase activities. Journal of Plant Nutrition, v.5, p.1313-1333, 1982.

FOY, C.D.; BORNS, G.R.; BROW, J.C. Differential aluminum tolerance of two wheat varieties associated with plant induced $\mathrm{pH}$ changes ground their roots. Soil Science Society of America Proceedings, v.29, p.64-7, 1965. 
FOY, C.D.; FLEMING, A.L.; BURNS, G.R. et al. Caracterization of differential aluminum tolerance among varieties of wheat and barley. Soil Science Society of America Proceedings, v.31, p.513-21, 1967

FOY, C.D.; FLEMING, A . L.; ARMIGER, W.H. Aluminum tolerance of soybean varieties in relation to calcium nutrition. Agronomy Journal, v.61, p.505-511, 1969.

FOY, C.D.; CHANEY, R.L.; WHITE, M.C. The physiology of metal toxicity in plants. Annual Review of Plant Physiology, v.29, p.511- 66, 1978.

FURLANI, A . M. C.; FURLANI, P. R. Composição e pH de soluções nutritivas para estudos fisiológicos e seleção de plantas em condições nutricionais adversas. Campinas: Instituto Agronômico, 1988. 34p. (Boletim Técnico, 121).

FURLANI, P.R. Efeitos fisiológicos do alumínio em plantas. In: SIMPOSIO AVANÇADO DE SOLOS E NUTRIÇÃO DE PLANTAS, 2., Piracicaba, 1989. Anais... Campinas: Fundação Cargill, 1989. p.73-87.

FURLANI, P.R.; CLARK, R.B. Screening sorghum for aluminum tolerance in nutrient solution. Agronomy Journal, v.73, p.587-594, 1981.

FURLANI, P. R.; FURLANI, A . M. C. Tolerância a alumínio e eficiência a fósforo em milho e arroz: características independentes. Bragantia, v.50, p.331-340, 1991.

GALLAGHER, L. W., SOLIMAN, K. M.; QUALSET, R. C.; HUFFAKER, C. O; RAINS, D. W. Major gene control of nitrate reductase activity in common wheat. Crop Science, v.20, p.717-721, 1980.

GASSMANN, W.; SCHROEDER, J. I. Inward-rectifying K+ channels in root hairs of wheat. A mechanism for aluminum-sensitive low affinity $\mathrm{K}+$ uptake. Plant Physiology, v.105, p.1399-1408, 1994. 
GONÇALVES, J. F. C.; CAMBRAIA, J.; SANT'ANNA, R.; PACHECO, S. Aluminum and zinc effects on the metabolism of ribonucleic acid in two sorghum cultivars. Revista Brasileira de Fisiologia Vegetal, v.8, p.81-86, 1996.

GRIMME, H. Aluminum induced magnesium deficiency in oats. Zeitscrift fuer Pflanzenernaehrung Bodenkunde, v. 146, p.666-676, 1983.

GUSS, A ; AGOSTINI, J.A .E. Sistema de produção de leite. Vitória: EMCAPA, 1984. 18 p. (Circular Técnica, 8).

HAIRIAH, K.; VAN NOORDWWIJK, M.; STULEN, I.; MEIJBOOM, F. W.; KUIPER, P. J. C. Phosphate nutrition effects on aluminium avoidance of Mucuna pruriens var. Utilis. Enviromental and Experimental Botany, v.33, p.75-83, 1993 .

HAIRIAH, K.; STULEN, I.; VAN NOORDWWIJK, M. ; KUIPER, P. J. C. Al avoidance and $\mathrm{Al}$ tolerance of Mucuna pruriens var. Utilis: effects of a heterogeneous root environment and nitrogen form in the root environment. Plant and Soil, v.167, p.67-72, 1994.

HARIDASAN, M. Aluminium accumulation by some cerrado native species of Central Brazil. Plant and Soil, v.65, p. 265-273, 1982.

HARTWELL, B.L.; PEMBER, F.R. The presence of aluminum as a reason for the difference in the effect of so-called acid soil on barley and rye. Soil Science, v.6, p.259-81, 1918.

HAUG, A .; VITORELLO, V. Aluminum coordination to calmodulin: thermodinamic and kinetic aspects. Coordination Chemistry Reviews. 1996a. (in press).

HAUG, A .; VITORELLO, V. Cellular aspects of aluminum toxicity in plants. In: YASUI, M.; OTA, K.; STRONG, M. J.; VERITY, M. A . (Ed.) Mineral and metal neurotoxicology. Boca Raton: CRC Press, 1996b. p.35-41. 
HAUG, A .; SHI, B.; VITORELLO, V. Aluminum interaction with phosphoinositide-associated signal transduction. Archives of Toxicology, v.68, p.1-7, 1994.

HECHT-BUCHHOLZ, C.; SCHUSTER, J. Responses of Al-tolerant dayton and Al-sensitive Kearney barley cultivars to calcium and magnesium during $\mathrm{Al}$ stress. Plant and Soil, v.99, p.47-61, 1987.

HELYAR, K. R. Effect of aluminum and manganese toxicity on legume growth. In: ANDREW, C.S.; KAMPRATH, E. J. (Ed.) Mineral nutrition of legumes: tropical and subtropical soils. Melbourne: CSIRO, 1978. P.207231.

HOARAO, J.; NATO, A .; LAVERGUE, D.; FLIPO, V.; HIREL, B. Nitrate reductase activity changes during a culture cycle of tabaco cells: The participation of a membrane-bound form enzymes. Plant Science, v. 79, p.193-204, 1991.

HODDINOTT, J.L.; RICHTER, C.L. The influence of aluminum on photosynthesis and translocation in French bean. Journal of Plant Nutrition, v. 10, p.443-54, 1987.

HODSON, M. J.; WILKINS, D. A . Localization of aluminium in roots of Norway spruce (Picea abies L. Karst) inoculated with Paxillus involutos. New Phytologist, v.118, p.273-278, 1991.

HORST, W. J.; PÜSCHEL, A . K.; SCHMOHL, N. Induction of callose formation is a sensitive marker for genotypic aluminium sensitivity in maize. Plant and Soil, v.192, p.23-30, 1997.

HUANG, J.; BACHELARD, E. P. Effects of aluminum on growth and cation uptake in seedlings of Eucalyptus mannifera and Pinus radiata. Plant and Soil, v.149, p.121-127, 1993. 
HUANG, J. W.; GRUNES, D. L. Potassium/magnesium ratio effects on aluminum tolerance and mineral composition of wheat forage. Agronomy Journal, v.84, p.643-650, 1992.

HUANG, J. W.; GRUNES, D. L.; KOCHIAN, L.V. Aluminum effects on the kinetics of calcium uptake into cells of the wheat root apex. Quantification of calcium fluxes using a calcium-selective vibrating microelectrode. Planta, v. 188, p. $414-421,1992$.

HUANG, J. W.; GRUNES, D. L.; KOCHIAN, L.V. Aluminum effects on calcium uptake and translocation in wheat forages. Agronomy Journal, v.85, p.867873, 1993.

HUCK, M. G. Impairment of sucrose utilization for cell wall formation in the roots of aluminun damaged cotton seedlings. Plant and Cell Physiology, v.13, p.7-14,1972.

HUTTON, E.M.; SOUSA, F.B. Melhoramento de Panicum maximum para latossolos ácidos e de baixa fertilidade. In: REUNIÃO ANUAL DA SOCIEDADE BRASILEIRA DE ZOOTECNIA, 24, Brasília, 1987. Anais... Brasilia, SBZ, 1987. p.231.

IZ - INSTITUTO DE ZOOTECNLA Capim Aruana (Panicum maximum cv. Aruana IZ-5). Pré-lançamento. Nova Odessa, 1989. Folheto. JACOB-NETO, J.; RAVEN, J. A .; WOLLENWEBER, B. The influence of aluminium and nitrogen nutrition on ionic balance of Phaseolus vulgaris $\mathrm{L}$. cultivars. In: MONIZ, A . C.; FURLANI, A . M. C.; SCHAFFERT, R. E.; FAGERIA, N. K.; ROSOLEM, C. A .; CANTARELLA, H. In:

INTERNATIONAL SYMPOSIUM ON PLANT-SOIL INTERACTIONS AT LOW pH, Belo Horizonte, Minas Gerais, 1996. Plant-Soil Interactions at Low pH: Sustainable Agriculture and Forestry Production, Campinas: Brazilian Soil Science Society, 1997. p.252. 
JANK, L. Potencial do gênero Panicum. In: SIMPÓSIO BRASILEIRO DE FORRAGEIRAS E PASTAGENS, 1., Campinas, 1994. Anais... Campinas, Colégio Brasileiro de Nutrição Animal, 1994. p.25-31.

JANK, L. Melhoramento e seleção de variedades de Panicum maximum. In: SIMPÓSIO SOBRE MANEJO DA PASTAGEM, 12, Piracicaba. 1995. Anais... Piracicaba: FEALQ, 1995. p.21-58.

JARVIS, S. C.; HATCH, D. J. Differential effects of low concentrations of aluminum on the growth of four genotypes of white clover. Plant and Soil, v.99, p.241-253, 1987.

JOHNSON, R.R. \& JACKSON, W.A. Calcium uptake and transport by wheat seedlings as affect by aluminum. Soil Science Society of America Proceedings, v.28, p.381-6, 1964.

JONES, D. L.; KOCHIAN, L. V. Aluminum inhibition of the inositol 1,4,5triphosphate signal transduction pathway in wheat roots: a role in aluminum toxicity? Plant and Cell, v.7, p. 1913-1922, 1995.

JONES, L.H. Aluminum uptake and toxicity in plants. Plant and Soil, v.13, p.292-310, 1961.

JUMA, R. B.; TABATABAI, D. Differential phosphorus uptake by phosphorus stressed com inbreds. Crop Science, v.30, p.505-508, 1988.

KAMPRATH, E. J. Exchangeable aluminum as a criterion for liming leached mineral soils. Soil Science Society American Proceedings, v. 34, p.252254, 1967.

KAUSS, H. Some aspects of calcium-dependent regulation in plant metabolism. Annual review of Plant Physiology, v.38, p. 47-72, 1987.

KINRAIDE, T.B. Identity of the rhizotoxic aluminum species. Plant and Soil, v. 134, p. $167-178,1991$. 
KINRAIDE, T. B. Aluminum enhancement of plant growth in acid rooting media. A case of reciprocal alleviation of toxicity by two toxic cations. Physiologia Plantarum, v.88, p. 619-625, 1993.

KINRAIDE, T.B. Reconsidering the rhizotoxic of hydroxyl, sulphate, and fluoride complexes of aluminum Journal of Experimental Botany, v.48, p. 1115-1124, 1997.

KINRAIDE, T.B.; PARKER, D.R. Cation amelioration of aluminum toxicity in wheat. Plant Physiology, v.83, p.546-51, 1987.

KINRAIDE, T. B.; PARKER, D. R. Apparent phytotoxicity of mononuclear hydroxy-aluminium to four dicotyledonous species. Physiologia Plantarum, v.79, p. 283-288, 1990.

KLOTZ, F.; HORST, W. J. Effect of ammonium and nitrate-nitrogen nutrition of aluminium tolerance of soybean (Glycine max L.). Plant and Soil, v.111, p.59-65, 1988.

KOCHIAN, L.V. Cellular mechanisms of aluminum toxicity and resistance in plants. Annual review of Plant Physiology and Plant Molecular Biology, v.46, p. 237-260, 1995.

KONZAK, C. F.; POLLE, E.; KITTRICK, J. A . Screening several crops for aluminum tolerance. In: WRIGHT, M.J.; FERRARI, S.A (Ed.) WORKSHOP ON PLANT ADAPTATION TO MINERAL STRESS IN PROBLEM SOILS, Beltsville, 1976. Plant adaptation to mineral stress in problem soils. Beltsville: Cornell University Press, 1976. p.311-327.

LAFEVER, H. N.; CAMPBELL, L.C.; FOY, C.D. Differential response of wheat cultivars to Al. Agronomy Journal, v. 69, p.563-568, 1978.

LANCE, J.C.; PEARSON, R.N. Effect of low concentrations of aluminum on growth and water and nutrient uptake by cotton roots. Soil Science Society of America Proceedings, v.33, p.95-8, 1969. 
LAZOF, D. B.; RINCÓN, M.; RUFTY, T. W.; MACKOWN, C. T.; CARTER, T.

E. Aluminum accumulation and associated effects on 15 NO3-influx in roots of two soybean genotypes differing in Al tolerance. Plant and Soil, v.164, p.291-297, 1994.

LEE, C. R. Influence of aluminum on plant growth and tuber yield of potatoes. Agronomy Journal, v.63, p.363-364, 1971.

LEE, E.H.; FOY, C.D. Aluminum tolerances of two snapbean cultivars related to organic acid content evaluated by high-performance liquid chromatography. Journal of Plant Physiology, v.9, p.1481-98, 1986.

LEHNINGER, A ; NELSON, D.L.; COX, M.M. Princípios de bioquímica. 2 ed. São Paulo: Sarvier, 1995. 839 p.

LINDBERG, $\mathrm{S}$. Aluminum interacts with $\mathrm{K}+(86 \mathrm{Rb})$ and $45 \mathrm{Ca} 2+$ fluxes in three cultivars of sugar beet (Beta vulgaris). Physiologia Plantarum, v. 79, p.275-282, 1990 .

LINDBERG, S.; STRID, H. Aluminium induces rapid changes in citosolic $\mathrm{pH}$ and free calcium and potassium concentrations in root protoplasts of wheat (Triticum aestivum). Physiologia Plantarum, v. 99, p.405-414, 1997.

LINE, J. Aluminum and acid soils. Journal of Agricultural Science, v.16, p.335-64, 1926.

LLUNGANY, M.; POSCHENRIEDER, C.; BARCELÓ, J. Monitoring of aluminium-induced inhibitionof root elongation in four maize cultivars differing in tolerance to aluminium and proton toxicity. Physiologia Plantarum, v. 93, p.265-271, 1994.

LODOÑO, M.E. A .; ARISTIZÁBAL, G.V. Toxicidad de aluminio en plantas de café. Cenicafé, v.34, p.61-94, 1983.

LOPES, A S. Solos sob "cerrado": características, propriedades e manejo. 2 ed. Piracicaba: Potafos, 1984. 162p. 
LUKASZEWSKI, K. M.; BLEVINS, D. G. Root growth inhibition in borondeficient or aluminum-stressed squash may be a result of impaired ascorbate metabolism. Plant Physiology, v.112, p.1135-1140, 1996.

MA, F. J.; ZHENG, S. J.; LI, X. F.; TAKEDA, K.; MATSUMOTO, H. A rapid hydroponic screening for aluminium tolerance in barley. Plant and Soil, v.191, p. 133-137, 1997.

MAGISTAD, O.C. The aluminum content of the soil solution and its relation to soil reaction and plant growth. Soil Science, v.20, p.181-227, 1925.

MALAVOLTA, E.; KLIEMANN, H.J. Desordens nutricionais no cerrado. Piracicaba: Potafos, 1985. $136 \mathrm{p}$.

MARSCHNER, H. Mineral nutrition of higher plants. 3 ed. London: Academic Press, 1995. 889 p.

MARTIN, R. B. Citrate binding of $\mathrm{Al}^{3+}$ and $\mathrm{Fe}^{3+}$. Journal Inorganic Biochemistry, v.28, p.181, 1988.

MATSUMOTO, H.; HIRASAWA, E.; TORIKAI, H. et al. Localization of absorbed aluminum in pea root and its binding to nucleis acids. Plant and Cell Physiology, v.17, p.127-37, 1976.

Mc CAIN, S.; DAVIES, M. S. The influence of background solution on root responses to aluminium in Holcus lanatus L. Plant and Soil, v. 73, p.425$430,1983$.

Mc COSKER, T. H.; TEITZEL, J. K. A review of guinea grass (Panicum maximum) for the wet tropics of Australia. Tropical Grasslands, v.9, p.177190, 1975.

Mc CORMICK, L.H.; BORDEN, F.Y. The occurrence of aluminum-phosphate precipitate in plant roots. Soil Science Society of America Proceedings, v.38, p.931-9, 1974. 
MCLACHLAN, K.D. Comparative phosphorus in plants to a range of available phosphorus situations. Australian Journal of Agriculture Research, v.27, p.323-341, 1976.

McLACHLAN, K.D. Leaf acid phosphatase activity and the phosphorus status of field grown wheat. Australian Journal of Agricultural Research, v.33, p.453-64, 1982.

McLACHLAN, K.D. ; DE MARCO, D. G. Acid phosphatase activity of intact roots and phosphorus nutrition in plants. III. Its relation to phosphorus garnering by wheat and comparation with leaf activity as measure of phophorus status. Australian Journal of Agricultural Research, v.33, p.1$11,1982$.

MENGEL, K.; KIRKBY, E. A Principles of plant nutrition. 4 ed. Bern: International Potash Institute, 1987. 687p.

MIYASAKA, S. C.; BUTA, J.G.; HOWEL, R. K.; FOY, C. D. Mechanism of aluminum tolerance in snapbeans: Root exudation of citric acid. Plant Physiology, v. 96, p.737-743, 1991.

MOORE, D. P.; KRONSTAD, W.E.; METZGER, R.J. Screening wheat for aluminum tolerance. In: WRIGHT, M.J.; FERRARI, S.A (Ed.) WORKSHOP ON PLANT ADAPTATION TO MINERAL STRESS IN PROBLEM SOILS, Beltsville, 1976. Plant adaptation to mineral stress in problem soils. Beltsville: Cornell University Press, 1976. p. 287-295. MOUSTAKAS, M.; OUZOUNIDOU, G.; LANNOYE, R. Aluminum effects on photosynthesis and elemental uptake in an aluminum-tolerant and nontolerant wheat cultivar. Journal of Plant Nutrition, v.18, p. 669-683, 1995. MUGWIRA, L.M.; ELGAWARY; S.M.; PATEL, K.I. Differential tolerance of triticale, wheat, rye and barley to aluminum in nutrient solution. Agronomy Journal, v.68, p.782-7, 1976. 
MULDER, E.G.; BOXMA, R.; VAN VEEN, W.L. The effect of molybdenum and nitrogen deficiencies on nitrate reduction in plant tissues. Plant and Soil, v.10, p.335-55, 1959.

OSMOND, C. B.; BJÖRKMAN, O ., ANDERSON, D. J. Physiological processes in plant ecology. New York: Springer Verlag, 1980. p.61.

OTSUKA, K. Aluminum induced iron clorosis. IV - Aluminum and manganese toxicities for plants. Soil Science Plant Nutrition, v.16, p. 140-141, 1970. PARENTONI, S. N.; BAHIA FILHO, A . F. C.; GAMA, E. E. G.; LOPES, M. A; GUIMARÃES, P. E. O .; SANTOS, M. X. Diallel analysis in acid and fertile soils of maize inbred lines differing in their levels of aluminum tolerance and phosphorus efficiency. In: MONIZ, A . C.; FURLANI, A . M. C.; SCHAFFERT, R. E.; FAGERIA, N. K.; ROSOLEM, C. A .; CANTARELLA, H. In: INTERNATIONAL SYMPOSIUM ON PLANTSOIL INTERACTIONS AT LOW pH, Belo Horizonte, Minas Gerais, 1996. Plant-Soil Interactions at Low pH: Sustainable Agriculture and Forestry Production, Campinas: Brazilian Soil Science Society, 1997. p.230.

PARKER, D.R.; KINRAIDE, T.B.; ZELAZNY, L.W. Aluminum speciation and phytotoxicity in dilute hidroxy-aluminum solutions. Soil Science Society of America Journal, v.52, p.438-44, 1988.

PARKER, D.R.; KINRAIDE, T.B.; ZELAZNY, L.W. On the phytotoxicity of polynuclear hidroxy-aluminum complexes. Soil Science Society of America Journal, v.53, p.789-796, 1989.

PAVAN, M.A.; BINGHAM, F.T. Toxidez de alumínio em cafeeiros cultivados em solução nutritiva. Pesquisa Agropecuária Brasileira, v.17, p.1293-1302, 1982. 
PELLET, D.M.; PAPERNIK, L. A .; KOCHIAN, L. V. Multiple aluminumresistance mechanisms in wheat. Roles of root apical phosphate and malate exudation. Plant Physiology, v.112, p.591-597, 1996.

PETERSON, S.; STRID, H. Effects of aluminum on growth and kinetics of K+ (86Rb) uptake in two cultivars of wheat (Triricum aestivum) with different sensitivity to aluminium. Physiologia Plantarum, v.76, p.225-261, 1989.

PFEFFER, P.E.; TU, S.I.; GERASIMOWSCZ, W.V.; et al. Effects of aluminum on the release and or immobilization of soluble phosphate in com root tissue. Planta, v.172, p.200-208, 1987.

PINTRO, J.; BARLOY, J.; FALLAVIER, P. Aluminium toxicity in corn plants cultivated in a low ionic strenght nutrient solution. II. Distribution of $\mathrm{Al}$ in the principal root tip zone. Revista Brasileira de Fisiologia Vegetal, v.7, p.129-134, 1995.

PINTRO, J.; BARLOY, J.; FALLAVIER, P. Possível mecanismo de toleerância do milho através da detoxicação interna do alumínio pelos ácidos orgânicos. In: CONGRESSO LATINO-AMERICANO DE CIÊNCIA DO SOLO, 13., Águas de Lindóia, 1996. SOLO-SUELO 96. Trabalhos (compact discSONOPRESS). Piracicaba. SBCS/SLCS, 1996.

PITTA, G. V. E.; BALIGAR, V. C.; FOSTER, J. Interaction of potassium and aluminium on the exudation of organic acids by sorghum. In: MONIZ, A . C.; FURLANI, A . M. C.; SCHAFFERT, R. E.; FAGERIA, N. K.; ROSOLEM, C. A .; CANTARELLA, H. In: INTERNATIONAL SYMPOSIUM ON PLANT-SOIL INTERACTIONS AT LOW pH, Belo Horizonte, Minas Gerais, 1996. Plant-Soil Interactions at Low pH: Sustainable Agriculture and Forestry Production, Campinas: Brazilian Soil Science Society, 1997. p.261. 
POLLE, E.; KONZAK, C.F.; KITTRICK, J.A Visual detection of aluminum tolerance levels in wheat by hematoxylin staining of seedling roots. Crop Science, v.18, p. 823-827, 1978.

PRIMAVESI, A.C.P.A.; MALAVOLTA, E.; PRIMAVESI, O. Toxidez de alumínio e manganês em sorgo sacarino (Sorghum bicolor L. MOENCH). III. Relações entre P, Mg e Al. Anais da Escola Superior de Agricultura "Luiz de Queiroz", v.44, p.643-55, 1987.

RAIJ, B. V. Fertilidade do solo e adubação. Piracicaba: Ceres/Potafos, 1991. $343 \mathrm{p}$.

RANDALL, P.J.; VOSE, P.B. Effect of aluminum on the uptake and translocation of phosphorus by perennial ryegrass. Plant Physiology, v.38, p.403-9, 1963.

RAO, D.; OAKS, A .; HIREL, B. Nitrogen metabolism in roots. Plant Physiology, v.52, 345-355, 1977.

RATTER, J. A .; RIBEIRO, J. F. Biodiversity of the flora of the Cerrado. In: SIMPÓSIO SOBRE O CERRADO, 8., 1996, Brasília. Anais... Brasília, 1996. p. 3-5.

REID, D.A . Genetic potential for solving problems of soil mineral stress: aluminum and manganese toxicities in the cereal grains. In: WRIGHT, M.J.; FERRARI, S.A (ED.) WORKSHOP ON PLANT ADAPTATION TO MINERAL STRESS IN PROBLEM SOILS, Beltsville, 1976. Plant adaptation to mineral stress in problem soils. Beltsville: Cornell University Press, 1976. p. 22-23.

REID, D.A.; BIELESK, R.L. Phosphatase pools, phosphate transport and phosphate availability. Annual Review of Plant Physiology, v. 21, p.225$252,1970$. 
RENGEL, Z. Disturbance of cell $\mathrm{Ca} 2+$ homeostasis as a primary trigger of $\mathrm{A} 1$ toxicity syndrome. Plant Cell Enviromental, v.15, p.931-938, 1992.

RENGEL, Z; ROBINSON, D. L. Aluminum effects on micronutrient uptake by annual ryegrass. Communications in Soil Science and Plant Analysis, v.20, p.253-269, 1989.

RHUE, R. D.; GROGAN, C. O; MEYER, E.W.; EVERETT, H. L. Genetic control of aluminum tolerance in corn. Crop Science, v.8, p.1063-1067, 1978.

RHUE, R. D.; GROGAN, C. O Screening corn for aluminum tolerance. In: WRIGHT, M.J.; FERRARI, S.A (ED.) WORKSHOP ON PLANT ADAPTATION TO MINERAL STRESS IN PROBLEM SOILS, Beltsville, 1976. Plant adaptation to mineral stress in problem soils. Beltsville: Cornell University Press, 1976. p. 297-310.

ROCHE, R.; MENÉNDEZ, J.; HERNANDEZ, J.E. Caracteristicas morfologicas indispensables para la classificación de espécies del genero Brachiaria. Pastos y Forrages, v.13, p.205-222, 1990.

ROY, A.K.; SHARMA, A.; TALUKDER, G. Some aspects of aluminum toxicity in plants. Botanical Review, v.54, p.145-78, 1988.

RYAN, P. R.; KOCHIAN, L. V. Interaction between aluminum toxicity and calcium uptake at the root apex in near-isogenic lines of wheat (Triticum aestivum L.) differing in aluminum tolerance. Plant Physiology, v. 102, p. 975-982, 1993.

RYAN, P. R.; DiTOMASO, J. M.; KOCHIAN, L. V. Aluminum toxicity in roots: na investigation of spatial sensitivity and the role of the root cap. Journal Experimental of Botany, v.44, p.437-446, 1993. 
RYAN, P. R.; KINRAIDE, T. B.; KOCHIAN, L. V. $\mathrm{Al}^{3+}-\mathrm{Ca}^{2+}$ in aluminum rhizotoxicity. I. Inhibition of root growth is not caused by reduction of calcium uptake. Planta, v.192, p.98-103, 1994.

RYAN, P.R.; DELHAIZE, E.; RANDALL, P.J. Caracterization of Al-stimulated malate efflux from the root apices of Al-tolerant genotypes of wheat. Planta, v. 194, p.103-112, 1995.

SAMPSON, M.; CLARKSON, D.T.; DAVIES, D.D. DNA synthesis in aluminum-roots of barley. Science, v.148, p.1476-7, 1965.

SANTORO, L. G.; SOARES, T. E.; MAGALHÃES, A . C. Effects of aluminum on nitrate reduction in Zea mays L. Phyton, v.44, p.75-80, 1984.

SARKUNAN, V.; BIDDAPPA, C.C.; NAYAK, S.R. Physiology of aluminum toxicity in rice. Current Science, v.53, p. 822-4, 1984.

SARRUGE, J.R.; HAAG, H.P. Análises químicas em plantas.

Piracicaba:Escola Superior de Agricultura “Luiz de Queiroz", 1974. 56p. SAS INSTITUTE INCORPORATION. The SAS-System for Windows release

6.11 (software). Cary, North Carolina: SAS Institute Incorporation, 1996. SASAKI, M.; KASAI, M.; YAMAMOTO, Y; MATSUMOTO, H. Comparison of the early response to aluminum stress between tolerant and sensitive wheat cultivars:root growth, aluminum content and efflux of $\mathrm{K}^{+}$. Journal of Plant Nutrition, v.17, p. 1275-1288, 1994.

SASAKI, M.; YAMAMOTO, Y; MATSUMOTO, H. Lignin deposition induced by aluminum in wheat (Triticum aestivum) roots. Physiologia Plantarum, v.96, p.193-198, 1996.

SAVIDAN, Y. H.; JANK, L.; COSTA, J.C.G. Registro de 25 acessos selecionados de Panicum maximum. Campo Grande:EMBRAPA-CNPGC, 1990. 68p. 
SCHAEFFER, H. J.; WALTON, J. D. Aluminum ions induce oat protoplasts to produce an extracellular (1-3) $\beta$-D-glucan. Plant Physiology, v.94, p. 13$19,1990$.

SHRIVER, G. Inorganic Chemistry. 2 ed. New York: Springer Verlag, 1990. 687 p.

SHUMAN, L. M.; WILSON, D. O .; DUNCAN, R. R. Screening wheat and sorghum cultivars for aluminum sensitivity at low aluminum levels. Journal of Plant Nutrition, v.16, p.2383-2395, 1993.

SIEGEL, N.; HAUG, A. Calmodulin-dependent formation of membrane potential in barley root plasma membrane vesicles: a biochemical model of aluminum toxicity in plants. Physiologia Plantarum, v.59, p.285-91, 1983.

SILVA, A . A . Parâmetros biométricos e fisiológicos do crescimento de plantas de arroz (Oryza sativa) cv. Rio Paranaíba submetidos a níveis de alumínio em cultivo hidropônico. Botucatu, 1992, 158p. Tese (Mestrado) - Instituto de Biociências, Universidade Estadual Paulista “Julio de Mesquita Filho".

SILVA, N. Genetic potential for solving problems of soil mineral stress:

aluminum toxicity in wheat. In: WRIGHT, M.J.; FERRARI, S.A (ED.) WORKSHOP ON PLANT ADAPTATION TO MINERAL STRESS IN PROBLEM SOILS, Beltsville, 1976. Plant adaptation to mineral stress in problem soils. Beltsville: Cornell University Press, 1976. p. 24-30.

SIMÃO NETO, M.; SERRÃO, E. A . S.; GONÇALVES, C. A .; PIMENTEL, D.

\section{Comportamento de gramíneas forrageiras na região de Belém.}

Belém:IPEAN, 1973. 17p. (Circular Técnica, 44).

SIQUEIRA, C. Calgem para plantas forrageiras. In: MATTOS, H. B.; WERNER, J.C; YAMADA, T.; MALAVOLTA, E. Calagem e Adubação de Pastagens. Piracicaba:Associação Brasileira para Pesquisa da Potassa e do Fosfato, 1986. pp.77-91. 
SIVAGURU, M.; PALIWAL, K. Differential aluminum tolerance in some tropical rice cultivars. II. Mechanism of aluminum tolerance. Journal of Plant Nutrition, v.16, p.1717-1732, 1993.

SLASKI, J. J. Differences in the metabolic responses of root tips of wheat and ryento aluminium stress. Plant and Soil, v.167, p. 165-171, 1994.

SPAIN, J. M.; ANDREW, C. S. Mineral characterization of species. Six grass $\mathbf{x}$ four aluminum treatments in water culture. In: COMMONWEALTH SCIENTIFIC AND INDUSTRIAL RESEARCH ORGANIZATION, Sta Lucia. Annual Report 1975-1976., Commonwealth Agricultural Bureaux, 1976. 50p.

SUHAYADA, C.G.; HAUG, A. Organic acids reduce aluminum toxicity in maize root membranes. Physiologia Plantarum, v.68, p.189-95, 1986. TALEB, H. B.; LANNOYE, R.; LEDENT, J. F.; MATHIS, P. Study of the effects of aluminum toxicity and calcium deficiency on photosynthesis. In: INTERNATIONAL PHOTOSYNTHESIS CONGRESS, 10., 1995. / Resumo em CAB Abstracts on CD-ROM, 1996-95.

TAYLOR, G. H. The physiology of aluminum tolerance in higher plants.

Communications in Soil Science and Plant Analysis, v.19, p.1179-1194, 1988.

TESTER, M. Plant ions channels: whole-cell and single-channel studies. New Phytologist, v.114, p. 305-340, 1990.

THAWORNWONG, W.; VAN DIEST, A. Influence of high acidity and aluminum on the lowland rice. Plant and Soil, v. 41, p. 141-159, 1974. TISDALE, S. L.; NELSON, W. L.; BEATON, J.D. Soil fertility and fertilizers. 4 ed. New York: Macmillan Publishing Company, 1985. 754 p. 
TRUMANN, A .; TANAKA, A .; NAVASERO, S. A . Aluminum toxicity of the rice plant under culture conditions. Communications in Soil Science and Plant Analysis, v.16, p.1174-1179, 1986.

TORRES, G. A .; MARTINS, P. R.; LOPES, M. A .; PARENTONI, S. N.; PAIVA, E. Searching RFLP markers to identify genes for aluminum tolerance in maize. In: MONIZ, A . C.; FURLANI, A . M. C.; SCHAFFERT, R. E.; FAGERIA, N. K.; ROSOLEM, C. A .; CANTARELLA, H. In: INTERNATIONAL SYMPOSIUM ON PLANT-SOIL INTERACTIONS AT LOW pH, Belo Horizonte, Minas Gerais, 1996. Plant-Soil Interactions at Low pH: Sustainable Agriculture and Forestry Production, Campinas: Brazilian Soil Science Society, 1997. p.230.

USBERTI FILHO, J. A . O Agronômico, v. 34, Edição especial, 1982.

USBERTI FILHO, J. A "IAC-Centauro" novo cultivar de capim colonião de porte baixo e ciclo precoce. CONGRESSO PAULISTA DE AGRONOMIA, 6, Piracicaba, 1987. Anais...Piracicaba: FEALQ, 1987. p. 149-161.

USBERTI FILHO, J. A ; GALLO, P.B.; PEREIRA, C. A Capim colonião IACCentenário. O Agronômico, v.38, p. 121-122, 1986.

USBERTI FILHO, J. A ; FURLANI, P. R.; GALLO, P.B.; PEREIRA, C. A .; DENNUCCI, S. Avaliação de híbridos e cultivares de capim colonião (Panicum maximum Jacq.) quanto à tolerância ao alumínio. In: REUNIÃO ANUAL DA SOCIEDADE BRASILEIRA DE ZOOTECNIA, 24, Brasília, 1987. Anais... Brasília, SBZ, 1987. p.167.

VITORELLO, V. Growth-dependent aluminum uptake and discrete localization in cultured cells of Nicotiana tabacum L. cv. BY-2: a possible role for membrane traffic at the cell surface. East Lansing, 1996, 155p. Tese (Doctor of Philosophy) - Michigan State University. 
VON UEXKÜLL, H. R.; MUTERT, E. Global extent, development and economic impact of acid soils. Plant and Soil, v.171, p.1-15, 1995.

VOSE, P.B. Screening techniques for plant nutrient efficiency: philosophy and methods. In: INTERNATIONAL SYMPOSIUM ON GENETIC ASPECTS OF PLANT MINERAL NUTRITION, 3., Braunschweig, 1988. Genetics aspects of plant mineral nutrition. Dordrecht:Kluwer Academic, 1990. p.283-289.

VOSE, P. B.; RANDAL, P. J. Resistance to aluminum and manganese toxicities in plants related to variety and cation exchange capacity. Nature, v.196, p.85-86, 1962.

WHEELER, D. M. Relative aluminium tolerance of ten species of graminae. Journal of Plant Nutrition, v.18, p. 2305-2312, 1995.

WHEELER, D. M.; DODD, M. B. Effect of aluminium on yield and plant chemical concentrations of some temperate legumes. Plant and Soil, v. 173, p. 133-145, 1995.

WHEELER, D.M.; EDMEADES, D.C.; CHRISTIE, R. A Effect of aluminum on plant chemical concentrations in some temperate grasses grown in solution culture at low ionic strength. Journal of Plant Nutrition, v.15, p. 387-402, 1992.

WILKINSON, R.E.; DUNCAN, R. R. Calcium $\left({ }^{45} \mathrm{Ca}^{2+}\right)$ absorption inhibition by aluminum $\left(\mathrm{Al}^{3+}\right)$ in sorghum roots. Journal of Plant Nutrition, v. 16, p. 235 $240,1993$.

WRIGHT, K.E. The internal precipitation of phosphorus in relation to aluminum toxicity. Plant Physiology, v. 18, p.708-712, 1943.

ZAINI, Z. \& MERCADO, B.T. Phosphorus nutrition and phosphatase activity of rice seedling. I. Levels of phosphorus and phosphatase activity of the roots. Philippine Agriculturist, v.68, p. 211-216,1985a 
ZAINI, Z. \& MERCADO, B.T. Phosphorus nutrition and phosphatase activity of young rice plants grown in culture solution. II. Phosphorus-aluminum interaction and phosphatase activity of the roots. Philippine Agriculturist, v.68, p.217-224, 1985 b.

ZHANG, G.; TAYLOR, G. J. Kinetics of aluminum uptake in Triticum aestivum L.: identity of the linear phase of aluminum uptake by excised roots of aluminum-tolerant and aluminum-sensitive cultivars. Plant Physiology, v.94, p. 577-584, 1990.

ZHAO, X. J.; SUCOFF, E.; STADELMANN, E. J. $\mathrm{Al}^{3+}$ and $\mathrm{Ca}^{2+}$ alteration of membrane permeability of Quercus rubra root cortex cells. Plant Physiology, v.83, p.159-62, 1987. 